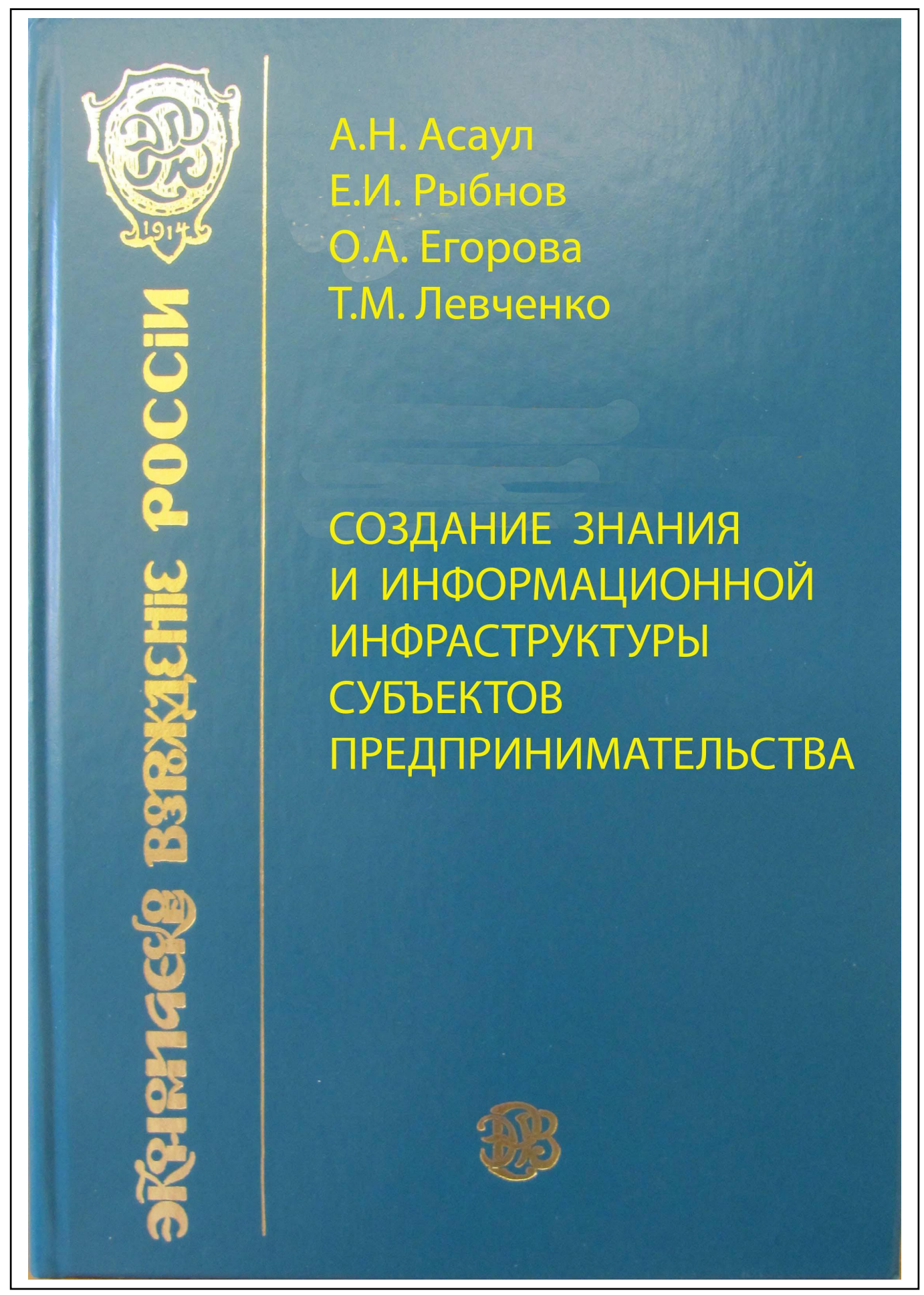


АНО Институт проблем экономического возрождения

Санкт-Петербургский государственный архитектурно-строительный университет

А. Н. АСАУЛ, Е. И. РЫБНОВ,

О. А. ЕГОРОВА, Т. М. ЛЕВЧЕНКО

\section{СОЗДАНИЕ ЗНАНИЯ И ИНФОРМАЦИОННОЙ ИНФРАСТРУКТУРЫ СУБЪЕКТОВ \\ ПРЕДПРИНИМАТЕЛЬСТВА}

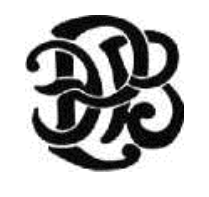

Санкт-Петербург

2010 


\section{Рецензенты:}

Л. Ф. Манаков, д-р. экон. наук, профессор (Новосибирский государственный архитектурно-строительный университет (СИБСТРИН));

E. В. Песоцкая, д-р экон. наук, профессор (Санкт-Петербургский государственный университет экономики и финансов)

Создание знания и информационной инфраструктуры субъектов предпринимательства / А. Н. Асаул, Е. И. Рыбнов, О. А. Егорова, Т. М. Левченко.; под ред. засл. Деятеля науки РФ, д.-ра экон. наук, проф. А. Н. Асаула. - СПб: АНО ИПЭВ, 2010. - 252 с.

\section{ISBN 978-5-91460-029-4}

В книге освещается феномен информации и знания, их роль в деятельности субъектов предпринимательства. Представлены классификация морфологии предпринимательских моделей хозяйствования, позволяющая проводить более подробную организационную диагностику компании; инструментарий создания и управления знаниями; модели информационной инфраструктуры субъекта предпринимательской деятельности и организационно-экономический механизм формирования системы создания и управления организационными знаниями компании.

Предназначена для научных работников, преподавателей и предпринимателей, может использоваться в учебном процессе вузов.

Издание осуществляется при поддержке

Института проблем экономического возрождения России и редакции журнала «Экономическое возрождение России».

Для контактов с авторами: asaul@yandex.ru, m. (812) 336-25-78

Серия книг издается

при редакиии журнала «Экономическое возрождение России»

Руководитель проекта главный редактор журнала, Заслуженный деятель науки РФ, доктор экон. наук, профессор А. Н. Асаул 
ОГЛАВЛЕНИЕ

\begin{tabular}{|c|c|}
\hline Введение & 5 \\
\hline Г л а в а 1. ЗНАНИЕ И ИНФОРМАЦИЯ & 6 \\
\hline 1.1. Феномен информации и ее экономическая сущность & 6 \\
\hline $\begin{array}{l}\text { 1.2. Роль информации в деятельности предпринимательских структур в } \\
\text { ретроспективном аспекте }\end{array}$ & 14 \\
\hline $\begin{array}{l}\text { 1.3. Создание организационного знания - важнейший источник } \\
\text { конкурентоспособности предпринимательской структуры }\end{array}$ & 28 \\
\hline $\begin{array}{l}\text { 1.4. Управление организационными знаниями субъектом } \\
\text { предпринимательства }\end{array}$ & 43 \\
\hline $\begin{array}{l}\text { Г Л а В а } 2 . \text { МОДЕЛИ ФОРМИРОВАНИЯ ИНФОРМАЦИОННОЙ } \\
\text { ИНФРАСТРУКТУРЫ СУБЬЕКТОВ ПРЕДПРИНИМАТЕЛЬСТВА }\end{array}$ & 55 \\
\hline $\begin{array}{l}\text { 2.1. Концепция информационной инфраструктуры субъектов } \\
\text { предпринимательской деятельности }\end{array}$ & 55 \\
\hline $\begin{array}{l}\text { 2.2.Исследование моделей информационного поля субъекта } \\
\text { предпринимательской деятельности }\end{array}$ & 71 \\
\hline $\begin{array}{l}\text { 2.3. Принципы формирования информационной инфраструктуры } \\
\text { субъекта предпринимательства }\end{array}$ & 84 \\
\hline $\begin{array}{l}\text { 2.4. Сетевая модель информационного взаимодействия субъекта } \\
\text { предпринимательства }\end{array}$ & 95 \\
\hline $\begin{array}{l}\text { Г л А В А З. МЕТОДЫ ФОРМИРОВАНИЯ СИСТЕМЫ СОЗДАНИЯ } \\
\text { И ЭФФЕКТИВНОГО УПРАВЛЕНИЯ ОРГАНИЗАЦИОННЫМ ЗНАНИЕМ } \\
\text { (ССУОЗ) В ПРЕДПРИНИМАТЕЛЬСКИХ ФОРМИРОВАНИЯХ }\end{array}$ & 105 \\
\hline $\begin{array}{l}\text { 3.1.Использование методологических принципов теории деятельности в } \\
\text { процессе создания, накопления и передачи организационного знания }\end{array}$ & 105 \\
\hline $\begin{array}{l}\text { 3.2. Классификация предпринимательских моделей хозяйствования для } \\
\text { определения подхода к созданию ССУОЗ }\end{array}$ & 118 \\
\hline $\begin{array}{l}\text { 3.3. Концепция обучающихся организаций - основа для формирования } \\
\text { инновационного процесса, обеспечивающего создание нового знания }\end{array}$ & 135 \\
\hline $\begin{array}{l}\text { Г л а В а } \text { 4. ОРГАНИЗАЦИОННО-ЭКОНОМИЧЕСКИЙ МЕХАНИЗМ } \\
\text { ФОРМИРОВАНИЯ ССУОЗ СУБЬЕКТА ПРЕДПРИНИМАТЕЛЬСТВА }\end{array}$ & 147 \\
\hline $\begin{array}{l}\text { 4.1. Эффективность управленческих решений и роль информационной } \\
\text { инфраструктуры в системе создания и эффективного управления } \\
\text { организационным знанием }\end{array}$ & 147 \\
\hline $\begin{array}{l}\text { 4.2. Методические положения по управлению информационным полем } \\
\text { организации }\end{array}$ & 159 \\
\hline $\begin{array}{l}\text { 4.3. Экономическая эффективность управления информационной } \\
\text { инфраструктурой субъекта предпринимательства }\end{array}$ & 168 \\
\hline 4.4. Алгоритм формирования информационной инфраструктуры & 177 \\
\hline Приложения & 185 \\
\hline
\end{tabular}




\section{ВВЕДЕНИЕ}

Ученые в области теорий организации и менеджмента всего мира согласны в том, что условия функционирования социально-экономических систем сегодня изменились самым коренным образом. Это и глобализация, и изменение социально-экономических отношений, и многократное усиление информационного воздействия, и другие факторы. Все это приводит к тому, что использование существующих подходов к управлению предпринимательскими структурами становится менее продуктивным. Возникает необходимость выработки новых современных инструментов управления, которые позволяли бы принимать результативные и эффективные решения в новых условиях.

Много надежд возлагалось на процессную управленческую парадигму, позволяющую за счет оптимизации системы бизнес-процессов субъектов предпринимательства добиться значительного увеличения результативности и эффективности функционирования. Однако эта управленческая парадигма может эффективно использоваться только в компаниях, где бизнес-процессы на каждом цикле существенно не изменяются, а значимость их как вклада в конечный результат велика. Область применения процессной парадигмы сузилась, что на фоне изменения условий хозяйствовании обнажило острый дефицит в инструментарии управления интеллектуальным бизнесом, в основе которого лежат процессы управления информацией и знаниями, слабо поддающимися структуризации и не являющимися циклическими. Если ранее информация рассматривалась как обеспечивающий элемент процессов управления, то в настоящее время понимается как определяющий, ключевой фактор.

К 1990-м годам накопилось достаточно теоретических разработок и практического опыта в сфере управления знаниями, чтобы можно было утверждать, сформировалась ли новая управленческая парадигма - парадигма управления знаниями. Наиболее значимым фактором, сдерживающим развитие и применение инструментария парадигмы управления знаниями, мы считаем тот факт, что не выявлены зависимости между особенностями функционирования субъекта предпринимательской деятельности того или иного типа и тем, какую роль в нем играют знания. Речь идет о задаче придания ситуационного характера концепции управления знаниями. Ситуация осложняется также тем, что отсутствуют четкие критерии оценки эффективности внедрения информационной инфраструктуры и системы создания и управления организационными знаниями (ССУОЗ). Эта сложность имеет объективную причину: результаты внедрения ССУОЗ проявляются опосредованно через улучшение значений показателей результативности и эффективности основной деятельности.

Сложившееся понимание информационной инфраструктуры как совокупность способов и процессов получения, обработки, накопления и передачи информации не в полной мере отвечает теории и принципам современного менеджмента, реалиям современного развития субъектов предпринимательской деятельности. Большинство ученых исследовало информационную инфраструктуру с позиций теории информационных технологий, не учитывая принципов современного менеджмента. Предлагаемые модели информационной инфраструктуры носят формальный характер, отражающий современные технологические возможности вычислительной техники, и не могут служить основой для формирования информационного поля системы менеджмента организации. Увлечение специалистов и ученых открывающимися возможностями компьютерных и инфокоммуникационных технологий на сегодняшний день приводит к «механистическому» подходу, к потере целевого фактора использования технологий - повышения эффективности системы менеджмента организации, «...к неоправданному упрощению и необоснованному редуцированию моделей менеджмента конкретной организации» (Rotenberg М.). Именно поэтому нам представляется актуальной задача ревизии и развития современных представлений об информационной инфраструктуре субъектов предпринимательской деятельности с позиций теории и принципов современного менеджмента. Исследование информационной инфраструктуры осуществляется как элемент системы управления хозяйственной деятельностью организации. Предложенная методика проектирования ССУОЗ учитывает как особенности используемой предпринимательской модели хозяйствования, так и дифференцированность подходов к работе с организационным знанием в подразделениях компании. 


\section{ЗНАНИЕ И ИНФОРМАЦИЯ}

\section{1. ФЕНОМЕН ИНФОРМАЦИИ И ЕЕ ЭКОНОМИЧЕСКАЯ СУЩНОСТЬ}

Развитие условий хозяйствования можно представить последовательностью следующих стадий развития общества: доаграрное общество, аграрное (до 1800-х гг.), индустриальное (1800-1960 гг.) и постиндустриальное или информационное (настоящее время). Новое общество, названное Питером Друкером «информационным обществом» (knowledge society), отличается от предшествующих формаций тем, что основную роль в нем играет знание.

Организационная структура управления предпринимательскими формированиями, т. е. современная организационная реальность в результате «постиндустриализации», характеризуется следующими чертами:

1. Процессныц пиинции построения предпринимательских формирований взамен функциональному. Процессное мылиение. Использование функционального принципа построения предпринимательских формирований было возможным и необходимым вследствие простоты и больших объемов производимой продукции: главным фактором успеха являлось снижение затрат на производство продукции, в основном, за счет использования эффекта масштаба. На современном же этапе предпринимательские формирования должны удовлетворять совсем другим требованиям: продукт -индивидуализирован, сложен, технологичен и постоянно обновляется. Это привело к необходимости использования процессного принципа построения организаций - формирование высокопрофессиональных, новаторских, мобильных команд, ориентированных на конечный результат (полное удовлетворение потребностей клиента) ${ }^{1}$.

2. Ориентированность на удовлетворение индивидуальных потребностей клиента. Увеличение количества предпринимательских структур, объемов производства в индустриальную эру привело сначала к насыщению рынков стандартными товарами, а затем к их сокращению, так как потребители стали предъявлять дополнительные требования к продукции (фрагментация структуры спроса, влекущая фрагментацию структуры предложения на рынках большинства товаров).

3. Создание и развитие предпринимательских сетей, позволяющих экономить на трансакционных издержках и полнее удовлетворять запросы потребителей. Спецификой сетевого подхода (в рамках более общего системного подхода) является интеграция отраслевых и территориальных аспектов, возможность более полного использования инфраструктурного потенциала, а также способность к изменению конфигурации сети: замене элементов, присоединению дополнительных элементов.

Объединение организаций в единую сеть осуществляется на основе вертикальных и горизонтальных взаимодействий между различными бизнессубъектами и их симбиозной взаимозависимости, определяемой принципом синергизма. Такие объединения позволяют малым и средним организациям

\footnotetext{
${ }^{1}$ Cucmeмы управления бизнес-процессами и корпоративная культура. URL: http://www.bigspb.ru
} 
комбинировать преимущества малых форм предпринимательства и крупных производств.

Одной из разновидностей современных сетевых объединений являются предпринимательские сети (ПС). Предпринимательскую сеть можно идентифицировать как группу фирм-участников того или иного рынка, объединившихся с целью эффективного использования ресурсов и специфических преимуществ для совместной реализации предпринимательских проектов. Используя преимущественно горизонтальные связи, механизмы специализации и взаимодополнения, они получают дополнительные возможности к достижению более высоких результатов.

Предпринимательская сеть объединяет сетевых партнеров -организации, которые формируют предпринимательскую стратегию на основе положений сетевого подхода и в соответствии с принципами функционирования предпринимательских сетей, являющихся их участниками. Предпринимательскую сеть (как и любое другое сетевое образование) характеризуют: единая цель; четкая внутренняя структура; высокая степень взаимосвязи структурных элементов; взаимосвязь с внешней средой.

Отличительная черта ПС - предпринимательская целеориентация. ПС всегда направлена на решение задач управления рынком на основе активизации предпринимательских инициатив, гибкости, стратегической маневренности и перманентности инноваций. В совокупности известных сетевых образований выделяются кластерные модели. Кластеры представляют собой объединения бизнес-субъектов, функционирующих в пределах четко очерченных территориальных образований.

Кластеры можно рассматривать как одну из разновидностей крупных сетей предпринимательского типа, охватывающую широкий спектр социальноэкономических аспектов. Являясь следствием территориально-отраслевого деления общественного воспроизводства, кластеры реально воплощают идеологию сетевого подхода.

Предпринимательские сети отнюдь не всегда столь масштабны. Они могут объединять представителей малого и среднего бизнеса, интегрировать деятельность малых предприятий различного профиля в сферу деятельности представителей крупного бизнеса. ПС не подвержены жесткой привязке к территориальным параметрам, они могут иметь локальный характер, а «подвижность» их масштабов позволяет обеспечивать большую гибкость, адаптивность и мобильность предпринимательской деятельности ${ }^{1}$.

4. Усиление и глобализация конкуренциии. В эпоху глобализации многие предпринимательские формирования, переходящие в стадию зрелости, ориентируют свою деятельность на глобальный рынок, предоставляющий огромные потенциальные возможности. «Новые виды продукции и услуг требуют огромных инвестиций, залогом доходности которых является освоение мирового рынка» ${ }^{2}$. Глобализация конкуренции приводит к усилению конкуренции на локальных рынках, а «глобализация компаний» превращается в новый этап жизненного

1 Асаул А. Н,, Скуматов Е. Г., Локтеева Г. Е. Методологические аспекты формирования и развития предпринимательских сетей / под ред. А. Н. Асаула. СПб.: Гуманистика, 2004.

${ }^{2}$ Каплан Р., Нортон Д. Сбалансированная система показателей. От стратегии к действию. М.: Олимп-бизнес, 2006. 
цикла предпринимательских формирований (наступающий после достижении определенного уровня зрелости).

5. Повсеместное новаторство. Усиление и глобализация конкуренции, изменение запросов покупателей приводит к существенному сокращению срока жизни продукции (периода времени от разработки до момента снятия продукта с производства) - с десяти до нескольких лет в среднем. Это приводит к возникновению инновационных организаций, которые постоянно инициируют внедрение нововведений « во всех сферах своего организационного контекста» .

В настоящее время в России создано около 50 тысяч малых инновационных организаций (МИО), но только 41 \% занимались НИОКР, проектированием нововведений, созданием и распространением программного продукта и производством наукоемкой продукции, на основе принадлежащей им интеллектуальной собственности они осваивали производство новой продукции на десятки миллиардов рублей в год, а это менее 2 \% от общего количества малых предприятий. Такое положение подтверждается и числом патентов на изобретения, выданных малым предприятиям. Так, например с 1994-го до 2003 г. отечественные малые предприятия получили примерно 1300 патентов на изобретения, что составляет менее 1 \% от общего числа действующих в настоящее время патентов РФ. Максимальное число МИО, получивших патенты (102), приходится на 1997 год ${ }^{1}$.

Распределение МИО по профилю деятельности приведено в табл. 1.1. Профиль деятельности МИО указан по описанию изобретения. Но как показали исследования, существует определенная разновидность МИО производственного назначения: одни организации могут разрабатывать новые технологии или осваивать производство новой продукции; другие призваны осваивать производство новой продукции, в том числе с использованием новых технологий. Кроме того, к примеру, в строительстве как отрасли народного хозяйства существует подотраслевые срезы: строительство объектов жилищного, промышленного, сельскохозяйственного, энергетического назначения и др.

Как видно из данных табл. 1.1, многие МИО (больше половины) не указывают в своем названии профиля деятельности.

Данные табл. 1.1 и 1.2 также свидетельствуют о достаточно большом диапазоне деятельности МИО, в котором превалируют следующие направления: научно-производственные, внедренческие и с внедренческим уклоном. По организационно-правовому статусу в общем количестве МИО 187 имеют статус автономных, далее следуют государственные, остальные распределились по другим категориям.

Таблица 1.1

Распределение МИО по профилю деятельности

\begin{tabular}{|l|c|}
\hline \multicolumn{1}{|c|}{ Профиль деятельности МИО } & $\begin{array}{l}\text { Количеств } \\
\text { о МИО }\end{array}$ \\
\hline 1. Научно-производственные & 55 \\
\hline 2. Научно-технические & 12 \\
\hline 3. Научно-внедренческие & 15 \\
\hline 4. Научно-производственные и внедренческие & 16 \\
\hline
\end{tabular}

${ }^{1}$ Корчагин А. Д., Смирнов Ю. Г. Значение и роль малого бизнеса в инновационном процессе // Инновации. 2002. № 5. 


\begin{tabular}{|l|c|}
\hline 5. Внедренческие & 23 \\
\hline 6. Научно-исследовательские, конструкторско-технологические & 11 \\
\hline 7. Инновационно-коммерческие & 5 \\
\hline 8. Многопрофильные & 6 \\
\hline 9. Медицинские & 9 \\
\hline 10. Без указания профиля & 146 \\
\hline
\end{tabular}

Таблица 1.2

Распределение МИО по организационно-правовому статусу

\begin{tabular}{|l|l|}
\hline Организационно-правовой статус МП & Количество \\
\hline Автономные (унитарные) & 187 \\
\hline Государственные & 43 \\
\hline В форме АО, НРО, НИИ, ТОО, ООО и др. & 24 \\
\hline При АО, НПО, НИИ, вузах и других & 17 \\
\hline При федеральных центрах & 2 \\
\hline Коллективные & 4 \\
\hline Индивидуально-частные & 11 \\
\hline
\end{tabular}

Созданием новой продукции в 2005-2006 гг. занималось около 57 \% российских промышленных организаций, хотя такие планы имели $82 \%$. Если спроецировать это соотношение планов и реальных действий на ближайшие годы, то разработка новых изделий в 2008 г. окажется возможной менее чем на половине российских компаний. Вряд ли такую тенденцию можно приветствовать. Поэтому нацеленность Правительства РФ на стимулирование инновационного роста российской экономики более чем обоснованна ${ }^{1}$.

6. Изменение наемных работников, влекущее изменение модели отномений между нанимателем и исполнителем. В основе происходящих в этой области изменений лежит, по нашему мнению, повышение уровня образованности населения. Это влечет за собой: а) существенное увеличение уровня квалификации большинства групп работников; б) увеличение благосостояния населения; в) кардинальные изменения превалирующей в обществе структуры потребностей и мировоззрения. Самое главное - это, наряду с распространением автоматизированного труда, приводит к независимости сотрудников. Пользуясь терминологией Ф. Герцберга, можно утверждать, что значимость гигиенических факторов сегодня ничтожна, значимость же мотиваторов многократно возросла по сравнению, например, с 1970-ми гг.

Эксперты выделяют следующие изменения в модели отношений между работодателем и наемным работником²:

1) необходимость использования демократичных стилей управления взамен авторитарным (по терминологии Курта Левина), часто полное отсутствие иерархии во взаимоотношениях между сотрудниками и руководителем;

2) расширенные «размытые» полномочия сотрудников (квалифицируемые

${ }^{1}$ Модернизация экономики на основе технологических инноваций / А. Н. Асаул и др. СПб.: АНО ИПЭВ, 2008.

${ }^{2}$ Роббинз СП., Коултер М. Менеджмент. М.: Вильяме, 2007. 
каждый раз исходя из потребностей решаемой задачи; активное участие персонала в процессах принятия решений; самоорганизация персонала);

3) увеличение мобильности рабочей силы: «нерегламентируемость» места и времени выполнения работы (возникновение виртуальных организаций и организаций «без границ», когда сложно отделить временных сотрудников от постоянных).

Таким образом, характеристики организационной реальности остались прежними - сложность и динамичность; изменились информационные процессы субъектов предпринимательства.

Научный анализ экономического содержания информационных процессов, концепции информационной инфраструктуры предпринимательской структуры необходимо начать с определения «информации». Любые составные термины (информационная инфраструктура, информационное поле, информационный процесс, информационные технологии, информационная экономика и т. п.) становятся осмысленными только в рамках определенности базовой категории. Феномен информации определяется современной наукой как философская категория. «...Нет, пожалуй, на сегодняшний день более сложного, неоднозначного и противоречивого для осмысления наукой явления, чем феномен информации. И наши достижения на пути ее использования (цитата в контексте вопроса об информационных технологиях - aвm.) скорее создают новые научные вопросы, чем формируют понимание сущности...» ${ }^{1}$.

Дискуссия о философском смысле, диалектическом содержании категории «информация» на сегодняшний день не завершена. Процесс обсуждения диалектического содержания сводится к двум точкам зрения. Первая, выраженная академиком А. Д. Урсулом ${ }^{2}$, основана на постулате о двух фундаментальных субстанциях мироздания (вещество и энергия), в рамках которых информация является семантическим кодом восприятия, создания образов субстанций. На формирование второй позиции во многом повлияли работы академика В. И. Вернадского ${ }^{3}$ о сущности ноосферы. Она трактует информацию как самостоятельный третий вид фундаментальной субстанции мироздания, наравне с энергией и материей. Данная дискуссия развивается в некоторых российских и зарубежных научных исследованиях учеными, позиция которых воспринималась автором как методологическая по отношению к объекту исследования. Среди них: В. Ф. Абдеев, Ю. Ф. Абрамов, Р. Д. Аветисян, Д. В. Аветисян, В. М. Агеев, А. К. Айламазян, Е. В. Стась, А. В. Антонов, Ф. Л. Бауэр, Г. Гооз, Л. Бриллюэн, М. Брой, А. Быховский, А. И. Величкин, И. И. Гришкин, В. И. Дмитриев, Д. И. Дубровский, А. Н. Ефимов, М. И. Жалдан, А. Н. Квитко, Н. Н. Заличев, А. О. Иезуитов, И. М. Коган, Е. В. Котова, А. Н. Колмогоров, И. В. Кузьмин, В. А. Кедрус, М. Мазур, Л. А. Петрушенко, Р. П. Полтавский, А. Д. Урсул, Е. А. Седов, Р. Л. Стратонович, А. П. Суханов, В. С. Тюхтин, Д. С. Чернавский, И. И. Юзвишин, А. М. Яглом, М. Янков, К. Шеннон. Несмотря на научный интерес ко второй парадигме (информация как самостоятельная субстанция мироздания) современные теоретические и

1 Activity-based relationships among management information systems and service organization revenues / Albright T. L. et al. A Markov process. Advances in Management Accounting (6). 1998.

${ }^{2}$ Урсул А Д. Природа информации. М.: Политиздат, 1968.

3 Карако П. С. Философия и методология науки: В. И. Вернадский. Учение о биосфере. Мн.: Экоперспектива, 2007. 
прикладные знания (в том числе и исследуемая концепция информационной инфраструктуры) развиваются в рамках понимания информации как семантического кода материи и энергии (первая точка зрения). Достижения науки в области кибернетики и информационных технологий, вошедшие в современную жизнь, опираются именно на понимание информации как универсального свойства материи, считая «... достаточным уровень развития парадигмы информации как кода описания объектов для реализации научных исследований и решения прикладных задач» ${ }^{1}$. Именно поэтому в качестве методологического базиса исследования принята доминирующая в современной науке диалектическая позиция об информации как «...универсальном свойстве материи, представляющем собой распространение в пространстве и времени содержания объектов (явлений) действительности посредством объективно существующих носителей различной природы» ${ }^{2}$.

Современный консолидированный диалектический взгляд на информацию может быть выражен через три признака категории информации ${ }^{3}$ :

1) проявление в передаче, то есть может быть определено процессами формирования, трансляции, получения;

2) реализация в сообщении, имеет формализованную семантическую форму;

3) качественные и количественные характеристики, объективность и измеримость в контексте использования.

Лингвистическое комбинирование признаков в предметном описательном контексте (например, задач или аспектов исследования в рамках дисциплины) позволяет судить о корректности сформированного определения по отношению к принятому методологическому базису.

Переходя от методологии науки к экономической теории также можно видеть, что последняя определяет информацию как содержательную сторону описания экономических объектов, проявляемую в процессах взаимодействия институтов, субъектов и систем. Позиция соответствует как заявленному диалектическому воззрению, так и признакам явления. В рамках методологической позиции экономической теории сформированы и развиваются научные дисциплины, являющиеся теоретическим базисом исследования информационных процессов предпринимательской структуры, в частности концепции управления информационной инфраструктурой компании. В число научных дисциплин, фокусирующихся на вопросах информационных потоков и предлагающих соответствующие теоретические и методические решения, входят:

- теория современного менеджмента;

- теория экономической кибернетики;

- теория информационных технологий.

Теория современного менеджмента исследует вопросы управления информационными потоками организации с позиций реализации основных хозяйственных функций. В поле зрения теории менеджмента попадают способы и методы управления информацией, формирующие факторы конкурентоспособности, позиционной дифференциации, компетенции организации во внешней среде 4 . Теория

${ }^{1}$ Асаул А. Н. Снижение трансакционных затрат в строительстве за счет оптимизации информационного пространства. СПб.: АНО ИПЭВ, 2008.

${ }^{2}$ Урсул А. Д. Проблема информации в современной науке. М.: Наука, 1975.

${ }^{3}$ Агеев B. M. Теория информации и кодирования: дискретизация и кодирование измерительной информации. М.: МАИ, 1977.

${ }^{4}$ Друкер П. Задачи менеджмента в 21-м веке / пер. с англ. М.: Изд. Дом 
кибернетики, экономической кибернетики применительно к организации, сосредоточена на исследовании информации как элемента управленческих процессов динамической системы. Кибернетика дает научную основу осмысления связи между субъектом, объектом управления и информационным потоком, его качественных и количественных управленческих характеристик. Если теория современного менеджмента исследует «логистику информационных потоков организации» 1 , то экономическая кибернетика предлагает теорию и количественные методы синтеза информационных управленческих потоков, обеспечивающих организационную устойчивость динамических систем². Формально данные теории сближены по объекту исследования, но акцентируются на различных аспектах исследования роли информации в организации. В том числе использование теориями различного аппарата описания и исследования объекта (менеджмент - подходы институциональной экономики; кибернетика - экономико-математические методы) позволяет расширить инструментарий изучения вопроса.

Теория информационных технологий, в настоящее время имеющая междисциплинарное научное значение, исследует объективную природу информации - качественные и количественные характеристики, формирует методы обработки и интерпретации информационных потоков 3 .

К сожалению, в последнее время в науке появляются мнения ${ }^{4}$ о терминологической синонимичности и смысловой идентичности областей информационных технологий и компьютерных технологий. Здесь следует внести ясность, поскольку этот аспект является значимым в обсуждении вопроса информационной инфраструктуры. Современная наука данные теории относит к различным теоретическим и инструментальным областям знаний. Информационные технологии формировались в рамках математической теории связи (К. Шеннон), они ориентированы на формирование математических методов качественной и количественной интерпретации информации. А компьютерные технологии - это область технико-технологических знаний, относимая к использованию вычислительной техники. Конечно, данные области тесно взаимосвязаны, что и определяет складывающуюся неправомерную практику смешения их теоретического и терминологического базисов. Взаимосвязь проявляется в том, что методы информационных технологий являются основой

«Вильяме», 2000.

${ }^{1}$ Севастьянов A. A. Формирование информационной инфраструктуры рынка ценных бумаг: мировой опыт и российская практика: автореф. дис. ... канд. экон. наук: 08.00.14. M., 2003.

${ }^{2}$ Айламазян A. K., Стась E.B. Информатика и теория развития. М.: Наука, 1989.

${ }^{3}$ Советов Б. Я., Цехановский В. В. Информационные технологии. М.: Изд-во Высшая школа, 2008

4 Ершова T. Б. Развитие промышленных предприятий на основе оптимизации инвестиций в модернизацию информационно-телекоммуникационной инфраструктуры. Комсомольск-на-Амуре: Изд-во АмГПГУ, 2007; Копайгородский А. Н. Методы, модели и программные средства построения информационной инфраструктуры исследований в энергетике: автореф. дис. ... канд. техн. наук: 05.13.18. Иркутск, 2008; Полянская О.Ю., Горбатов B. С. Инфраструктуры открытых ключей: учеб. пособие. М.: Интернет-ун-т информ. технологий, 2007; Свадьбина T. В. Коммуникации в организациях: учебно-метод. пособие. Н. Новгород: Нижегородский регион, ин-т управл. и экономики АПК, 1998; Юн A. Э. Адаптивный механизм создания информационной инфраструктурыуправления таможенной деятельностью: автореф. дис. ... канд. экон. наук: 08.00.05. М., 2001. 
алгоритмов вычислительной техники. В свою очередь компьютерная техника дает возможность реализовать ряд математических методов обработки информации, которые недоступны (труднодоступны) с точки зрения «ручных» вычислений. Например, такие методы информационных технологий как фрактальный и кластерный анализ, транспортная задача, расчеты сетевых моделей и графов перешли из области единичных решений в сферу популярных методов исследования только благодаря развитию компьютерной (вычислительной) техники. Информационная инфраструктура, ее методы управления исследуются именно в плоскости информационных технологий, а компьютерные возможности рассматриваются как инструмент автоматизации предлагаемых методов и алгоритмов преобразования информационных потоков (в настоящей работе не исследуются).

Теория информационных технологий развивается параллельно с теориями экономической кибернетики и современного менеджмента. Взаимосвязь проявляется в том, что информационные технологии синтезируют методы обработки информации, используемые в системах управления организацией. Теория менеджмента в большей степени оперирует методами преобразования и взаимосвязи структуры информационных потоков ${ }^{1}$ (методы фильтрации, графы, сетевые модели), а кибернетика - методами информационных технологий, ориентированными на количественное и качественное преобразования информационного содержания ${ }^{2}$ (экономико-математические методы).

Заметим, что и определения информации, которыми оперируют данные дисциплины (табл. 1.3), имеют смысловое и лингвистическое соответствие обозначенной научной методологии и трем базовым признакам выделения категории.

Таблица 1.3

Определение информации в основных дисциплинах

\begin{tabular}{|l|l|}
\hline Теория & Определение \\
\hline Методологическая & $\begin{array}{l}\text { Универсальное свойство материи, представляющее собой } \\
\text { распространение в пространстве и времени содержания объектов } \\
\text { (явлений) действительности посредством объективно существующих } \\
\text { носителей различной природы }\end{array}$ \\
\hline $\begin{array}{l}\text { Теория } \\
\text { менеджмента }\end{array}$ & $\begin{array}{l}\text { Сведения, данные, значения экономических показателей, } \\
\text { являющиеся объектами хранения, обработки и передачи }\end{array}$ \\
\hline $\begin{array}{l}\text { Теория экономиче- } \\
\text { ской кибернетики }\end{array}$ & $\begin{array}{l}\text { Значение, приписываемое данным на основе известных соглашений, } \\
\text { относящихся к их представлению5 }\end{array}$ \\
\hline
\end{tabular}

${ }^{1}$ Мескон М. Х., Альберт М,, Хедоури Ф. Основы менеджмента / пер. с англ. М.: Дело, 2000 .

2 Ларичев О. И., Петровский $A$. В. Системы поддержки принятия решений. Современное состояние и перспективы их развития // Итоги науки и техники. Сер. Техническая кибернетика. Т. 21. М.: ВИНИТИ, 1987.

${ }^{3}$ Гришкин И. И. Понятие информации. Логико-методологический аспект. М.: Наука, 1973

4 Семенова И. И. История менеджмента: учеб. пособие для вузов. М.: ЮНИТИДАНА, 2000.

5 Toвcmblx Л. E. Информатизация бизнеса и информационные системы на 


\begin{tabular}{|l|l|l|l|}
\hline $\begin{array}{l}\text { Теория информаци- } \\
\text { онных технологий }\end{array}$ & $\begin{array}{l}\text { Сообщение, обладающее качественными и количественными } \\
\text { характеристиками, характеризующими его процесс накопления, } \\
\text { обработки, передачи }\end{array}$ \\
\hline
\end{tabular}

Методологическая определенность базовой дефиниции позволяет перейти к обсуждению вопроса об экономической сущности информации, под которой понимаем возможность описания ее в рамках базовых экономических категорий. Экономическая сущность информации выражается, в первую очередь, в объекте труда, включающем предмет (то, на что воздействует человек в процессе труда), средства (то, чем человек воздействует на предмет труда) и продукт труда, основании товарно-денежных отношений.

В настоящее время можно судить о выраженном проявлении содержания информации в рамках базовых экономических категорий. Действительно, имеет место сформировавшийся рынок информации (с общемировым среднегодовым темпом роста 27,2 \%, The World Bank Annual Report 2009²5, наличие товарноденежных отношений в рамках информации как продукта. Профессор J. S. Holtzman предлагает ввести в экономическую теорию понятие «института информации», в частности, указывая на то, что «...информация становится общественным ресурсом развития, масштабы еe использования стали сопоставимыми с традиционными (энергия, (сырье и т. д.) ресурсами» ${ }^{3}$. Информация как продукт обусловливает и понимание информации как предмета труда. Информационный продукт представляет собой результат переработки первичных сведений, данных, знаний, других форм представления информации как pecypca, предмета труда. Развитие представлений профессора J. S. Holtzman в работах M. Castells основано на тезисе о роли информации как предмета труда во всех сферах производства. «...Выпуск любой материальной продукции всегда обусловлен и разработкой новой информации (справочная документация, обучающая, руководства, инжиниринговая и патентная и т. п.), формирование которой должно рассматриваться как производство информационного продукта.... Поэтому помимо традиционного рынка коммерческой информации мы должны учитывать и объемы сопровождающей информации. Основанием для этого следует принимать факт включения данной информации в себестоимость, цену продукции... Информация становится «предметом труда» не только в традиционном информационном бизнесе, но и в любом производственном процессе...» ${ }^{4}$. То есть, информация как предмет труда, производственных отношений на сегодня не является прерогативой специализированных информационных агентств, она становится всеобщим предметом труда. «...Затраты на подготовку сопроводительной информации на изделия соразмерны с затратами на выпуск самих изделий».

современном этапе: мифы и реалии // Экономическая кибернетика: системный анализ в экономике и управлении: сб. науч. тр. Вып. № 10. СПб.: Изд-во СПбГУЭФ, 2004.

${ }^{1}$ Там же.

${ }^{2}$ The World Bank Annual Report. The IMF publishes balance of payments data in its International Financial Statistics and Balance of Payments Statistics Yearbook. World Bank, 2009.

${ }^{3}$ Holtzman J. S. et al. Market Information Systems and Services: Lessons rom the AMIS Project Experience. Abt Associates, Bethesda, Maryland, 1993.

${ }^{4}$ Castells M. The Information Age: Economy, Society and Culture: End ofMilenium. Maiden (Ma.). Oxford: Blackwell Publ., 1998. 
Информационные технологии как методы и подходы к обработке, передаче, накоплению и интерпретации информации являются очевидным средством труда. Причем средством труда, проявляемым не только в процессах формирования информационных продуктов, но и в процессах производства всех видов продукции. Трудно назвать на сегодняшний день область производственной деятельности, для которой не было бы предложено информационных технологий для повышения результативности и (или) эффективности трудового процесса.

Экономическая сущность информации не ограничена формальным соответствием экономическим категориям. Можно понимать и взаимосвязь категорий (рис. 1.1) в рамках производственных и рыночных отношений. В частности, информационные технологии являются не только средством труда, но и продуктом в товарообмене. Например, существующий рынок программного компьютерного обеспечения (материализованной формы информационных технологий) представляет собой не что иное, как рынок средств труда. А первичные сведения, данные и знания, участвующие как предмет труда в производстве информационного продукта, образуют рынок первичной информации, представленный базами данных, статистикой и другими первичными источниками.

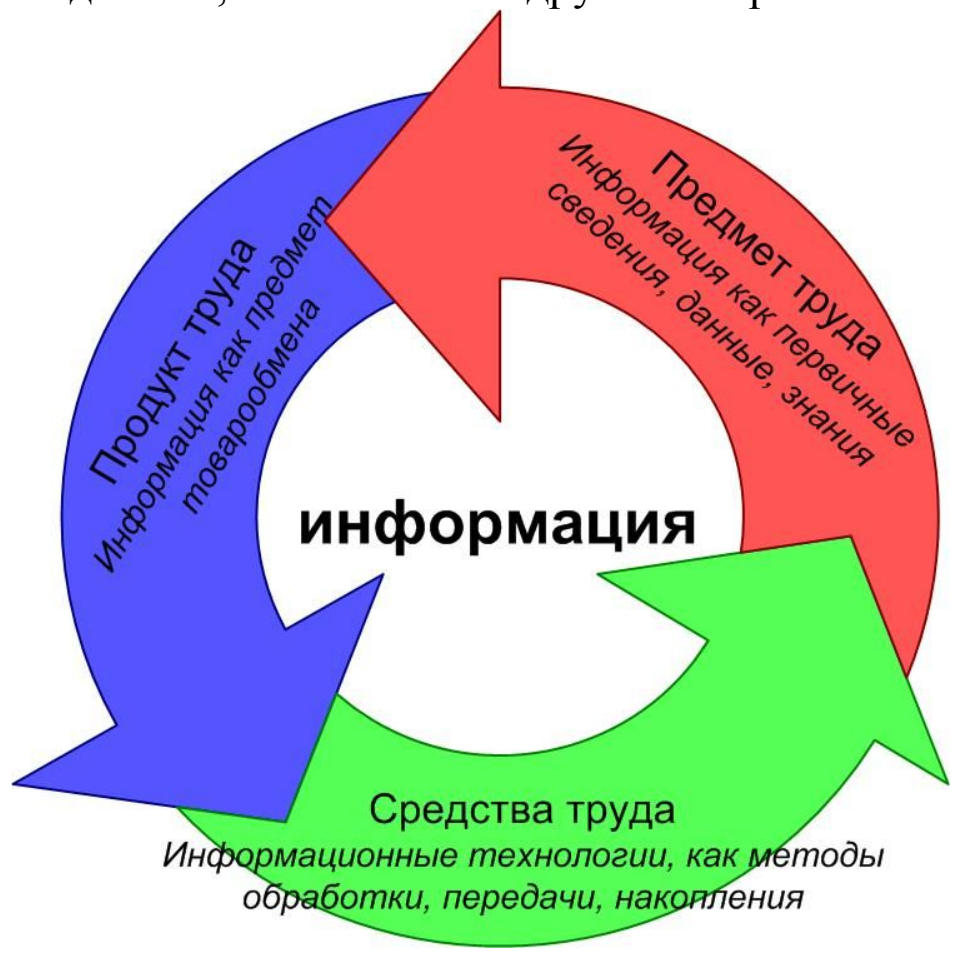

Рис. 1.1. Экономическое содержание информации как продукта, предмета и средства труда

Американские институционалисты M. J. Earl, D. F. Fenny указывают на феноменальность цикличности информации в производственных процессах. «... Уникальность информации как объекта производственных отношений состоит в цикличности ее преобразования, внутренней логической взаимосвязи ее различных содержания и объективного выражения. Преобразуя первичную информацию (предмет труда - aвm.), мы воплощаем ее в продукт, который становится инструментом (средство труда - aвт.), дающим новую первичную информацию» ${ }^{1}$.

${ }^{1}$ Earl M. J., Fenny D. F. Information Systems in Global Business: Evidence from European Multinationals. In: Earl M. J. (ed.). Information Management. Oxford: Oxford University Press, 1996. 
Свойство цикличности информации как объекта труда во многом объясняет лавинообразный, экспоненциальный рост информационных потоков, окружающего сегодня индивидуума и организацию. Вызывает необходимость непрерывного совершенствования средств труда (информационных технологий) для преобразования растущих объемов информационных потоков, сохранения их качественных характеристик. Именно этим и вызван рост значимости информационных технологий, их бурное развитие в постиндустриальную, информационную эпоху.

\section{2. РОЛЬ ИНФОРМАЦИИ В ДЕЯТЕЛЬНОСТИ ПРЕДПРИНИМАТЕЛЬСКИХ СТРУКТУР В РЕТРОСПЕКТИВНОМ АСПЕКТЕ}

Обозначенное в предыдущем параграфе экономическое содержание информации в современном постиндустриальном обществе не было изначально задано самим феноменом. Роль и значение информации в развитии общества и субъекта предпринимательства непрерывно эволюционировали, изменялись формы и концепции использования информации в управлении социальной, производственной и экономической деятельности. Существующие подходы к анализу эволюции концепций управления информацией не в полной мере отвечают задачам настоящего исследования, так как они построены в различных исследовательских контекстах: формирования рынка информации; роли информации в социальноэкономическом развитии общества ${ }^{2}$; роли компьютерных технологий в развитии социального взаимодействия ${ }^{3}$.

В данном исследовании представляется целесообразным отразить эволюционный процесс изменения роли информации применительно к субъекту предпринимательства. Выделенные научные этапы, исследователи, сформировавшие теоретический базис и парадигму, форма проявления в деятельности организации сведены в табл. 1.4, а структура взаимосвязи этапов дана в виде схемы на рис. 1.2.

Таблица 1.4

Научные этапы изменения роли информации в деятельности организации

${ }_{1}^{1}$ Ващуекин Н.П., Пасхин Е.Н., Урсул А. Д. Информатизация общества и устойчивое развитие. М., 2000.

2 Курицкий $A$. Б. Интернет: инфраструктура информационного общества. СПб.: Судостроение. 1999.

${ }^{3}$ Bawden D. J. Information and digital literalizes: a review of concepts // oc. 2001. N 2. 


\begin{tabular}{|c|c|c|c|}
\hline Научный этап $^{1}$ & Исследовате & Теоретический базис и & Проявление в организации \\
\hline $\begin{array}{l}\text { Количественн } \\
\text { ый }\end{array}$ & $\begin{array}{l}\text { К. Шеннон, } \\
1963\end{array}$ & \begin{tabular}{lr} 
Tеория & \multicolumn{2}{r}{ информации } \\
(математическая & теория \\
связи). & Понимание \\
информации & как объекта \\
передачи, & обладающего \\
количественными & \\
характеристиками
\end{tabular} & \begin{tabular}{|lr} 
Формализация & единиц \\
информации, информационных \\
потоков. \\
представления & Формирование \\
«информационной & \\
деятельности», & обаботе \\
информацией в рамках функций \\
сотрудников организации
\end{tabular} \\
\hline Качественный & D. Bell, 1973 & $\begin{array}{l}\text { Tеория коммуникаций. } \\
\text { Информация как ресурс, } \\
\text { обладающий качественными } \\
\text { и количественными } \\
\text { характеристиками }\end{array}$ & $\begin{array}{lr}\text { Информация } & \text { воспринимается } \\
\text { как ресурс в производственных } \\
\text { процессах. } \\
\text { понятия } \text { Формирование } \\
\begin{array}{ll}\text { хозяйственных } \\
\text { организации }\end{array} \\
\end{array}$ \\
\hline Разде & $\begin{array}{l}\text { М. Полани, } \\
1976\end{array}$ & $\begin{array}{l}\text { Разделение информации на } \\
\text { формализованную } \\
\text { (документы) } \\
\text { неформализованную } \\
\text { (скрытую) }\end{array}$ & $\begin{array}{l}\text { Доминирование } \\
\text { формализованной информации, } \\
\text { документооборот }\end{array}$ \\
\hline $\begin{array}{l}\text { Кибе } \\
\text { тиче }\end{array}$ & $\begin{array}{l}\text { Н. } \\
1955\end{array}$ & \begin{tabular}{|lr} 
Tеория & экономической \\
кибернетики. Информация \\
как элемент системы \\
управления
\end{tabular} & \begin{tabular}{|ll}
\multicolumn{2}{|l}{ Формализация } \\
информационных \\
принятии оснований \\
решений. & управленческих \\
технологических & Автоматизация
\end{tabular} \\
\hline $\begin{array}{l}\text { Информа- } \\
\text { ционной } \\
\text { Экономики }\end{array}$ & $\begin{array}{ll}\text { M. } & \text { Porat, } \\
1976 & \end{array}$ & $\begin{array}{l}\text { Tеория информационной } \\
\text { экономики. Информация } \\
\text { это распределенный ресурс, } \\
\text { определяющий дальнейшее } \\
\text { развитие производительных } \\
\text { сил общества }\end{array}$ & $\begin{array}{l}\text { Появление и о оформление } \\
\text { внутренних информационных } \\
\text { систем организации, рынка } \\
\text { информации }\end{array}$ \\
\hline Сетевой & $\begin{array}{l}\text { C. Anto- } \\
\text { nelli, } 1982\end{array}$ & \begin{tabular}{|lr} 
Теория сетей & и \\
Инфрафов. \\
управленческий & как \\
технологический & ресурс \\
может быть распределена по \\
узлам (источникам) сети
\end{tabular} & \begin{tabular}{|lr} 
Появление & \multicolumn{2}{c}{ концепции } \\
распределенной информации по \\
источникам & обработки \\
накопления &
\end{tabular} \\
\hline $\begin{array}{l}\text { Управления } \\
\text { знаниями }\end{array}$ & Карл Виинг & $\begin{array}{l}\text { Вид } \\
\text { деятельности и специальная } \\
\text { функция } \\
\text { знаниями, непосредственно } \\
\text { связанное с использованием } \\
\text { современных } \\
\text { информационных }\end{array}$ & $\begin{array}{l}\text { Ресурс и объект управления во } \\
\text { всех подразделениях и в } \\
\text { рамках всех функций }\end{array}$ \\
\hline
\end{tabular}

${ }^{1}$ Названия носят идентификационный характер в контексте настоящего исследования. 


\begin{tabular}{|c|c|c|c|c|}
\hline $\begin{array}{l}\text { Инфраструкту } \\
\text { рный }\end{array}$ & $\begin{array}{l}\text { O. Hanseth, } \\
\text { J. } \quad \text { Pironti, } \\
2004\end{array}$ & $\begin{array}{l}\text { Информация } \\
\text { обеспечивающая } \\
\text { окружения } \\
\text { сокращающая } \\
\text { увеличивающая }\end{array}$ & $\begin{array}{r}\text { как } \\
\text { система } \\
\text { менеджера, } \\
\text { время и } \\
\text { качество }\end{array}$ & $\begin{array}{l}\text { Реализация } \\
\text { эффективности } \\
\text { (пертинентности) } \\
\text { информационных потоков }\end{array}$ \\
\hline
\end{tabular}

Научной предпосылкой формирования исторически первого этапа эволюции роли информации в предпринимательских структурах (в настоящем исследовании он получил название «количественный», см. табл. 1.4) можно выделить разработку в 1963 г. Клодом Шенноном теории информации, также именуемой как математическая теория связи - раздел прикладной математики, определяющий понятие информации, ее свойства и устанавливающий предельные соотношения для систем передачи данных ${ }^{1}$. Шеннон стремился развить представление об информации как объективном явлении природы, подпадающем под количественное описание. В основе парадигмы лежал сформированный диалектический признак информации проявление в процессах передачи. С научной точки зрения впервые возникло понимание информации как объекта передачи, обладающего количественными характеристиками с математической точки зрения. Процесс передачи информации подразумевает пять аспектов (рис. 1.3), выраженных в последовательной взаимосвязи. Теория информации описывает в математическом виде процесс формирования и преобразования сообщения как единичного сообщения.

Данная научная парадигма нашла свое отражение в деятельности субъектов предпринимательства, привела к формализации информации, потоков во внутриорганизационных и внешних взаимоотношениях. Формируется понятие единицы информации, ее объективности как объекта, предмета труда в производственных отношениях, что приводит к осознанию «информационной деятельности» ${ }^{2}$. Работа с информацией (получение, обработка, передача) выделяется в самостоятельный процесс сотрудников компании (пока в рамках исполняемых ими производственных и управленческих функций).

Дальнейшее научное развитие количественной концепции Шеннона естественным образом сместилось к вопросам качественной стороны информации, то есть содержательной стороны сообщения (см. рис. 1.3), его изменения в процессах передачи и интерпретации получателем. Исследование качественного аспекта информации (соответственно, данный этап получил название «качественный», см. табл. 1.4) происходило в рамках теории коммуникаций. Наиболее значимые результаты исследования качественного аспекта информационных потоков субъектов предпринимательской деятельности представлены в работах американского исследователя D. Bell, предложившего выделить информацию в самостоятельный объект труда в процессах компании, а так же выделить ее экономическое содержание как предмета и средства труда. Очевидно, что выделение информации в самостоятельный предмет труда, обладающий продуктовой формой, приводит к формализации ее как ресурса в производственных процессах. Масштабность информационных процессов в социально-экономических взаимоотношениях, ее продуктовая формализованность дает основание D. Bell ${ }^{3}$

${ }^{1}$ Шеннон К. Работы по теории информации и кибернетике. М.: Изд-во иностр. лит., 1963.

${ }^{2}$ Мазур М. Качественная теория информации. М.: Мир, 1974.

${ }^{3}$ Bell D. The coming of Post-industrial Society. A Venture in Social Forcas-ting N.Y., 
рассуждать как о выраженности постиндустриальной эпохи, так и о выделении пятого сектора экономики - информационного.

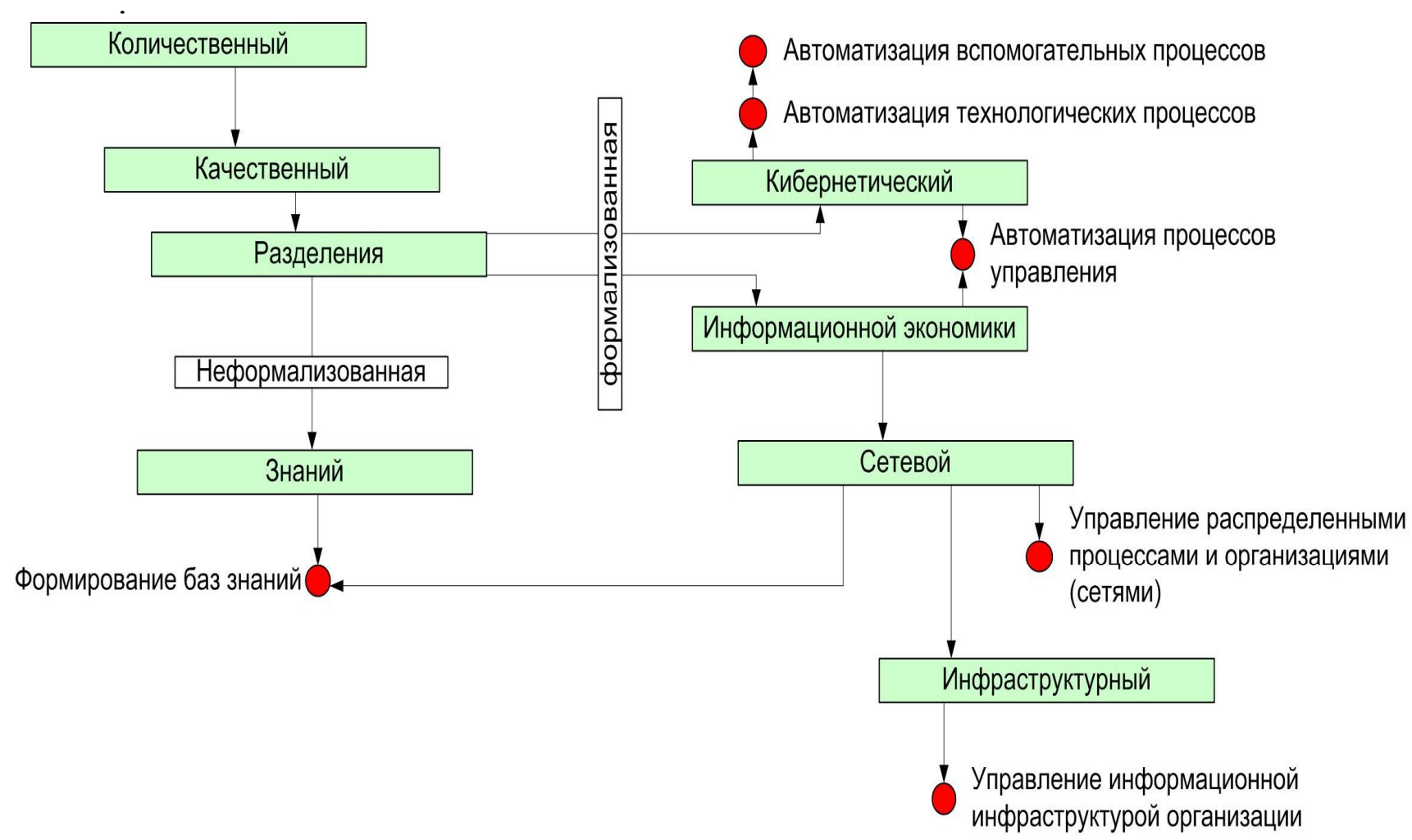

Рис. 1.1 - Взаимосвязь научных этапов исследования феномена информации и основные прикладные аспекты использования (круг) информационных технологий в предпринимательской деятельности организации.

Важнейшей научной парадигмой, разделившей дальнейшее развитие информационных концепций субъектов предпринимательской деятельности (отсюда название - этап «разделения», см. рис. 1.2) на два вектора, является теория М. Полани о кодифицируемой информации. В основе научных положений Полани (1976) лежит «...разделение информации на неформализованную и формализованную» ${ }^{1}$. Формализованная (или кодифицируемая) информация зафиксированные и документированные сведения, которые могут быть классифицированы по области применения и находиться в открытом доступе. Неформализованная информация (или знание, персональная, скрытая имплицитная) - сформированная в результате деятельности специалиста и представляющая собой невыраженный набор сведений, опыта, компетенции, интуиции. Полани сформулировал, что все научные результаты Шеннона и Bell имеют отношение исключительно к процессам работы с формализованной, кодифицируемой информацией, «...которая отделена от субъекта в независимый семантический код». В этом периоде научный мир был окрылен возможностями,

Basic Books, Inc., 1973.

${ }^{1}$ Полани М. Личностное знание. На пути к посткритической философии /под ред. В. А. Лекторского, В. А. Аршинова; пер. с англ. М. Б. Гнедовского, Н. М. Смирновой, Б. А. Старостина. М., 1995. 
которые открывались информационными технологиями с точки зрения управления формализованной информацией и исследование вопросов неформализованной остались в стороне вплоть до начала 21-го века (этап знаний рассмотрен в дальнейшем контексте работы). Полани сформировал принципы и подходы к формализации информационных потоков, что было с интересом воспринято со стороны организаций, которые на этом этапе приняли информационную деятельность как самостоятельную и искали механизмы ее регламентирования. Как раз на этом этапе развития в компаниях вводится понятие документооборота, выражающего движение единиц формализованной информации. Информация представляется исключительно как формализованный семантический ряд, документ: «...под информацией мы понимаем формализованные в документ сведения» ${ }^{1}$. Такой подход определил содержание и направление дальнейших исследований роли и места информации субъектов предпринимательской деятельности.

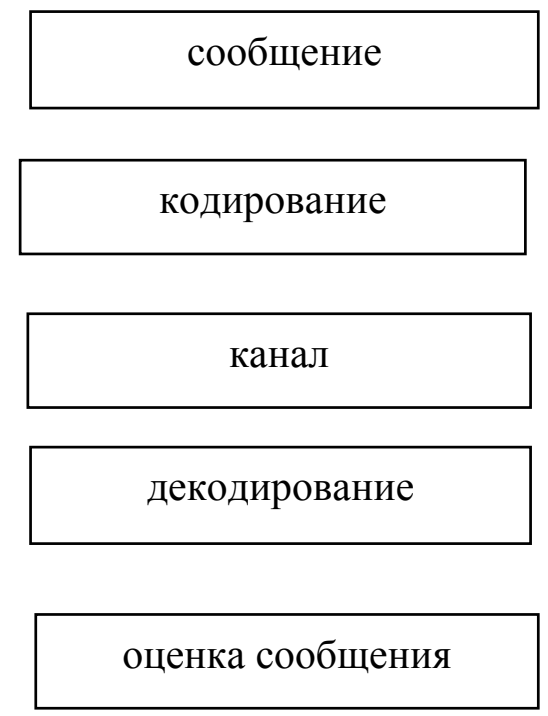

\section{Рис. 1.3 - Аспекты изучения информационных процессов в теории информации (Шеннон К.).}

Этап, четко наследующий понимание информации как формализованного ресурса, очевидно, можно обозначить как «кибернетический». На этом этапе формализованная информация рассматривается как основание для принятия субъектами предпринимательской деятельности управленских решений. Научной основой данного этапа является теория кибернетики Н. Винера. Кибернетика понимается как «наука об общих закономерностях процессов управления и передачи информации в машинах, живых организмах и обществе» ${ }^{2}$. Научные задачи управления в отношении компании нашли свое воплощение в «теории управления организационными системами (теории менеджмента) - раздел общей теории управления, изучающий механизмы функционирования организационных систем» ${ }^{3}$.

${ }^{1}$ Gunton T. Infrastructure: building a framework for corporate information handling. New York: Prentice Hall, 1989.

2 Эиби У. Р. Введение в кибернетику. М., 1959.

${ }^{3}$ Райзберг Б. А., Лозовский Л. ІІІ., Стародубиева Е. Б. Современный экономический 
Базовая модель управления Винера ${ }^{1}$ (рис. 1.4), принимаемая и теорией менеджмента, определяет информацию как элемент управляющего контура «системы управления».

Цели системы имеют количественную форму и представляют собой параметры, формализованную информацию. Динамика системы, ее последовательные изменения отражаются в виде информации (обратная связь), которая анализируется субъектом управления. Субъект управления создает решение (формализованное информационное сообщение), которое реализуется в виде воздействия на объект управления. Действительно, можно видеть, что «управление понимается как информационный процесс»².

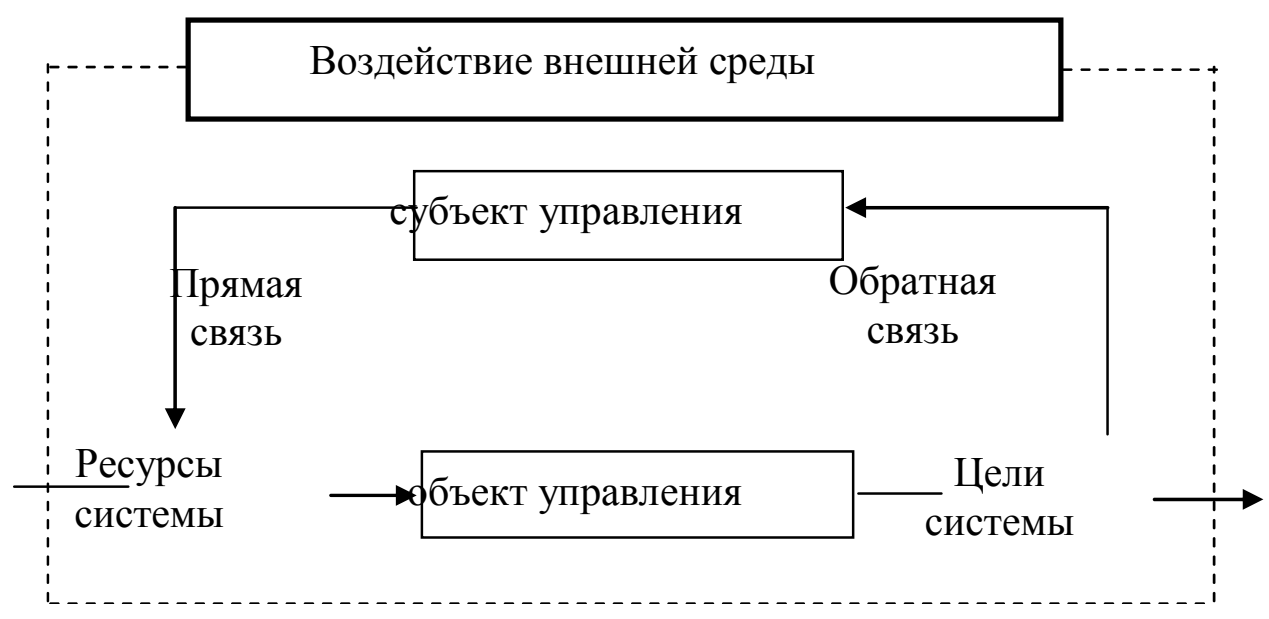

Рис. 1.4. Модель управления Н. Винера

Внедрение принципов кибернетики, формирование теории управления организацией революционным образом повлияло на характер управленческих процессов в субъектах предпринимательской деятельности, коренным образом изменило взгляды на роль информации в управлении. «Если ранее процесс управления мы принимали как «черный ящик», находящийся в голове менеджера, то сегодняшней парадигмой управления ... следует понимать и принимать формализацию информационных оснований в принятии управленческих решений» ${ }^{3}$. Циркуляция в процессах управления количественной формализованной информации привела не только к парадигме о «прозрачности управленческих решений», но и к мыслям о возможной автоматизации актов управления. Информационные технологии и развитие вычислительной техники в этом периоде (1975-1990) сформировали методическую и технологическую возможности автоматизации производственных и вспомогательных хозяйственных процессов. Появляются первые автоматизированные производства (станки с ЧПУ,

словарь. 5-е изд., перераб. и доп. М.: ИНФРА-М, 2007.

1 Винер Н. Кибернетика, или управление и связь в животном и машине. М.: Советское радио, 1958.

2 Экономическая информатика: Введение в экономический анализ информационных систем: учебник. М.: ИНФРА-М, 2005.

${ }_{3}^{3}$ Ashenfelter O., Layard R. Handbook of labor economics. Amsterdam: North-Holland Publishing Company. 1, 2. 1986. 
автоматические производственные линии), первичный контур управления которых построен на принципах кибернетики. Автоматизируется первичный уровень управления производством и вспомогательными процессами. Итак, на кибернетическом этапе развития информация стала восприниматься как количественный формализованный управленческий ресурс производственных и общехозяйственных решений в организации.

В 1976 г. M. Porat ввел и определил содержание научного термина «информационная экономика - это такой тип общественного хозяйства, где впервые в истории главным производительным ресурсом становится нечто нематериальное информация, производством, обработкой и распространением которой занимается большая часть активной рабочей силы» ${ }^{1}$. Данный этап в работе обозначен как этап «информационной экономики» (см. табл. 1.4, рис. 1.2). Информационная экономика исторически формировалась параллельно развитию основ кибернетики и наследовала теоретические представления «качественного» этапа понимания роли информации в организации. Собственно, M. Porat описал с научной точки зрения складывающуюся ситуацию: информация становится доминирующим предметом производственных и товарообменных отношений в экономике общества, во всех производственных сферах. Информация рассматривается как экономический ресурс, обретает не только внутреннюю стоимость в процессе производственных отношений (затратную), но и формируется как продукт в системах рыночного товарообмена. На фоне глобализации мировой экономики информация выступает не только как ресурс отдельных видов экономической деятельности и национальный ресурс, но и как предмет международных экономических отношений. Достаточно показательна в этом плане статистика Мирового банка (табл. 1.5) по структуре экспорта и импорта информационных услуг, демонстрирующая стабильный рост объема данных услуг в общей структуре мирового товарооборота.

Таким образом, в условиях информационной экономики доминирующим объектом труда, производственных отношений становится информация, имеющая количественное и стоимостное выражения. Переход к пониманию такой парадигмы информации в традиционных производственных и хозяйственных процессах компаний и рассматривается как этап «информационной экономики».

На этом этапе развития субъекта предпринимательской деятельности информация попадает в экономическое поле (стали его частью) товарных отношений по приобретению, продаже, взаимообмену информации, что потребовало пересмотра организационной структуры и структуры управления. Перед компанией стала проблема интеграции еe в отраслевое, национальное и мировое информационное пространство. Если ранее информационные единицы были рассредоточены по сферам деятельности (производство, финансы, управление, логистика) и выполняли локальные функции, то на новом этапе появляется понимание «информационной системы» организации. Информационная система организации ${ }^{2}$ - это совокупность управленческих, производственных и вспомогательных информационных процессов, распределенных, но взаимосвязанных в рамках целей функционирования социально-экономического объединения.

Появление концепции внутренней информационной системы стало очевидным ответом на сложившиеся на этапе «информационной экономики»

1 Porat M. The Information Economy: Definition and Measurement. US Dept. of Commerce. Wash., 1976.

2 Эшби У. Р. Введение в кибернетику. М., 1959 
условия хозяйственной и управленской деятельности предпринимательской структуры. Последующее (1990-е годы) распространение вычислительной и компьютерной техники привело к возможности автоматизации управленческих процессов, основанной на консолидации информационных потоков в рамках внутренних информационных систем предпринимательской структуры (рис. 1.5). Концепцию внутренней информационной системы организации, порожденную информационной экономикой, можно охарактеризовать как «феодальную», закрытую от внешней среды. Что выражается в максимальном сосредоточении в информационном поле организации всех необходимых (и кажущихся необходимыми) сведений для функционирования организации, баз данных, накоплении информации по всем аспектам внутренней, отраслевой, национальной и международной деятельности.

Таблица 1.5

Экспорт и импорт информационных услуг в структуре коммерческих услуг по данным Мирового Банка ${ }^{1}$

\begin{tabular}{|c|c|c|c|c|}
\hline \multirow[t]{2}{*}{ Страна } & \multicolumn{2}{|c|}{$\begin{array}{l}\text { Объем коммерческих услуг, } \\
\text { млн USD }\end{array}$} & \multicolumn{2}{|c|}{ Процент информационных услуг } \\
\hline & 1990 г. & 2004 г.* & 1990 г. & $2004 \mathrm{r}$. \\
\hline \multicolumn{5}{|l|}{ Экспорт } \\
\hline Китай & 5,748 & 62,056 & 18,7 & 38,3 \\
\hline Германия & 50,561 & 133,856 & 41,5 & 47,8 \\
\hline Россия & & 20,164 & & 32,9 \\
\hline Англия & 53,830 & 179,649 & 29,4 & 45,1 \\
\hline США & 132,880 & 321,837 & 30,5 & 44,8 \\
\hline Мировые & 815,710 & $2,190,577$ & & \\
\hline Средний & & & 22,3 & 27,3 \\
\hline \multicolumn{5}{|c|}{ Импорт } \\
\hline Китай & 4,113 & 71,602 & 7,4 & 30,2 \\
\hline \multicolumn{5}{|c|}{$\begin{array}{l}\text { *В более поздних периодах Мировой Банк и системы национальной статистики не } \\
\text { проводили аналогичных исследований. На } 2009 \text { год, мы, к сожалению, располагаем только } \\
\text { сведениями по вопросу сформированными Мировым банком в } 2006 \text { году. Впрочем, } \\
\text { экспертная оценка показывает, что значительных изменений в тенденциях роста в период } \\
2004-2008 \text { года не происходила; Hanseth, O. From systems and tools to networks and } \\
\text { infrastructures - From design to cultivation. Towards a theory of ICT solutions and its design } \\
\text { methodology implications, Oxford Press - 2004. }\end{array}$} \\
\hline
\end{tabular}

1 Акулов В. Б., Рудаков М. Н. Теория организации: учеб. пособие. Петрозаводск: ПетрГУ, 2002. 


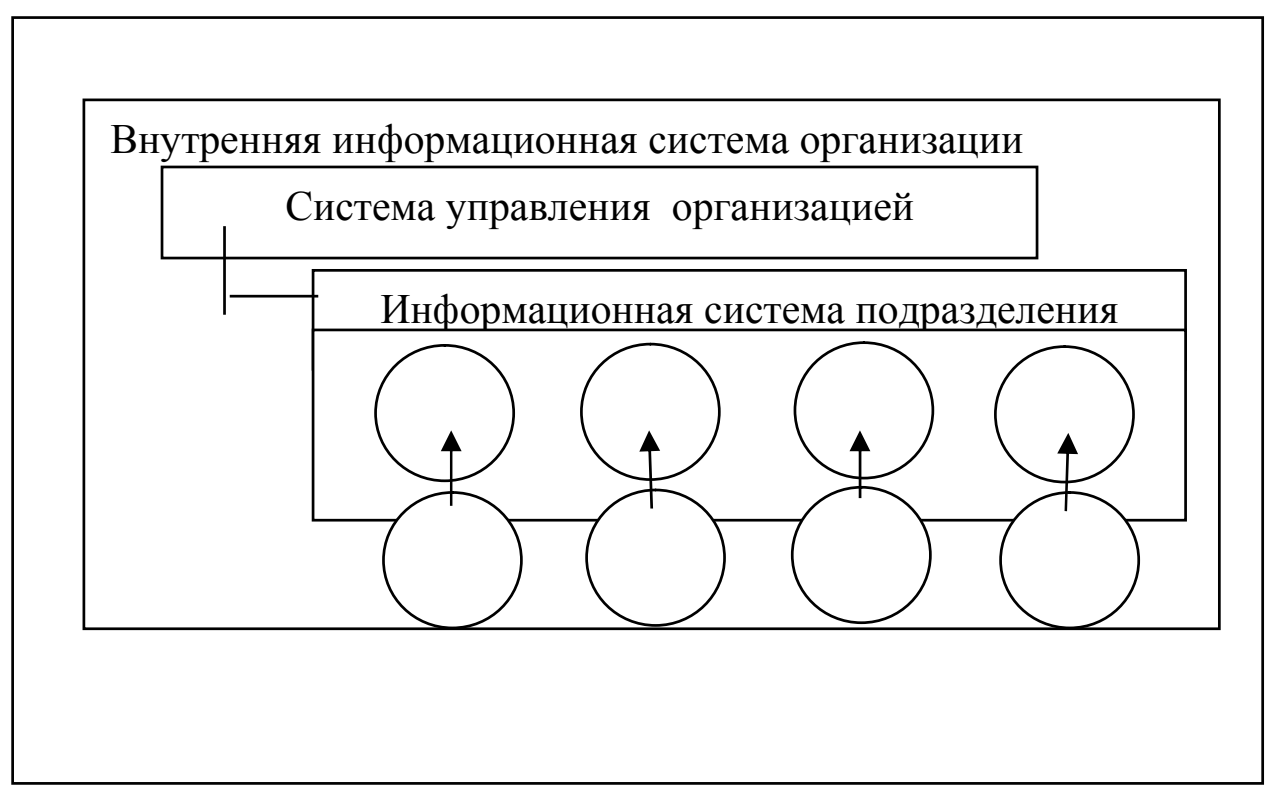

Рис. 1.5. Концепция внутренней информационной системы организации: / — информационные потоки

Часто это приводило (и приводит) к ситуациям, когда организации в своих информационных функциях начинают подменять специализированных информационных агентов, исследовательские группы и компании, чьей сферой деятельности является актуализация баз данных. Тем не менее, реализация концепции внутренней информационной системы организации была значительным, революционным шагом в развитии экономической сущности информации в организации.

Предпосылками «сетевой» концепции этапа (см. табл. 1.4, рис. 1.2) можно определить три фактора. Первый фактор - концепция «внутренней информационной системы организации» (1982 г.), доминировавшая на этапе «информационной экономики», не оправдала надежд. В процессе использования ее в качестве модели информационного пространства организации были выявлены серьезные недостатки ${ }^{1:}$ низкое качество информации (уровень актуальности, содержание шума, стоимость производства информации); высокие трансакционные расходы процессов приобретения, обработки и внутреннего распределения информационных потоков. «...Парадокс, но внедрение концепции внутренней информационной системы ведет к увеличению трансакционных расходов организации. Хотя, как мы понимаем, изначальной установкой системы определялось положительное влияние на уровень издержек на поиск информации...»². Bmopылм фактором является разработка научных принципов сетевой модели управления распределенными ресурсами и процессами. Концепция

1 Walsham, G. Interpreting Information Systems in Organizations. Chichester: Wiley, 1993.

2 Braa K., Rolland K. H. Horizontal Information Systems: Emergent Trends and Perspectives. In: Baskerville, R., Stage, J. and De Gross, J. I. (eds.). 2000. Organizational and Social Perspectives on Information Technology. Boston: Kluwer Academic Publishers, 2000. 
в качестве своего научного базиса определила теорию сетей и графов ${ }^{1}$. Сетевая концепция первично нашла свое применение в управлении географически распределенными стратегическими хозяйственными единицами (CXE) организаций, a вторично была принята теорией менеджмента как «...актуальный текущему социально-экономическому развитию подход к управлению распределенными ресурсами организаций» ${ }^{2}$. Третьим фактором можно определить революционный скачок в развитии инфокоммуникационных технологий -появление нового доступного поколения сетей связи (интернет, сотовая связь, глобальные информационные сети, распределенные сетевые базы данных и другие, подробно исследованные в работе). Появление технологической возможности реализации информационных сетей сформировало механизмы доступа к любой удаленной информации, сняло потребность в построении закрытых внутренних информационных систем организации.

Информационное пространство, в котором находятся организации, претерпевает очередное эволюционное изменение. Информационные сети реализуют прорыв в области формирования и доступа к информации: генерируются колоссальные потоки информации как организациями, так и частными лицами; коммерциализация сетей (реклама) обеспечивает всеобщий бесплатный доступ к сетям; экспоненциально растет аудитория сетей; процессы продаж промышленной и потребительской продукции перемещаются в информационные сети; сети смывают географические границы в товарообмене, производственных процессах, финансовой деятельности. Впрочем, все эти факторы мы можем не только со всей очевидностью наблюдать, но и испытывать на себе, например, при контакте с сетью интернет. «...Современные социально-экономические и производственные взаимоотношения по праву называют сетевыми»³.

В сущности «сетевая» парадигма управления информационными процессами субъекта предпринимательства основана на положении «информация как управленческий и технологический ресурс может быть распределена по узлам (источникам) сети» ${ }^{4}$. Основными чертами сетевой организации ${ }^{5}$ можно считать отсутствие жесткой вертикали информационных потоков; свободный горизонтальный обмен информацией; информационный аутсорсинг - информация для реализации технологических и управленческих функций может быть сосредоточена во внешней среде. Действительно, такая модель организации информационного пространства субъекта предпринимательства во многом более актуальна современным хозяйственным процессам, их темпам и логике взаимодействия субъектов управления. Сетевая концепция информационного пространства компании позволила эффективно реализовать ряд новых

${ }^{1}$ Antonelli $C$ The Economic Theory of Information Networks. In: The Economics of Information Networks. Antonelli, C. (ed.), Amsterdam: Elsevier Science Publishers, 2002.

${ }^{2}$ Мильнер Б.3. Теория организации: учебник. 7-е изд. М.: Инфра-М, 2008.

3 Бувалин M. Ю. Специфика развития регионального рынка рекламы как составляющей информационной рыночной инфраструктуры (на примере Республики Татарстан): автореф. дис. ... канд. экон. наук: 08.00.05. Казань, 2005.

4 Гриненко A. С. Экспертная классификация информации // Сб. науч. тр. Вып. 6. Шахтинский технологический институт. Шахты, 1994.

5 Инфокоммуникационные технологии в глобальной информационной инфраструктуре: монография / П. А. Барабаш и др.; под общ. ред. Б. Я. Советова. СПб.: Наука, 2008. 
методических решений теории менеджмента: проектное управление, управление сетевыми инновациями и трансфер технологий, управление распределенными логистическими потоками и т. п. Примером реализации сетевой концепции является сетевая информационная система регионального инвестиционно-строительного комплекса ${ }^{1}$.

Исторически параллельно сетевой концепции (с 1986 г. по настоящее время) проявилось другое видение роли информации в субъекте хозяйствования, основанное на переосмыслении, ревизии роли неформализованной информации (см. рис. 1.2). Основой новой парадигмы является формирование, обновление и применение знаний для максимизации эффективности компаний и этап управления знаниями (см. табл. 1.3). Термин «управление знаниями» был введен в научный оборот в 1986 г. Карлом Вигом в его выступлении на конференции Международной организации труда, проводившейся под эгидой $\mathrm{OOH}^{2}$. Знание понимается как совокупность навыков, умений, опыта, компетенций персоналаз ${ }^{3}$. Носителем знания является субъект, индивидуум. Именно знание, будучи транслировано (передано) в сообщение, представляет собой самый ценный информационный ресурс предприятия. Ценность его определяется тем, что знание всегда тесно связано с решаемой задачей, лишено шумов (помех), выражено как решение (или варианты решения), то есть может рассматриваться как наиболее эффективная качественная информация. Позиция о ценности знания разделяется всеми учеными в области современного менеджмента, даже теми, кто является апологетом других информационных концепций. Обратной стороной знания является его неформализованность, недокументированность в виде накопленных сведений. Именно это затрудняет включение «знаний» в современные информационные системы организаций. Концепция менеджмента знаний оказала существенное влияние на представления о роли информации в компании. Она сформировала понимание, что процесс управления субъектом предпринимательства не может быть полностью автоматизирован. Эта концепция внесла новое понимание информационной роли менеджера как носителя знаний, поставила под сомнение «механистическое» отношение к информационному полю субъекта предпринимательства, попытки «...синтезировать интеллектуальные системы управления, которые могут полностью заменить человека в его менеджерской функции» ${ }^{4}$. Поэтому одной из задач нашего исследования является методика формирования и развития системы создания и управления организационным знанием субъекта предпринимательской деятельности.

Реализуемая сетевая концепция развития инфокоммуникаций привела не только к росту прозрачности и доступности информации в социальноэкономической сфере, но и вызвала экспоненциальный рост объемов информационных потоков. Ситуационная негативная оценка роста потоков,

${ }^{1}$ Асаул A. H, Иванов C. Н. Снижение трансакционных затрат в строительстве за счет оптимизации информационного пространства. АНО ИПЭВ, 2008.

${ }^{2}$ Мильнер Б. 3. Теория организаций: курс лекций: учеб. пособие для вузов по спец. «менеджмент». М.: ИНФРА-М, 1999.

${ }^{3}$ Нонака И., Такеучи Х. Компания - создатель знания. Зарождение и развитие инноваций в японских фирмах / пер. с англ. М.: ЗАО «Олимп-Бизнес», 2003.

${ }^{4}$ Meтоды и средства информационной технологии на основе систем баз данных и знаний // Сб. науч. тр. АН УССР, Науч. совет по пробл. Кибернетика. Ин-т кибернетики им. В. М. Глушкова; редкол.: А. А. Стогний (отв. ред.) и др. Киев: ИК, 1988. 
окружающих индивидуума в его социальной, производственной и экономической деятельности, обусловлена высоким содержанием шума. Шум (упрощенно - помехи) формирует информационную неопределенность, приводящую к невозможности целенаправленных действий индивидуума или компании, к энтропии и хаосу системы. Высокое содержание шума обусловлено отсутствием организационной структурированности информации, множественным дублированием информационных потоков (в том числе в различных семантических формах), значительным ростом доли ложной и паразитной информации, технической сложностью выделения релевантной (упрощенно-полезной) информации. Современная информационная насыщенность и организация информационного поля скорее дезориентирует индивидуума, компанию, чем создает основание для эффективных решений. Данные предпосылки естественным образом привели к формированию нового этапа, «инфраструктурной» концепции построения информационного поля субъекта предпринимательской деятельности.

Концепция информационной инфраструктуры, предложенная O. Hanseth, J. Pironti (2004-2006 г.), основана на методах информационных технологий (рис. 1.6). Комплекс методов обеспечивают обработку неорганизованного (внутреннего и внешнего) информационного потока, превращает его в релевантную (отфильтрованную, преобразованную к целям использования) информацию, адресованную сотруднику компании для исполнения своих обязанностей в рамках хозяйственной или управленческой деятельности. Организованный в систему оптимизации информационных потоков комплекс методов обработки, накопления и передачи информации обозначается как информационная инфраструктура.

Парадигмой концепции информационной инфраструктуры является понимание роли информации как обеспечивающей системы окружения менеджера, сокращающая время и увеличивающая качество принятия решений за счет повышения эффективности (пертинентности) информационных потоков.

Концепция информационной инфраструктуры является самым актуальным современным взглядом на роль информации не только в компаниях, но и в межотраслевых комплексах ${ }^{1}$. При этом нужно понимать, что будучи эволюционно последовательной она наследует черты сетевой и внутренней информационной системы. С одной стороны, эта концепция не отрицает сетевого информационного пространства, построена с учетом сетевых принципов. С другой стороны, отрицая замкнутость и закрытость подходов концепции внутренней информационной системы, использует ее алгоритмы обработки и распределения внутренних информационных потоков. Концепция информационной инфраструктуры наследует черты предыдущих научных подходов и вместе с тем предлагает новый взгляд на роль информации в компании. Его в целом можно охарактеризовать как прагматический, рациональный по отношению к информации, используемой в хозяйственной и управленческой деятельности субъектов предпринимательства.

${ }^{1}$ Асаул А. Н, Иванов С. Н. Снижение трансакционных затрат в строительстве за счет оптимизации информационного пространства. СПб.: АНО ИПЭВ, 2008. 


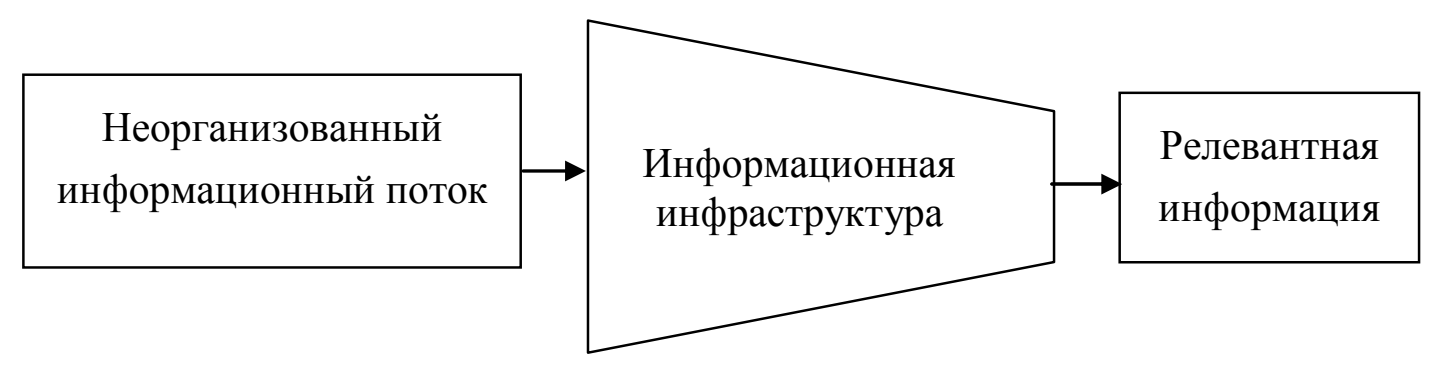

Рис. 1.6. Парадигма концепции информационной инфраструктуры субъекта предпринимательской деятельности

\section{3. СОЗДАНИЕ ОРГАНИЗАЦИОННОГО ЗНАНИЯ - ВАЖНЕЙШИЙ ИСТОЧНИК КОНКУРЕНТОСПОСОБНОСТИ ПРЕДПРИНИМАТЕЛЬСКОЙ СТРУКТУРЫ}

Великий русский философ Владимир Соловьев дает такое определение знанию: «знание - самое общее выражение для обозначения теоретической деятельности ума, имеющей притязание на объективную истину (в отличие, например, от мышления или мысли, которые могут быть заведомо фантастичны). Термины знание и познание, относясь в сущности к одному и тому же предмету, различаются некоторым оттенком: первый относится более к объективной стороне умственного процесса, второй - более к его субъективным условиям. Впрочем, это различие, весьма относительное и нетвердое, редко выдерживается; обыкновенно обоими терминами пользуются как синонимами» ${ }^{1}$.

Но для уяснения сути термина «знание» обратимся к Питеру Друкеру, который доказывает, что в новых экономических условиях знание является не еще одним ресурсом того же порядка, что и традиционные факторы производства - труд, капитал и земля, а вообще единственным имеющим значение ресурсом. Тот факт, что знание стало единственным ресурсом, делает новую формацию уникальной ${ }^{2}$ Элвин Тоффлер также разделяет мнение Друкера и называет знание мощнейшей силой и ключом к грядущему сдвигу власти, обращая особое внимание на превращение знания из дополнения к силе денег и силе мышц в их квинтэссенцию, что объясняет разгорающуюся по всему миру войну за контроль над информацией и средствами коммуникации. Тофлер верит в окончательную замену прочих ресурсов знанием².

Сходных со взглядами Друкера и Тоффлера, придерживается и Куинн, который считает, что экономическая и производительная силы современных корпораций заключены в основном в интеллектуальной сфере и в сфере производства услуг, нежели в материальных активах, т. е. в земле, заводах и оборудовании. В

\footnotetext{
${ }^{1}$ Составлено по материалам Википедии. URL: http://ru.wikipedia.org

${ }^{2}$ Балабанов И. Т. Инновационный менеджмент. СПб.: Питер, 2001.

${ }^{3}$ Бездудный Ф.Ф., Смирнова Г. А., Нечаева О. Д. Сущность понятия инновация и его классификация // Инновации. 1998. № 2-3.
} 
своих воззрениях Куинн идет дальше, утверждая, что стоимость большей части продуктов и услуг в первую очередь определяется возможностью развития основанных на знании нематериальных активов, таких как технологические ноухау, дизайн продукции, маркетинговые исследования, понимание клиента, способность персонала к производительному труду и инновации ${ }^{1}$. Как видим вышеприведенные авторы едины в том, что будущее принадлежит людям, вооруженным знаниями. В обществе, основанном на информации, работник умственного труда (knowlege worker, у Друкера - «работник, создающий знание») представляет собой единственную и величайшую ценность. Под его определение работника умственного труда подпадают люди, владеющие знанием, умеющие применить его с выгодой, точно так же как капиталист знает, как с выгодой разместить капитал. Куинн подчеркивает, что способность к управлению, называемая им интеллект, основанньй на знаниях (knowledge-based intellect), в настоящее время быстро становится главным навыком руководителя. Рич утверждает, что единственное истинное конкурентное преимущество переходит на сторону тех, кого он определяет как «аналитики символов», и тех, кто вооружены знаниями, достаточными для постановки вопроса, его решения и получения из этого выгоды ${ }^{2}$. Все это свидетельствует не только о том, что будущее принадлежит тем, кто работает не руками, а головой, но и о том, что знание - новый конкурентный pecypc.

Организационные знания, по мнению современных ученых ${ }^{3}$, представляют собой практическую информацию, которая позволяет эффективно управлять процессами выполнения задач, разрешения проблем и принятия решений. Эта информация расширяет понимание процессов и явлений и возможности их практического использования в определенной деятельности 4 .

Знания - очень сложный феномен и для его понимания необходимо обратить внимание на три аспекта. Первый аспект - знание является воспринятой и обработанной определенным образом информацией. Что же такое информация? Считается, что информация - это данные, пропущенные через определенный фильтр. Данные, в свою очередь, представляют собой серию отдельных объективных фактов о тех или иных событиях вне связи с контекстом.

Выделяют следующие элементарные операции, которые производят, по отдельности или в комплексе, для трансформации данных в информацию: контекстуализация, категоризация, калькулирование, корректировка и сжатие. Информация - это набор данных, имеющих важность для получателя в определенном контексте.

Второй аспект - это «доказанное истинное убеждение» ${ }^{5}$ относительно чеголибо в реальности бытия или действительности мышления. Таким образом, знание -

${ }^{1}$ Балашов Е.А. Менеджмент знаний: подход к внедрению // Журнал «Стандарты и качество» Госстандарта России. URL: http://quality.eup.ru/MATERIALY/mzpv.htm

2 Баранчеев B. Управление знаниями. М.: Центр маркетинговых исследований и менеджмента, 2005.

${ }^{3}$ Адаме K. К. Пик производительности / URL: http://bigc.ru/publications/other/km/; Акофф Р. Акофф о менеджменте. СПб: Питер, 2002; Арсентьев С. Базовые понятия Knowledge Management. URL: http://bigc.ru/publications/other/km/

${ }^{4}$ Управление знаниями в корпорациях / Б. 3. Мильнер и др. М.: Дело, 2006.

5 Нонака И. Компания - создатель знания // Управление знаниями. М.: Альпина Бизнес Букс, 2006. 
это определенный предмет в сознании субъекта, который воспринимается им, как истинный; это результат процесса обработки информации, на основании которого субъект создал в своем сознании определенную мыслительную конструкцию, в истинности которой он убежден (т. е. эта конструкция не противоречит всем остальным его ментальным конструкциям). Третий аспект - знания являются основой для действия.

Следовательно, если речь идет об организационных знаниях, то можно заключить, что они представляют собой определенные мыслительные конструкции, являющиеся отражением организационной реальности, в которой функционирует субъект действия (носитель знания), либо каким-то другим образом с ней связанные, на основе которых субъект понимает, какие действия ему необходимо предпринять, чтобы получить желаемый результат. На наш взгляд, такое определение максимально точно выражает сущность организационного знания.

Независимо от того, получает ли субъект организационное знание извне, либо сам создает знание на основе своей мыслительной работы, конечный результат является именно таким. Субъект сохраняет знания, используя память, либо посредством кодирования. Кодирование представляет собой процесс превращения знания в информацию, восприняв которую и осуществив минимальную обработку ее, впоследствии становится возможным вновь создать мыслительную конструкцию на планшете сознания. Таким образом, знание всегда индивидуально. Данное определение соответствует канонам системомыследеятельностной методологии (СМД).

Знание из памяти является незакодированным, поэтому его называют неформализованным; закодированное знание принято называть формализованным, которое позволяет определить соответствие между СМД и моделью трансформации знания Икудзиро Нонаки (так называемой SECI-моделью), которая отражает трансформации одной формы знания в другую ${ }^{1}$ (рис. 1.7).

Движение по модели по часовой стрелке отражает раскручивание так называемой «спирали знания». Спираль знания начинает раскручиваться с неформализованной идеи (смутного ощущения возможности) у индивида, которая родилась у него на основе наблюдения за реальностью опыта работы с формализованным знанием различных уровней: организационным, групповым или с ме-таорганизационным (интернализация). В традиционных организациях субъект может воспользоваться полученным знанием для оптимизации собственной деятельности или не воспользоваться, но чаще знание не будет передано другим субъектам.

${ }^{1}$ Srinivasan J. Knowledge Management/J. Srinivasan //MIT Open Course Ware. URL: http://ocw.mit.edu/NR/rdonlyres/Sloan-School-of-Management/15-394Designing-and-Leadingthe-Entrepreneurial-OrganizationSpring2003/Calendar/ summaryofclasssessionsandassignmentdu.pdf 


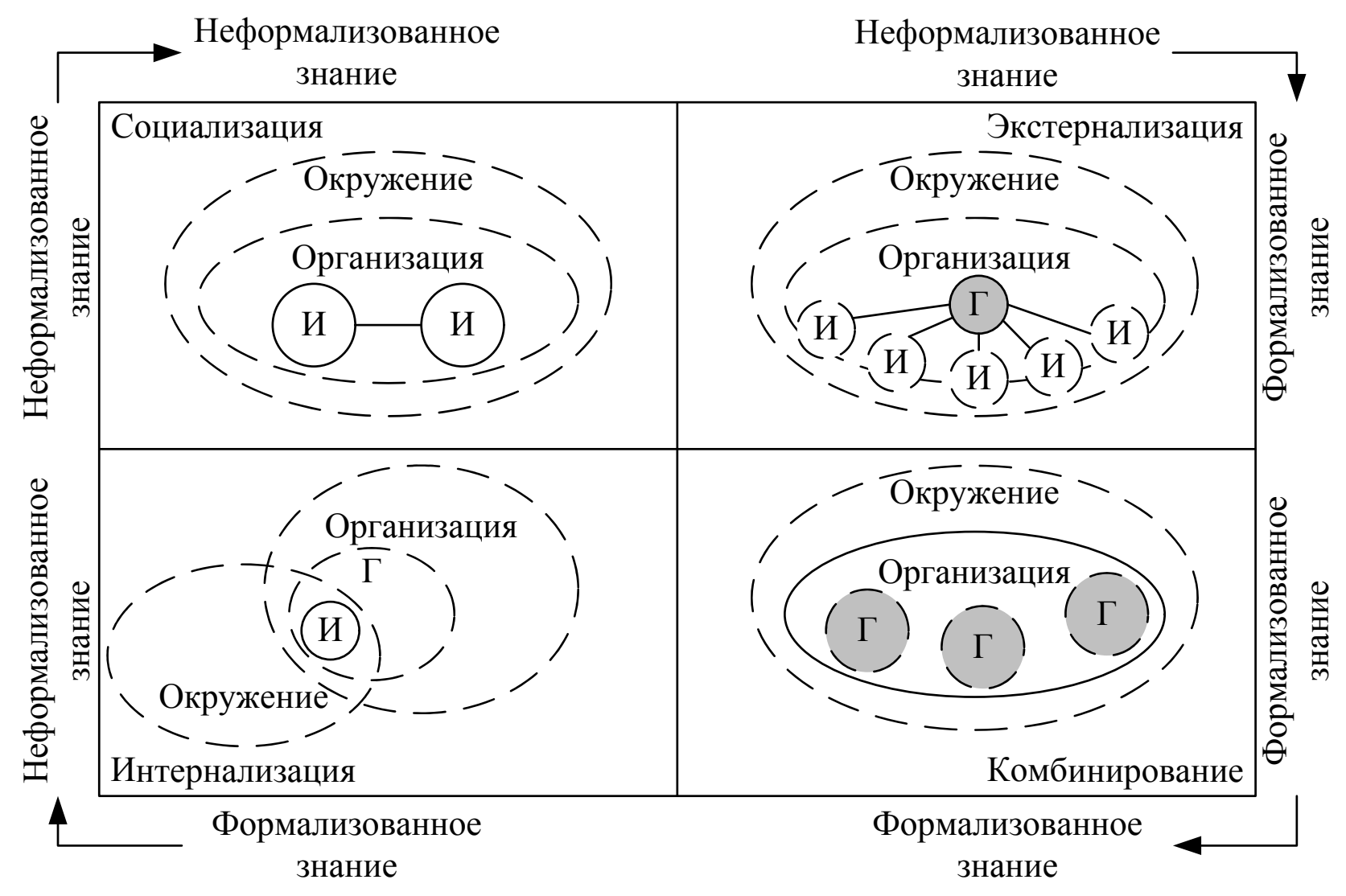

Обозначения:

И - индивид; Г - группа

Рис. 1.7. Модель развития знания по И. Нонаки

В результате оно не приведет к положительным изменениям внутри организации. В обучающихся же организациях знания постоянно циркулируют внутри организации: во-первых, индивид может поделиться полученными ощущениями с другим индивидом (социализация); во-вторых, возникшая идея может быть формализована в результате обсуждения в группе (экстернализация); втретьих, имеющееся в организации формализованное знание постоянно входит в различные комбинации с другими единицами знания (комбинирование) ${ }^{1}$.

Строго говоря, с нашей точки зрения и в соответствии с СМД, формализованное знание И. Нонаки представляет собой не что иное, как информацию. Отсюда его экстернализация - это процесс кодирования и распространения информации, комбинирование -обработка информации (перечисленными выше способами), интер-нализация - создание соответствующих мыслительных конструкций на основе информации, а социализация - рефлексия. Таким образом, описываемое чистое мышление является процедурой целенаправленного создания знания (неформализованного в терминологии И. Нонаки).

Возникшие в индустриальную эпоху организационные теории и концепции не

\footnotetext{
${ }^{1}$ Нонака И. Указ. соч.
} 
являются адекватными эпохе перемен. Это приводит к необходимости поиска новых способов постижения организационной реальности создания и развития на этой основе конкурентного преимущества субъектов предпринимательской деятельности. Большинство специалистов в области менеджмента как теоретиков, так и практиков сегодня согласны с тем, что устойчивой основой долгосрочного конкурентного преимущества современных предпринимательских структур, вне зависимости от их сферы деятельности, является создание и эффективное управление организационными знаниями. Это объясняется тем, что для достижения успеха в условиях эпохи перемен требуется повсеместная реализация организационных изменений. А организационные знания являются основой этих изменений и, следовательно, определяют их эффективность и результативность. Чтобы обосновать это положение, достаточно построить простой причинный цикл любого организационного изменения (рис. 1.8).

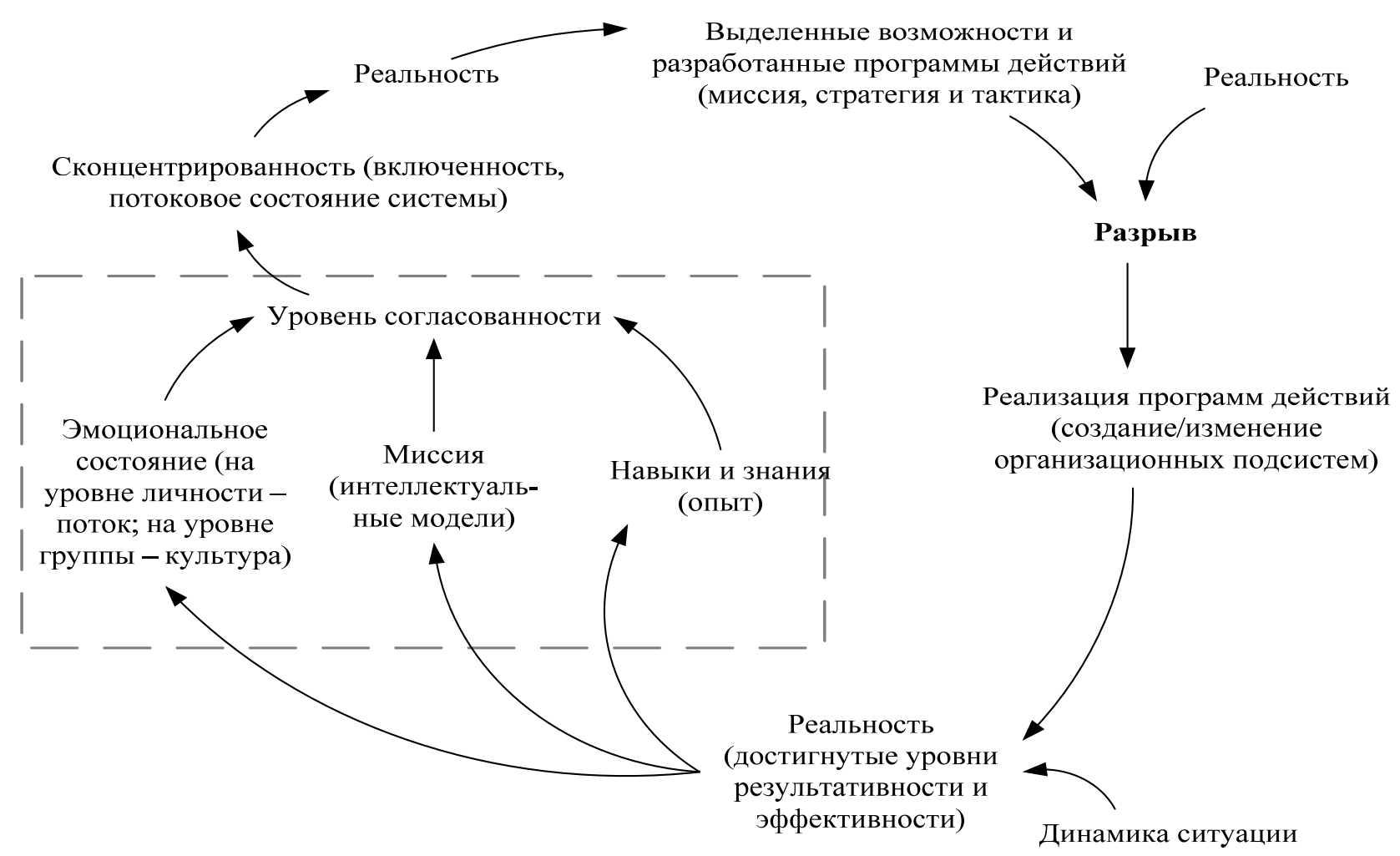

Рис. 1.8. Роль системы создания и управления знаниями в организационных изменениях

В результате становятся очевидными актуальность создания и эффективность управления организационными знаниями в процессе функционирования предпринимательских формирований: этот процесс способствует достижению субъектом мыследеятельности желаемого результата. Актуальность позволяет построить следующий отрезок причинно-следственного цикла (рис. 1.9). 


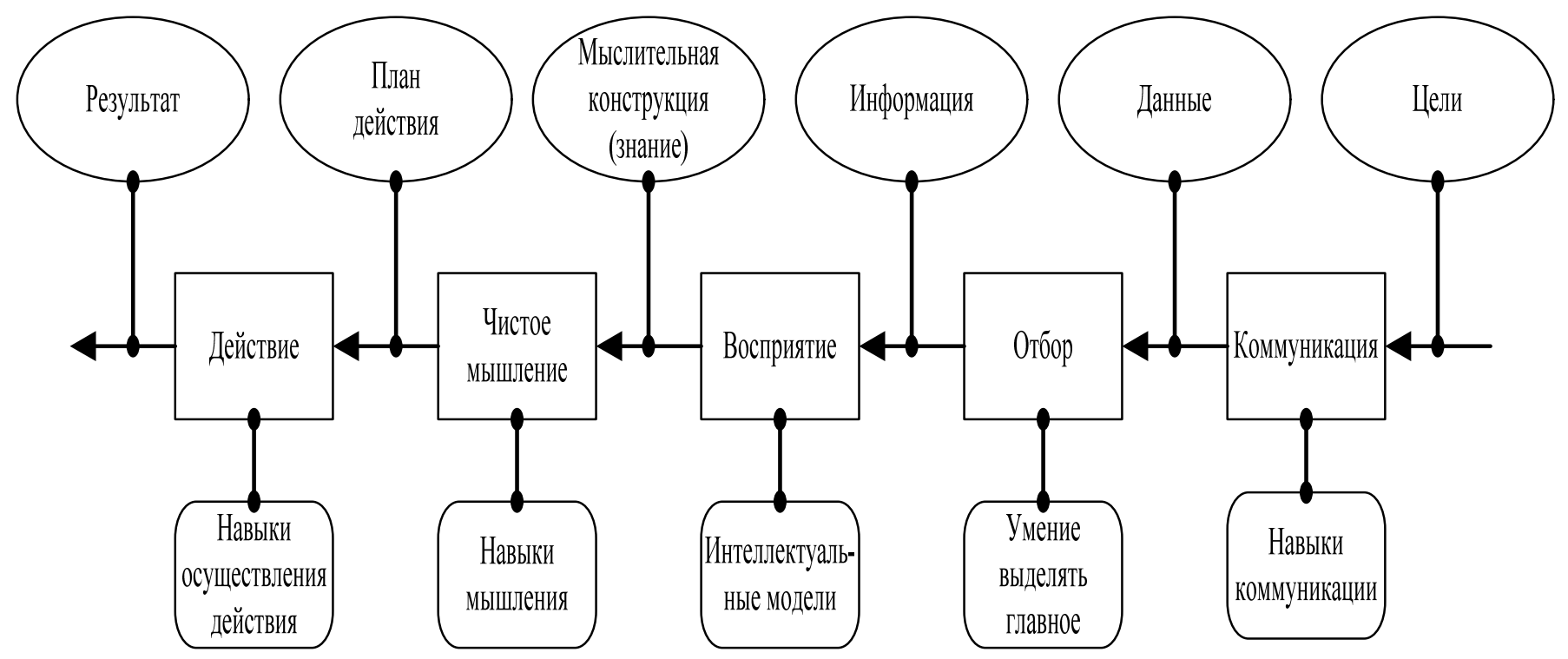

Рис. 1.9. Представление процесса мышления с позиций СМД

Следовательно, для достижения желаемого результата должно быть выполнено несколько условий:

субъект мыследеятельности должен обладать в достаточном объеме навыками чистого мышления (чтобы он был в состоянии принять необходимые решения и разработать план действий);

его интеллектуальные модели должны способствовать построению адекватной реальности мыслительной конструкции;

субъект должен хорошо разбираться в решаемых вопросах для того, чтобы суметь выделить главное;

он должен обладать соответствующими навыками коммуникации, чтобы получить иметь доступ к соответствующим данным;

цели субъекта должны соответствовать целям предпринимательских формирований.

Перечисленные условия определяют в первом приближении задачи, которые в общем случае должна эффективно решать ССУОЗ (система создания и управления организационными знаниями). Критерием эффективности функционирования ССУОЗ является уровень эффективности решения менеджерами стоящих перед ними задач. Для достижения высокой эффективности функционирования ССУОЗ необходимо, чтобы ССУОЗ была адекватна ситуационным особенностям деятельности менеджеров.

C позиции СМД любое знание принадлежит какой-либо категории ${ }^{1}$, из чего следует, что оно обладает четырьмя категориями содержания: объект, к которому оно относится; действия-операции, которые реализуются по отношению к этому объекту; язык описания, представляющий собой совокупность правил (принципов) создания предмета (моделирования объекта); понятия, которые относятся к предмету знания.

Г. Я. Гольдштейн следующим образом классифицирует организационные

1 Путеводитель по методологии Организации, Руководства и Управления: хрестоматия по работам Г. П. Щедровицкого / сост. А. П. Зинченко. М.: Дело, 2003. 
знания ${ }^{1}$ :

- Коренные знания представляют необходимый минимум, который обеспечивает «участие в игре». Обладание ими не может обеспечить долговременную конкурентную значимость фирмы, но создает определенный барьер входу в отрасль. То есть, коренные знания обычно имеют все участники отрасли и, следовательно, они обеспечивают определенное преимущество перед фирмами, желающими войти в отрасль.

- Знания, обеспечивающие успех, снабжают предпринимательскую организацию конкурентным потенциалом, который может иметь в общем тот же самый уровень или качество знаний, как и ее конкуренты, но некоторые специфические знания могут повысить конкурентоспособность системы управления предпринимательской структурой. Эти компании могут претендовать на успех в сходной конкурентной позиции, так как именно там они знают больше конкурентов.

- Инновационные знания предоставляют субъекту предпринимательства возможность изменять «правила игры». Именно они и дают возможность быть лидерами.

Создание организационного знания - это способность компаний как единого целого создавать новое знание, распространять его по организации и воплощать в продукции, услугах и системах. Необходимо подчеркнуть, что процесс создания знания представляет собой топливо для инновационного процесса, в то время как знание само по себе таким топливом не является. Другими словами, процесс создания нового организационного знания в виде новой продукции, услуг или систем - краеугольный камень инновационной деятельности предпринимательских структур.

Большинство специалистов в области управления (как теоретиков, так и практиков) сегодня согласны с тем, что устойчивой основой долгосрочного конкурентного преимущества современных компаний, вне зависимости от сферы деятельности, является создание и эффективное управление организационными знаниями. Это объясняется тем, что для достижения успеха в условиях эпохи перемен требуется повсеместная реализация организационных изменений. А организационные знания являются основой этих изменений и, следовательно, определяют их эффективность и результативность.

Создание и эффективное управление организационными знаниями означает постановку и развитие соответствующей системы в предпринимательских формированиях. Эффективность же этой системы может определяться только опосредованно - через эффективность основной деятельности предпринимательской структуры, то есть система создания и управления организационными знаниями предпринимательской структуры всегда играет, с одной стороны, несколько подчиненную роль; с другой стороны, эта система пронизывает организацию во всех точках ее пространства и взаимосвязана со всеми остальными системами предпринимательского формирования.

Комплексные системы создания и эффективности управления организационными знаниями (ССУОЗ) ориентированы не только на манипулирование и движение организационных знаний, но и на обеспечение всех условий для возникновения $\mathrm{y}$ сотрудников, принимающих решения в

1 Гольдштейн Г. Я. Знание как стратегический ресурс фирмы. URL: http:/ /bigc.ru/publications/other/km/ 
предпринимательских структурах, потокового состояния сознания. Потоковое состояние сознания позволяет управленцам лучше сконцентрироваться на решаемых вопросах. Высокий уровень сконцентрированности позволит управленцу определить имеющиеся возможности (которые, гипотетически всегда есть). Это может быть либо возможность разрешения какой-то проблемной ситуации, либо открывающаяся перспектива. Сопоставление этих возможностей и действительной реальности создает возможности разработки программы действий для устранения имеющегося разрыва. Реализация программы действий подразумевает создание соответствующих организационных подсистем, на которые, действуя, ориентируются субъекты управления предпринимательского формирования. Их действия с учетом динамики ситуации оказывают влияния на действительную реальность. Завершает цикл полученный результат, который в сознании человека оказывает свое влияние в трех измерениях: полученный опыт (изменение набора имеющихся знаний и навыков), изменение ментальных моделей, изменение эмоционального состояния субъекта. В частности, если использовать терминологию П. Сенге, можно выделить следующие причинные циклы:

дисциплина «индивидуальное обучение» и базы знаний развивают набор знаний и навыков субъекта;

дисциплины «групповое обучение», «корректировка интеллектуальных моделей» и «общее видение» оказывают влияние на набор ментальных моделей субъекта и его эмоциональное состояние.

В комплексе эти циклы приводят к тому, что субъект получает возможность лучше сконцентрироваться на анализируемой ситуации, а лучшая концентрация позволяет выделить больший набор возможностей из потенциально имеющихся в ситуации. И цикл повторяется заново и заново, что приводит к прогрессивному развитию как самой предпринимательской структуры, так и еe структуры управления.

Но как организация создает новое знание, что делает возможным его создание? Обратимся к авторам, исследовавшим этот феномен, - И. Нонаке и Х. Такеучи. Согласно их точке зрения теория создания организационного знания предпринимательской структурой базируется на двух аспектах создания знания организацией: эпистемологического и онтологического (рис. 1.10).

Эпистемологический аспект, показанный на оси ординат, отражает процесс трансформации знания из неформализованного в формализованное, и наоборот. Авторы выделяют четыре способа этой трансформации - социализацию, экстернализацию, комбинацию и интернализацию. Все они зависимы друг от друга, и их взаимодействие во времени (третьем измерении) образует трехмерную спираль. Ими описано пять организационных условий - намерение, встряску/хаос, самостоятельность, избыточность информации и ее разнообразие, при выполнении которых четыре способа трансформируются в спираль знания.

Онтологический аспект, показанный на оси абсцисс, подразумевает трансформацию знания, созданного индивидуумами, в знании группового и организационного уровней. Уровни эти зависимы друг от друга и находятся в непрерывном взаимодействии. И вновь время выступает в роли третьего измерения, в нашем случае -в пятифазном процессе создания организационного знания: распространении неформализованного знания, создании концепции, ее проверке, построении архетипа и переходе знания на другой уровень. Еще одна спираль разворачивается в онтологическом измерении при развитии знания, 
например, при переходе знания команды разработчиков на уровень отдела, а в итоге на корпоративный или межорганизационный уровень. Пять достаточных условий обеспечат развитие процесса и развертывание спирали.

Эпистемологический аспект

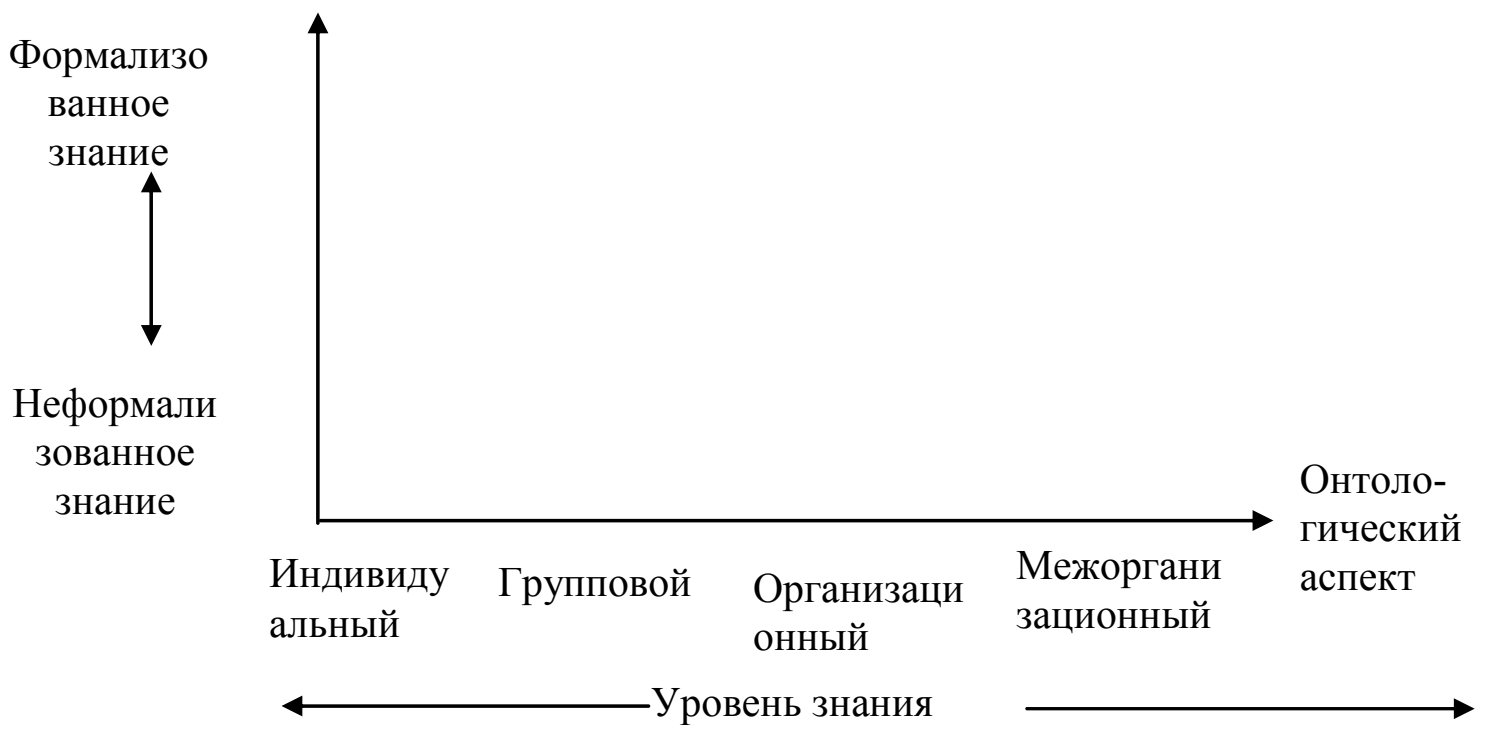

Рис. 1.10. Два аспекта создания организационного знания предпринимательской структурой

Процесс трансформации в пределах двух описанных спиралей знания - ключ к пониманию теории И. Нонаки и Х. Такеучи. «Представьте взаимодействие спиралей в трех измерениях: в эпистемологическом спираль идет вверх, в онтологическом - совершает циклические движения слева направо и опять влево. И, конечно же динамическая природа нашей теории может быть изображена как непрерывное взаимодействие двух спиралей во времени. Инновации - результат такого взаимодействия» ${ }^{11}$.

Для организации процесса создания организационных знаний необходимы специальные технологии. Технология - это набор конкретных средств и строгий алгоритм действий с ними, однозначно определяющий процесс получения результата с заданными параметрами. Поэтому технологичный подход позволяет организовать процесс создания организационного знания с минимальной подготовкой к нему персонала, вовлекать в него многих менеджеров и специалистов, снижать сопротивление при внедрении соответствующих изменений в производство и управление, а главное, обеспечивает его устойчивость и необратимость. Благодаря этому технологично организованный процесс создает организационные знания быстрее, проникает в организационную культуру предпринимательской структуры и вызывает в ней соответствующие изменения. Критериями технологичности являются следующие признаки:

${ }^{1}$ Нонака И. Компания - создатель знания... 
- системная организация и воспроизводимость процесса создания организационного знания;

- управляемость им в целом и на основных этапах;

- алгоритмичность и определенная стандартизированность.

Технологии организации инновационной и обучающей деятельности, в отличие от методов и методик, обладают следующими практическими преимуществами:

- позволяют более стабильно и однозначно достигать поставленных целей, задавая конкретную траекторию инновационного процесса и профессионального роста персонала, обеспечивая при этом четкий план и последовательность действий всех участников;

- легче передаются постоянным пользователям - сотрудникам корпоративного университета с полным сохранением методологической основы и эффективности применения. Это обусловлено тем, что технологии меньше зависят от разработчиков, в них минимизировано влияние личностного фактора на процесс и результат деятельности;

- включают специальные

информационно-методические средства, обеспечивающие однозначность алгоритма действий, которые понятны для тех, кто с ними работает, и могут быть в той или иной части автоматизированы. Подобные технологии проще совершенствовать;

- расширяют масштаб инновационно-обучающей деятельности и вовлекают большое количество сотрудников в решение новых задач в сжатые сроки;

- более полно осознаются и повышают профессиональный интерес у всех участников, так как ориентированы на получение конкретного продукта, имеющего самостоятельное значение для решения производственных задач предпринимательской структуры ${ }^{11}$.

Разрабатываемая в работе ССУОЗ - это метод осуществления целенаправленного создания организационных знаний на основе интеграции всех процессов и ресурсов, необходимых для создания и внедрения новых методов и технологий в рамках одного целостного проекта. ССУОЗ способствует реализации концептуального подхода к инновациям и организации полного цикла действий по их разработке и внедрению.

В современной экономической литературе практически нет методик по оценке нового знания. Широко известные подходы к оценке внедрения нового знания в предпринимательскую деятельность ${ }^{2}$ уже не соответствуют современным условиям, так как не позволяют субъектам предпринимательской деятельности осуществлять эффективную деятельность по производству и внедрению нового знания в производственные процессы. У многих предпринимательских формирований наиболее острой проблемой является необходимость снижения энерго- и ресурсозатрат. Оптимальным и эффективным решением данной задачи является внедрение нового знания, не имеющего аналогов в современной мировой практике и разрабатываемого для каждого субъекта предпринимательской деятельности в отдельности, в зависимости от

${ }^{1}$ Выгодский Л. С. Собрание сочинений: В 6 т. Т. 2. М.: Педагогика, 1982.

2 Адлер Ю., Черных Е. Управление знаниями: новые акценты поиска источников конкурентных преимуществ. URL: http://bigc.ru/publications/other $/ \mathrm{km} /$; Акоф $\phi P$. Акофф о менеджменте. СПб: Питер, 2002; Арсентьев С. Базовые понятия Knowledge Management. URL: http://bigc.ru/publications/other/km/ 
индивидуальных особенностей организации производства. В соответствии с предложенной М. Власовым и Е. Поповым методикой на одном из российских металлургических заводов было проведено исследование, посвященное оценке целесообразности вложений в производство нового знания ${ }^{1}$, которая определяется по формуле

$$
K=\sum_{t=1}^{T} D(t) \cdot(1+\gamma)^{-t+1}
$$

где $K$ - оценка вложений в производство нового знания; $D(t)$-объем вложений в производство нового знания; $T$ - время разработки нового знания; у - ставка дисконтирования.

Доход, полученный в результате использования нового знания, определяется следующим образом:

$$
P=\sum_{t=1}^{T} D(t-\Delta) \cdot(1+\gamma)^{-t+1}
$$

где $P$ - доход, полученный в результате использования нового знания; Д - время реализации.

В рассмотренных выше подходах необходимым условием для определения вложений и доходов, получаемых в результате использования нового знания, является приведение финансовых потоков к начальному моменту времени посредством ставки дисконтирования.

Сравнение объемов вложений и доходов является основой для выработки решения о целесообразности организации деятельности по производству нового знания:

$$
S=K \cdot(1-r)-P
$$

где $S$ - прибыль, полученная в результате использования нового знания; г - оценка рисков неполучения нового знания.

Таким образом, основным условием принятия решения об организации производства нового знания является соотношение

$$
\frac{S}{K} \geq \gamma
$$

${ }^{1}$ Власов M, Попов Е. Оценка использования нового знания // Журнал Управление Компаний. 2005. № 12 (55). 


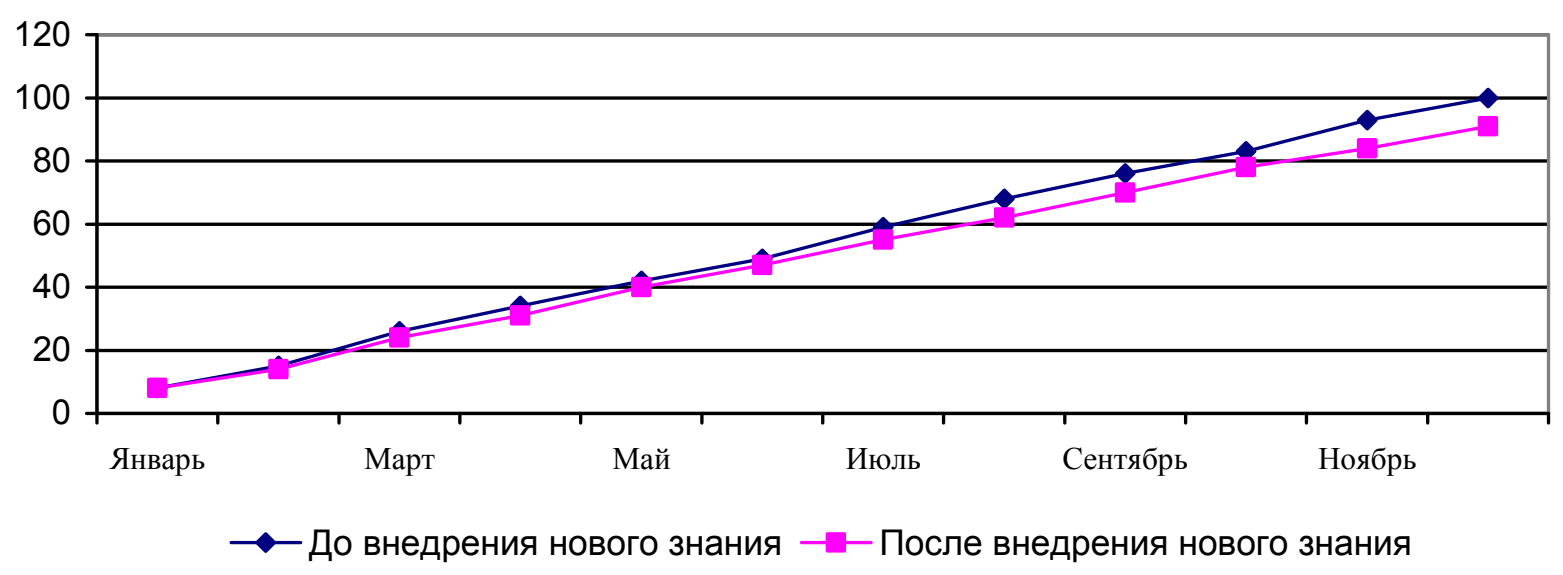

Рис. 1.11. Результаты внедрения нового знания

Целью разработки и внедрения нового знания являлось снижение энергозатрат в нескольких цехах исследованного металлургического предприятия. Результаты, полученные благодаря разработке и внедрению нового знания, представляющего собой систему снижения энергозатрат, даны на рис. 1.11.

Таким образом, оценка целесообразности внедрения нового знания на основе рассмотренной методики позволяет сделать следующие выводы:

1. Организация производства на основе внедрения нового знания дает возможность предпринимательской структуры получить прибыль на уровне не меньше нормы доходности, принятой на хозяйствующем субъекте.

2. Во многих случаях внедрение нового знания приводит к значительной экономии ресурсо- и энергозатрат, что является актуальным для многих субъектов предпринимательской деятельности.

Анализ литературных источников ${ }^{1}$ показал, что правильное развитие ССУОЗ позволяет получить эффекты (табл. 1.6).

Таким образом, потенциальные возможности использования инструментария парадигмы создания и эффективного управления организационными знаниями огромны. Научная и деловая литература «пестрит» примерами кардинальной перестройки модели бизнеса различных предприятий и достижения высоких результатов от реализации этих программ. Однако анализ показывает, что предпринимательские модели хозяйствования и ситуационные особенности подавляющего большинства компаний, описанные в этих примерах, схожи, а количество таких компаний в относительном выражении ничтожно мало. Это говорит о том, что развитие парадигмы чем-то сдерживается. Наши исследования показывают, что причиной замедления развития парадигмы является внутреннее противоречие, которое характерно для многих управленческих парадигм, находящихся на этапе становления. Речь идет о несоответствии универсального характера положений молодой парадигмы управления знаниями объективным и

1 Мариничева M. Управление знаниями: в чем выгода? / URL: http:// bigc.ru/publications/other/km/; Сенге П. Пятая дисциплина: искусство и практика самообучающейся организации. М.: Олимп-Бизнес, 1999; Системы управления знаниями. URL: http://www.pcmag.ru; Альпина Бизнес-Букс, 2006. 
принципиальным различиям организационных моделей разных предпринимательских формирований.

Эффекты от развития ССУОЗ в предпринимательских структурах

\begin{tabular}{|c|c|}
\hline Вид & Содержание \\
\hline Социально- культурны е & $\begin{array}{l}\text { Процесс труда превращается в стимул } \rightarrow \text { более высокий } \\
\text { уровень лояльности персонала } \longrightarrow \text { повышение уровня } \\
\text { соблюдения трудовой дисциплины, общей культуры персонала, } \\
\text { уменьшение частоты и силы деструктивных конфликтов на }\end{array}$ \\
\hline Экономические & $\begin{array}{l}\text { Более высокий уровень лояльности } \longrightarrow \text { снижение количества } \\
\text { брака и ошибок; увеличение производительности труда. } \\
\text { Кардинальное снижение затрат, возникающих в процессе } \\
\text { разрешения проблемных ситуаций. Каскад эффектов, } \\
\text { связанных с реализацией перспективных возможностей } \\
\text { (повсеместное новаторство). Снижение затрат на управление и }\end{array}$ \\
\hline Рыночные & 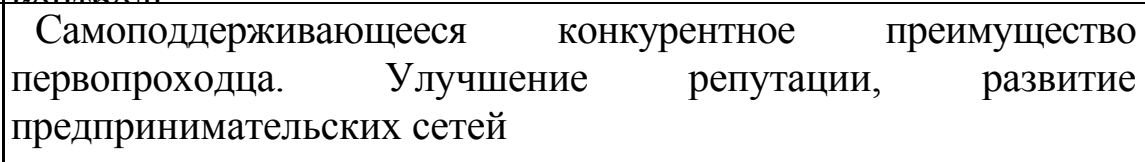 \\
\hline Управленческие & $\begin{array}{l}\text { В основе организационной модели самоорганизация, которая } \\
\text { «сама себя поддерживает и регулирует» } \rightarrow \text { снижение } \\
\text { необходимости управленческого сопровождения }\end{array}$ \\
\hline Операционные & $\begin{array}{l}\text { Система бизнес-процессов становится гибче и постоянно } \\
\text { оптимизируется. В основу системы бизнес-процессов положены } \\
\text { нестандартные решения }\end{array}$ \\
\hline
\end{tabular}

Предпринимательские

модели

хозяйствования

различных

предпринимательских формирований индивидуальны. Это аксиома. В основе каждой предпринимательской модели лежит свой набор объективно существующих причинно-следственных зависимостей (таких, например, как наличие свободной ниши на рынке, или технологические особенности рабочего потока и др.), который качественно отличается от набора зависимостей модели другого типа. Игнорирование этих зависимостей невозможно - необходимо либо их учитывать, либо радикально перестраивать предпринимательскую модель (что означает, как правило, смену не только структуры управления, но и среды обитания предпринимательской структуры). Часто второй путь невозможен, так как предпринимательская модель деятельности обычно является результатом длительного естественного развития. Целенаправленно спроектировать удачную предпринимательскую модель хозяйствования (или, по-другому, морфологию предпринимательства) очень сложно (синергетики, эволюционисты и некоторые другие группы ученых убеждены, что это невозможно).

На современном же этапе становления постановка ССУО3 в предпринимательских формированиях ассоциируется адептами парадигмы создания и эффективного управления организационными знаниями с превращением компании в инновационную фирму, интенсивно и агрессивно реализующую свою инновационную стратегию (примеры реализации именно таких проектов по 
«постановке ССУОЗ» описываются в деловой литературе). С учетом вышесказанного, это возможно только в одном случае: если предпринимательская модель компании изначально является инновационной, а причины низкой результативности коренятся в неэффективной реализации этой предпринимательской модели. Ситуация осложняется также тем, что отсутствуют четкие критерии оценки эффективности управления знаниями в предпринимательских формированиях. Эта сложность имеет объективную причину: результаты внедрения ССУОЗ проявляются опосредованно через улучшение значений показателей результативности и эффективности основной деятельности субъекта предпринимательства. Таким образом, парадигма создания и эффективного управления организационными знаниями на современном этапе своего развития обладает, с одной стороны, значительными достоинствами в виде потенциального существенного улучшения значений показателей эффективности и результативности функционирования предпринимательского формирования, с другой стороны, не обладает развитым, научно обоснованным методическим инструментарием, позволяющем повсеместно реализовывать эти достоинства на практике.

В соответствии с концептуальной моделью С. Галахера и Ш.Э. Хазлет система создания и эффективного управления организационными знаниями включает три основные составляющие ${ }^{1}$ :

1. Инфраструктура знаний: существующие в организации структура и процессы, оказывающие влияние на то, какой будет ССУО3; карта знаний, определяющая нахождение в организации искомого знания. Инфраструктура знаний является структурной основой для ССУОЗ.

2. Культура знаний - корпоративная атмосфера, способствующая или не способствующая созданию новых организационных знаний и обмену знаниями. Культура знаний отражает социально-психологический аспект ССУОЗ.

3. Технология знаний, включающая:

исследования данных и текстов (Data mining, Text Mining) -распознавание образов, выделение значимых закономерностей из данных, находящихся в хранилищах или входных или выходных потоках. Эти методы основываются на статистическом моделировании, нейронных сетях, генетических алгоритмах и др.;

системы управления документооборотом (Document management) -хранение, архивирование, индексирование, разметка и публикация документов;

средства для организации совместной работы (Collaboration) -сети intranet, технологии группой работы, синхронные и асинхронные конференции;

корпоративные порталы знаний;

средства, поддерживающие принятие решений (Decision support) -экспертные системы, системы, поддерживающие дискуссионные группы и т. д.

Но эта система, как и многие другие, не подразумевает создания организационного знания. Среди множества новых управленческих теорий, появившихся в середине 1980-х гг. и проповедующих значение знания для предпринимательских структур и общества в будущем, очень мало исследований, посвященных процессу создания знания как ведущими деловую активность предпринимательскими структурами, так и несколькими организациями совместно. Эти теории рассматривают в основном приобретение, накопление и использование

\footnotetext{
Кудрявиев Д. Многогранность управления знаниями на предприятии. URL: http://bigc.ru/publications/bigspb/km/ mnogogr_uz_na_predpr.php
} 
существующих знаний, игнорируя понятие «создание нового знания».

Таково мнение японских специалистов Н. Икуджиро и Т. Хиротана. Общепризнанные эксперты в области бизнеса, они первыми связали эффективность японских компаний с их способностями к созданию нового знания и использованию его для производства успешных продуктов и технологий. Мы разделяем убеждения этих ученых в том, что создание организационного знания является одним из важнейших источников конкурентоспособности субъектов предпринимательской деятельности.

До сих пор преобладает взгляд на предпринимательскую структуру как на что-то статичное, раз и навсегда устоявшееся. Но, как показывает практика, успехов добиваются только те предпринимательские структуры, которые динамично реагируют на изменившееся окружение и не только эффективно используют информацию и знание, но и создают их, а сотрудники компаний являются активными проводниками инноваций. Только создавая новое знание, новые продукты и новые способы мышления, предпринимательская структура развивает себя путем разрушения существующей системы знания.

Знание создается отдельными людьми, индивидуумами, без которых предпринимательская структура создать новое знание не может. Предпринимательская структура всего лишь поддерживает создателей и обеспечивает им необходимые условия для создания знания. Таким образом, процесс создания организационного знания подразумевает развитие организационными методами знания, созданного индивидуумами, и выделение его в качестве части системы организационного знания. Этот процесс происходит в рамках «сообщества взаимодействия», которое пересекает внутри- и межорганизационные уровни и границы.

\section{4. УПРАВЛЕНИЕ ОРГАНИЗАЦИОННЫМИ ЗНАНИЯМИ СУБЫЕКТОМ ПРЕДПРИНИМАТЕЛЬСТВА}

Термин «управление знаниями» за последние двадцать лет стал одним из фундаментальных в управленческой науке предметом разносторонних исследований, обсуждений, вошел в практику многих как вид управленческой деятельности и даже как новая функция управления ${ }^{1}$.

Как вид управленческой деятельности и специальная функция управление знаниями имеет ряд особенностей. Во-первых, знания являются и ресурсом, и объектом управления практически во всех подразделениях и в рамках всех функций. Например, Б. 3. Мильнер ссылается на результаты обследования более 80 организаций Западной Европы по этой проблеме, 52 \% организаций испытывают трудности в сохранении знаний, возникающих при переводе сотрудников на другие рабочие места или при реорганизации предприятия, 57 \% указали на высокую стоимость ошибок из-за отсутствия знаний в нужное время и в нужном месте. Области применения управления организационным знанием по данным

1 Асаул H. A. Методические принципы институциональных взаимодействий субъектов рынка как открытых «живых» систем в концепции информационного общества. М.; СПб.: «Вольное экономическое общество России», 2004. 
обследований рынков представлены на рис. 1.12 (данные указаны в процентах от общего числа респондентов) ${ }^{1}$.

Во-вторых, управление знаниями непосредственно связано с использованием современных информационных технологий, сети Интернет, других разветвленных и универсальных сетей, позволяющих накапливать и распространять необходимые знания. Системы распространения знания должны не только охватывать и объединять сотрудников предприятия, но и в идеале всех участников рыночной сети. Преимуществом должны пользоваться технологии, способные помочь в этом процессе.

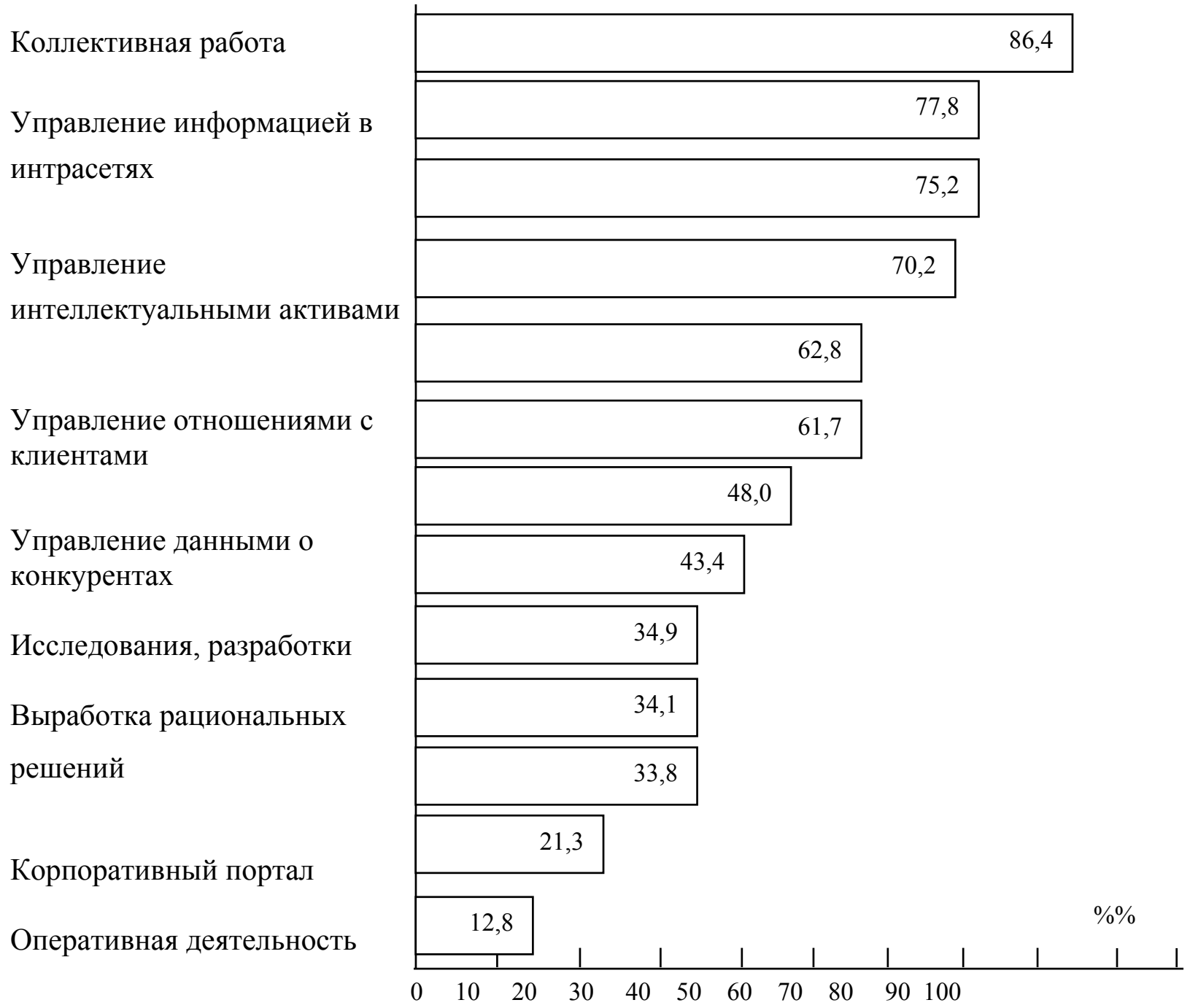

Рис. 1.12. Области применения управления организационным знанием

На это, в частности, указывают результаты опросов (рис. 1.13, данные указаны в процентах от общего числа респондентов) $)^{2}$.

Как и следовало ожидать, наиболее популярными являются такие

${ }^{1}$ Мильнер Б. 3. Теория организаций: курс лекций: учеб. пособие для вузов по спец. «Менеджмент». М.: ИНФРА-М, 1999.

${ }^{2}$ Там же. 
технологии, как Интернет и внутриорганизационные сети. Причем, для коллективной работы программное обеспечение не играет определяющей роли, что подчеркивает значимость коммуникативных потоков и сетей.

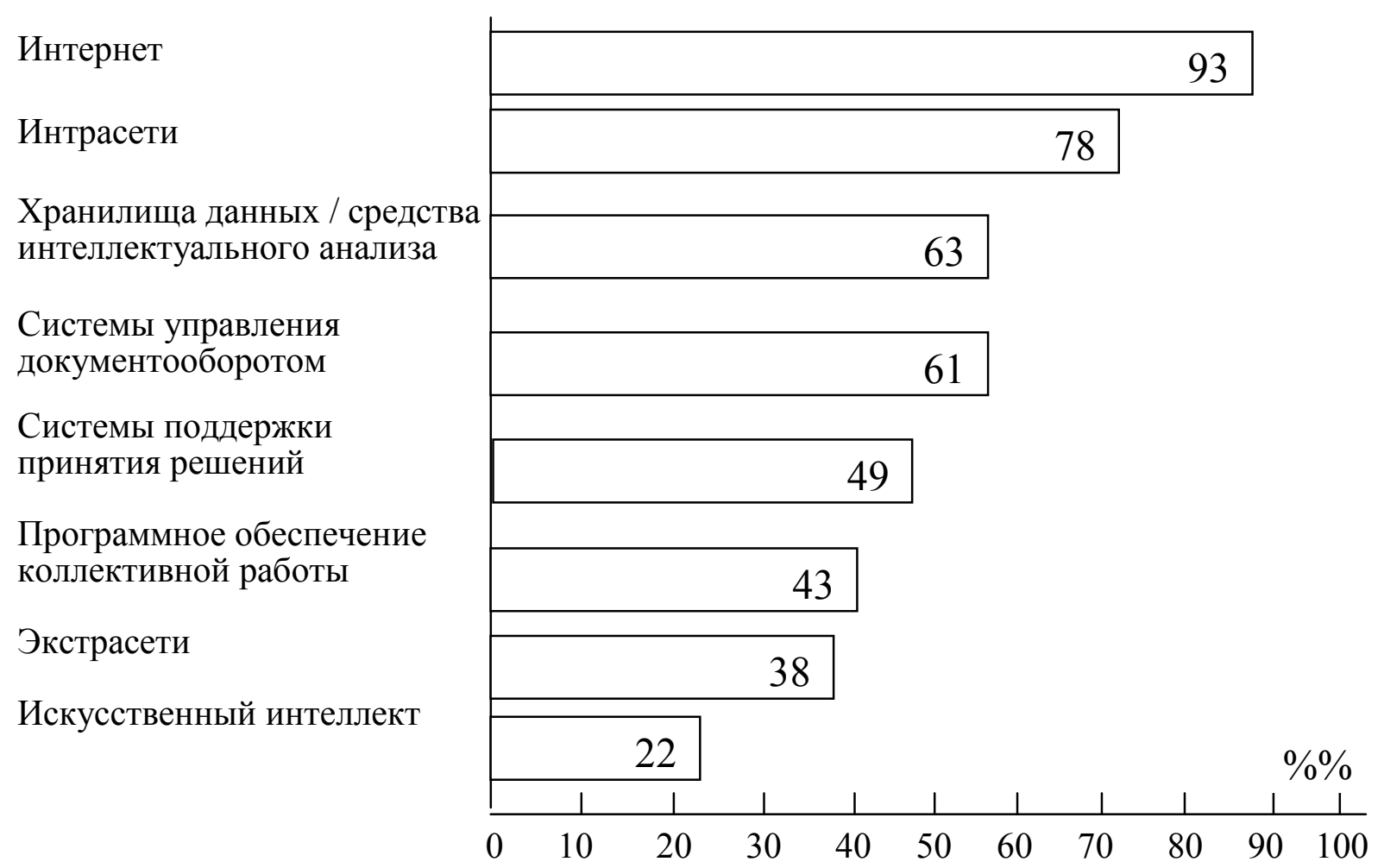

Рисунок 1.13 - Используемые технологии для управление организационным знанием

В-третьих, функция управления знаниями выполняет интеграционную и координационную роль в процессе организационного обучения посредством специальных программ управления знаниями.

O реальных возможностях повышения эффективности производства благодаря осуществлению программ управления знаниями свидетельствуют данные социологических опросов, проводившихся в США в 1998-1999 гг. журналом Management Review, согласно которым более одна треть американских компаний осуществляет программы управления знаниями. Обследованием было охвачено более 1600 управляющих компаниями. Результативность программ по отдельным элементам управления организационным знанием отражена в табл. 1.7.

O влиянии, которое оказали программы управления организационным знанием на основные показатели деятельности компаний, свидетельствует табл. 1.8 .

И, в-четвертых, в качестве важного условия эффективного управления организационным знанием следует считать демократическое управление в предпринимательских структурах. Это означает возможность каждого работника участвовать в формировании корпоративной памяти и осуществлении задач, стоящих перед предпринимательской структурой. Все члены компании должны сознавать, что, 
передавая знания, они способствуют регулированию деятельности предпринимательской структуры, выполняя ее цели и задачи ${ }^{1}$.

Таблица 1.7

Основные элементы программ по управлению организационным знанием

\begin{tabular}{|l|l|}
\hline Мероприятия по управлению знаниями & $\begin{array}{l}\text { Доля } \\
\text { положительных } \\
\text { ответов, \% }\end{array}$ \\
\hline $\begin{array}{c}\text { Управление интеллектуальным капиталом (авторские права, патенты, } \\
\text { лицензии, использование дохода и др.) }\end{array}$ & 72 \\
\hline $\begin{array}{l}\text { Выявление, организация и распространение имеющейся в компании } \\
\text { информации и реальных знаний }\end{array}$ & 75 \\
\hline $\begin{array}{c}\text { Создание климата для распространения, передачи знания } \\
\text { Передача в компанию знаний от акционеров для создания инновационной } \\
\text { корпоративной стратегии }\end{array}$ & 47 \\
\hline
\end{tabular}

Таблица 1.8

Цели и результаты программ по управлению организационным знанием

\begin{tabular}{|l|l|}
\hline Показатель & $\begin{array}{l}\text { Доля } \\
\text { положительных } \\
\text { ответов, \% }\end{array}$ \\
\hline Рост удовлетворенности запросов потребителей & 78 \\
\hline Рост удовлетворенности интересов сотрудников & 60 \\
\hline Инновации в производстве и сервисе & 59 \\
\hline Повышение уровня рентабельности & 56 \\
\hline Повышение уровня годового дохода & 52 \\
\hline Помощь потребителей в достижении позитивных результатов & 45 \\
\hline Сокращение текучести кадров & 37 \\
\hline Снижение потребительских цен & 36 \\
\hline Ускорение выхода на рынок & 30 \\
\hline
\end{tabular}

Особенности экономики, основанной на знаниях, исследованы Н. А. Асаулом ${ }^{2}$. Суть их заключается в следующем:

Во-первых, объективированное в продуктах и услугах организационное знание формирует большую часть создаваемой стоимости. Этот процесс развивается через интеллектуализацию технологий, рост наукоемкости производимой продукции, развитие рынка интеллектуальных товаров и услуг. Главными инструментами конкурентной борьбы в этой ситуации становятся настройка на

${ }^{1}$ Асаул А. Н. Интегративное управление в инвестиционно-строительной сфере. СПб.: Гуманистика, 2006.

${ }^{2}$ Асаул Н. А. Методологические принципы институциональных взаимодействий субъектов рынка... 
потребителя, более полный учет его индивидуальных потребностей, а также постоянное совершенствование бизнес-процессов, что требует эффективного использования информации и знаний как ресурсов субъекта предпринимательской деятельности.

Во-вторых, деятельность, связанная с производством, хранением, передачей и использованием организационных знаний, процессами преобразования информации в знания, приобретает все более существенное значение. Особая роль в этой деятельности принадлежит образованию, характер и значение которого изменяются в наибольшей степени. Начиная с 60-х годов XX века затраты на образование во всех странах растут быстрее, чем в других сферах деятельности. И в современной экономике образование рассматривается как форма инвестиций в человеческий капитал, от которой зависит качество и эффективность производства. Считается, что за весь период профессиональной деятельности (примерно 40 лет) специалист должен повышать свою квалификацию 5-8 раз.

В-третьих, качественные институциональные изменения, влекущие за собой рост трансакционных издержек. Трансакционные издержки - относительно новая экономическая категория, активно введенная в экономический анализ лауреатом Нобелевской премии Рональдом Коузом в 1937 г. Эти издержки связаны не с производством как таковым, то есть расходами на сырье, материалы, оплату труда, транспортировку и т. д., а с затратами, обусловленными поиском информации, изучением рынка, заключением контрактов и контролем за их исполнением, защитой прав собственности и многими другими составляющими. Соответственно возросли требования к эффективности сбора и обработки информации, маркетинговых исследований, рекламы, связей с общественностью, бизнес-разведке и т. д., т. е. к видам деятельности, основными ресурсами которых являются информация и знание. Например, в США на трансакционные издержки приходится более 50 \% общих издержек производства и реализации продукции и услуг ${ }^{1}$.

В-четвертых, значительное возрастание роли менеджмента в области интеллектуальных ресурсов. Об этом можно судить по «цене» мероприятий в области менеджмента изменений субъектов предпринимательской деятельности, широко обсуждаемых в литературе стратегических ошибок, связанных с интеллектуальными ресурсами и продуктами, которые имели самые печальные последствия для совершивших их фирм. То есть, управленческое знание, интеллектуальные ресурсы менеджмента играют не менее важную роль, чем профессиональное знание непосредственных производителей.

И последнее. Известно, что знания и информация устаревают по экспоненциальной кривой, поэтому в условиях постоянного обновления знаний и жесткой конкуренции компании оказываются перед необходимостью постоянного обучения (lifelong learning -обучение в течение жизни). Особая роль в процессе формирования системы создания и эффективного управления организационным знанием принадлежит инновационным корпоративным университетам.

В процессе разработки ССУОЗ следует учитывать аспекты, приведенные в табл. 1.9.

Среди профессионалов существует устойчивое мнение, что в основу ССУОЗ должна быть положена одна из возможных стратегий управления знаниями, основоположниками которых являются Уэн-ди Букович и Руфь Уильяме2:

\footnotetext{
${ }^{1}$ Климов СМ. Интеллектуальные ресурсы общества. СПб.: ИВЭСЭП, Знание, 2002.

${ }^{2}$ Букович У., Уильяме Р. Управление знаниями. М.: ИНФРА-М, 2002.
} 
персонифицирующий или интуитивистский подход. Знание содержится в людях и главное, чтобы носители знания (эксперты) его хранили и им делились. Предпринимательская структура должна знать таких «экспертов» в лицо, всячески лелеять и поощрять (материальная и нематериальная мотивация) этот живой «фундамент своего благополучия». Главное в управлении организационным знанием - это сотрудники, их мотивация, связи, культура компании, а технологии это просто инфраструктура. Нет смысла разрабатывать технологию, пока нет соответствующей культуры. Не надо ставить глобальные задачи, требующие больших ресурсов, а начать с очевидного и легко доступного. Сторонники интуитивистского подхода считают, что при его использовании значительно больше шансов уловить неформальные (скрытые) знания сотрудников (например, их мнения по каким-то производственным вопросам, личные взаимоотношения с клиентами), которых в каждой компании примерно в четыре раза больше, чем знаний, которые можно преобразовать в документы. Этот подход подразумевает непосредственное общение сотрудников и передачу знаний на собраниях, тренингах, мероприятиях типа team building. Кроме того, в компании создаются условия, чтобы сотрудники-лидеры в какой-то области могли делиться опытом с остальными (например, наставничество) и т. д. Таким образом, основная задача управления организационными знаниями - выявление, сохранение и эффективное использование знаний сотрудников.

Таблица 1.9

Основные аспекты ССУОЗ с учетом российской специфики

\begin{tabular}{|c|c|}
\hline $\begin{array}{l}\text { Аспект формирования } \\
\text { ССУОЗ }\end{array}$ & Процессы управления знаниями \\
\hline Стратегия & 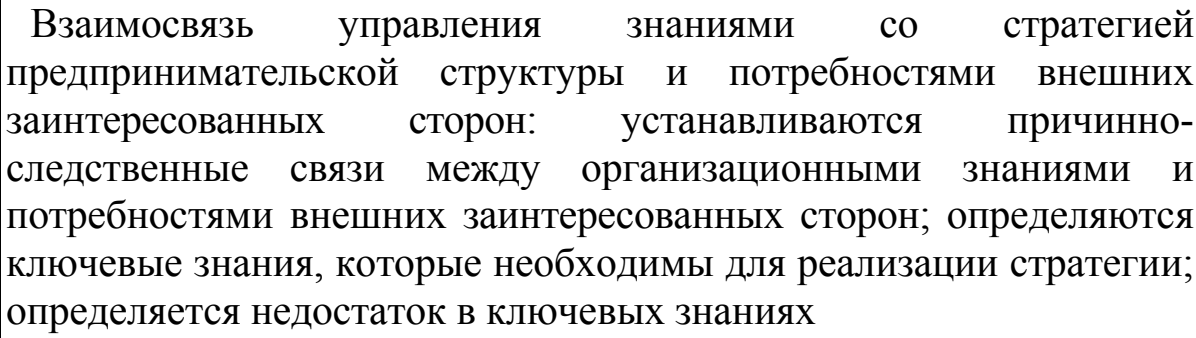 \\
\hline Процедурное знание & 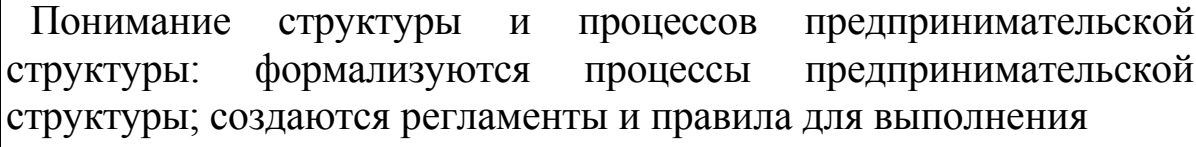 \\
\hline Источники знаний & $\begin{array}{l}\text { Определение знания, необходимого для выполнения процессов, } \\
\text { где оно находится и как распределено в компании: создаются } \\
\text { карты знаний, которые описывают источники как скрытых, так и } \\
\text { явных знаний, а также места использования и создания знаний }\end{array}$ \\
\hline Процессы знаний & $\begin{array}{l}\text { Организация деятельности по управлению организационными } \\
\text { знаниями: создается стратегия управления организационными } \\
\text { знаниями; внедряются новые системы организации сообществ; } \\
\text { разрабатываются процессы управления организационными } \\
\text { знаниями; проводится аудит текущего состояния управления } \\
\text { организационными знаниями }\end{array}$ \\
\hline
\end{tabular}




\begin{tabular}{|c|c|}
\hline Культура & 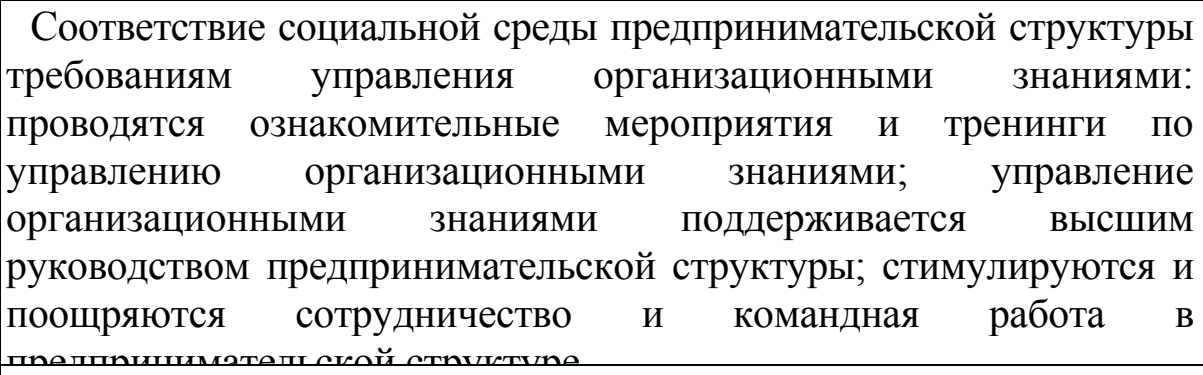 \\
\hline Технология & \begin{tabular}{llll}
\multicolumn{1}{|c}{ Технологическая } & \multicolumn{1}{c}{ поддержка процессов } & управления \\
организационными знаниями: проводится & аудит и оценка \\
информационных & систем управления & организационными \\
знаниями предпринимательской структуры; устанавливается и \\
используется программное обеспечение для управления \\
организационными знаниями (Интранет, Groupware)
\end{tabular} \\
\hline
\end{tabular}

Информационный или технологический подход - это когда предпринимательские формирования, особенно крупные, накопили гигантские объемы данных о клиентах, поставщиках, операциях и многом другом, хранящиеся в десятках операционных и трансакционных систем в различных функциональных подразделениях. В этих базах данных скрыты настоящие сокровища мудрости исчерпывающие знания о клиентах, благодаря знаниям которых можно добиться поразительных успехов в их привлечении и удержании. Но эта ценнейшая информация содержится в огромном количестве независимых друг от друга источников, и ее извлечение для конкретных целей становится в подавляющем большинстве случаев физически невыполнимой задачей. Настоящим «океаном информации» является и Интернет, но эта информация, как и упомянутая ранее, в основном представляет собой необработанные данные, не пригодные для целей анализа. Применяемые сейчас разрозненные информационные технологии: intranet и средства для групповой работы, СУБД и хранилища данных, добыча данных и текста, телеконференции и системы дистанционного обучения гармонично прогрессируют по пути от «простых» вычислительных операций к обработке данных, выявлению скрытых зависимостей и правил, что и понимается под управлением организационными знаниями. Во многих компаниях делается попытка создания единого информационного пространства, в котором для каждого менеджера определяются круг потребностей, права доступа и параметры поиска информации внутри этого пространства.

Обобщенные характеристики обоих типов стратегий приведены в табл. 1.10.

Работа с организационным знанием - непривычная инновационная задача для большинства предпринимательских структур. Поэтому методы и технологии проведения данной работы должны быть ориентированы на максимальное вовлечение управленческого персонала. Организационные знания необходимы для того, чтобы решать производственные задачи - принимать правильные решения и успешно их реализовывать.

Подобные задачи могут относиться к трем видам деятельности:

- выполнение текущей работы;

- решение новых задач, связанных с планомерным развитием производства, его модернизацией и совершенствованием организации работы;

решение задач, являющихся принципиально новыми и требующих таких знаний, которые отсутствуют в корпоративной памяти, а часто и вообще 
неизвестны. Например, радикальное реформирование крупного производства на новых принципах организации ${ }^{1}$.

Рассмотрим технологию управления организационными знаниями, разработанные Л. Гительманом и. А. Исаевым ${ }^{2}$, которая содержит три основных блока, представляющих взаимосвязанные системы управления организационными знаниями и активизации интеллектуального ресурса менеджмента, ориентированные на кажду из этих задач.

Таблища 1.10

Характеристика стратегий управления организационными знаниями ${ }^{3}$

\begin{tabular}{|c|c|c|}
\hline Тип стратегии & Кодификация & лизация \\
\hline $\begin{array}{l}\text { Кон } \\
\text { стра }\end{array}$ & $\begin{array}{l}\text { Позволяет быстро вводить в действие } \\
\text { высококачественные и надежные } \\
\text { информационные } \quad \text { системы } \\
\text { помощью повторного использования } \\
\text { кодифицированных знаний }\end{array}$ & $\begin{array}{lr}\text { Позволяет, } & \text { используя } \\
\text { индивидуальный } & \text { опыт, давать } \\
\text { творческие, аналитически точные } \\
\text { советы по } \\
\text { проблемам }\end{array}$ \\
\hline$\left\{\begin{array}{l}\text { Эконом } \\
\text { модель }\end{array}\right.$ & 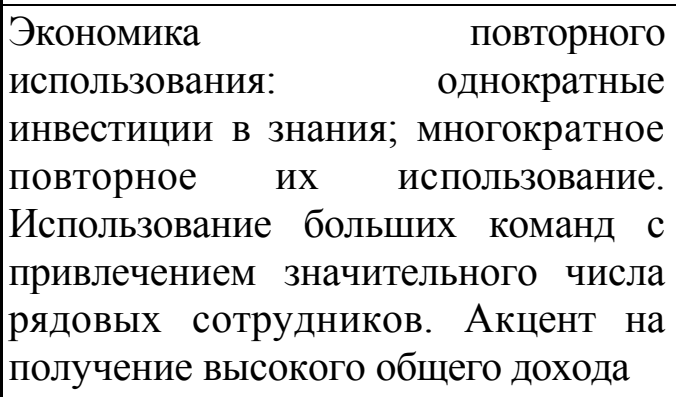 & $\begin{array}{lr}\text { Экономика } & \text { специалистов: } \\
\text { высокая } & \text { оплата } \\
\text { специализированных } & \text { решений } \\
\text { уникальных проблем. } & \text { Создаются } \\
\text { малочисленные } & \text { команды. } \\
\text { Акцент на сохранение } & \text { большого } \\
\text { размера прибыли } & \end{array}$ \\
\hline Двих & $\begin{array}{l}\text { Люди - документы: создание } \\
\text { системы электронных документов, } \\
\text { которая кодифицирует, хранит, } \\
\text { распространяет и и позволяет } \\
\text { повторно использовать знания }\end{array}$ & $\begin{array}{l}\text { От человека }- \text { к человеку: } \\
\text { организация } \quad \text { взаимодействия } \\
\text { среди коллег для передачи } \\
\text { знаний друг другу }\end{array}$ \\
\hline $\begin{array}{l}\text { Инфс } \\
\text { техн }\end{array}$ & $\begin{array}{l}\text { 3начительные } \quad \text { инвестиции } \\
\text { информационные технологии; задача } \\
\text { - обеспечить доступ к } \\
\text { кодифицированным знаниям }\end{array}$ & $\begin{array}{l}\text { Умеренные } \text { инвестиции } \\
\text { информационные в технологии; } \\
\text { задача - обеспечить обмен } \\
\text { знаниями }\end{array}$ \\
\hline Кад] & 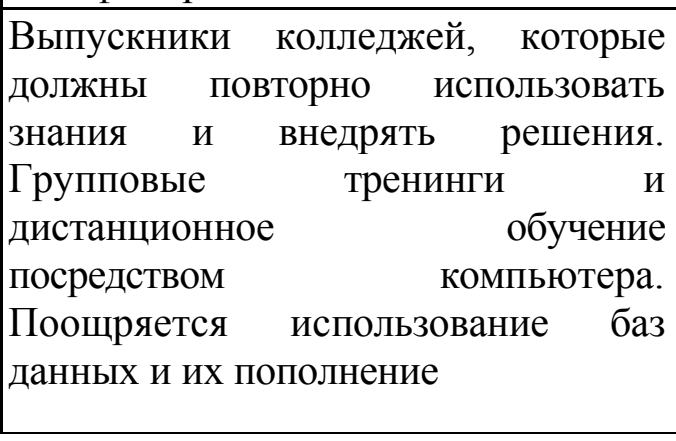 & 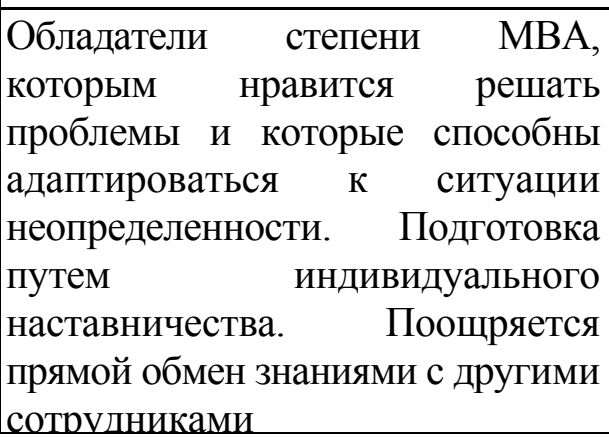 \\
\hline
\end{tabular}

Технология управления организационным знанием создается поэтапно,

${ }^{1}$ Культура организации: проблемы формирования и управления/ А. Н. Асаул и др. СПб.: Гуманистка, 2006.

${ }^{2}$ Гительман Л., Исаев А. Корпоративный университет: технологии работы //Журнал Управление Компанией. 2005. № 10(53).

${ }^{3}$ Хансен $M$,, Нориа Н,, Тирни T. Управляйте знаниями //Организационное обучение. М.: Альпина Бизнес-Букс, 2007. 
начиная с первого блока. Текущая деятельность характеризуется невысокой изменчивостью и высокой регулярностью. Поэтому для повышения эффективности принятия и реализации решений в текущей деятельности менеджерам достаточно системы управления явными знаниями, в основе которой лежит наиболее ценный опыт работы предприятия, представленный в систематизированном виде с помощью компьютерных средств (рис. 1.14, блок А). Основными элементами данной модели являются компьютерная система «Справочник корпоративных знаний (справочник КЗ)» и механизмы оптимизации информационных потоков.

Для решения новых задач менеджеру кроме справочника КЗ потребуется наладить обмен знаниями, позволяющий использовать в процессе принятия решения скрытые знания (собственные и других работников), которые обладают большей эвристической ценностью по сравнению с явными и диалог как форму взаимодействия, активизирующую интеллектуальные способности.

Чтобы управлять скрытыми знаниями и организовывать диалог, нельзя ограничиваться компьютерными средствами: живое межличностное общение между специалистами в большинстве случаев оказывается более эффективным при поиске решения новой задачи.

Поэтому необходима перестройка системы внутренних коммуникаций, которая устранит организационные препятствия для обмена знаниями, минимизирует формальные и неформальные барьеры профессионального взаимодействия, ограничивающие актуализацию скрытых знаний. Данная система включает комплекс специальных средств расширения и оптимизации внутренних коммуникаций, организации заинтересованного обмена знаниями (рис. 1.14, блок Б). Основными элементами данной модели являются комплекс средств активизации формального и неформального взаимодействия между менеджерами и специалистам и компьютерная система обмена знаниями.

Задачи развития и совершенствования управления требуют выхода за рамки существующих организационных знаний. Прежде всего необходимо активизировать интеллектуальный потенциал управленческого персонала для получения новых знаний извне, а также создать организационно-методические средства для самостоятельного генерирования новых идей ${ }^{1}$.

${ }^{1}$ Модернизация экономики на основе технологических инноваций / А. Н. Асаул и др. СПб.: АНО ИПЭВ. 2008. 


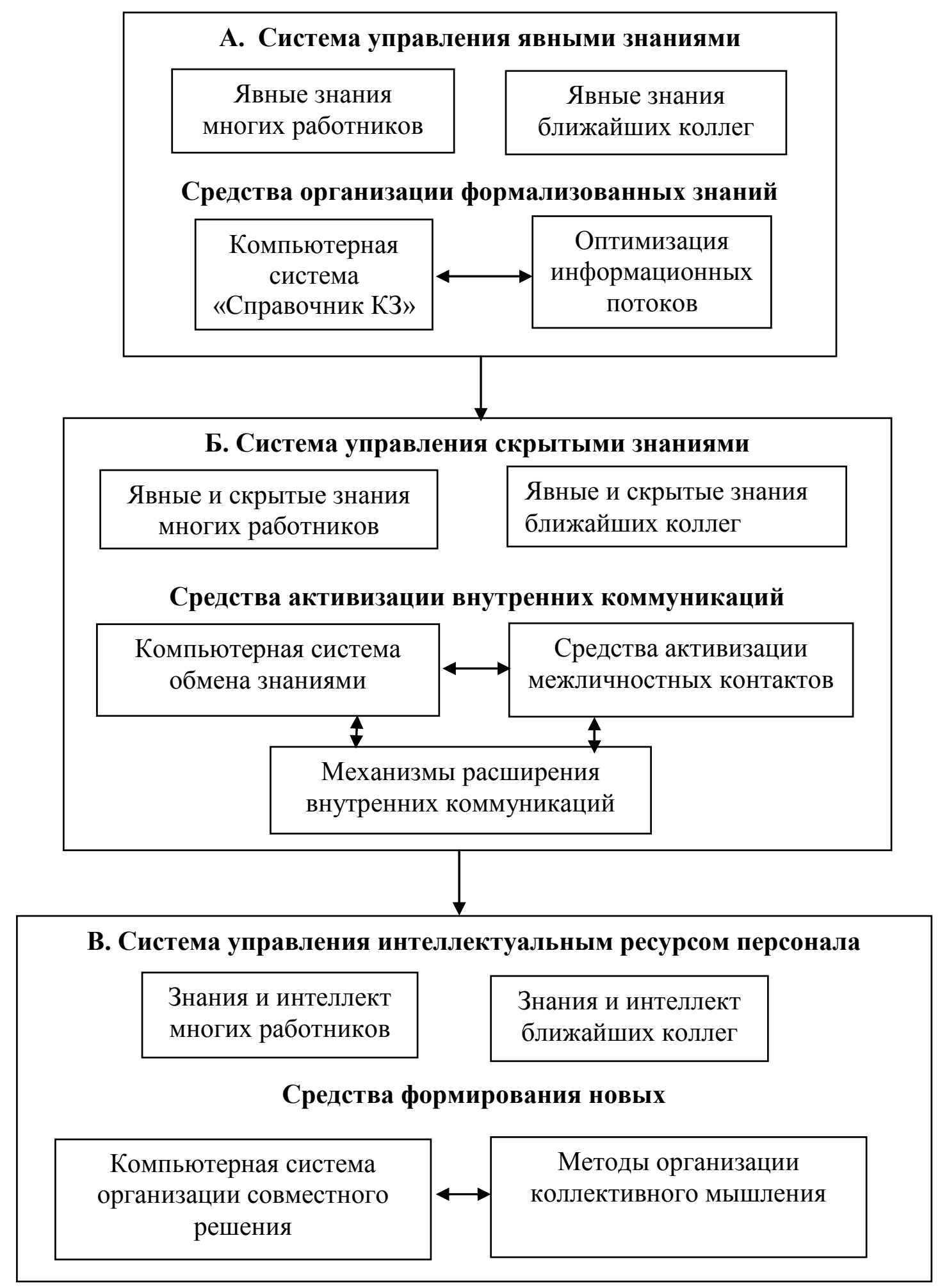

Рис. 1.14. Развитие интеллектуальных систем управления

Получение новых знаний осуществляется с помощью обучающих технологий, включающих самообразование, использование Интернета и других информационных сетей. Для создания необходимых новых знаний внутри компании предлагаются специальные инструменты, позволяющие организовать процесс 
совместного мышления при решении конкретных задач. Применение этих инструментов существенно перестраивает процесс принятия управленческих решений (рис. 1.14, блок В). Основными элементами данной модели являются компьютерная система организации совместного мышления и некомпьютерная система организации коллективного мышления, функционирование которых обеспечивается соответствующими организационными и методическими механизмами. В целом данный блок представляет собой систему управления интеллектуальным потенциалом менеджеров и специалистов.

Создание технологии управления организационными знаниями требует определенных изменений в менеджменте предпринимательской структуры. Внедрение даже самого простого ее вида, справочника знаний, достаточно проблематично при традиционном управлении, где нет, например, информационно-аналитического отдела или структуры внедрения управленческих новаций. Обучающиеся организации через корпоративные университеты решают эту проблему.

Технология корпоративного менеджмент-инкубатора (КМИ) предназначена главным образом для работы с молодыми специалистами предпринимательской структуры.

КМИ, по сути, представляет собой технологию ускоренной подготовки перспективных менеджеров, специалистов и управленческих команд для эффективной работы на реальном производстве. Технология КМИ построена на четырех видах деятельности, комбинация которых обеспечивает эффект интенсивного профессионального развития стажера:

• учебно-проектной;

• производственно-учебной;

- профессионально-познавательной;

- организационно-командной.

Структура КМИ состоит из чередующихся между собой учебно-проектных модулей, производственных стажировок, этапов самостоятельной работы и формирования команды. Кроме того, работа в КМИ включает два завершающих этапа - подготовки и защиты выпускного проекта и конкурса на замещение менеджерской должности.

В организационно-методическом плане весь цикл работы КМИ состоит из пяти стадий, включающих в себя более двадцати конкретных этапов и процедур. Каждая стадия и этап имеют определенное содержание и методическое обеспечение, обусловленные закономерностями процесса становления эффективного менеджера. В несколько сокращенном варианте технологический процесс КМИ представлен на рис. 1.14. Данная технология работы с молодыми менеджерами и специалистами рассчитана на 10-12 месяцев.

Менеджер отрывается от своих производственных функций лишь для работы в учебно-проектных модулях и на производственных стажировках, что составляет примерно четвертую часть всего периода обучения в КМИ. Каждый этап работы продолжительностью от 3 до 12 дней завершается заданием, которое менеджер самостоятельно выполняет на своем рабочем месте под руководством консультантов и наставников. Впоследствии он должен попытаться внедрить разработанные новации в практическую работу.

Технология профессионального развития предполагает активное вовлечение в учебно-практическую работу КМИ топменеджеров и первого руководителя. Как показывает опыт, в результате внедрения КМИ в предпринимательской структуре: 
- растет интеллектуальный потенциал менеджмента;

- формируется команда молодых перспективных менеджеров;

- внедряются новые методы работы в системе управления;

- развивается наставничество;

- снижается текучесть кадров;

• появляются активные точки роста новой корпоративной культуры.

Полный методический пакет, разработанный Л. Гительманом и А. Иссаевым, включает около двадцати специальных технологий. Некоторые из названий, отражающие их функциональное назначение, уже были приведены на рис. 1.12. Часть из них — это собой адаптированные («технологизированные») варианты известных методик, многие являются авторскими разработками.

Основное назначение специальных технологий состоит в повышении инновационной активности при решении конкретных задач, обеспечении устойчивости инновационного процесса на определенных уровнях системы управления и в отдельных сферах деятельности предпринимательской структуры. Применяются они на основе оценки потребности в инновационных решениях и обучении персонала. Поэтому чаще всего специальные технологии используются в виде целевых модулей, выполняющих в комплексе диагностические, инновационные и обучающие функции и, соответственно, состоящие из конкретных технологий трех разных видов.

Серьезной проблемой является внедрение рассмотренных технологий, которое вовсе не сводится к передаче информационно-методических материалов: их нужно «запустить в бизнес-процесс» и поставить в режим стабильного функционирования. Сделать это можно только совместными усилиями менеджеров компании и консультантов, владеющих опытом разработки и внедрения той или иной концепции корпоративного университета и соответствующих технологий.

Выше неоднократно отмечалось, что повышение конкурентных преимуществ субъектов предпринимательской деятельности зависит от постоянного поддержания циклического процесса обновления управленческих систем и развития сотрудников, включающий постановку новых задач, организацию инновационной деятельности, обучение персонала и генерирование новых знаний (рис. 1.15).

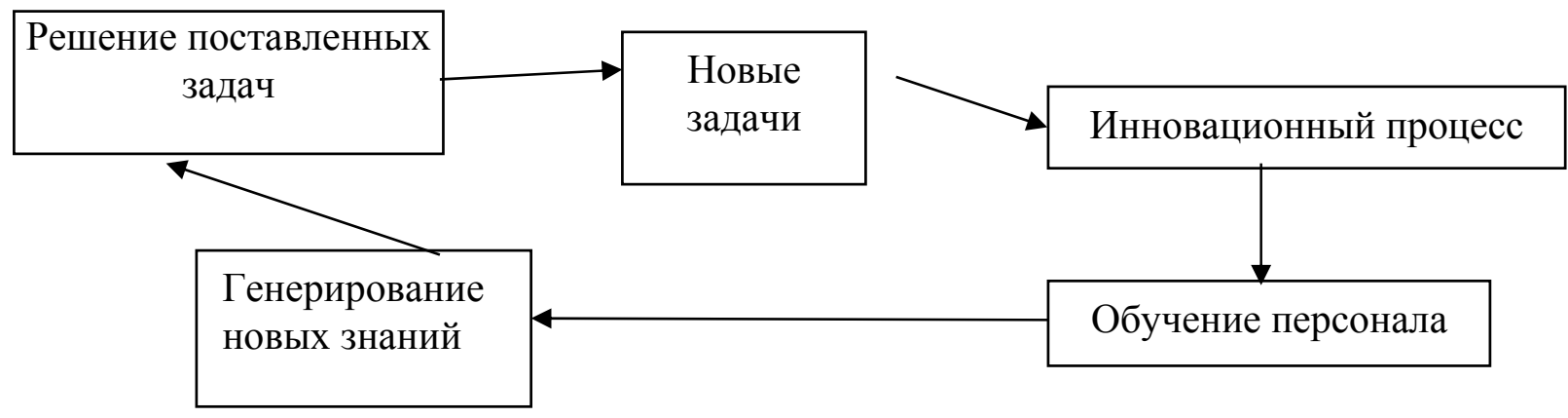

Рис. 1.15. Циклический процесс организационного обновления

Таким образом, актуализируется потребность в новом виде деятельности инновационно-образовательной, которая становится важной частью работы по созданию ССУОЗ. Она включает организацию инновационного процесса, активное 
участие в нем и качественно новое обучение, которое порождает интеллектуальный процесс генерирования, получения и конкретизации новых практических знаний. Такое обучение является поисковым, исследовательским и проектным одновременно.

Разработка инновационных управленческих технологий, новых методов обучения и получение с их помощью новых практических знаний, создание междисциплинарных обучающих программ - взаимосвязанный процесс, который невозможно эффективно организовать без совместного участия специалистов разных «департаментов»: вузовских преподавателей, консультантов консалтинговых фирм и менеджеров-практиков. В то же время организовать инновационнообразовательный процесс в компании учителя они смогут только тогда, если объединят свои усилия, дополняя друг друга знаниями, опытом, идеями.

Реализация данного принципа на практике требует командной работы, методы организации которой - это вопрос для более глубокого рассмотрения. Здесь отметим лишь следующее ${ }^{1}$.

Технология командного обучения менеджеров - это система методик обучения, созданных для организации работы с междисциплинарным содержанием и используемых в разных формах и видах учебной работы: аудиторных занятиях, самостоятельной работе, выполнении заданий на рабочих местах, в типичных и нестандартных ситуациях. Речь идет о методиках учебного проектирования, обучения действием, обучения опытом и др.

Эффективная организация командной учебной деятельности активно способствует превращению междисциплинарного содержания обучения в целостную систему новых знаний, компетенций, в новые мыслительные схемы, подходы, понятия, ценностные ориентации. Полученные в таком процессе новые знания легко переносятся в практическую деятельность и реально применяются в решении производственных задач.

Развитие командного метода проходит ряд этапов - от создания совместной команды менеджеров и учителей до инновационной команды. По мере развития команды меняются акценты в ее деятельности: постепенно наращивается потенциал способности решать более сложные, системные задачи. Причем не просто находить оптимальные решения, но и внедрять их.

${ }^{1}$ Гительман Л., Исаев А. Указ. соч. 


\section{Глава 2 \\ МОДЕЛИ ФОРМИРОВАНИЯ ИНФОРМАЦИОННОЙ \\ ИНФРАСТРУКТУРЫ СУБЪЕКТА \\ ПРЕДПРИНИМАТЕЛЬСТВА}

\section{1. КОНЦЕПЦИЯ ИНФОРМАЦИОННОЙ ИНФРАСТРУКТУРЫ СУБЪЕКТОВ ПРЕДПРИНИМАТЕЛЬСКОЙ ДЕЯТЕЛЬНОСТИ}

Исследование роли информации в хозяйственных и управленческих процессах организации (п. 1.2) позволило сделать вывод об «информационной инфраструктуре» как эволюционной конщепции, то есть разработанных совокупности теоретических представлений и методов структурирования информационных единиц, организации информационных потоков, управления информацией. Но рассмотрение концепций не причина появления информачионной инфраструктуры как явления. Хотя широкое оперирование термином « информационная инфраструктура» в экономической литературе сложилось в последнее время в одноименных концепциях, само явление носит объективный характер по отношению к любой организованной системе. Важность данного положения определяется объективностью исследуемого явления, то есть его реальным проявлением в социально-экономических системах. В первую очередь интересны не научные концепции и методические решения, а наличие предмета исследования, имеющего экономическое содержание. В данном случае требуется продемонстрировать объективность явления - информационной инфраструктуры.

Р. Л. Стратонович ${ }^{1}$ определяет информационную инфраструктуру как «...совокупность единиц сообщений, образующих информационное поле системы». Он дает представление об информационной инфраструктуре как объективной реальности любой организованной системы (рис. 2.1, А). Совершенно аналогичных представлений придерживаются и зарубежные исследователи ${ }^{2}$ M. Buss,

V. Gurbaxani, K. L. Kraemer, J. L. King, S. Jarman, J. Dedrick, K. S.Raman, C S. Yap, T. H. Ho, K. S. Raman, R. T. Watson, F. W. Horton, G. J. Selig. Необходимо отметить, что в большинстве научных публикаций информационное поле и информационная инфраструктура определяются сходно, синонимически. Разделение скорее касается научного контекста: при описании открытых систем используется термин информационное поле (M. Buss), в привязке к закрытым системам информационная инфраструктура ${ }^{3}$.

${ }^{1}$ Стратонович Р. Л. Теория информации. М.: Сов. радио, 1975.

${ }^{2}$ Buss M. Managing International Information Systems, Harvard Business Review, 60, 5, 1982; Gurbaxani $V$. and Government as the Driving Force Toward the Information Society: National Computer Policy in Singapore/ The Information Society, 7, 1990; Ho T. H., Raman K. S. and Watson R. T. Group Decision Support Systems: The Cultural Factor. In J. I. DeGross J. C, Henderson and B. R. Konsynski (Eds.) Proceedings of the 10th International Conference on Information Systems, Boston: MA, 1989; Horton F. W., Jr. Viewpoint. The Information Management Communities on Five Continents, Information Management Review, 5,4, 1990; Selig G. J. A Framework for Multinational Information Systems Planning, Information and Management, 5, 1982.

${ }^{3}$ Rotenberg M. Privacy and the National Information Infrastructure // EDUCOM Review 29 (March/April) 1994. 
Понимая субъект предпринимательской деятельности как социальноэкономическую систему (вне зависимости от типа экономических отношений в ней проявляемых) можно отнести на них вышеприведенное описание, т. е. информационная инфраструктура - это совокупность единиц и потоков информации, образующие информационное поле системы. Не требует развернутой дискуссии и подтверждения тезис о том, что в окружении любой социально-экономической системы существовало и существует информационное окружение, то есть информационная инфраструктура.

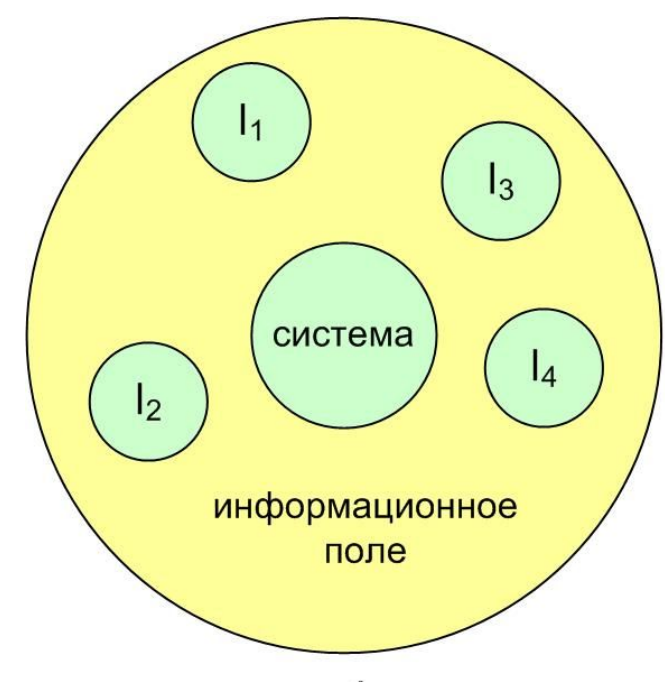

A

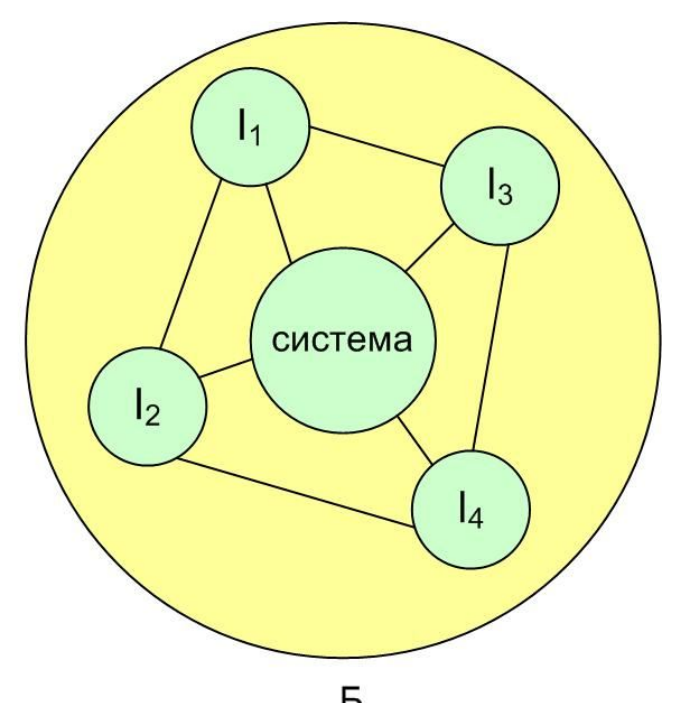

Б

Рис. 2.1. Представление об информационной инфраструктуре неорганизованной (А) и онтологически структурированной (Б): I - единицы информации и информационные потоки.

Если информационное поле, организованное по какому-нибудь принципу, управляется, его можно обозначить как онтологически структурированное Selig G.J. ${ }^{1}$ (рис. 2.1 Б). Принцип структурирования и выражается теоретической концепцией. Заметим, что в рамках исследования научных этапов эволюции роли информации (п. 1.1) рассматривались и другие концепции структурирования информационного поля, инфраструктуры - «внутренней информационной системы субъекта предпринимательства» и «сетевой». Именно это позволяет нам заключить, что концепция организации информационного поля системы, именуемая «концепцией информационной инфраструктуры», является частным случаем выражения принципов структурирования информационных единиц и потоков. А информационная инфраструктура в наиболее общем виде понимается как объективное явление, выраженное в совокупности информационных единиц $и$ потоков, принадлежащих (относящихся) к организованной системе. Определение не включает наличие структурирования поля, инфраструктуры. Объективно рассуждая (см. рис. 2.1), оно может и не быть структурированным, организованным, взаимосвязанным, при этом не выпадая из отнесения к объективным социальноэкономическим явлениям. Перед нами стоит задача исследования именно концепции информационной инфраструктуры, ее научного развития, воплощения в методические механизмы повышения эффективности информационного поля

${ }^{1}$ Selig G. J. A Framework for Multinational Information Systems Planning // Information and Management. 1982. № 5. 
субъектов предпринимательской деятельности.

На первом этапе исследования теоретических основ концепции информационной инфраструктуры выявляем предпосылки eе возникновения. Впервые термин «информационная инфраструктура» появился в рамках концепции, выражающей принципы и методы упорядочивания (структурирования) информационных потоков, окружающих индивидуума или субъекта предпринимательской деятельности (организацию), социально-экономическую систему. Предложенный подход был «...направлен на повышение упорядоченности информационного пространства, а сама информационная инфраструктура рассматривалась как механизм отсечения шума в потоках управленческой информации», не акцентировались на предпосылках и актуальности концепции, заявляли ее как «новое методическое решение, механизм управления информационным пространством». Но, в рамках научного исследования необходимо уточнить предпосылки ее возникновения, предпосылки, объясняющие генезис научных взглядов, актуальность их в контексте как современного развития социально-экономических систем, так и методов информационных технологий, направленных на онтологическое структурирование информационного поля.

Таблица 2.1.

Данные НИИУ ВНИЦ по факторам группы предприятий (1996-2008 гг., У).

Обозначения по табл. 2.2

\begin{tabular}{|c|c|c|c|c|c|}
\hline $\mathrm{y}$ & $Q$ & $D P$ & $I F O$ & $I F I$ & $S$ \\
\hline 1996 & 132,50 & 4568 & 654 & 9876 & 15098 \\
\hline 1997 & 134,60 & 5162 & 789 & 11345 & 17296 \\
\hline 1998 & 149,50 & 5214 & 1267 & 13456 & 19937 \\
\hline 1999 & 103,40 & 5344 & 1187 & 13889 & 20420 \\
\hline 2000 & 112,50 & 6756 & 2238 & 14319 & 23313 \\
\hline 2001 & 117,40 & 6873 & 6578 & 15992 & 29443 \\
\hline 2002 & 118,50 & 7234 & 6645 & 19456 & 33335 \\
\hline 2003 & 122,70 & 7856 & 8765 & 22678 & 39299 \\
\hline 2004 & 112,70 & 9567 & 12987 & 29413 & 51967 \\
\hline 2005 & 99,30 & 11678 & 18654 & 36345 & 66677 \\
\hline 2006 & 98,60 & 11789 & 22345 & 44563 & 78697 \\
\hline 2007 & 105,40 & 12874 & 23119 & 56789 & 92782 \\
\hline 2008 & 103,20 & 14768 & 24567 & 67589 & 106924 \\
\hline
\end{tabular}

Наиболее значимой предпосылкой возникновения концепции информационной инфраструктуры определяем экспоненциальный рост объемов информационных потоков в период 2000-2004 гг., вызванный развитием сетевых, инфокоммуникационных, телекоммуникационных и вычислительных технологий в современной социально-экономической среде. Количественный рост объемов информации привел к невозможности ее обработки в рамках традиционных инструментов и методов информационных технологий, т. е. проявился диалектический принцип «перехода количественных изменений в качественные», знаменующий давно обсуждаемый в научной литературе «информационный кризис» 1 .

${ }^{1}$ Kimura F., John J. Information Infrastructure Systems for Manufacturing II // IFIP Intentional Working Conference on the Design of Information Systems for Manufacturing, Mille, Kluwer Academic Pub, 1999. 
Для демонстрации данной ситуации обратимся к статистическим данным НИИУ ВНИЦ ${ }^{1}$ (табл. 2.1) по группе предприятий «Рестэк» (медиа и консалтинговая деятельность, Санкт-Петербург).

Структура наблюдаемых ВНИЦ факторов по группе предприятий в 1996-2008 гг. представлена в табл. 2.2. В исследование включена количественная оценка традиционного внутреннего (бумажного) документооборота, внутренних и внешних электронных файлов.

Таблица 2.2

Исследуемые факторы, фиксируемые НИИУ ВНИЦ по группе предприятий «Рестэк» (1996-2008 гг., У)

\begin{tabular}{|c|l|}
\hline$Q$ & $\begin{array}{l}\text { Объем продаж по отношению к } 1995 \text { г. (100). Введены коэффициентные } \\
\text { поправки на инфляцию и стоимость валют при продаже услуг зарубежным } \\
\text { контрагентам }\end{array}$ \\
\hline$D P$ & $\begin{array}{l}\text { Документы в «бумажном» архиве, ед. Регистрируемый } \\
\text { документооборот, охватывает 90 \% (экспертная оценка) движения } \\
\text { сведений на бумажном носителе }\end{array}$ \\
\hline$I F O$ & $\begin{array}{l}\text { Электронные файлы, сгенерированные организацией, ед. Учитывается как } \\
\text { внутренний источник сгенерированных сотрудниками организации } \\
\text { электронных файлов }\end{array}$ \\
\hline$I F I$ & $\begin{array}{l}\text { Электронные файлы, поступающие из внешней среды, ед. } \\
\text { Регистрируемый входящий информационный поток. Отфильтрован по } \\
\text { файлам недокументального характера (программное обеспечение и т. п.) }\end{array}$ \\
\hline$S$ & $\begin{array}{l}\text { Итого (DP + IFO + IFI) документов во внутреннем обороте компании, } \\
\text { ед. }\end{array}$ \\
\hline
\end{tabular}

Бумажный документооборот фиксировался по регистрационным записям административной службы, а файлы - сетевыми серверами субъекта предпринимательской деятельности. Совокупность данных единиц информации можно определить как формализованное (документированное) информационное поле компании. Целью мониторинга определен поиск взаимосвязи между объемами хозяйственной деятельности субъекта предпринимательской деятельности и информационными потоками. Для данной коммерческой организации показателем, характеризующим объем хозяйственной деятельности, был определен объем продаж продукции.

Логично можно предположить, что для коммерческой организации доминантным фактором, вызывающим рост объемов информационных потоков, является объем продаж продукции (при однородной продукции, равномерном распределении объема продаж в рамках численности контрагентов):

$$
I F O+D P=f(\mathrm{Q})
$$

${ }^{1}$ НИИУ ВНИЦ выполняет архивную и методическую функции по документообороту в рамках группы предприятий, реализует мониторинг движения информационных потоков. 
Рост объемов договоров, платежных поручений, координационных и логистических документов, численность персонала и подразделений и т. п. определяются ростом числа контрагентов (покупателей), оборотом коммерческой организации. Данное предположение также основывалось на научных выводах Е. А. Игнатьевой, обосновывающей позицию о генерации базовых информационных потоков в рамках взаимоотношений с клиентами компании (CRM) ${ }^{1}$. Именно поэтому сопоставление динамики финансового оборота организации с объемом информационных потоков должно определяться наличием математически оцениваемой корреляционной взаимосвязи (2.1). В соответствии с заданной (см. табл. 2.2) структурой была предоставлена количественная информация, удовлетворяющая обозначенным условиям научного эксперимента.

Анализ полученных данных (см. табл. 2.1) рассматривался как с помощью диаграммы (рис. 2.2), так и в рамках оценки попарной корреляционной взаимосвязи.

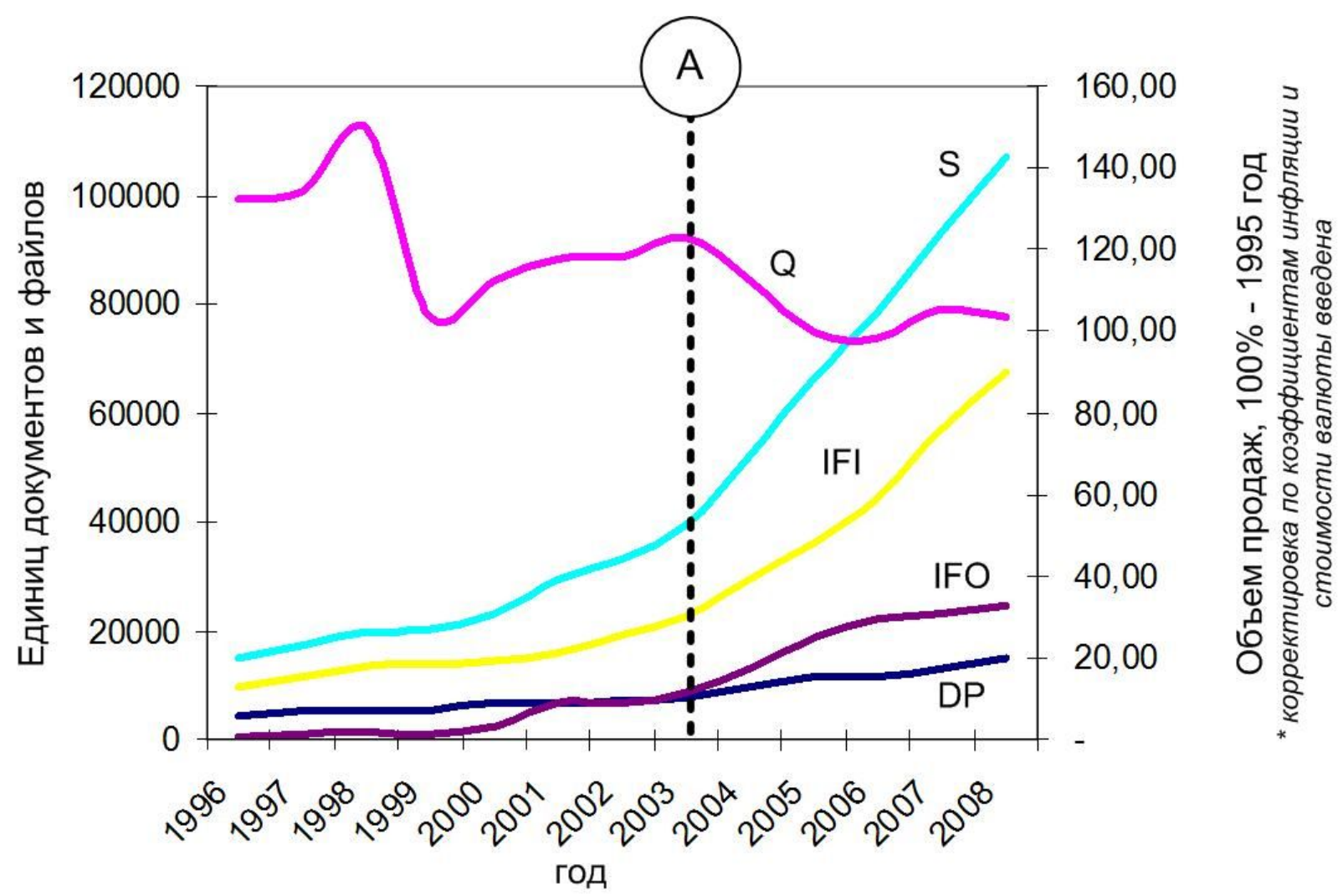

Рис. 2.2. Динамика документированных информационных потоков группы предприятий «Рестэк» (1996-2008 гг.), по данным табл. 2.1

Анализ динамики формализованных информационных потоков «Рестэк», представленной на рис. 2.2, позволяет сделать ряд очевидных выводов и предположений:

1. Показатель хозяйственной деятельности, объем продаж, (равно как и исследованные факторы внутренней организационной среды: численность работников, структура подразделений и т. п.) не имеют выраженной взаимосвязи с

${ }^{1}$ Игнатьева E. A. CRM-системы в информационной инфраструктуре компании, корпоративные финансы. М., 2007. 
объемами информационных потоков. На рис. 2.2 отчетливо видно, что на фоне стагнации (колебание в пределах 20 \%) объемов продаж (Q) происходит значительное увеличение объема информационных потоков (S).

2. Наибольший объем информационных единиц в организации поступает из внешней среды, сетевых источников (IFI, являясь определяющем в суммарном информационном поле организации (S).

3. Экспоненциальный скачок прироста информационных потоков приходится на период 2002-2004 гг. - период «расцвета сетевых информационных ресурсов (интернет, глобальные сети)» ${ }^{1}$, период активного вхождения организаций в сетевые объединения.

4. Логично предположить, что существует объективная взаимосвязь между ростом внешней сетевой информации (IFГ) и ростом внутреннего документооборота как в электронном (IFO), так и вторично в бумажном виде (DP, рис. 2.2). То есть, рост объемов сетевой информации вызывает не только приток первичной внешней информации, но и индуцирует рост вторичной внутренней информации.

Представленная на рис. 2.2 картина взаимосвязи факторов хорошо объясняется взаимодействием внутренних и внешних информационных потоков и незначительно связана с показателями объемов хозяйственной деятельности. Причем приведенная статистика для «Рестэк» не является уникальной и исключительной. Аналогичная ситуация наблюдается и в комплексах ЗАО Лесинформконсалт, ЗАО Мегастиль, ООО Леноблзем, ООО АББА, АНО ИПЭВ и другие; общий объем наблюдений 16-ти предприятий за 1997-2008 гг. 278 статистических позиций). Статистика «Рестэк» приведена в работе как наиболее показательная с точки зрения описания взаимосвязи исследуемых факторов.

Для обоснования выдвинутого положения (п. 4) проведен корреляционнорегрессионный анализ факторов и переменных табл. 2.2. Результаты оценки попарной взаимосвязи (кросс-корреляции) представлены в табл. 2.3.

Таблица 2.3

Исследование кросс-корреляции (R2) факторов

\begin{tabular}{|c|c|c|c|c|c|}
\hline & $Q$ & $D P$ & $I F O$ & $I F I$ & $S$ \\
\hline$Q$ & 1,000 & 0,712 & 0,700 & 0,635 & 0,669 \\
\hline$D P$ & 0,712 & 1,000 & 0,985 & 0,973 & 0,989 \\
\hline$I F O$ & 0,700 & 0,985 & 1,000 & 0,959 & 0,983 \\
\hline$I F I$ & 0,635 & 0,973 & 0,959 & 1,000 & 0,994 \\
\hline$S$ & 0,669 & 0,989 & 0,983 & 0,994 & 1,000 \\
\hline
\end{tabular}

${ }^{1}$ Инфокоммуникации XXI века/ Компания ТрансТелеКом. М.: Междунар. акад. связи, Т. 2. Л. E. Варакин. Информационно-экономический закон. Взаимосвязь инфокоммуникационной инфраструктуры и экономики. 2006. 


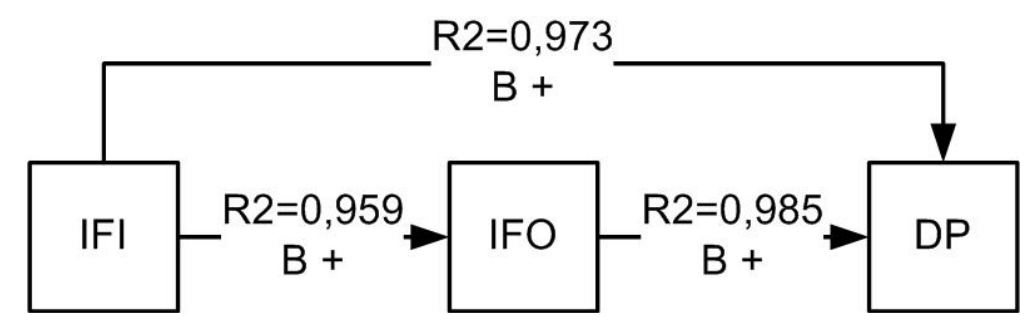

Рис. 2.3. Регрессионные зависимости в информационных потоках (обозначения по табл. 2.2, коэфф. по табл. 2.4)

Результаты регрессионного анализа показали, что все виды информационных потоков имеют высокий коэффициент корреляции (R2), то есть их количественное значение линейным образом взаимосвязано. Причем расчет коэффициентов детерминации (B) показал зависимость объема бумажного документооборота (DP) как от внутреннего объема циркулирующей в организации электронной документации (IFO), так и от объема внешних информационных потоков (IFI), рис. 2.3 .

В свою очередь, объем генерируемых организацией электронных документов зависит от объема внешнего информационного потока. Очевидная математически обнаруживаемая зависимость позволяет сделать вывод, что объем внутреннего документооборота организации определяется размерностью внешнего информационного поля, отменяя логику формулы:

$$
I F O+D P=f(I F I)
$$

Действительно, наличие доступного информационного поля организации позволяет сотрудникам легко создавать внутренние документы, опираясь на содержательный контекст внешних источников. Далее документ для регистрации распечатывается, превращается в бумажный вид, дубликат на бумажном носителе.

Смоделируем пояснительную ситуацию. Например, сотруднику поручено узнать закупочные цены на материалы. Он с помощью внешних сетей (интернет, специальные отраслевые информационные сети) копирует на свой компьютер (поток IFI) прейскуранты поставщиков (положим их три) и компилирует сводный документ (поток IFO), распечатывает его и создает сопроводительный документ (поток $D P$ ). Таким образом, в информационное поле организации попадает 3IFI, 2IFO, 2DP, итого 7 единиц информации. Причем внешняя информация (3IFI) в очень короткий срок устаревает, теряет актуальность, превращаясь в «паразитную» информацию в информационном поле организации, так как информационные ресурсы организации по-прежнему продолжают ее обрабатывать (хранить, архивировать и т. п.), а также к ней могут обращаться и другие сотрудники организации. Более того, в развитие модельной ситуации: если другой сотрудник выполнит те же самые действия (например, для проверки сводного документа), то получим уже дублирование информационных потоков в информационном поле организации. Та же ситуация при отсутствии внешних информационных сетей выглядит следующим образом. Сотрудник с помощью телефона (другой формы личного контакта) получает информацию о ценах, интерпретирует в сводный и сопроводительный документ. 
Общий объем формализованной информации в поле $2 I F O, 2 D P$, итого четыре единицы информации. Данные упрощенные ситуации демонстрируют вывод о том, что экспоненциальный рост объемов информации в организации определяется информационными сетями, ростом их емкости и доступности. При этом в рассматриваемые моделируемые ситуации не включены естественные побочные факторы процесса сбора информации: недостоверность поступающей информации, объем промежуточных изучаемых документов, дублирование, поступление побочных информационных массивов и т. п. факторы, значительно увеличивающие количество внешних сведений «насыщающих» информационное поле организации. Соответственно, имеем ситуацию значительного роста информационных потоков, не обоснованную пропорциональным изменением хозяйственной и управленческой практики субъектов роста, приводящего к информационной неопределенности как следствие росту трансакционных расходов на поиск и обработку информации.

Вывод о зависимости роста информационного поля субъекта предпринимательской деятельности от объемов внешних сетей находит свое подтверждение в исследованиях других ученых. А. В. Бойченко, Е. Н. Филинов, Н. С. Мардер, В. А. Козлова, Е. Monteiro приходят к аналогичным выводам о взаимосвязи между объемами внешних сетевых источников и внутренними информационными потоками субъекта предпринимательской деятельности. «...Развитие объемов информационных потоков организации во многом, если не полностью, определяется развитием информационных сетей... Причем данный рост плохо согласуется с темпами изменений производственной и сбытовой деятельности... Необходим качественно новый подход к организации информационного пространства» ${ }^{1}$.

Итак, первой предпосылкой, определяющей актуальность перехода от сетевой концепции субъекта предпринимательской деятельности к более строгим методам структурирования, является необоснованный по отношению к темпам изменения хозяйственной деятельности рост объемов информационных потоков субъекта предпринимательской деятельности, вызванный сетевым характером организации внешних источников информации.

Второй предпосылкой является отсутствие концептуального единства в средствах обработки информационных потоков субъекта предпринимательской деятельности, сложившееся в настоящее время. Происходит подмена теоретических понятий: концепции автоматизации понимаются как принципы организации информационного пространства субъекта предпринимательства. Возможности вычислительной техники принимаются как граница возможностей обработки информационных потоков. Причиной такого явления является отсутствие адекватных теоретических концеппий информационного пространства субъектов предпринимательской деятельности, построенных на теории информационных технологий. Этот пробел легко заполняется коммерческими компаниями, разработчиками и продавцами компьютерного программного обеспечения. Они позиционируют свое программное обеспечение как комплексные информационные решения для субъектов предпринимательской деятельности (фрагмент из сотен предложений):

«...Ключевое решение для реализации концепции управления эффективностью (субъектов предпринимательской деятельности -aвm.) (Corporate Performance Management, CPM), охватывающей основные процессы управления и дающее

${ }^{1}$ Козлова В. А. Становление системы информационной инфраструктуры как предпосылка развития российского народного хозяйства: автореф. дис. ... канд. экон. наук: 08.00.01. Ростов н/Д, 2007. 
быструю отдачу...»

«...Система управления на платформе Tivoli Enterprise обеспечивает комплексное управление всеми компонентами информационной системы, техническими, сетевыми средствами, системным программным обеспечением, приложениями и позволяет обеспечить работу всей инфраструктуры информационных технологий предприятия...»

«...Система САПЕРИОН - платформа для организации электронных информационных ресурсов и эффективного управления ими в масштабе организации...»

Хотя по факту существующие предложения - не более чем решения по автоматизации отдельных операций хозяйственной и управленческой деятельности, документооборота (полный критический анализ представлен в работе Э. А. Ярных ${ }^{1}$. В большинстве случаев концепции ERP, CRM, DSS${ }^{2}$ и другие являются ничем иным, как подходом к упрощению и редуцированию сложных механизмов информационного взаимодействия субъектов во внутреннем и внешнем пространствах организации. Поскольку ни одна система автоматизации не может (и не должна) «отразить» всю полноту связей такой сложной системы, как субъект предпринимательской деятельности (организация), создатели программного обеспечения сознательно упрощают модели информационного поля, продавая их как «комплекснье информачиинные решения». Происходит сознательная подмена моделей информационного поля конкретного субъекта предпринимательства некой упрощенной универсальной схемой разработчика программного обеспечения. Именно поэтому мы сталкиваемся с ситуациями, когда «...реальные процессы информационного взаимодействия в организации протекают обособленно от так называемых «комплексных информационных систем» (систем - автоматизации).... Которые становятся «обузой» для организации, неким «компьютерным ритуалом менеджеров», мало связанным с их управленческой деятельностью ...»»

Здесь проявляется уже ранее обозначенная проблема смешения инструментов и назначения информационных технологий и средств автоматизации. Такая ситуация возможна только в одном случае, когда отсутствует научная теоретическая модель управления информационным пространством субъекта предпринимательства (организации). Таким образом, вторая предпосылка выражает потребность в создании теоретического базиса, модели информационной инфраструктуры субъекта предпринимательской деятельности. Модели, которая может рассматриваться как теоретическая и концептуальная основа развития современных систем автоматизации и информатизации процессов хозяйственной и управленской деятельности.

Предложенное видение предпосылок, генезиса концепции информационной инфраструктуры явно выражается как на практическом уровне (первая значительный рост объемов информации, информационный кризис, трансакционных расходов субъекта предпринимательской деятельности), так и на теоретическом

${ }^{1}$ Ярных Э.А. Информационная инфраструктура и статистический анализ рынка товаров и услуг: монография. М.: Финансы и статистика, 2004.

${ }^{2}$ Hanseth O., Ciborra C. U. and Braa K. The Control Devolution: ERP and the Side Effects of Globalization. The DATA BASE for Advances in Information Systems- Fall. 2001. Vol. 32. No. 4. 2002; Игнатьева Е.А. СRМ-системы в информационной инфраструктуре компании, корпоративные финансы. М.: 2007; Toвcmblx Л. E. Фирма, бизнес фирмы, моделирование бизнеса и управление: системные аспекты // Экономическая кибернетика: системный анализ в экономике и управлении: сб. науч. тр. Вып. № 10. СПб.: Изд-во СПбГУЭФ, 2004.

${ }^{3}$ Шумакова О. В. Формирование информационной инфраструктуры рынка аграрной продукции (на материалах Омской области): автореф. дис. ... канд. экон. наук: 08.00.05. Новосиб. гос. аграр. ун-т. Новосибирск, 2004 
(вторая -отсутствие теоретического базиса описания информационного пространства субъекта предпринимательства). Именно это дает основание предложить исследование концепции информационной инфраструктуры как востребованного теоретического знания.

Выдвинутое в 1999 г. F. Kimura и J. John положение о новом подходе к организации информационного пространства было развито в ряде работ в 2002-2009 гг. Теоретический интерес к концепции информационной инфраструктуры в современной науке можно продемонстрировать ростом числа российских (Б) и зарубежных (А) публикаций по вопросу (рис. 2.4). Большой вклад в развитие теоретических представлений, содержания концепции внесли российские и зарубежные ученые А. В. Андрейчиков, И. Е. Егорова, М. Полани, Д. В. Гуртов, В. А. Козлова, О. Ю. Полянская, П. Сенге, В. А. Сухомлин, О. Hanseth, J. Pironti, L. Payne, A. Toffler. Методы и алгоритмы развития информационного поля организации защищены в диссертационных исследованиях А. А. Афанакина, С. И. Головкиной, А. В. Бойченко, И. Н. Махониной, Е. Н. Ковалевой, В. Е. Козельского, А. В. Мартемьянова, Ю. В. Плетнева. Научные положения, изложенные в публикациях и диссертационных исследованиях, послужили основой для первичного осмысления и развития идей в данной работе.

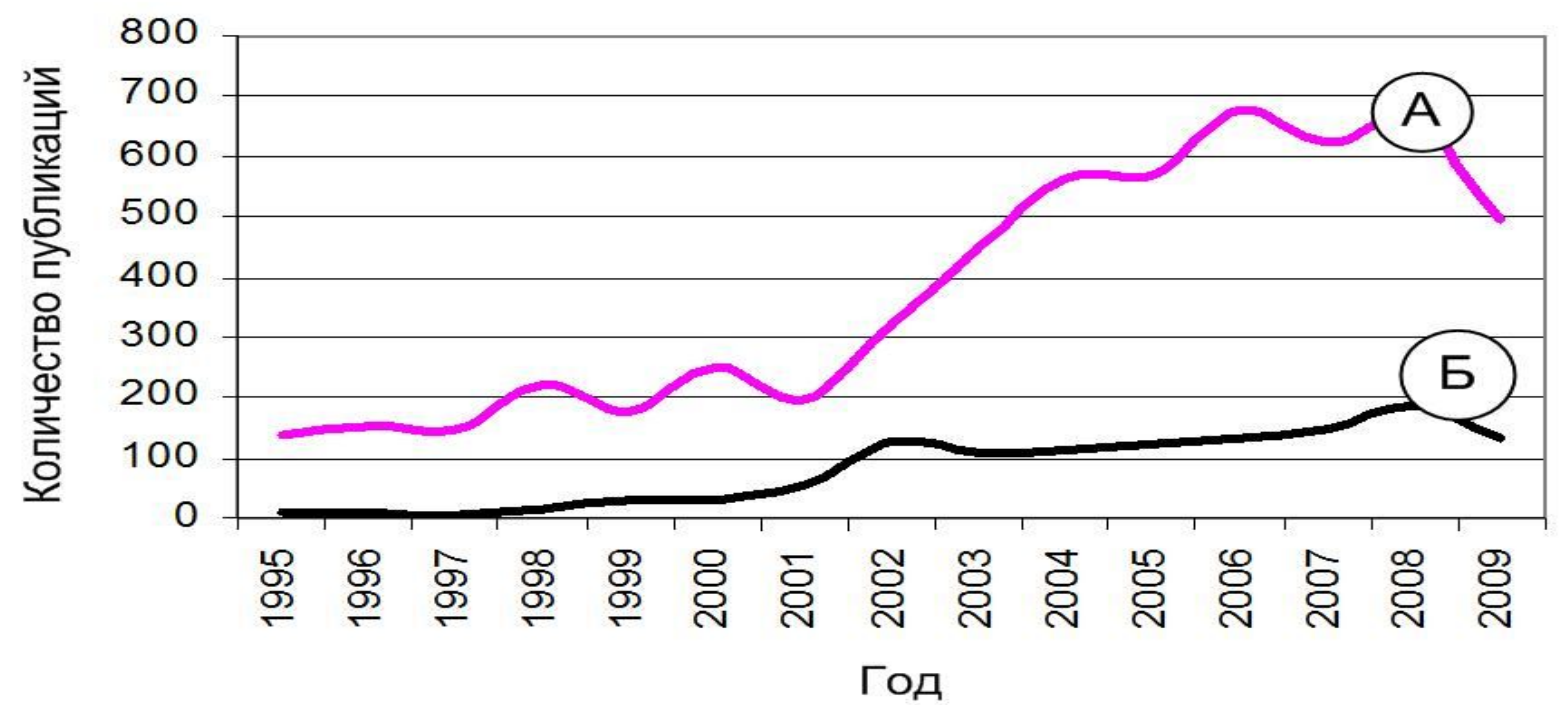

Рис. 2.4. Количество российских (Б) и зарубежных (А) публикаций по вопросам информационной инфраструктуры (по данным Библиографии Ассоциации Экономической Истории (Economic History Association) и Государственной публичной научно-технической библиотеки России (АН России, база данных ГРНТИ)

Научные подходы к управлению информационной инфраструктурой выражены в различных моделях и операционных инструментах, но, безусловно, едины как в постановке проблемы, так и в понимании парадигмы концепции. Проблема, рассмотренная как первая предпосылка, однозначно понимается как «...рост объема информационных потоков, трансакционных расходов при отсутствии адекватного инструментария их организации». А парадигма концепции основана на «...новом виде инфраструктуры, соответствующем современному развитию рыночных и 
производственных отношений - информационной» ${ }^{1}$. Инфраструктура, в общеэкономической трактовке понимается ${ }^{2}$ как комплекс взаимосвязанных обслуживающих структур, составляющих и/или обеспечивающих основу для решения проблемы (задачи).

В этом же контексте авторы понимают и информационную инфраструктуру, предлагающую новый вид обеспечивающего ресурса хозяйственной деятельности информацию. P. Weill, M. Broadbent в развитии положений M. Porat об информационной экономике видят современный (шестой) технологический уклад как «информационный», которому соответствует одноименный вид инфраструктуры ${ }^{3}$ :

технологический уклад 1, инфраструктура: оросительные каналы, проезжие дороги;

технологический уклад 2, инфраструктура: железные дороги, мировое судоходство;

технологический уклад 3, инфраструктура: электростанции, электрические распределительные сети, телефон, телеграф, радио;

технологический уклад 4, инфраструктура: скоростные автомобильные дороги, воздушное сообщение, аэропорты;

технологический уклад 5, инфраструктура: средства телекоммуникации, компьютерные сети, спутники;

технологический уклад 6, инфраструктура: информация.

Отсюда видно, что авторы понимают парадигму «концепции информационной инфраструктуры» как систему информационного обслуживания социальноэкономических систем субъектов предпринимательской деятельности, общества, национальной и интернациональной экономики. Это соответствует как общепринятому значению термина инфраструктура, так и предметной области ее отнесения - информационному пространству.

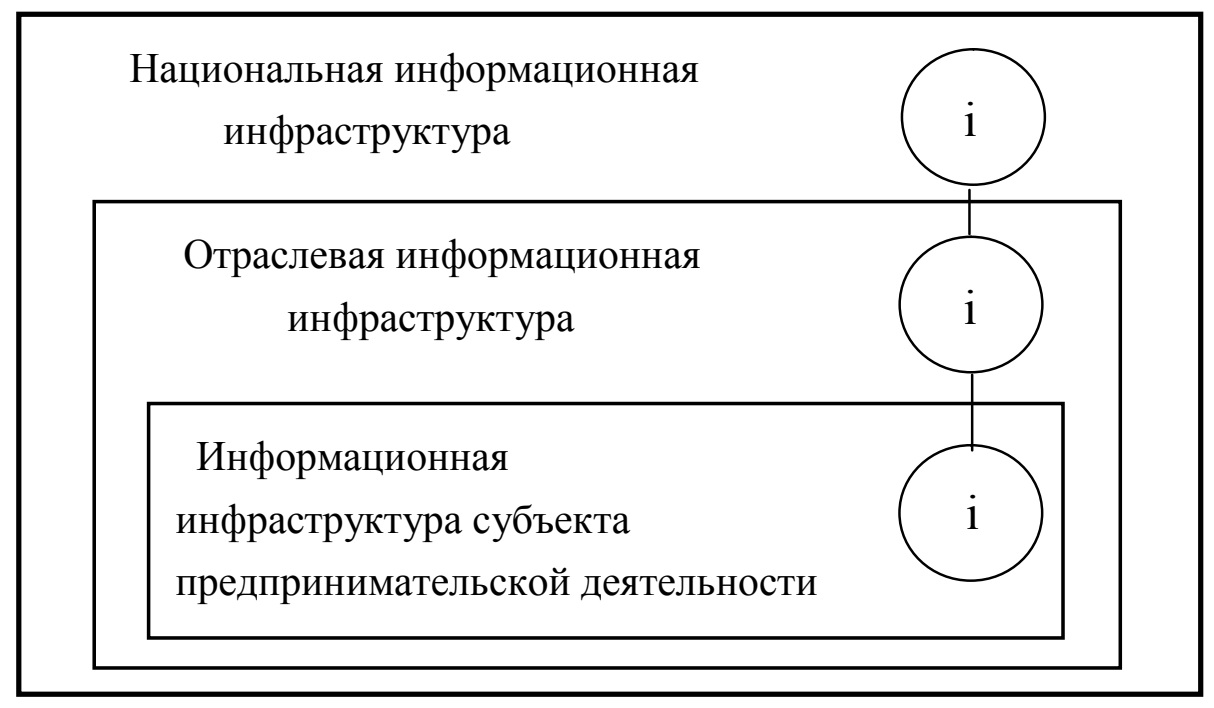

Рис. 2.5. Три уровня информационной инфраструктуры

Все научные исследования солидарно выдвигают три аспекта, три уровня исследования вопроса структурирования и управления информационной

\footnotetext{
${ }^{1}$ Cover T. M., Thomas J. A. Elements of information theory New York: Wiley, 1991.

${ }^{2}$ Голубева С. С. Инфраструктура рыночной экономики: учеб. пособие для студентов. М., 1998.

${ }^{3}$ Porat M. The Information Economy: Definition and Measurement. US Dept. of Commerce. Wash., 1976.
} 
инфраструктурой: национальный, отраслевой и субъекта предпринимательской деятельности (рис. 2.5). Конечно, все три уровня имеют безусловную внутреннюю взаимосвязь на уровне взаимного обмена информационными потоками, могут (и должны) представлять собой единую информационную систему. Но на каждом уровне можно выделить различных инициаторов (создателей, интеграторов) информационной инфраструктуры, что и определяет корректность выделения трех обозначенных уровней. В понятие национальной информационной инфраструктуры включают «...систему организационных структур, обеспечивающих функционирование и развитие информационного пространства страны и средств информационного взаимодействия» ${ }^{1}$. В США с 1995 г. реализуется программа развития национальной информационной инфраструктуры ${ }^{2}$, направленная на интеграцию информационного поля субъектов предпринимательской деятельности и государства. В Европейских странах парламенты рассматривают проекты создания информационной инфраструктуры национального экономического сообщества. В принципе, функция создания национальной информационной инфраструктуры принадлежит государству и должна быть выражена как правительственная инициатива. Понимается это и в России, президент Д. А. Медведев в выступлении (апрель, 2009 г.) на заседании «Совета по развитию информационного общества в Российской Федерации» обозначает данное направление как приоритетное ${ }^{3}$ : «...прогресс и модернизация невозможны без развития информационных технологий. Несмотря на то, что в последнее время информационно-коммуникационные технологии стали существенной статьей экспорта РФ, достигнув уровня в 1 млрд дол. (согласуется с данными Мирового Банка, табл. 2.1, с. 33), Россия до сих пор по ключевым показателям в этой сфере далека от развитых стран мира». Президент РФ напрямую ставит задачу развития национальной информационной инфраструктуры ${ }^{4}$ : «Россия в ближайшие два года должна преодолеть инфраструктурные и институциональные ограничения в сфере развития ИКТ и создать необходимые предпосылки интеграции в глобальное информационное общество».

Промежуточное значение между национальной и информационной инфраструктурой субъектов хозяйствования (организаций) занимает отраслевая. Отраслевая информационная инфраструктура направлена на координацию деятельности участников отрасли, создание общих информационных источников, реализация которых направлена на повышение эффективности и результативности деятельности всего отраслевого сообщества, качества и конкурентоспособности отраслевого продукта 5 . Инициатором на данном направлении, очевидно, являются отраслевые союзы и объединения, изначальная функция которых и определяется как информационная координация и представление интересов во взаимоотношениях с внешними контрагентами, государством. На данном направлении во многих отраслях

${ }^{1}$ Braa K., Rolland K. H. Horizontal Information Systems: Emergent Trends and Perspectives. In: Baskerville, R., Stage, J. and De Gross, J. I. (eds.). 2000. Organizational and Social Perspectives on Information Technology. Boston: Kluwer Academic Publishers, 2000.

${ }^{2}$ Branscomb L. M. and Kahin B. Standards Processes and Objectives for the National Information Infrastructure. In: Kahin. B and Abbate J. (eds.). Standards Policy for information infrastructure. Cambridge Mass.: MIT Press, 1995.

${ }^{3}$ Медведев Д. А. Выступление на заседании Совета по развитию информационного общества в Российской Федерации. М.: Агентство РИА, 2009.

${ }^{4}$ Медведев Д. А. Выступление на заседании Совета по развитию информационного общества в Российской Федерации.

5 Мартемьянов $A$. B. Повышение эффективности функционирования регионов на основе развития информационной инфраструктуры: автореф. дис. ... канд. экон. наук: 08.00.05. Орел, 2006. 
экономики предпринимаются значительные усилия по созданию единого информационного пространства. Особенно они выражены в тех секторах, где существует сложная схема взаимодействия субъектов предпринимательской деятельности, относящихся к различным видам деятельности: инвестиционностроительная, топливно-энергетическая, высокие технологии и другие. Стоит отметить особое значение отраслевой информационной инфраструктуры, которая в силу ее промежуточного положения (см. рис. 2.5) во многом определяет развитие как национального информационного поля, так и интегративных возможностей со стороны отдельных организаций.

Понятие информационной инфраструктуры применительно $к$ субъектам предпринимательской деятельности, собственно являющейся объектом исследования, возникло относительно недавно (О. Hanseth, 2004, J. Pironti, 2006) и стало результатом междисциплинарного подхода (теорий современного менеджмента, экономической кибернетики и информационных технологий) к исследованию информационных процессов социально-экономической сферы. Хотя термин имел употребление и в более раннем периоде, его согласованное понимание в рамках концепции возникло в последние 3-5 лет. Первично O. Hanseth ${ }^{1}$ определил информационную инфраструктуру субъекта предпринимательской деятельности как формализованную в базу распределенную, развивающуюся, открытую, распределенную по источникам информацию. Несколько позже J. Pironti развил представление, включив в определение не только информацию, но и связанных с ней субъектов и процессов: «совокупность людей, процессов, процедур, инструментов, устройств и технологий, поддерживающих создание, использование, передачу, накопление и уничтожение информации» ${ }^{2}$. Еще один аспект информационной инфраструктуры компании был раскрыт в работах E. Monteiro ${ }^{3}$. Он предложил понимать информационную инфраструктуру компании как инструмент снижения трансакционных расходов на поиск информации. Вопросам снижения трансакционных затрат в строительстве за счет оптимизации информационного изобретательства посвящена работа ${ }^{4}$ выполненная в рамках научной школы «Методологические проблемы эффективности региональных инвестиционностроительных комплексов как самоорганизующихся и самоуправляемых систем» под руководством заслуж. деят. науки А. Н. Асаула. Действительно, создание концентрированного в отношении субъекта управления в организации информационного потока формализованной и обработанной (вторичной) информации способно сократить время на информационную подготовку решений, повысить качество управления процессами и системами организации.

Под информационной инфраструктурой субъекта предпринимательства подразумевают систему, состоящую из потока информации (объекта) и информационных технологий (способа воздействия на объект), приводящие к снижению уровня информационных шумов, повышению содержания релевантной

${ }^{1}$ Hanseth O., Ciborra C. U. and Braa K. The Control Devolution: ERP and the Side Ef-fects of Globalization. The DATA BASE for Advances in Information Systems - Fall 2001. Vol. 32. No. 4. 2002.

${ }^{2}$ Pironti J. Key Elements of a Threat and Vulnerability Management Program -Information Systems Audit and Control Association Member Journal [May 2006], IGWE, 2006.

${ }^{3}$ Monteiro E. Chapter 5: Actor-Network Theory and Information Infrastructure. In: Ci-borra, C.U. et al. (eds.). From Control To Drift - The Dynamics of Corporate Information Infra-structures. Oxford: Oxford University Press, 2005.

4 Асаул A. H,, Иванов С. Н. Снижение трансакционных затрат в строительстве за счет оптимизации информационного пространства / под ред. А. Н. Асаула. СПб.: АНО ИПЭВ. 2008. 
информации в общем потоке (пертинентность), концентрировании информационных потоков на субъектах компании, непосредственно использующих информацию. Приведенные в табл. 2.4 определения вполне согласуются как содержательно, так и с точки зрения акцентов на ключевых элементах информационной инфраструктуры. Проявляемые различия в определениях отражают не столько различное видение парадигмы концепции, сколько различный подход к моделированию совокупности методов и технологий обработки информационных потоков субъекта предпринимательской деятельности.

Таблица 2.4

Определения информационной инфраструктуры организации

\begin{tabular}{|l|l|}
\hline \multicolumn{1}{|c|}{ Автор } & \multicolumn{1}{c|}{ Определение } \\
\hline Hanseth O. $^{1}$ & $\begin{array}{l}\text { Формализованная в базу распределенная, развивающаяся, открытая, } \\
\text { распределенная по источникам информация. }\end{array}$ \\
\hline Pironti J. $^{2}$ & $\begin{array}{l}\text { Совокупность людей, процессов, процедур, инструментов, устройств и } \\
\text { технологий, поддерживающих создание, использование, передачу, } \\
\text { накопление и уничтожение информации. }\end{array}$ \\
\hline Игнатьева Е.А. $^{3}$ & $\begin{array}{l}\text { Социо-техническая конструкция, включающая экономических агентов, } \\
\text { ресурсы и процессы, обеспечиваемые информационно- } \\
\text { коммуникационными технологиями, и простирающиеся за границы } \\
\text { бизнес-сети фирмы. }\end{array}$ \\
\hline $\begin{array}{l}\text { Афанакин А. А. } \\
{ }^{4}\end{array}$ & $\begin{array}{l}\text { Организация взаимодействия информационных потоков, при этом } \\
\text { несущественно какой носитель. }\end{array}$ \\
\hline $\begin{array}{l}\text { Комлев Н. Г. } \\
\text { Бойченко А.В., } \\
\text { Филинов Е.Н. }\end{array}$ & $\begin{array}{l}\text { Совокупность каналов связи и банков информации, информационных } \\
\text { технологий, правовой и финансово-экономической базы деятельности } \\
\text { информационного сообщества. }\end{array}$ \\
$\begin{array}{l}\text { Совокупность информационных ресурсов, предоставляемых их } \\
\text { владельцами для общего использования, и средств доступа к этим } \\
\text { ресурсам со стороны пользователей (потребителей) ресурсов с } \\
\text { помощью телекоммуникационной среды. }\end{array}$ \\
\hline $\begin{array}{l}\text { Словарь- } \\
\text { справочник по } \\
\text { современной } \\
\text { экономике }\end{array}$
\end{tabular}

${ }^{1}$ Hanseth, O. From systems and tools to networks and infrastructures - From design to cultivation. Towards a theory of ICT solutions and its design methodology implications, Oxford Press - 2004.

${ }^{2}$ Pironti, J. Key Elements of a Threat and Vulnerability Management Program - Information Systems Audit and Control Association Member Journal [May 2006], IGWE, 2006.

3 Игнатьева, Е.А. CRM-системы в информационной инфраструктуре компании, корпоративные финансы, М.: 2007.

4 Афанакин, А. А. Методы формирования инфраструктуры промышленного предприятия на основе информационных технологий: автореферат диссертации на соискание ученой степени канд. экон. наук: 08.00.05 / А. А. Афанакин. - СПб., 2002.

5 Комлев, Н. Г. Словарь новых иностранных слов (с переводом, этимологией и толкованием), Изд-во МГУ М. 1995.

6 Бойченко, А.В., Филинов, Е.Н. Нормативно-техническая база информационной инфраструктуры, Информационное общество, М.: 2005.

${ }^{7}$ Мишкевич, М. В., Василевская, Л. И., Ермаков В. Н., Плотницкий М. И. Словарьсправочник по современной экономике На пяти языках, Вышэйш. шк. Минск, 1996. 


\begin{tabular}{|l|l|}
\hline Автор & \multicolumn{1}{c|}{ Определение } \\
\hline & $\begin{array}{l}\text { банков данных и знаний, систем связи и обеспечивает доступ } \\
\text { потребителей к информационным ресурсам. }\end{array}$ \\
\hline
\end{tabular}

В описаниях и определениях информационной инфраструктуры субъекта предпринимательской деятельности один существенный недостаток, не позволивший до сегодняшнего дня воплотить данную концепцию в организационнотехнологическое решение. В определениях (и концепциях, соответствующих авторов) отсутствует описание иелевого фактора преобразования информационных потоков информационной инфраструктурой, согласованного с принципами и задачами существования субъекта предпринимательской деятельности организации. Разумеется, можно рассуждать о повышении пертинентности информационной системы и механизмах концентрации информационных потоков, но это скорее функции, внутренние механизмы преобразования данных информационной инфраструктурой, а не цель и задачи ее воплощения в организации. Между тем, анализ включенных в определение понятий (организация и инфраструктура) позволяет уточнить содержание и назначение способов воздействия на информацию, как на субъекта предпринимательской деятельности.

Итак, организация представляет собой общественный механизм, создание которого преследует коллективные цели, деятельность которого каким-то образом управляется, и который каким-то образом отделен от окружения ${ }^{1}$. Ключевым элементом можно выделить деятельность по управлению процессами организации, что в исследуемом определении, согласующемся $\mathrm{c}$ теорией современного менеджмента, означает целевую функцию информационной инфраструктуры участие в процессе формирования и оценки эффективности управленческих решений. С другой стороны, инфраструктура подразумевает систему обслуживания процессов. Синтезируя оба толкования, можно рассуждать об информационной инфраструктуре организации как системе информационного обеспечения (обслуживания) процесса принятия решений субъектами организации. Но информация в управленческих процессах, согласно современным положениям кибернетики ${ }^{2}$, является не обслуживающим элементом, а средством принятия и воплощения решений. Это позволяет рассуждать об информационной инфраструктуре организации как об элементе системы управления, а не ее обеспечения. Развитое определение информационной инфраструктуры организации может быть выражено как система информационного взаимодействия субъектов и объектов организации, направленная на формирование и оценку эффективности управленческих решений. Определив, что под управленческое решение подпадают как хозяйственные, производственные процессы, так и система администрирования, понятно, что информационная инфраструктура охватывает все аспекты, элементы и уровни деятельности организации. Действительно, описание информационной инфраструктуры организации как «вещи в себе» абсурдно, она может быть рассмотрена только применительно к субъекту управления; процессам управления в организации. Именно поэтому предложенное определение можно считать более корректным применительно к организации. Итак, сформированные теоретические представления

\footnotetext{
${ }^{1}$ Мильнер Б.3. Теория организации: учебник. 7-е изд. М.: Инфра-М, 2008.

${ }^{2}$ Сенге П. Пятая дисциплина: искусство и практика самообучающейся организации. М.: 3АО «Олимп-Бизнес», 1999.
} 
об информационной инфраструктуре позволили определить ее как в рамках исследуемого социально-экономического явления, так и в формате научной концепции. Выделенная парадигма исследования позволила рассмотреть место информационной инфраструктуры организации в национальном и отраслевом информационном пространстве. Развитое и уточненное определение информационной инфраструктуры организации создает основу для критериального анализа предлагаемых моделей организации информационного поля субъектов предпринимательской деятельности в последующем контексте настоящего исследования.

\section{2. ИССЛЕДОВАНИЕ МОДЕЛЕЙ ИНФОРМАЦИОННОГО ПОЛЯ СУБЪЕКТА ПРЕДПРИНИМАТЕЛЬСКОЙ ДЕЯТЕЛЬНОСТИ}

Рост эффективности реализуется через фактор качества основного ресурса системы управления - информации, выражаемый через ее пертинентность. Пертинентность определяется как содержание $(\%)$ полезной информации в информационном потоке - в динамике, в поле субъекта предпринимательской деятельности (компании) - в статичных наблюдениях. Исследуемая концепция подразумевает, что заданное качество управленческой информации может быть достигнуто организацией информационного поля в соответствии с моделями «информационной инфраструктуры». Модели предлагают подходы к организации взаимодействия объектов и субъектов компании реализующие:

- структурирование внутренних и внешних информационных потоков, обеспечивающее повышение пертинентности, отсечение паразитной (ложной, неактуальной, несодержательной) и дублирующейся информации, снижение шумов (помех) в процессе ее передачи;

- информационное обеспечение - организация информационного поля в окружении сотрудников компании, основанного на внутренней вторичной информации (т. е. обработанной и готовой к использованию в рамках технологического или управленческого процесса).

Такое понимание концепции информационной инфраструктуры субъекта предпринимательской деятельности отличается от существующих подходов. Его главным отличием, развивающим научную парадигму, является выделение цели функционирования информационной инфраструктуры - реализация контуров управления. Поведение, функционирование субъекта предпринимательской деятельности воспринимается как множество процессов принятия решений на всех уровнях. А инфраструктура не как система информационного обеспечения, а как элемент системь взаимодействия субъектов и объектов в проиессах управления компанией. Такой подход обусловливает соответствующие критерии адекватности, требования к синтезируемой модели информационной инфраструктуры субъекта предпринимательской деятельности. Впрочем, предлагаемые ниже критерии не являются чем-то принципиально новым, они выражают требования к информации со стороны системы менеджмента субъекта предпринимательской деятельности. В тех или иных формулировках, контекстах они встречаются в научной литературе по теории менеджмента или кибернетики ${ }^{1}$. Но в сводной форме и применительно к

\footnotetext{
${ }^{1}$ Абрамов Ю. Ф. Картина мира и информация. Иркутск: Изд-во Иркутск, ун-та, 1988; Говорин А. А.
} 
информационной инфраструктуре субъекта предпринимательской деятельности критерии ранее не формулировались.

Критерий 1. Ориентированность на акты управления и их последствия. С позиций кибернетики и теории менеджмента информация выступает как управленческий ресурс: основание для принятия решения и сведения об их последствиях. Информационная единица, не участвующая в актах управления, определяется «паразитной» - снижающей эффективность решений (увеличивая время принятия решений, соответственно и трансакционные расходы). Такой взгляд на пертинентность информации отличается от парадигмы «информационного обеспечения», в которой любая единица информации обладает «ценностью, если может быть привязана к предметной сфере деятельности субъекта предпринимательской деятельности или еe подразделений» ${ }^{1}$. Основанием формулировки такого критерия является вышеобозначенная роль информационной инфраструктуры - фильтрация потоков информации. Идеальной информационной единицей, обладающей 100\%-ной пер-тинентностью, можно считать сообщение, содержащее минимально достаточную с позиции получателя информацию для принятия решения. Например, продавец должен принять решение о назначении цены на товар в рыночных условиях. В условиях 100\%-ной пертинентности он должен получить два сообщения (достаточный уровень управленческой информированности): о ценовой политике (например, на товары группы «А» назначаются среднерыночные цены) и величину среднерыночной цены на текущую дату. В данной ситуации вся информация за пределами данных двух сообщений считается паразитной. В развитие ситуации продавец (как субъект управленческих решений) получает (запрашивает) информацию (сообщение) об объеме продаж группы «А», сообщение об ожидаемых норме прибыли и объеме продаж и на этом основании корректирует цену. Наблюдается классический кибернетический контур управления, содержащий минимально достаточную (перти-нентную) информацию. То есть, критерий выражает требование к информационной инфраструктуре как поставщику информационных ресурсов в рамках регламентированных, алгоритмизированных контуров управления субъекта предпринимательской деятельности и отрицает процесс получения, обработки и накопления «полезных сведений», не определенных как информационный ресурс. Критерий 2. Выраженность роли субъектов управления и их информационного взаимодействия в компании. Ориентированность на акты управления неотделима от субъектов управления, сотрудников компании, непосредственно формирующих управленческие решения. «Механистические» модели, отражающие линейное (иерархическое, формально структурированное) движение информационных потоков вынуждены рассматривать субъектов управления как «алгоритмизированный, рациональный элемент системы управления» ${ }^{2}$. Такой подход не приемлем в рамках современных взглядов на организацию, которая более адекватно описывается биологическими,

Инфраструктура современного предпринимательства: проблемы теории и практики. М.: $3 А О$ «Финстатинформ», 1999; Ковалева Е. Н., Перепечкина Е. Г. Организация и развитие информационной инфраструктуры в современных экономических условиях: монография. Астрахань: Астрах, ун-т, 2007; Никитенкова M. A. Государственное регулирование информационной инфраструктуры США (конец ХХ-начало ХХІ веков): автореф. дис. ... канд. экон. наук. 08.00.14. М., 2005; Рыночная инфраструктура: состав, функции, взаимодействие с предприятиями: матер, науч.-практ. конф. с междунар. участием / под ред. А. И. Матвеева. СПб.: СПбДНТП, 1992.

${ }^{1}$ Бойченко $A . B$. Функциональная стандартизация информационных систем и инфраструктур: автореф. дис. ... канд. техн. наук: 05.13.11. М., 2004.

${ }^{2}$ Кузьмин И. В., Кедрус В. А. Основы теории информации и кодирования. Киев: Вища школа, 1986. 
эволюционными моделями. Б. 3. Мильнер в авторитетной работе «Теория организации» предлагает именно такое видение: «Отдельных работников и рабочие группы можно сравнить с нервными клетками. Для того чтобы сформировать мозг, нервные клетки должны быть здоровыми и находиться в свободных связях друг с другом таким образом, чтобы постоянно посылать информацию и получать ее от других нервных клеток, получая питание и кислород от систем, которые они обслуживают и помогают координировать».

Б. 3. Мильнер выделяет субъекта управления и его информационную взаимосвязь с другими сотрудниками как важнейшую составляющую целостности субъекта предпринимательской деятельности, возможности реализации задач управления. В цитируемом фрагменте очень четко читается представление об информационной инфраструктуре как системе информационного обмена субъектов управления. Понимание управленческой информации не только в рамках формализованных сведений, но и в формате передаваемых от субъекта к субъекту опыта, интуиции, компетенций (знаний, при целостном понимании) является крайне важным в моделировании информационной инфраструктуры. Настоящий критерий определяет необходимость включения в модели субъектов управления и системы взаимного обмена информацией, знаниями, в том числе в неформализованной форме.

Критерий 3. Независимость от формализованности информации. Обозначенная (в критерии 2) роль субъектов управления (сотрудников компании) и системы их информационного взаимодействия определяет требование к учитываемым в моделировании типам информационных потоков. Учет взаимодействия субъектов подразумевает включение в модель неформализованных потоков информации - основы внутриорганизационного взаимодействия сотрудников. В исследованиях C. Shapiro и H. R. Varian ${ }^{1}$ доля неформализованных информационных потоков субъекта предпринимательской деятельности оценивается в 80-90\%. В том же исследовании утверждается, что «...менеджеры в принятии решений более склонны опираться на советы, экспертное мнение коллег, руководителей, чем на формальные исследования, отчеты и экономику проектов». Роль неформализованной информации в управлении организацией исследуется в менеджменте знаний - выделенном в самостоятельную эволюционную концепцию (п. 1.2). Менеджмент знаний определяет ценность персональных интуиции, компетенции, опыта сотрудника и исследует способы их тиражирования в субъекте предпринимательской деятельности. Модель информационного поля подразумевает имитацию взаимодействия субъектов, в которой информация обретает черты сообщения, транслируемого между субъектами. Поэтому знания (опыт, компетенция, интуиция) могут учитываться только в процессе их тиражирования, передачи в форме сообщения между субъектами управления.

${ }^{1}$ Shapiro C. and Varian H. R. Information Rules - A Strategic Guide to the Network Economy. Boston, Mass.: Harvard Business School Press, 1999. 


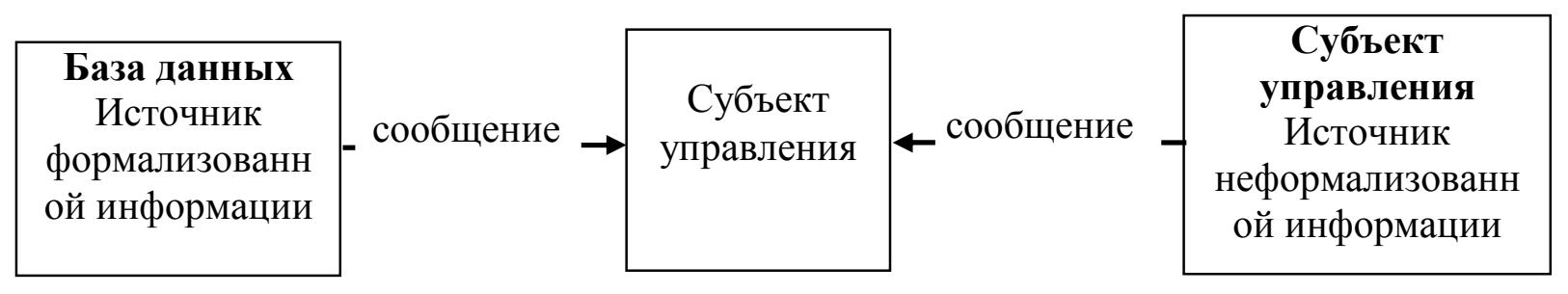

Рис. 2.6. Структура информационных оснований в принятии решений субъектом управления

Таким образом, модель информационного поля должна учитывать не только формализованные (например, накопленные в базе данных) потоки, но и неформализованный информационный обмен между субъектами (рис. 2.6). Учет в модели неформализованных потоков подразумевает установление границ и регламентов информационного взаимодействия субъектов, легализацию этих отношений, их формы, заложенную мотивацию к информационному обмену. Действительно, «...индивидууму, сотруднику организации отнюдь не свойственна добровольная передача собственного опыта и компетенций, помощь коллегам. Необходимы механизмы мотивации таких отношений, система поощрения к информационному взаимодействию, взаимной сопричастности в деятельности организации» ${ }^{1}$. Эти условия определяют требование первично закрепить в модели систему обмена неформализованными информационными потоками между субъектами управления.

Критерий 4. Динамичность и эволюционность. Динамичность и эволюционность свойственны любой современной организации, а соответственно, должны поддерживаться и учитываться в моделировании механизмов внутреннего взаимодействия. Динамичность и эволюционность проявляются в «...перманентном изменении организации - динамичной, открытой, самоорганизующейся системы» (Б. 3. Мильнер). Меняются задачи, функции, внутренняя структура, состав субъектов управления, содержание хозяйственной деятельности субъекта предпринимательской деятельности. Изменения носят как качественный, так и количественный характер, генезис которых определен непрерывным изменением внешней среды, необходимостью приспособления субъекта предпринимательской деятельности к новым факторам существования и развития. По Мильнеру «необходимость непрерывного изменения всех составляющих субъекта предпринимательской деятельности определяется ее «открытостью» как социально-экономической системы..., проявляется как поиск баланса с внешней средой». Понимая и принимая информацию как базовый структурный элемент управления организацией, необходимо предъявлять аналогичные требования к модели информационной инфраструктуры. Она не может носить характер изначально заданной статичной структуры взаимосвязей потоков информации. Динамичность и эволюционность субъекта предпринимательской деятельности должна поддерживаться либо самоорганизующимися механизмами информационного взаимодействия объектов и субъектов управления, либо универсальным принципом управления

Скузоватова О. Г. Формирование информационной инфраструктуры социальноэкономических управляющих подсистем: на примере агропром. подкомплекса. Самара: Изд-во Самар. гос. экон. акад, 2004. 
информационной инфраструктурой, необусловленным динамичностью субъекта предпринимательской деятельности. То есть в случае изменения внутренних факторов существования субъекта предпринимательской деятельности (состав сотрудников, структура подразделений, тип хозяйственных связей и т. п.) информационная инфраструктура должна сохранять свою целостность и функциональность.

Введенные четыре критерия являются основанием для анализа предлагаемых в научной литературе моделей управления информационной инфраструктурой. В настоящее время предложены и дискутируются три модели: «внешнего фильтра» О. Hanseth, «линейная» Е. Monteiro и «сбалансированная» J. Pironti. Рассмотрим данные модели с позиции соответствия выдвинутым критериям, предварительно раскрыв содержание предложенных механизмов построения информационной инфраструктуры субъекта предпринимательской деятельности.

Модель «внешнего фильтра», предложенная О. Hanseth ${ }^{1}$, построена на принципе «...отсечения внешнего потока первичной необработанной информации от менеджеров компании» (рис. 2.7). Субъекты управления используют либо внутреннюю информацию (IP, рис. 2.7) либо внешнюю формализованную отфильтрованную информацию (IF) - вторичную, поступающую в базу данных $(S)$ через фильтр, «информационную воронку» $(F)$. Фильтр обслуживается менеджером информации (M), содержание деятельности которого и ориентировано на формализацию и структурирование внешних информационных потоков (IFI). Основным достоинством модели «внешнего фильтра» считается разделение контуров движения внешней и внутренней информации, первичной и вторичной, формализованной и неформализованной.

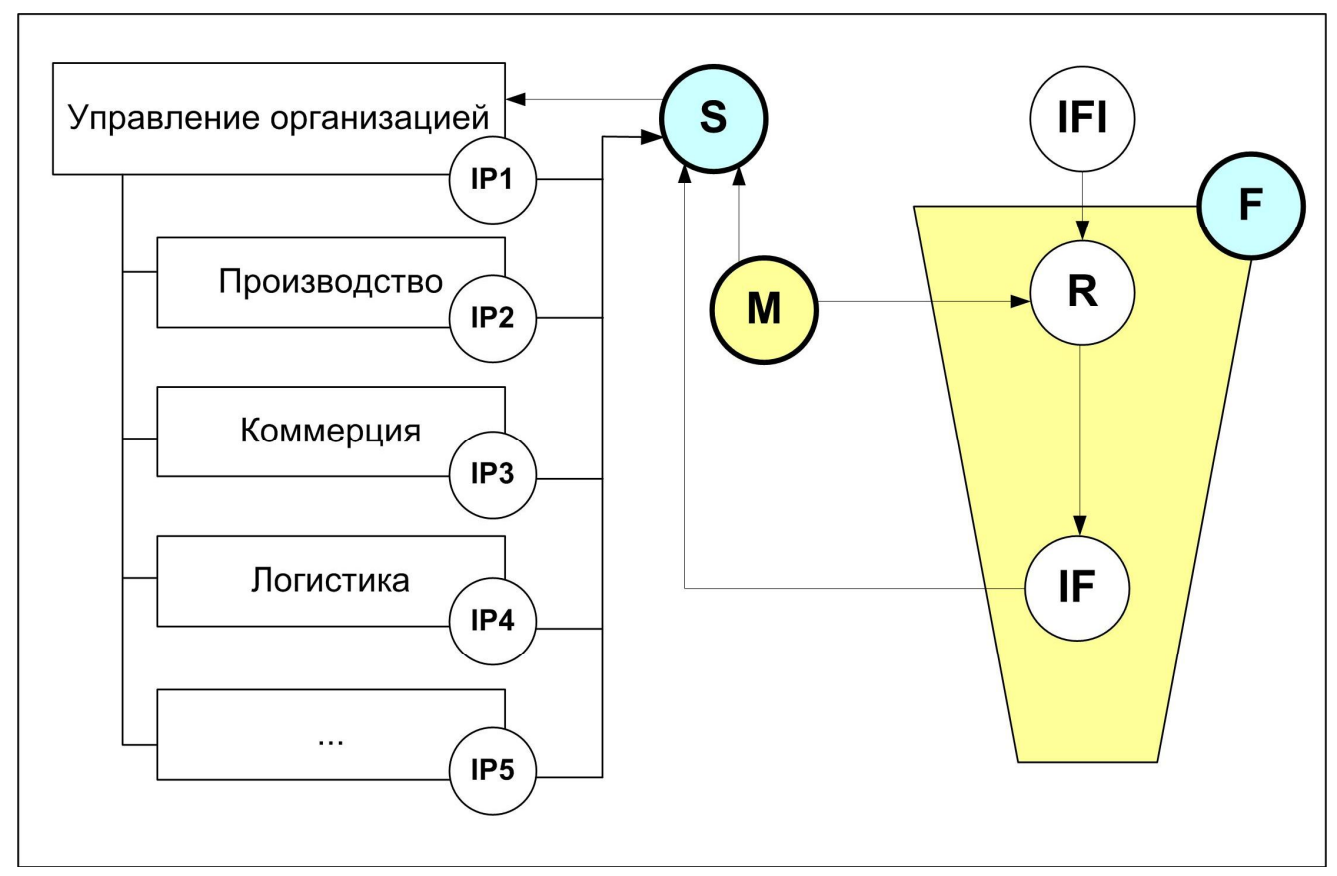

Рис. 2.7. Модель «внешнего фильтра» О. Hanseth информационной инфраструктуры (обозначения по табл. 2.5)

${ }^{1}$ Hanseth O., Monteiro E. and Hatling M. Developing Information Infrastructure: The Tension Between Standardization and Flexibility. Science, Technology \& Human Values. Vol. 21. No. 4. 2004. 
Обозначения в моделях информационной инфраструктуры субъекта предпринимательской деятельности

\begin{tabular}{|c|c|}
\hline Обозна & \multicolumn{1}{|c|}{ Содержание } \\
\hline$I F I$ & Внешняя первичная (необработанная) информация \\
\hline$I P$ & Внутренняя первичная (необработанная) информация \\
\hline$R$ & $\begin{array}{l}\text { Компьютеризированная система (вычислительный комплекс) первичной } \\
\text { обработки информации }\end{array}$ \\
\hline$M$ & $\begin{array}{l}\text { Менеджер информации (компетенция - информационные технологии и } \\
\text { вычислительные системы), субъект (сотрудник) компании }\end{array}$ \\
\hline$I F$ & Обработанная, формализованная и классифицированная информация \\
\hline$A$ & $\begin{array}{c}\text { Аналитик по предметной области информации (компетенция -предметная } \\
\text { сфера хозяйственной деятельности компании), субъект (сотрудник) организации }\end{array}$ \\
\hline$S$ & Накопитель информации, база данных \\
\hline$E$ & Интерфейс доступа к базе данных \\
\hline $\boldsymbol{u}$ & Пользователь информации, субъект (сотрудник) организации \\
\hline$F$ & $\begin{array}{c}\text { «нформационная воронка», комплекс методов фильтрации и обработки } \\
\text { информационных потоков }\end{array}$ \\
\hline
\end{tabular}

Модель, предложенная O. Hanseth, обладает высокой пертинентностью информационных потоков, поскольку информационная деятельность выделена в отдельную компетенцию соответствующего специалиста. Введенная иерархия информационных потоков по степени пертинентности информации (внутренняя вторичная - внутренняя первичная - внешняя вторичная) сокращает время поиска информации. Пользователь сначала обращается к внутренней вторичной информации, если не находит ответа - далее вниз по иерархии. Исторически модель О. Hanseth появилась первой (2002 г.) и главным ее достоинством считается понятие и модель «информационной воронки». Воронка, как фильтр, накладывается на информационное поле субъекта предпринимательской деятельности, создавая (вышеописанную) иерархию сведений. Данный элемент модели («информационная воронка») был признан удачным решением и в той или иной форме тиражировался в последующих моделях. Понятие информационной воронки было взято на вооружение разработчиками автоматизированных рабочих мест и программных комплексов. В частности, модель «внешнего фильтра» реализована в концепции программного комплекса ERP (англ. Enterprise Resource Planning System - Система планирования ресурсов компании), разрабатываемого компаниями 1C, Microsoft, CGI group, Infor Global Solutions, ПАРУС и другими.

Вместе с тем, в модели «внешнего фильтра» выделяют существенный недостаток, обнаруженный в процессе ее внедрения в действующие субъекты предпринимательской деятельности. Менеджер информации не может обладать достаточной компетенцией для обработки внешней информации в соответствии с потребностями субъектов управления (сотрудников) компании. Как минимум, его компетенция не может охватить все предметные сферы деятельности субъекта предпринимательской деятельности (финансы, коммерцию, логистику, производство и т. п.). С другой стороны, сотрудники компании, обладающие данной компетенцией, 
формально отсечены от потока внешней первичной информации. В итоге, имеем проблему качества и полноты внешней информации, потому что формализация выполняется специалистом другой области (менеджером информации). Именно этот недостаток отмечен E. Monteiro: «...достоинства модели «внешнего фильтра» трудно реализовать именно в силу того, что «воронка» слишком узкая, причем ее границы определяются не потребителем информации» ${ }^{1}$.

Monteiro Е. развил модель «внешнего фильтра», предложив решение, названное им «линейным» (рис. 2.8). Он предложил отдать функцию поиска первичной внешней информации (IFI) субъектам управления, рассматривая данное решение как устранение недостатка модели Hanseth. Более того, помимо менеджера информации он предлагает ввести в систему обслуживания «информационной воронки» аналитика по предметной области информации с компетенцией в предметной сфере хозяйственной деятельности компании ( $A$, рис. 2.8$)$. Аналитик, выражая потребности и запросы субъектов управления, структурирует информационные единицы в базу данных по областям принятия решений субъектами субъекта предпринимательской деятельности. Таким образом, воронка $(F)$ реализуется двухэтапной схемой. Внешняя и внутренняя первичная информация поступает от субъектов управления компании к фильтру - воронке, где преобразуется во вторичную в два этапа. Первым этапом ее фильтрует менеджер информации (M, см. рис. 2.8), используя методы информационных технологий, отделяя дублирующуюся, шумовую и паразитную. Вторым этапом аналитик (А) производит предметное фильтрование, сортировку и классификацию вторичной формализованной информации в базу данных

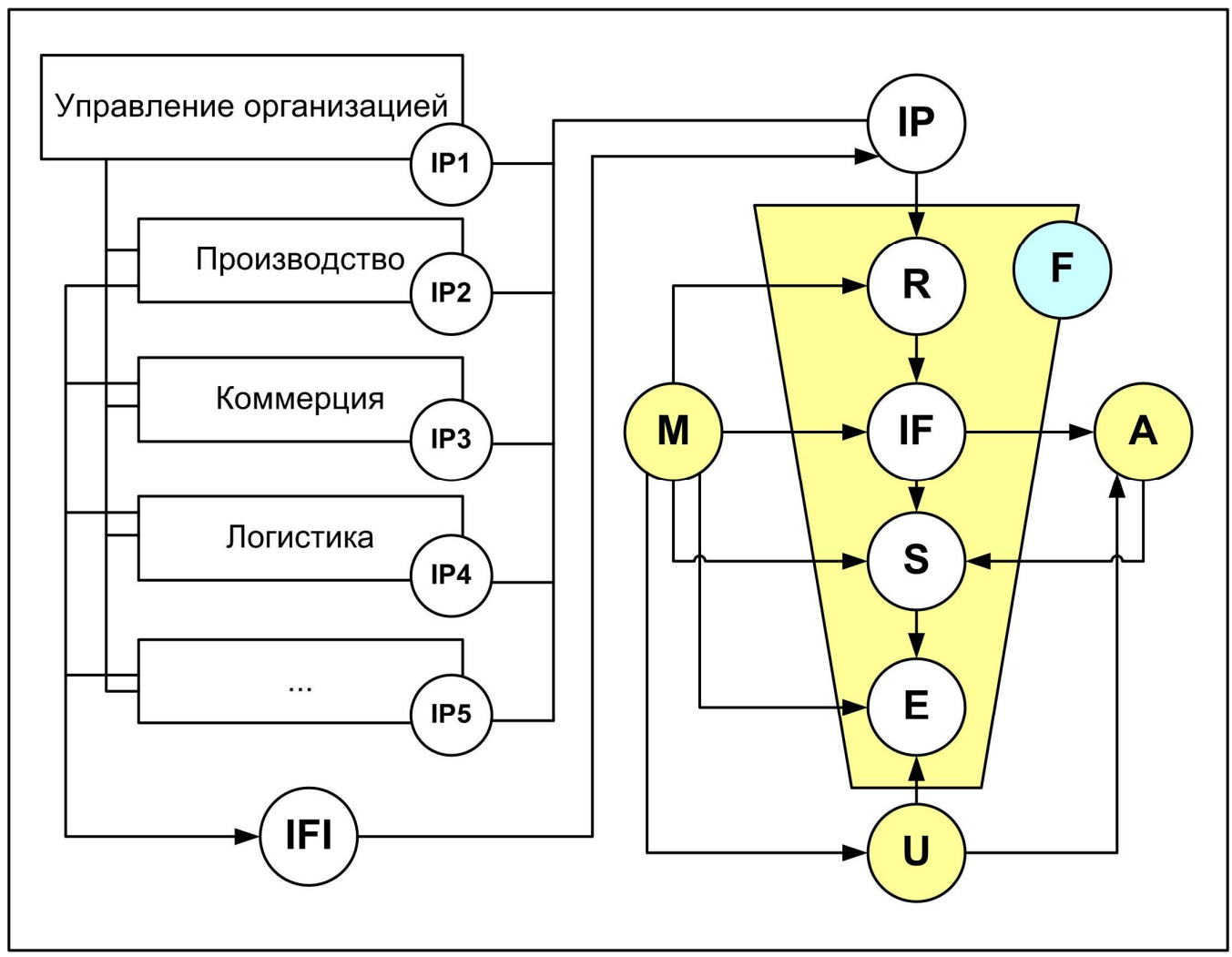

Рис. 2.8. Линейная модель информационной инфраструктуры E. Monteiro (обозначения по табл. 2.5)

${ }^{1}$ Monteiro E. Scaling Information Infrastructure: The Case of Next-Generation IP in the Internet. The Information Society. Vol. 14, 2007. 
. По существу, аналитик управляет базой данных компании во всех предметных областях деятельности (финансы, производство, логистика и т. п.).

Достоинствами линейной модели можно считать сохранение предложенных О. Hanseth методов разделения потоков и структурирования первичной и вторичной информации субъекта предпринимательской деятельности, развитые механизмы реализации информационной воронки. Воронка не только повышает пертинентность информации, но и сохраняет предметную целостность и ориентированность информационного содержания (за счет аналитика). Линейная модель является логическим развитием модели «внешнего фильтра» с точки зрения совершенствования механизмов фильтрации и форматирования первичных информационных потоков. Линейная модель часто берется за основу при проектировании предметных баз данных, выступает как логическая основа автоматизации «систем поддержки решений», DSS (англ. Decision Support System) «компьютерная автоматизированная система, целью которой является помощь людям, принимающим решение в сложных условиях для полного и объективного анализа предметной деятельности» ${ }^{1}$. Действительно, блок структурирования информации, реализуемый предметным аналитиком, позволяет подготовить информацию практически в минимально достаточном уровне для принятия решений, то есть с высокой пертинентностью.

К недостаткам, явно проявляющимся в реализации на практике линейной модели, относят высокую стоимость вторичной формализованной информации. Усилия аналитиков, затрачиваемые на предметное форматирование информации, часто не пропорциональны как характеру используемой информации, так и назначению ее использования. Аналитик не обладает (и не может обладать) полномочиями по оценке «ценности» информации в управленческом процессе. Он с равным усилиями обрабатывает как информацию по стратегическим показателям управленческого учета субъекта предпринимательской деятельности, так и по коммерческим предложениям на канцелярские товары для отдела закупок. Его усилия, обладая результативностью, редко эффективны. Более того, часть обработанной информации может не использоваться субъектами управления в дальнейшем. Посмотрим на примере компании ООО «Леноблзем» (строительство, девелопмент), внедрившей линейную модель, относительную эффективность ее реализации (табл. 2.6). «Леноблзем» использует автоматизированный документооборот класса DSS, поэтому учет информационных единиц был реализован через сетевой сервер субъекта предпринимательской деятельности. Расчеты затрат на организацию информационной воронки берутся по документам управленческого учета субъекта предпринимательской деятельности. Сущность демонстрируемого примера сводится к сравнению средней стоимости единицы востребованной вторичной информации (полученной в результате прохождения информационной воронки) с нижней границей стоимости решений (оценка финансового оборота в рамках единичного решения субъекта).

Таблица 2.6

Оценка эффективности использования линейной модели организации информационной инфраструктуры субъекта предпринимательской деятельности 000 «Леноблзем», 2007 г.

\footnotetext{
${ }^{1}$ Maxwell's Demon: Entropy, Information, Computing, H. S. Leff and A. F. Rex, Editors, Princeton University Press, Princeton, 1990.
} 


\begin{tabular}{|c|c|c|}
\hline Показатель & Обозначение & Значение \\
\hline $\begin{array}{l}\text { Количество файлов, поступающих на } \\
\text { информационную воронку }\end{array}$ & $I F I$ & 124872 \\
\hline $\begin{array}{l}\text { Затраты на первичную обработку методами инфор- } \\
\text { мационных технологий (менеджеры информации), дол. }\end{array}$ & $C P$ & 25800 \\
\hline $\begin{array}{l}\text { Затраты на вторичную предметную обработку } \\
\text { (аналитик). дол. }\end{array}$ & $C S$ & 49890 \\
\hline $\begin{array}{l}\text { Эксплуатационные затраты системы автоматизации, } \\
\text { дол. }\end{array}$ & $C A$ & 7600 \\
\hline $\begin{array}{l}\text { Итоговые годовые затраты создание информационного } \\
\text { поля, дол. }\end{array}$ & $C=C A+C S+C P$ & 83290 \\
\hline $\begin{array}{l}\text { Количество файлов, обработанных и заведенных в базу } \\
\text { данных, ед. }\end{array}$ & $I F$ & 4238 \\
\hline $\begin{array}{l}\text { Эффективность информационной воронки (по } \\
\text { фильтрации), \% }\end{array}$ & $E F=1-(I F / I F I)$ & 97 \\
\hline $\begin{array}{l}\text { Средняя стоимость единицы пертинентной информации, } \\
\text { дол. }\end{array}$ & $C E=C / I F$ & 19,65 \\
\hline $\begin{array}{l}\text { Количество файлов, использованных субъектами } \\
\text { управления (запрошенных из базы данных), ед. }\end{array}$ & $N$ & 456 \\
\hline $\begin{array}{l}\text { Востребованность информационного поля, } \\
\%\end{array}$ & $E N=N / I F$ & 11 \\
\hline $\begin{array}{l}\text { Средняя стоимость востребованной единицы вторичной } \\
\text { информации, дол. }\end{array}$ & $C E S=C / N$ & 182,7 \\
\hline $\begin{array}{l}\text { Нижняя граница стоимости решений (минимальная } \\
\text { сумма платежного поручения), дол. }\end{array}$ & $M L$ & 112 \\
\hline
\end{tabular}

Итак, по данным табл. 2.6 можно видеть, что с точки зрения задач получения пертинентной информации линейная модель информационной инфраструктуры себя оправдывает - эффективность фильтрации 97 \%. Но вызывает сомнение экономическая эффективность реализации модели в целом: только 11 \% вторичной формализованной информации востребовано в процессах принятия решений субъектами ООО «Леноблзем».

Опрос сотрудников компании показал, что остальные 89 \% информации они получают в личных контактах внутри самой компании, что подтверждает выводы ${ }^{1}$. С. Shapiro и H. R. Varian о роли неформализованной информации в подготовке решений. Именно такая низкая востребованность вторичной информации из базы данных (11 \%) определяет относительно высокую стоимость (182,7 дол. USA за единицу) внутренней информации. Относительно высокой ее можно считать при сопоставлении с нижней границей стоимости решений (112 дол. USA за единицу), то есть оборота субъекта предпринимательской деятельности, в отношении которого решение принимается. Заметим, что в описанную переменную (средняя стоимость востребованной единицы вторичной информации) вошла только себестоимость обработки информации и не включены значения стоимости получения информация (затраты сотрудников на получение первичной информации, ее покупка, затраты на экспертов и консультантов). Примечательны также полученные в опросе сотрудников сведения о том, что по серьезным сделкам они вообще не используют внутреннюю вторичную информацию, а только устную - полученную в личном контакте.

Можно видеть справедливость критики линейной модели, основанной на

\footnotetext{
${ }^{1}$ Shapiro C. and Varian H. R. Указ. соч.
} 
низкой востребованности вторичной информации (в силу отдаленности от субъекта управления) и относительно высокой стоимости субъекта предпринимательской деятельности информационной воронки. Данные недостатки линейной модели были взяты за отправную точку J. Pironti при синтезе модели, которую он назвал сбалансированной (рис. 2.9). J. Pironti предложил отказаться от субъектов - менеджера информации и аналитика, поступиться пертинентностью информации в пользу экономической эффективности информационной воронки.

Он утверждает, что «...современные возможности вычислительной техники достаточны для формального структурирования информации методами прагматического анализа» ${ }^{1}$. Сбалансированная модель по аналогии с линейной источником первичной информации определяет субъектов управления компанией. Но информационная воронка носит характер формального рубрикатора, основывается на простейших вычислительных сетевых решениях по структурированию информации. В качестве рубрикатора выступает система сбалансированных показателей субъекта предпринимательской деятельности (KPI), которая выражает стратегические и оперативные цели субъекта предпринимательской деятельности, области принятия решений. В теории менеджмента KPI (key performance indicator, или «система ключевых показателей) понимают как систему показателей, по которым оценивается результативность и эффективность субъекта предпринимательской деятельности и отдельных ее подразделений. Таким образом, информация, которая может быть отнесена к одному из заданных показателей деятельности субъекта предпринимательской деятельности, валидна и включается в базу данных. Если информационная единица не совпадает по смыслу ни с одним из показателей, то она принимается паразитной и уничтожается. Фильтр KPI реализуется методами и программными комплексами прагматического и семантического анализа ${ }^{2}$, которые оценивают наиболее часто используемые в контексте информационной единицы термины (рис. 2.10) и словосочетания и на основе их заносят единицу в ту или иную ветвь классификатора.

Итак, чего же добился J. Pironti в сбалансированной модели, что говорит о еe достоинствах. Во-первых, предложенные им механизмы снижают экономическую нагрузку на организацию, ее затраты на обработку информации. Во-вторых, он увеличил роль субъектов принятия решений в информационном поле, «приблизил» их как к первичным, так и ко вторичным источникам информации, то есть снял барьер между информационной воронкой и пользователями информации, увеличил полноту информационного поля. И в третьих, самое главное - он предложил реальный механизм выделения управленческой информации, то есть подчинил информационную инфраструктуру управленческим задачам субъекта предпринимательской деятельности. Предложенная им система сбалансированных показателей является тем самым механизмом, на основе которого можно реализовать требуемое качество управленческой информации, ее пертинентность. Если принять саму идею системы сбалансированных показателей ${ }^{3}$ как механизм выделения управленческих целей, критериев направленности оперативных управленческих решений, то сбалансированная модель предстает как удачное решение задачи

\footnotetext{
${ }^{1}$ Pironti J. Key Elements of a Threat and Vulnerability Management Program -Information Systems Audit...

${ }^{2}$ Павловский Ю. Н. Имитационные модели и системы. М.: ВЦ РАН, 2000.

${ }^{3}$ Ольве Нильс-Горан, Ро Жан. Сбалансированная система показателей: практич. руководство по использованию. М.: Диалектика-Вильяме, 2003.
} 
выделения информационной инфраструктуры субъекта предпринимательской деятельности, построенной в рамках развития системы менеджмента.

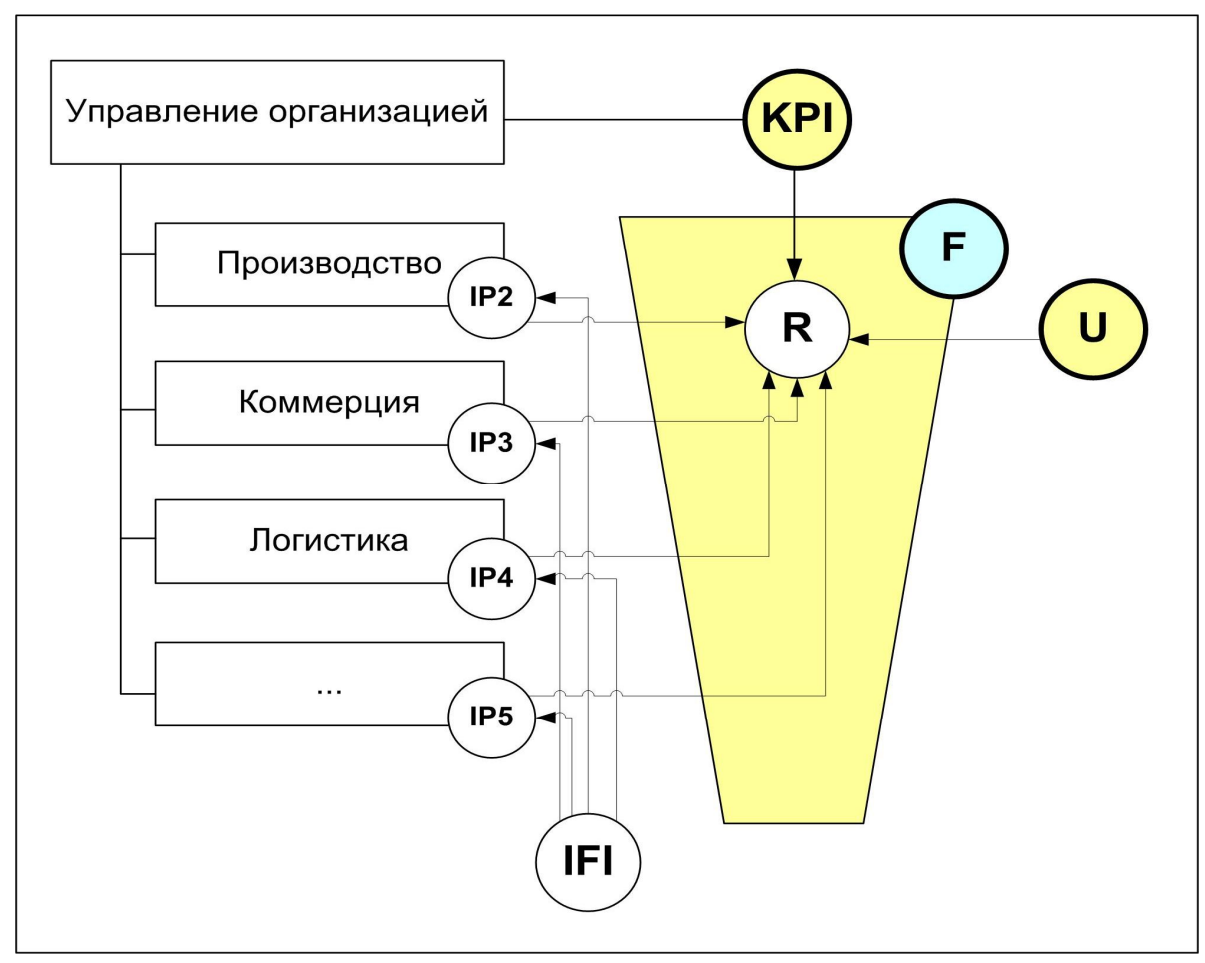

Рис. 2.9. Сбалансированная модель J. Pironti информационной инфраструктуры (обозначения по табл. 2.5)

Явные достоинства сбалансированной модели содержат и ее недостатки, в числе которых выделяют снижение пертинентности информации, возникающее вследствие переноса информационной деятельности на субъектов управления, снижения числа механизмов вторичной обработки информационных потоков. Повышение информационной емкости и содержательности информационного поля ведет к снижению пертинентности. Е. Monteiro, признавая вышеперечисленные достоинства сбалансированной модели информационной инфраструктуры, тем не менее категоричен в отношении оценки эффективности фильтра: «...сбалансированная модель настолько снижает роль информационной воронки, что я бы указал на ее отсутствие в модели. Скорее стоит рассматривать модель как сетевую, распределенную в отношении менеджеров, которые согласно представленных механизмов и выполняют роль узловых фильтров» ${ }^{1}$. Указанные недостатки не мешают внедрению сбалансированной модели - на ее основе развивается направление автоматизации, именуемое «системой управления на основе бизнес процессов» ${ }^{21}$.

Представленные три модели управления информационной инфраструктурой субъекта предпринимательской деятельности вполне понятны как по своему подходу к организации информационного пространства, так и по выраженным достоинствам и

${ }^{1}$ Monteiro E. Chapter 5: Actor-Network Theory and Information Infrastructure. In: Ciborra, C.U. et al. (eds.). From Control To Drift - The Dynamics of Corporate Information Infrastructures. Oxford: Oxford University Press, 2005.

${ }^{2}$ Little I. D. C. Models and Managers: The Concept of a Decision Calculus // Management Science, 1970. V. 16. N 8 . 
недостаткам. Но модели должны сначала удовлетворять предложенному пониманию информационной инфраструктуры, то есть соответствовать выдвинутым критериям. Модель, в наибольшей степени им соответствующая, может рассматриваться как прототип синтезируемой в работе системы управления информационным полем в рамках выдвинутой парадигмы - информационная инфраструктура как ресурс системы менеджмента субъекта предпринимательской деятельности.

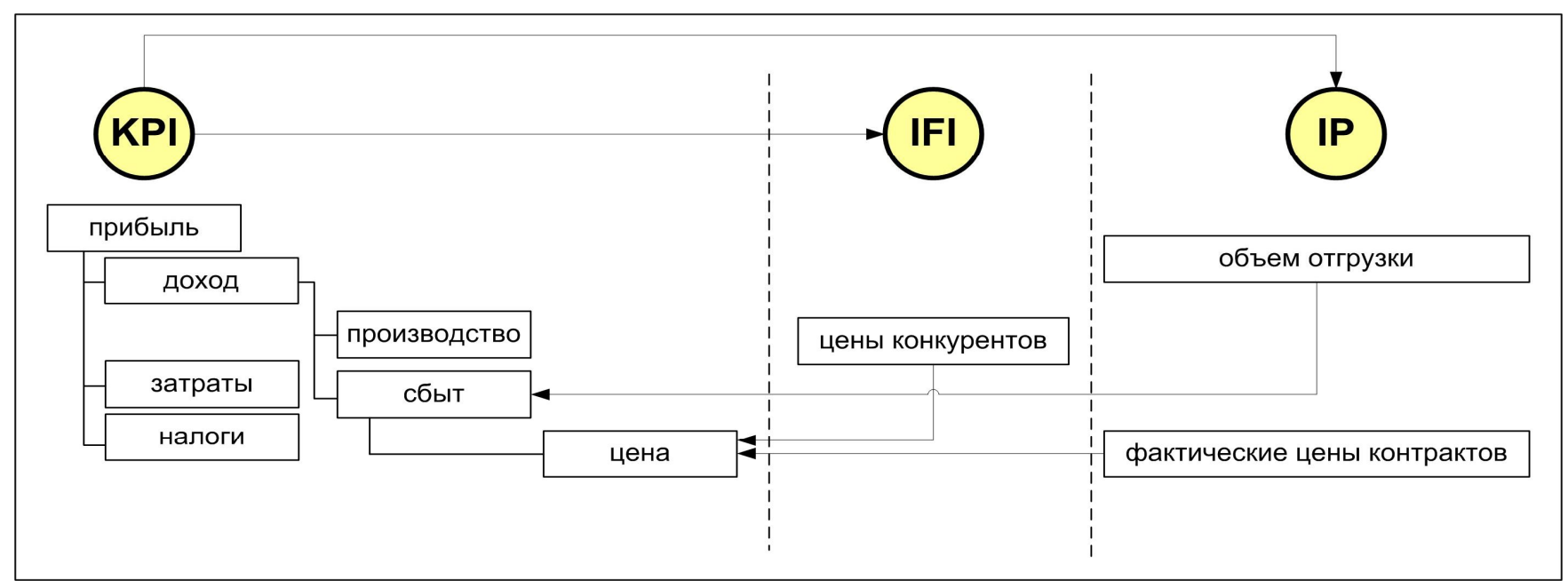

Рис. 2.10. Фрагмент структуры KРI фильтра сбалансированной модели (обозначения по табл. 2.5)

Критерий 1. Ориентированность на акты управления и их последствия. Очевидно, что в моделях «внешнего фильтра» и «линейной» функция управления не выражена. Реализуя идею информационной воронки, авторы сосредоточились на описании механизмов достижения идеальной пертинентности информации. Но при этом целевая функция качества информации выпадает из механизмов обработки сведений. Поток информации, его пертинентность - практически самоцель синтеза информационного поля субъекта предпринимательской деятельности. Именно поэтому в данных моделях трудно выстроить вектор усилий аналитиков и менеджеров информации, что, как следствие, ведет к экономической неэффективности (см. табл. 2.6) системы обработки информации. Сбалансированная модель отвечает критерию ориентированности на управление организацией, именно из-за заложенного принципа структурирования информационных потоков управленческих показателей всех уровней. Сама идея сбалансированных показателей может быть рассмотрена как механизм структурирования, классификации единиц информационного поля, их соответствия областям принятия решений.

Критерий 2. Выраженность роли субъектов управления и их информационного взаимодействия в компании. Практически все модели понимают субъекта управления как поставщика первичной информации и пользователя с нечеткими целями и назначением информационных единиц. Они видят его как «черный ящик», действия которого необходимо обслуживать: структурировать поступающую от него неупорядоченную информацию, возвращать ему информацию, упорядоченную и организованную по неопределенному принципу или умозрению менеджера информации - аналитика. В моделях наблюдается точное выражение определений информационной инфраструктуры, которое дается авторами - 
информачионное обеспечение, прочессы обработки $u$ структурирования информационных потоков. Контексту роли субъекта, носителя формализованной и неформализованной информации, инициатора управленских актов частично соответствует сбалансированная модель. Частичность выражена в допускаемой возможности сопоставления ключевых показателей с соответствующими сферами предметной деятельности. Но явного выражения фактора субъекта управления сбалансированная модель не предлагает, механизмы горизонтального взаимодействия не описываются.

Критерий 3. Независимость от формализованности информации. Все модели построены как «компьютерные», алгоритмизированные, вычислительные: учитывают только формализованные документированные потоки информации, модели подстроены и подчинены современным возможностям инфокоммуникационных технологий. Предложенные модели информационной инфраструктуры исходят из потенциала автоматизации процессов, что ведет к неоправданному упрощению и необоснованному редуцированию моделей менеджмента конкретной компаний. С другой стороны, понятно, что субъект принимает решение, опираясь в большей степени на неформализованные сведения, полученные в результате собственной (или сторонней) практической деятельности. В процессе формирования решения происходит обмен опытом и сведениями между субъектами, который (опыт) не имеет формализованной основы (мнения, убеждения, интуиция). Трансфер, передача знаний, является важнейшим элементом информационной инфраструктуры субъекта предпринимательской деятельности ${ }^{1}$, исключение которого является недопустимым упрощением модели менеджмента субъекта предпринимательской деятельности. Именно с позиций этого критерия не удовлетворительна ни одна из предложенных моделей.

Критерий 4. Динамичность и эволюционность. Все модели, с одной стороны, допускают развитие механизмов обработки информации в процессе развития субъекта предпринимательской деятельности. Как минимум, не видно препятствий для реализации динамических изменений. Менеджер информации и аналитик в моделях, построенных на обслуживании информационной воронки, могут получать критерии отбора информации от пользователя. А в сбалансированной модели само изменение структуры ключевых показателей ведет к изменению механизмов фильтрации, состава и контекста отбора. С другой стороны, авторы моделей в явном виде не предлагают подходов к динамическому изменению системы информационной инфраструктуры. Подходов, которые бы демонстрировали гибкость информационной инфраструктуры, возможность ее автоматической подстройки под развитие системы управления организацией, состава субъектов управления, да и собственно управленских задач. По большому счету, все предпринимательские модели хозяйствования (см. п. 3.2) должны учитывать динамический характер системы менеджмента, а синтез информационной инфраструктуры, основного управленческого ресурса, должен моделироваться как самоорганизующаяся система.

Итак, критериальное соответствие моделей может быть представлено в виде матрицы (табл. 2.7), в которой соответствие выражается параметрами «да», «нет», «частично». Из сводной матрицы видно, что в полном виде ни одна из представленных моделей не может быть использована для описания информационной инфраструктуры субъекта предпринимательской деятельности в

\footnotetext{
${ }^{1}$ Модернизация экономики на основе технологических инноваций / А. Н. Асаул [и др.]. СПб:
} АНО ИПЭВ, 2008. 
рамках сформулированной управленческой парадигмы. Наиболее близкой прототипной можно принять сбалансированную модель J. Pi-ronti, хорошо соответствующую критерию ориентированности на управленческие акты.

Вместе с тем, сбалансированная модель требует совершенствования путем:

Критериальное соответствие моделей

\begin{tabular}{|l|c|c|c|}
\hline \multirow{2}{*}{ Критерий } & \multicolumn{2}{|l|}{ Модели } \\
\cline { 2 - 4 } & $\begin{array}{c}\text { «внешнего } \\
\text { фильтра» } \\
\text { Напseth }\end{array}$ & $\begin{array}{c}\text { «линейная» } \\
\text { Е. Monteiro }\end{array}$ & $\begin{array}{c}\text { «сбалансиро- } \\
\text { ванная» J. } \\
\text { Pironti }\end{array}$ \\
\hline $\begin{array}{l}\text { Критерий 1. Ориентированность на } \\
\text { акты управления и их последствия }\end{array}$ & Нет & Нет & Да \\
\hline $\begin{array}{l}\text { Критерий 2. Выраженность роли } \\
\text { субъектов управления и их } \\
\text { информационного взаимодействия }\end{array}$ & Нет & Нет & Частично \\
\hline $\begin{array}{l}\text { Критерий 3. Независимость от } \\
\text { формализованности информации }\end{array}$ & Нет & Нет & Нет \\
\hline $\begin{array}{l}\text { Критерий 4. Динамичность и эволю- } \\
\text { ционность }\end{array}$ & Частично & Частично & Частично \\
\hline
\end{tabular}

а) включения субъектов управления и системы их информационного взаимодействия в описание информационной инфраструктуры субъекта предпринимательской деятельности;

б) развития представлений о движении неформализованных сведений в информационном поле субъекта предпринимательской деятельности, обнаружении и регламентации данных типов информационных потоков;

в) декларации механизмов самоорганизации, направленных на повышение адаптивности информационной инфраструктуры к эволюционному развитию субъекта предпринимательской деятельности.

Итак, проведен критериальный анализ современных научных моделей управления информационной инфраструктурой субъекта предпринимательской деятельности, выделен прототип и направления его совершенствования.

\section{3. ПРИНЦИПЫ ФОРМИРОВАНИЯ ИНФОРМАЦИОННОЙ ИНФРАСТРУКТУРЫ СУБЪЕКТА ПРЕДПРИНИМАТЕЛЬСТВА}

Теоретическими предпосылками актуальности моделирования информационной инфраструктуры субъекта предпринимательства (компании) следует определить ранее обоснованные положения:

1. Введение понятия информационной инфраструктуры как объективного явления - совокупности субъектов и объектов компании, находящихся в информационной взаимосвязи; концепции структурирования, управления информационным пространством субъекта предпринимательства.

2. Положение о концепции информационной инфраструктуры как наиболее 
перспективного теоретического подхода к синтезу модели информационных потоков хозяйственной и управляющей деятельности субъекта предпринимательства.

3. Развитие парадигмы (и определение) информационной инфраструктуры, обоснованной и принятой в настоящем исследовании: система информационного взаимодействия субъектов и объектов компании, направленная на формирование и оценку эффективности управленческих решений.

4. Введенные критерии адекватности предлагаемых моделей информационной инфраструктуры содержанию парадигмы.

5. Модель, выбранная как научный прототип, для развития - сбалансированная модель J. Pironti.

Формат представления концепций организации информационной инфраструктуры (п. 2.2) «внешнего фильтра», «линейной» и прототипной «сбалансированной» концепции не соответствует как общей научной методологии моделирования, визуализации моделей, так и более узким требованиям теории информационных синтеза моделей социально-экономических и информационных систем. Формально рис. 2.7-2.9 и их описание скорее можно отнести к схемам, отображающим концептуальные положения их разработчиков. Преследуя более строгие, научные цели, настоящая работа обусловлена соответствующей методологической корректностью моделирования информационной инфраструктуры субъекта предпринимательства.

В процессе формирования общей методологии моделирования использованы академические принципы, изложенные в работе Н. П. Бусленко «Моделирование сложных систем» ${ }^{1}$. Синтез параметров и критериев модели информационного взаимодействия социально-экономической системы, субъекта предпринимательства основывается на теоретических положениях Р. Шеннона ${ }^{2}$. Основываясь на методологии моделирования и выше сформированных теоретических предпосылках, определена необходимость формирования теоретических принципов моделирования. Изложение их демонстрирует научную обоснованность синтезируемой модели управления информационной инфраструктурой, создает прозрачность теоретических подходов авторского коллектива в ее разработке. Более того, раскрытие промежуточных аспектов моделирования позволит продемонстрировать достоинства модели информационной инфраструктуры, основанной на парадигме управления.

Следуя академическому представлению о методологии моделировании и теории описания информационного поля социально-экономических систем, можно выделить итерационную последовательность (принципы) синтеза модели, выраженную через цель моделирования; объект моделирования; критерии адекватности (оптимальности) модели; параметры модели (признаки модели; тип модели); метод моделирования.

Цель моделирования определяет имитацию взаимодействия объектов и субъектов в рамках информационного поля предпринимательского формирования, как информационная инфраструктура системы управления. С научной точки зрения синтезируется имитационная модель социально-экономической системы. Фокус имитации - внутренние информационные потоки. Содержание потоков: управленческая информация. Оптимальность модели определяется качеством информационных потоков системы управления: минимальная численность взаимосвязей при максимальной пертинентности информационного содержания.

${ }^{1}$ Бусленко Н. П. Моделирование сложных систем. М.: Наука, 1988.

${ }^{2}$ Шеннон Р. Имитационное моделирование систем. Искусство и наука. М.: Мир, 1978. 
Объект моделирования определен как системный, то есть выражен через набор элементов и их взаимосвязи. Выделим элементы информационной инфраструктуры (рис. 2.11).

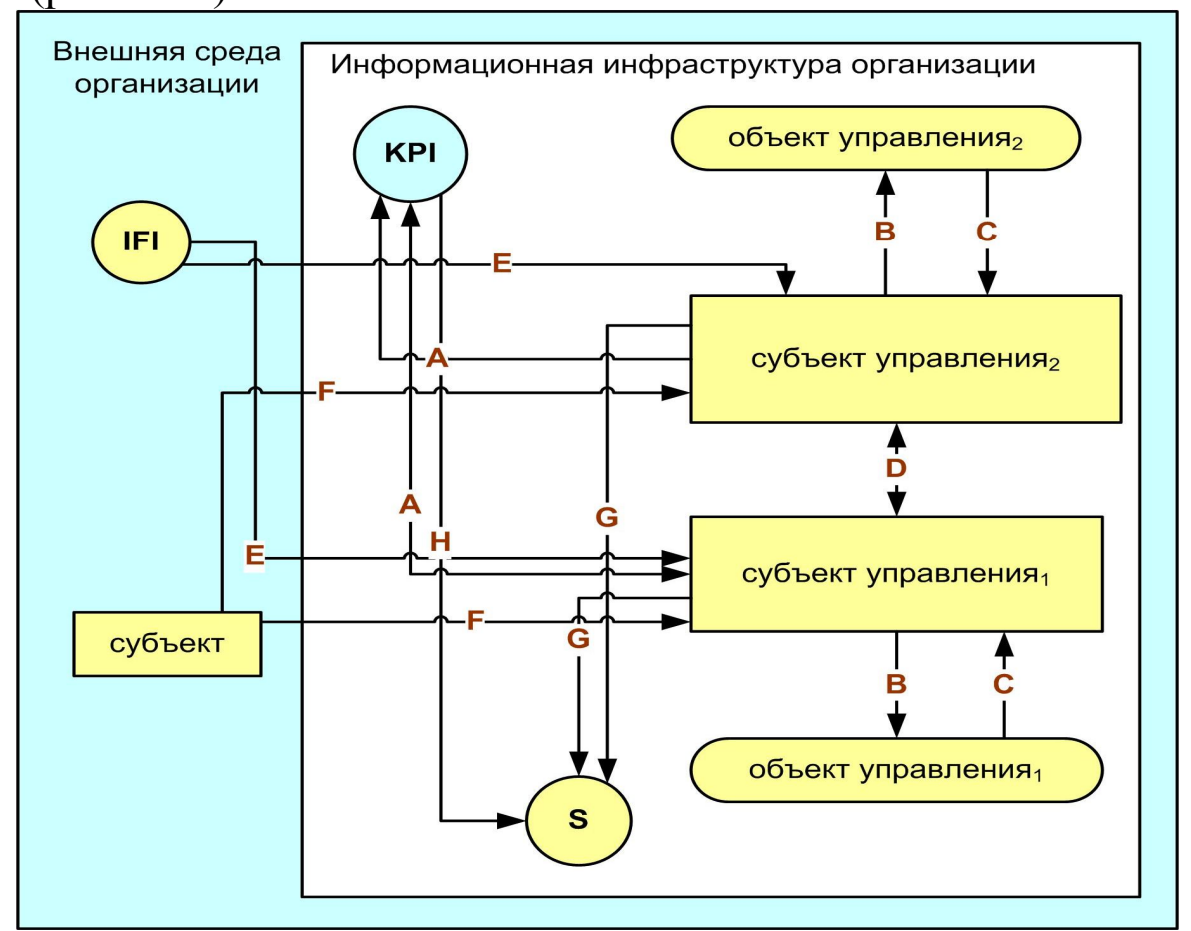

Рис. 2.11. Схема включенных в моделирование элементов: субъектов, объектов и их взаимосвязей

Исследование информационной инфраструктуры в рамках управленческого цикла компании подразумевает наличие объекта управления, под которым понимается ${ }^{1}$ предмет труда субъекта управления: материальный объект или процесс, преобразуемый в целевое состояние, под воздействием ресурсов системы, приведенных к заданному состоянию (прямая связь, $B$, см. рис. 2.11). Речь идет обо всех уровнях процессов управления в компании: закупка канцелярских принадлежностей, уборка помещений, выпуск промежуточных изделий, вывоз мусора, упаковка готовой продукции, администрирование, набор персонала и т. п. Здесь принимается позиция теории кибернетики о том, что любой процесс внутри компании рассматривается как управленческий, имеющий входы (ресурсы), цели системы (преобразуемый результат) и контур прямой и обратной связи. Объект управления обусловлен формализованными информационными потоками с качественными и количественными характеристиками.

Второй элемент системы - субъект (ы) управления, все сотрудники компании, включенные в управленческий процесс, относящиеся к объектам труда. Субъекты управления являются ключевыми элементами компании, ее информационной инфраструктуры, взаимодействуя как с объектами управления, так и с информационными объектами (см. рис. 2.11). Использование информационных потоков субъектами определяет целесообразность их нахождения в информационном поле. Информационные потоки и связи, не замкнутые на субъекта, определяются паразитными - они исключаются из модели информационной инфраструктуры. Входящие к субъекту информационные потоки являются основанием для подготовки

${ }^{1}$ Мелюхин И. С. Информационное общество: истоки, проблемы, тенденции развития. М.: Издво Моск. ун-та, 1999. 
решения, а исходящие рассматриваются как управленческая информация (сообщение), направленная на объект управления.

Объект целеполагания (KPI, см. рис. 2.11) включен в систему по наследству от прототипной модели (сбалансированная модель J. Pironti). Он является структурирующим признаком управленческой информации (см. рис. 2.10), фильтром ее целесообразности и востребованности в процессах управления, классификационным принципом информационной инфраструктуры субъекта предпринимательской деятельности. В фактическом компоненте компании КРI может представлять собой субъект, группу субъектов (подразделение, в контексте формирования и контроля $K P I$ - административно-управленческий аппарат компании), программно-вычислительный комплекс или комбинацию указанных элементов, являющихся носителем установочных целей по отдельным объектам управления и компании в целом. Понимание системы сбалансированных показателей в теории менеджмента ${ }^{1}$ определяется не только наличием формального документа, декларирующего целевые показатели управленческой деятельности компании, но и механизмов их достижения. Достижение целевых показателей реализуется их принятием и интеграцией в процесс управления реализуемый субъектами, то есть должно находить свое отражение на всех уровнях, во всех объектах управления. Информационные потоки системы управления должны выражать заложенные в KPI целевые показатели. Именно в этом выражается объектная сущность KPI механизмов - задание качественных и количественных параметров всех потоков в информационной инфраструктуре.

Объект обработки и накопления информации (S, см. рис. 2.11) рассматривается как элемент системы, обладающий компетенцией в области информационных технологий: методов и алгоритмов обработки, накопления и передачи информационных потоков. Аналогично объекту целеполагания, в фактическом компоненте субъекта предпринимательской деятельности он может представлять собой субъект, группу субъектов, программно-вычислительный комплекс или комбинацию указанных элементов. Целью объекта определяется повышение пертинентности информации, фильтрация потоков по технологическому принципу устранение шумов, дублирования, паразитной в информационном поле. Если объект целеполагания в системе можно рассматривать как реализующий процессы структурирования, управления содержанием, то объект обработки и накопления как технологический. Объект целеполагания представляет задачи менеджмента компании, нацелен на их реализацию, выражен в управленской компетенции. А объект обработки и накопления выражает компетенцию в области информационных технологий, реализуя процессы технологической обработки информации. Это во многом похоже на принципы информационной воронки в линейной модели информационной инфраструктуры Е. Monteiro (см. рис. 2.8): объект целеполагания выражен «аналитиком» по предметной области, а объект обработки и накопления «менеджером информации», то есть, выделены два объекта управления информационными потоками - содержательный и технологический.

Описанные объекты информационной инфраструктуры компании могут быть представлены в сводной форме (табл. 2.8).

\footnotetext{
${ }^{1}$ Нильс-Горан Ольве, Ро Жан. Сбалансированная система показателей...
} 
Таблииа 2.8

Объекты информационной инфраструктуры компании, включенные в моделирование

\begin{tabular}{|c|c|c|}
\hline Элемент & Описание & $\begin{array}{l}\text { Фактический компонент субъекта } \\
\text { предпринимательской деятельности }\end{array}$ \\
\hline $\begin{array}{l}\text { Объект } \\
\text { управления }\end{array}$ & $\begin{array}{l}\text { Элемент системы, на который относятся } \\
\text { трудовые процессы сотрудников } \\
\text { компании, выраженные как процесс } \\
\text { управления }\end{array}$ & $\begin{array}{l}\text { Трудовые процессы, } \\
\text { материальные объекты труда }\end{array}$ \\
\hline $\begin{array}{l}\text { Субъект } \\
\text { управления }\end{array}$ & $\begin{array}{l}\text { Субъект (личность, группа людей или } \\
\text { организация), принимающий решения и } \\
\text { управляющий объектами, процессами или } \\
\text { отношениями путём воздействия на } \\
\text { управляемую систему для достижения } \\
\text { поставленных целей }\end{array}$ & $\begin{array}{l}\text { Все сотрудники компании, } \\
\text { субъекты }\end{array}$ \\
\hline $\begin{array}{l}\text { Объект } \\
\text { целе- } \\
\text { полагания } \\
\text { (KPI на рис. } \\
2.11)\end{array}$ & $\begin{array}{l}\text { Выраженная через систему } \\
\text { сбалансированных показателей целевая } \\
\text { функция компании и отдельных объектов } \\
\text { управления }\end{array}$ & $\begin{array}{l}\text { Может быть представлен как } \\
\text { сотрудник компании, } \\
\text { подразделение, программно- } \\
\text { вычислительный комплекс или } \\
\text { комбинация указанных элементов }\end{array}$ \\
\hline $\begin{array}{l}\text { Объект } \\
\text { обработки и } \\
\text { накопления } \\
\text { информации } \\
\text { (S на рис. }\end{array}$ & $\begin{array}{l}\text { Объект, реализующий процесс } \\
\text { накопления, обработки и интерпретации } \\
\text { управленской информации }\end{array}$ & \\
\hline
\end{tabular}

Выделенные четыре элемента системы позволяют перейти к описанию их взаимосвязей. На этом этапе считаем необходимым обсудить один из параметров модели, признак «отношения системы к окружающей среде» ${ }^{1}$. Признак выражает систему как отрытую или закрытую. Модель информационной инфраструктуры субъекта предпринимательства понимается как открытая, то есть учитывающая информационные взаимодействия с внешней средой. В этой позиции основываемся как на современном видении организации ${ }^{2}$, так и на взглядах теории современного менеджмента ${ }^{3}$. Впрочем, и формальная логика подсказывает, что исключение внешних информационных потоков приведет к потере исходного содержания концепции информационной инфраструктуры, которая как раз и появилась как научная концепция повышения качества информации, метод фильтрации внешних первичных потоков. Информационные взаимодействия с внешней средой выражены со стороны субъекта управления системы: формализованная первичная информация (поток $E$, см. рис. 2.11), поступающая из информационных сетей IFI и неформализованная $F$, поступающая от внешних субъектов (экспертов, консультантов, знакомых и т. п. форм выражения межличностных коммуникаций). Элементы внешней среды («субъект» и IFI, см. рис. 2.11) очевидно не включаются в систему информационной

\footnotetext{
${ }^{1}$ Шеннон Р. Имитационное моделирование систем..

${ }^{2}$ Мильнер Б. 3. Теория организации: учебник...

3 Друкер П. Задачи менеджмента в 21-м веке...
} 
инфраструктуры из-за их «индетерминируемого хаотического характера» ${ }^{1}$ по отношению к субъекту предпринимательства. Предлагаем регламентировать в модели только входящие потоки $E, F$.

Вторым аспектом, на котором следует акцентироваться в описании объекта моделирования, является включенность, проявленность и регламентированность системы неформализованных информационных потоков между субъектами: поток .F и внутриорганизационный поток $D$. Данное положение продиктовано как критерием модели («выраженность роли субъектов управления и их информационного взаимодействия в организации»), так и очевидным пониманием роли личных контактов в формировании решений. Представленная в табл. 2.9 структура источников информации в управленческой деятельности субъектов предпринимательства, по данным исследований ВЦИОМ, наглядно показывает, что более $65 \%$ информационных потоков происходит в межличностном взаимодействии. Приведенные данные еще раз подчеркивают роль неформализованной информации, обмена знаниями между субъектами как важнейший элемент информационной инфраструктуры предпринимательских формирований.

Остальные информационные взаимосвязи (см. рис. 2.11) носят более очевидный характер и могут быть выражены вышеописанным содержанием и целью включения элементов системы (табл. 2.9). Взаимосвязи, их качественные и количественные параметры, содержание понимаются как информационные потоки, составляющие информационные поле субъекта предпринимательства. Если элементы системы - это объективная составляющая субъекта предпринимательства (сотрудники и объекты хозяйственной деятельности), влиять на которую при синтезе информационной модели не возможно (за исключением содержания деятельности объектов целеполагания и обработки - накопления), то информационные взаимосвязи как раз и рассматриваются как элемент оптимизации, взаимная организаџия которых и определяет модель информационной инфраструктуры.

Таблица 2.9

Источники информации в управленческой деятельности организации (2005)

\begin{tabular}{|l|c|}
\hline Источник & $\begin{array}{c}\text { Относительный уровень } \\
\text { использования. \% }\end{array}$ \\
\hline Личные контакты & $\mathbf{6 5 , 2}$ \\
\hline Деловая пресса & $\mathbf{4 3 , 8}$ \\
\hline Интернет & $\mathbf{3 4 , 7}$ \\
\hline Телевидение & $\mathbf{1 8 , 0}$ \\
\hline Маркетинговые исследования & $\mathbf{9 , 8}$ \\
\hline Отсутствие необходимости в информации & $\mathbf{7 , 0}$ \\
\hline Государственные консультационные центры & $\mathbf{3 , 8}$ \\
\hline Государственные службы & $\mathbf{2 , 4}$ \\
\hline Другое & $\mathbf{2 , 2}$ \\
\hline Услуги консалтинговых фирм и экспертов & $\mathbf{1 , 4}$ \\
\hline
\end{tabular}

Таким образом, описан объект моделирования: представлены элементы системы и их взаимосвязи. Оптимизация схемы взаимоотношений элементов 1986.

\footnotetext{
${ }^{1}$ Кузьмин И. В., Кедрус В. А. Основы теории информации и кодирования. Киев, Вища школа,
} 
системы рассматривается как задача моделирования.

Таблица 2.10

Информационные взаимодействия в модели информационной инфраструктуры субъекта предпринимательства (обозначения по рис. 2.11)

\begin{tabular}{|c|c|c|}
\hline $\begin{array}{c}\text { Обозна } \\
\text { чение }\end{array}$ & \multicolumn{1}{|c|}{ Содержание информационного взаимодействия } & Тип \\
\hline$A$ & $\begin{array}{l}\text { Информация о целевых показателях и показателях текущего состояния объекта } \\
\text { управления (двусторонняя). Задается объектом целеполагания, адресована } \\
\text { субъекту управления }\end{array}$ & $\Phi$ \\
\hline$B$ & $\begin{array}{l}\text { Управляющее информационное воздействие на объект управления («прямая } \\
\text { связь» - в кибернетических моделях) со стороны субъекта управления }\end{array}$ & $\Phi$ \\
\hline$C$ & $\begin{array}{l}\text { Информация о состоянии объекта управления («обратная связь»- в } \\
\text { кибернетических моделях) }\end{array}$ & $\Phi$ \\
\hline$D$ & $\begin{array}{l}\text { Обмен знаниями (неформализованной информацией) между субъектами } \\
\text { управления }\end{array}$ & НФ \\
\hline$E$ & $\begin{array}{l}\text { Получение субъектом управления внешней первичной информации от сетевых } \\
\text { информационных источников (внешних информационных объектов) }\end{array}$ & $\Phi$ \\
\hline$F$ & $\begin{array}{l}\text { Получение субъектом управления внешней первичной информации от субъектов } \\
\text { внешней среды (внешних информационных субъектов, экспертов, консультантов } \\
\text { и т. п.) }\end{array}$ & НФ \\
\hline$G$ & $\begin{array}{l}\text { Информация о результатах управленческой деятельности, поступающая от } \\
\text { субъекта управления к объекту обработки и накопления информации }\end{array}$ & $\Phi$ \\
\hline$H$ & $\begin{array}{l}\text { Задание объектом целеполагания системы структурирования информационных } \\
\text { единиц объектом накопления и обработки }\end{array}$ & $\Phi$ \\
\hline Примечание.Ф- формализованная; НФ - неформализованная & \\
\hline
\end{tabular}

Критерии адекватности модели. Модель носит качественный характер, обусловлена содержательной стороной и направленностью информационных потоков субъекта предпринимательства, что не отрицает возможности количественной оценки ее эффективности как целостной системы информационной инфраструктуры. Оптимизация взаимосвязей должна привести к росту пертинентности, формализованности межличностных потоков, сокращению времени на формирование управленческого решения, трансакционных расходов в итоге, что позволит оценить эффективность предложенных подходов. Но на первом этапе адекватность модели обусловлена качественными критериями (п. 2.2), которые выведены для анализа предложенных в научной литературе моделей. Они в равной степени относятся и на синтезируемую в настоящем исследовании модель управления информационной инфраструктурой:

Критерий 1. Ориентированность на акты управления и их последствия.

Критерий 2. Выраженность роли субъектов управления и их информационного взаимодействия в субъекте предпринимательства.

Критерий 3. Независимость от формализованности информации.

Критерий 4. Динамичность и эволюционность.

Параметры модели включают признаки и тип модели, обусловливают ее класс и выбор инструментов (методов) моделирования. Признаки модели - ее характеристики, позволяющие отнести модель к определенному типу ${ }^{1}$, сформировать

\footnotetext{
${ }^{1}$ Шеннон Р. Имитационное моделирование систем. Искусство и наука. М.: Мир, 1978.
} 
представления о граничных условиях синтеза. Рассмотрим следующие признаки, применительно к модели управления информационной инфраструктурой субъекта предпринимательства:

1. Отношение системы к окружающей среде. Модель открытая (позиция обсуждалась выше), информационная инфраструктура обусловлена влиянием внешних информационных потоков, формализованных и неформализованных. Но характер и состав внешних информационных потоков могут быть регламентированы. Современная компания не могут не использовать в своей деятельности внешнюю информацию (сетевую, экспертов и консультантов), не может зафиксировать данные потоки по определенному источнику, но может и должна организовывать регламент подобного взаимодействия, управлять процессом получения внешней формализованной и неформализованной информации. Хорошим примером может служить разработанный НИИУ ВНИЦ внутренний для группы компаний «Рестэк» регламент «Порядок работы с внешними экспертами». Документ носит как методический характер, так и регламентирующий, формирует порядок взаимоотношений с экспертом и методы проведения интервью. По количественной оценке директора ВНИЦ (М. В. Красавцев, 2007 г.), основанной на данных управленческого учета, эффект внедрения регламента выразился в сокращении затрат на экспертов и консультантов по группе компаний «Рестэк» на 17 \% (за 2006 г.).

2. Происхождение элементов системы. Естественная - объекты и субъекты носят естественный характер. Присутствие в системе описанных объектов и субъектов управления обусловлено не моделируемой информационной инфраструктурой, а самим фактом существования и содержанием деятельности компании. Сотрудники компании и объекты труда - объективные составляющие субъекта предпринимательства как социально-экономического феномена. Управление информационной инфраструктурой затрагивает порядок и принципы информационных взаимоотношений, но не меняет смысла и содержания деятельности субъекта предпринимательства.

3. Описание переменных системы. Переменные в описании модели носят качественный характер, обусловленный установленными критериями адекватности (п. 2.4). Модель отражает состав и направленность взаимосвязей элементов информационной инфраструктуры, качественным образом выражая достижение пертинентности информационных потоков. В описание информационных потоков включены источник, получатель и состав сообщения. Количественный объем сообщений (количество страниц в документе, размер компьютерного файла, частота их обновления во времени и т. п.) не влияет на эффективность информационной инфраструктуры, он учитывается вторично в проектировании мощности и емкости элементов обработки и накопления информации (численность персонала, состав вычислительной техники и т. п.). Но сформированная модель, основанная на качественных показателях (как это уже обсуждалась), вполне может быть характеризована количественными показателями эффективности. Показателями, основанными на целевой функции системы, определеннылии концепцией информационной инфраструктуры: сокращение объема информационных потоков и их внутренней стоимости, увеличение востребованности вторичной информации (по аналогии модели, предложенной для ЗАО «Мегастиль»).

4. Тип описания закона функционирования системы. Не параметризованная модель - в ней отсутствуют формальные экономико-математические отношения. Параметризация модели возможна при условии количественной интерпретации 
ценности, стоимости информации, но в настоящее время отсутствует достаточный научный базис ответа на данный вопрос. Вопрос ставился в научных исследованиях В. П. Федько, А. Б. Курицкого, А. С. Гриненко, R. H. Sprague, Е. D. Carlson, но все авторы приходили либо к пониманию «относительной ценности информации в конкретном контексте использования» ${ }^{1}$, либо к «рассмотрению только в контексте рыночного характера отношений» ${ }^{2}$, либо «экспертной оценки конкретного информационного сообщения ${ }^{3}$. Актуальность решения данной научной задачи (лежащей за пределами объекта исследования настоящей работы) определяется экономическим содержанием феномена информации (п. 1.1), который проявляется как предмет, средство и продукт труда в производственной деятельности. Следовательно, информация требует теоретического базиса оценки экономической утилитарности и стоимости. До решения задачи моделирование информационной инфраструктуры субъекта предпринимательства, впрочем, как и всех видов информационного взаимодействия в социально-экономических системах, будет носить не параметризированный характер. Именно поэтому вводятся количественные переменные, характеризующие пертинент-ность информации (эффективность фильтра, востребованность вторичной информации) и величину трансакционных расходов субъекта предпринимательства ${ }^{4}$. Но данные показатели позволяют оценить эффективность модели управления в целом, но не являются количественными факторами оптимизации взаимосвязей.

5. Способ управления системой - «управляемая снаружи». Информационная инфраструктура носит самоорганизующийся характер. Движение данных информационных потоков образует самоорганизованное информационное поле, инфраструктуру. В п. 2.2. было сформировано представление об информационной инфраструктуре как объективной реальности любой организованной системы. Таким образом, корректировка естественных информационных потоков и взаимосвязей есть внешнее вмешательство, управление снаружи системы, обусловленное целью повышения онтологической структурированности информационной системы

6. Учет фактора времени. Статическая модель. Движение информационных потоков субъекта предпринимательства во времени носит динамический характер, смешанный с точки зрения дискретности и монотонности (перманентности) распределения потоков. Более того, он обусловлен особенностями любого конкретного субъекта предпринимательства. Но данный аспект не попадает в сферу исследования информационной инфраструктуры, так как еe конфигурация не обусловлена относительным временем поступления информации. По аналогии: проектируем типовую схему охвата водоснабжением типового района - расположение водопроводных труб, водонапорных башен, насосов, но не оцениваем, когда и в какие точки будет поступать вода, и не учитываем мощность насосов и диаметр труб. Нас интересует география водопроводной системы, ее разветвленность и протяженность. Именно поэтому важен статичный срез информационной инфраструктуры расположение каналов связи и их конфигурация. Емкостные характеристики

\footnotetext{
${ }^{1}$ Курицкий А. Б. Интернет: инфраструктура информационного общества. СПб.: Судостроение, 1999.

${ }^{2}$ Гриненко А. С. Информационный банк бизнес-процессов предприятия //Сб. науч. тр. / Донская гос. академии сервиса. Шахты, 1999.

${ }^{3}$ Sprague R. H, Carlson E. D. Building Effective Decision Support Systems. Englewood Cliffs, NJ: Prentice-Hall, 1982.

${ }^{4}$ Асаул A. H, Иванов С. Н. Снижение трансакционных затрат в строительстве за счет оптимизации информационного пространства / под ред. А. Н. Асаула. СПб.: АЛО ИПЭВ, 2008.
} 
информационных потоков и их распределение во времени обнаруживаются и учитываются при наложении синтезированной модели на информационное поле конкретного субъекта предпринимательской деятельности.

7. Характер наблюдения процессов. Дискретная модель - фиксируется состояние информационной инфраструктуры в определенные моменты времени. Данное граничное условие, признак обусловлены дискретностью управленческих потоков субъекта предпринимательства на стратегическом и оперативном уровнях. В частности, в исследовательских экспериментах по замеру емкости информационных потоков (см. табл. 2.8) в качестве дискретного промежутка берем один год. Это объясняется двумя факторами. Во-первых, дискретностью и неравномерностью движения информационных потоков субъекта предпринимательства, отчетливо демонстрируемым на рис. 2.10. Впрочем, дискретность управленческих потоков отмечал еще основатель теории кибернетики Н. Винер ${ }^{1}$. Во-вторых, временной сосредоточенностью потоков информации, относимой $к$ стратегическому управлению. Бюджетирование, планирование деятельности субъекта предпринимательства сосредоточено на локальном временном промежутке, но генерирует относительно большие информационные объемы. Поэтому будет целесообразно рассматривать модель как дискретную, с оптимальным временным лагом в один год.

8. Уровень детерминированности. Синтезируемая модель детерминированная: «каждому входному набору параметров соответствует вполне определенный и однозначно определяемый набор выходных данных» ${ }^{2}$. Модель рассматривает структуру информационных взаимосвязей, детерминированность которой (структуры) определяется возможностью определить качественные параметры связи (отправитель, получатель, содержание связи). Ориентированность синтеза модели на данные параметры позволяет трактовать ее как детерминируемую.

9. Организация системы. Модель структурная, поскольку она представима структурой данных и отношениями между ними. Структура выражает оптимизируемые информационные взаимосвязи между субъектами. Предлагается синтезировать структуру информационного поля субъекта предпринимательства как базовую модель связей, компонующую необходимые элементы для реализации заложенной парадигмы - системы управляющих потоков.

Сформулированные признаки модели позволяют выбрать тип модели. В теории моделирования выделяют три типа моделей: .F-схема, D-схемa., Q-схема. Разделение на типы как раз и обусловлено различной компоновкой признаков. Предложенная выше совокупность признаков однозначно указывает, что модель управления информационной инфраструктурой относится к непрерывно-стохастическим (Qсхемы). P.

\footnotetext{
${ }^{1}$ Винер Н. Кибернетика, или Управление и связь в животном и машине. М.: Советское радио, 1958.
}

${ }^{2}$ Шеннон Р. Указ. соч. 


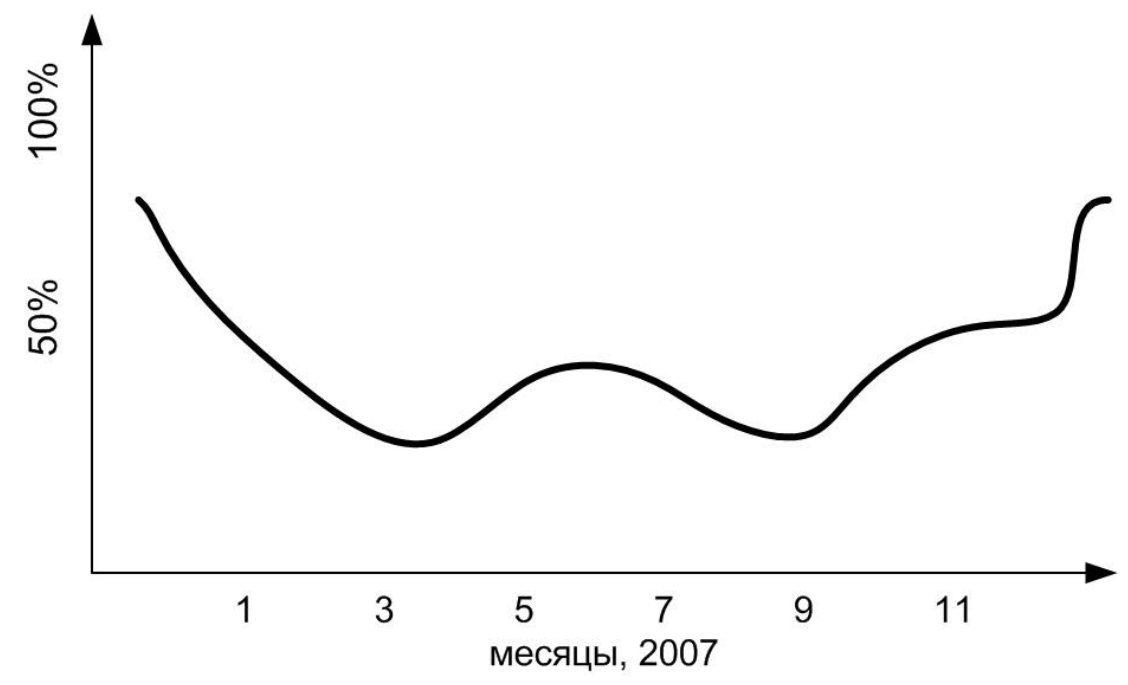

Рис. 2.12. Количество информационных единиц, поступивших в систему накопления (электронный вид - файл, учтено сервером сети) ЗАО «Мегастиль», 2007 $\Gamma$.

Шеннон их характеризует как «модели с неопределенным перманентным входящим потоком и динамичной структурой системы. Модели описывают равновесные неустойчивые системы с высоким уровнем неопределенности по качественным и количественным характеристикам возмущающих факторов». Внешние информационные потоки (сетевые, субъекты) являются возмущающими факторами в концепции информационной инфраструктуры и в полной мере характеризуются как неопределенные и перманентные. Реальная структура компании (состав и компоновка субъектов, объектов управления) является динамической: сотрудники меняются, их объекты труда также могут изменяться (изменение должностных позиций, содержания задач). Значит само современное видение компании, еe управленческой структуры, информационной инфраструктуры управленческого поля отвечает непрерывно стохастической модели как с позиций теории организации, так и с позиций кибернетики и менеджмента.

Методы моделирования Q-схем, структурных моделей носят вполне определенный характер - современные подходы выделяют сетевые диаграммы и структурные матрицы. Основным методом отображения принимаются графические методы отображения сетей, графов и деревьев. Математический инструментарий для Q-схем принимается как дополняющий, описывающий не столько компоновочные подходы, сколько характеристики модели в целом. Такой подход во многом отвечает настоящей задаче моделирования информационной инфраструктуры, которая, будучи не детерминированной, по количественным переменным взаимосвязям, может быть охарактеризована количественными показателями системы в целом (качество пертинентность, эффективность). Итак, очевидный выбор в нашем случае - сетевая диаграмма, позволяющая провести анализ устойчивости и мотивированности связей, развить прототипную модель, сформировать систему координированных управленческих информационных потоков.

Итак, предложены установочные параметры моделирования системы управления информационной инфраструктурой субъекта предпринимательства. Сформированные объекты, характеристики, критерии и признаки модели являются 
обоснованием результатов, представленных далее.

\section{4. СЕТЕВАЯ МОДЕЛЬ ИНФОРМАЦИОННОГО ВЗАИМОДЕЙСТВИЯ СУБЪЕКТА ПРЕДПРИНИМАТЕЛЬСТВА}

Сформированные принципы синтеза позволяют предложить сетевую модель информационной инфраструктуры, удовлетворяющей критериям адекватности. Название обусловлено ее обобщенными характеристиками, выражающими основные свойства, проявляемые по отношению к информационному взаимодействию в субъекте предпринимательской деятельности.

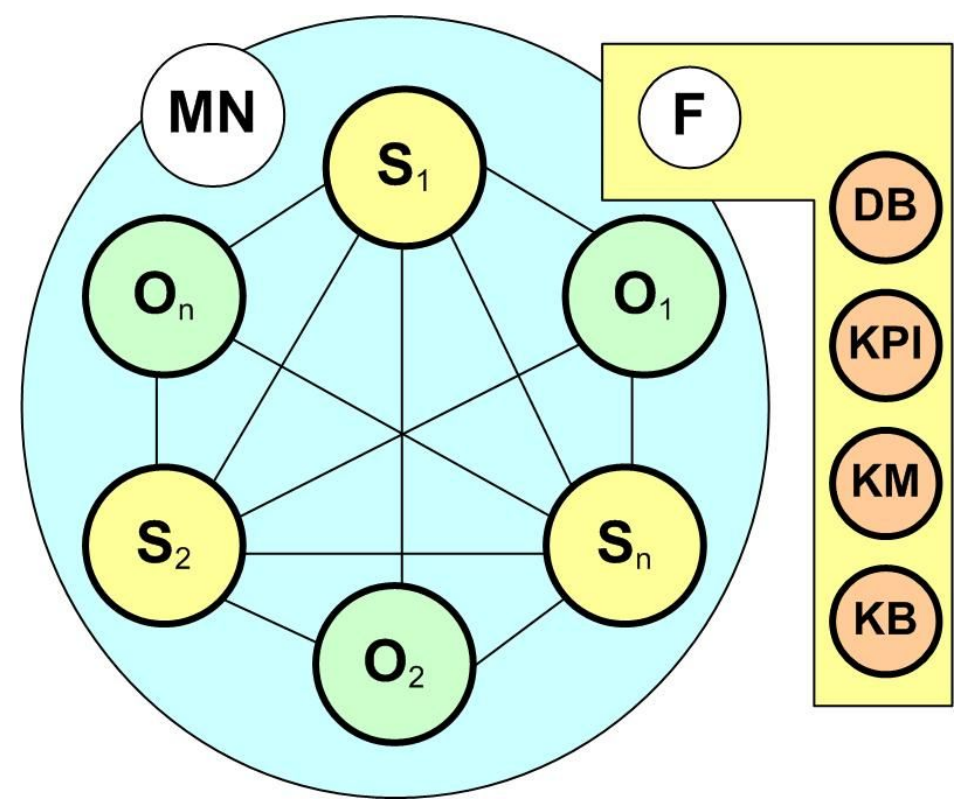

Рис. 2.13. Сетевой принцип информационной инфраструктуры субъекта предпринимательства (обозначения элементов по табл. 2.11)

В основе сетевого принципа организации информационной инфраструктуры лежит открытое, горизонтальное (информационное) взаимодействие субъектов управления ${ }^{1}$ (рис. 2.13). Субъекты обмениваются знаниями при подготовке решений, управляют «своими» объектами, получают информацию о состоянии «чужих» объектов. Причем допускается множественность объектов в управлении единичного субъекта, то есть ситуацию, когда один менеджер приходится на ряд объектов управления. Такая ситуация является типовой при матричной системе менеджмента субъекта предпринимательства ${ }^{2}$, а также в условиях проектного принципа

1 Здесь и далее не обсуждаются вопросы информационной безопасности, разграничения и иерархии доступа. При возникновении такой необходимости система разграничения доступа субъектов к информационным потокам определяется как еще один фактор сетевого распределения применительно к конкретному субъекту предпринимательской деятельности

2 Методология научных исследований в информационной инфраструктуре экономики: 
организации производственных процессов. Например, в ЗАО «Мегастиль» коммерческий директор руководит маркетинговыми и сбытовыми подразделениями (объект управления 1), выполняет маркетинговые функции в проекте «LED Technologies» (объект 2), ведет систему бюджетирования дизайнерского подразделения «BRIZ studio» (объект 3). У субъекта предпринимательства выражена множественность отношений субъектов и объектов управления, которая и интерпретируется в модели как управленческая сеть ( $M N$, см. рис. 2.13).

Таблица 2.11

Состав элементов и их обозначения в модели информационной инфраструктуры

\begin{tabular}{|c|c|}
\hline Обозначение & Содержание \\
\hline$M N$ & Управленческая сеть \\
\hline$S$ & Субъект управления \\
\hline$O$ & Объект управления \\
\hline$F$ & Модуль структурирования и управления \\
\hline KPI & Объект целеполагания \\
\hline$\overline{D B}$ & База данных \\
\hline$K M$ & Менеджер знаний, субъект \\
\hline$\overline{K B}$ & База знаний \\
\hline
\end{tabular}

Управленческая сеть является первичным самоорганизующимся элементом информационной инфраструктуры субъекта предпринимательства, включающим формализованные и неформализованные внутренние информационные потоки, взаимодействующие с внешней информационной средой (внешними сетями и субъектами). В предложенной сетевой модели информационное поле субъекта предпринимательства понимается как система управленческих взаимодействий, что соответствует развитой в настоящей работе информационной парадигме субъекта предпринимательства - управленческой. Совокупность парадигмы и сетевого принципа информационных отношений определяет первичное отличие предложенной модели от прототипа.

Перевод от самоорганизованной сети (MN) к онтологически упорядоченной информационной инфраструктуре реализуется включением в модель внешнего модуля управления. В модели он назван «модулем структурирования и управления» $(F$, см. рис. 2.13), что отражает цели его функционирования. Задача модуля определяется как повышение эффективности функционирования управленческой сети субъекта предпринимательства, выраженной в повышении качества управленческих информационных потоков. Качество достигается упорядочиванием формализованных потоков и организацией системы обмена и накопления неформализованных сведений, знаний. Методически задача реализуется включением и взаимной конфигурацией четырех элементов модуля: объекта целеполагания, базы данных, менеджера знаний (субъект), базы знаний. Рассмотрим содержание и сущность данных элементов в сетевой модели информационной инфраструктуры субъекта предпринимательства.

Объект целеполагания (KPI, см. рис. 2.13) задает количественные параметры, выражающие цели функционирования субъекта предпринимательства и составляющих ее объектов управления (более подробно см. п. 2.3). Представляет 
собой субъект, программно-аппаратный комплекс или их комбинацию, являющихся носителями целей функционирования системы. Формулировка целей основана на «системе сбалансированных показателей» ${ }^{1}$. В системе функционирования информационной инфраструктуры KPI выполняет фильтрующую функцию по отношению к информационным потокам: отсекает внешние паразитные потоки информации, выделяет внутренние информационные единицы (формализованные и неформализованные), имеющие управленческую ценность с точки зрения обработки и накопления.

Методически принципы внедрения системы сбалансированных показателей и их интеграция в информационную инфраструктуру может быть основана на алгоритмах Нильса-Горана Ольве и Жана $\mathrm{Po}^{2}$.

База данных рассматривается как элемент накопления формализованной управленческой информации с высокой пертинентно-стью. Пертинентность реализована использованием программно-аппаратных средств (баз данных) и их структурированием на основе системы сбалансированных показателей. Целевые показатели KPI могут рассматриваться как ключевые поля связанных информационных данных, аналогично фрагменту базы данных компании «Мегастиль», представленному на рис. 2.14. База данных рассматривается как первичный элемент управленческой сети, содержащий формализованную информацию об управленческих актах. Управленческие воздействия носят строго формализованный характер, выраженный формализованным потоком информации к объекту управления: выполнение операции (да/нет), объем затрат на управленческое решение (сумма) и т. д. Аналогично формализованы и результаты управленческих актов, которые характеризуют состояние объекта управления: объем продаж, объем выполненных операций и т. п. С экономической точки зрения, любой бюджет может рассматриваться как управленческая модель ${ }^{3}$ : затраты как количественные показатели актов управления, а доходы (поступления) как количественные показатели результатов управления, состояния объекта управления, то есть акты управления могут носить количественные экономические характеристики, быть формализованы в количественные сведения, имеющие высокую пертинентность. Именно эти научные выводы определяют место элемента «база данных» в модели информационной инфраструктуры. Управление формализованными потоками не требует явного субъекта управления сведениями в силу формализованного регламентированного характера информации. Впрочем, не отрицается и возможность его наличия, если это обусловлено технологической потребностью. Но менеджер информации в настоящей модели не включен в информационную инфраструктуру, рассматривается как технологическое звено для поддержания работоспособности аппаратно-программных комплексов.

\footnotetext{
${ }^{1}$ Рыночная инфраструктура: состав, функции, взаимодействие с предприятиями: материалы науч.-практ. конф. с междунар. участием / под ред. А. И. Матвеева. СПб.: СПбДНТП, 1992.

${ }^{2}$ Нильс-Горан Ольве, Жан Ро. Указ. соч.

${ }^{3}$ Гуртов Д. В. Информационная инфраструктура: монография. М.: Изд-во РАГС, 2006.
} 


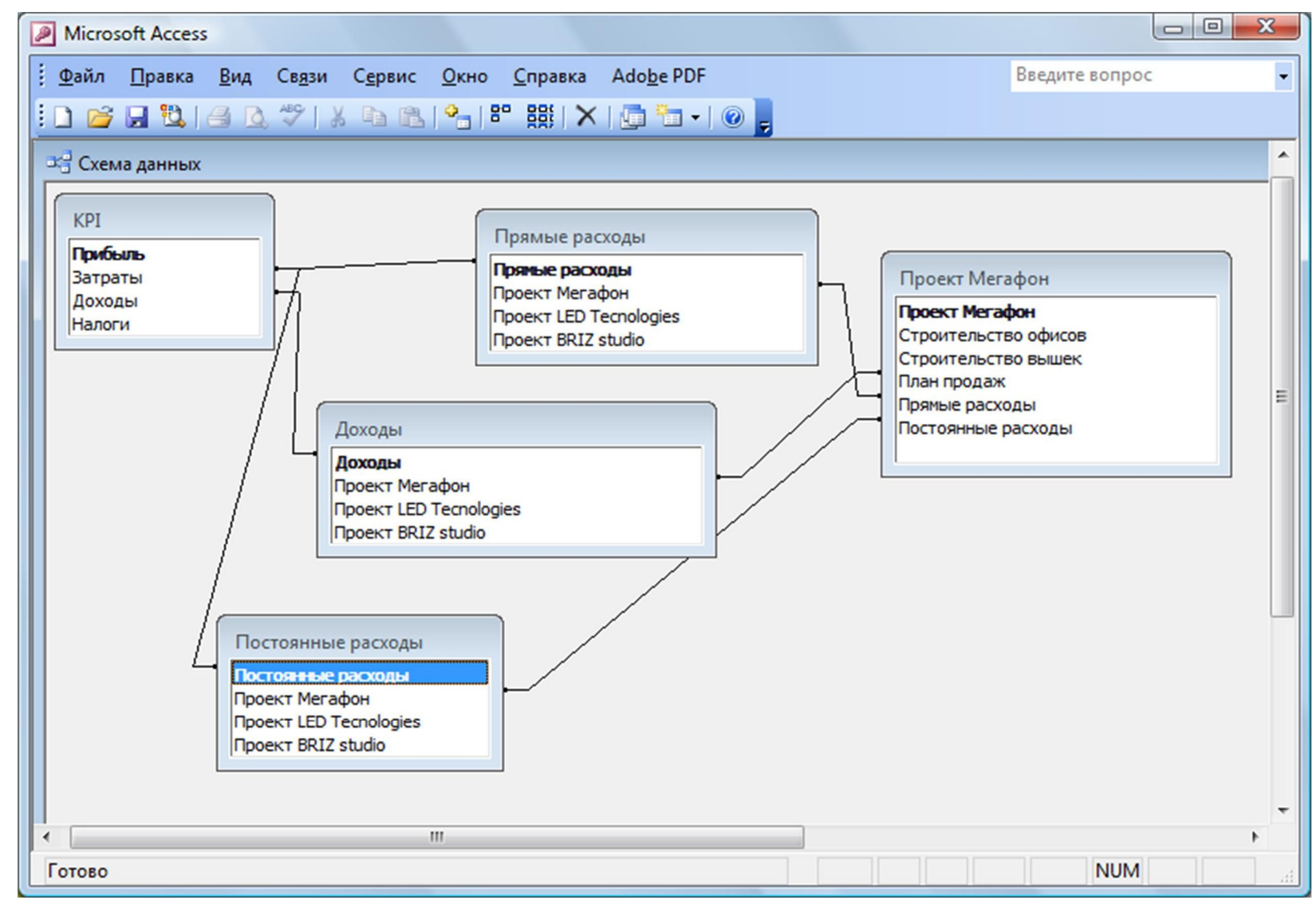

Рис. 2.14. Фрагмент базы данных $3 А О$ «Мегастиль» в рамках реализованной сетевой модели информационной инфраструктуры, структурированной на основе системы сбалансированных показателей

Стратегической основой развития современных социально-экономических систем является обмен знаниями между ее субъектами, управление неформализованными межличностными потоками информации, объем которых составляет более $60 \%$ емкости информационного поля субъекта предпринимательства. Но не только их емкостные характеристики определяют внимание к знанию, но и стратегическое значение как ресурса экономического развития субъекта предпринимательства. П. Друкер определяет данный ресурс как ключевой в современной системе менеджмента.

«Большинство ресурсов не являются специфичными: капитал, оборудование, материальные ценности - не могут быть использованы для того, чтобы отличить один бизнес от другого по своей глубинной сути. Самый главный ресурс, отличающий бизнес и дающий решающие конкурентные преимущества - это используемые в нем специфические производственные и управленческие знания» ${ }^{11}$. Солидарность с данной позицией определяет включение в модель информационной инфраструктуры контура управления знанием (неформализованной информацией) и соответствующие элементы его интерпретации (менеджер знаний), создание знаний и накопления их (база знаний).

Менеджер знаний. Включение менеджера знаний в модуль управления

${ }^{1}$ Друкер П. Задачи менеджмента в 21-м веке / пер. с англ. М.: Изд. Дом «Вильяме», 2000. 272 c. 
информационной инфраструктуры обусловлено задачей упорядочивания неформализованных информационных потоков, организацией обмена знаниями, опытом субъектов. В отличие от формализованной управление неформализованной информацией требует промежуточной личностной интерпретации, основанной на теории и методах менеджмента знаний. Менеджмент знаний ${ }^{1}$ исследует принципы и формирует научные методы управления знаниями субъекта предпринимательства для превращения их в инструменты принятия эффективных операционных и стратегических решений. Знание, в отличие от традиционного представления о формализованных данных, имеет выраженную специфику. И. Но-нака и Х. Такеучи, основатели теории менеджмента знаний, выражают его специфику следующим

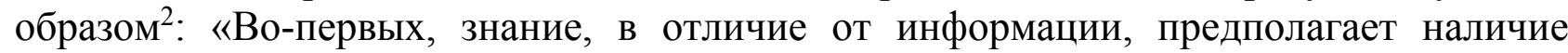
мнения и убеждения. Знание - функция определенной позиции, точки зрения или намерения. Во-вторых, знание, в отличие от информации, подразумевает действие. Это всегда знание «ради какой-то цели». В-третьих, и знание и информация подразумевают значение и имеют зависящий от ситуации и относительный смысл».

Указанные особенности знания выражены в специфике и методах его формализации, инструментах его накопления и распространения в компаниях. Задача, стоящая перед менеджером знаний, состоит в управлении процессами передачи знаний между субъектами, интерпретации знаний в формализованную форму для накопления (база знаний) и обезличенной передачи.

Например, субъект управления «А» имеет успешный опыт продаж, исключительный для компаниях. Менеджер знаний исследует его (опыт) и определяет, что ключевыми факторами успеха являются: метод составления субъектом коммерческих предложений, навыки выделения перспективного потребителя и риторически правильная аргументация в процессе продаж. Для распространения знаний (опыта, методов и навыков) субъекта «А» менеджер знаний в рамках мотивированного сотрудничества с субъектом, сотрудником компании, интерпретирует, формализует и фиксирует в базе знаний метод составления коммерческих предложений; включает в обязанности субъекта (мотивируя и выделяя соответствующее рабочее время) внутриорганизационное консультирование; привлекает субъекта «А» для проведения внутренних тренингов для других сотрудников по выделению потребителей и аргументации продаж. В процессе проведения тренингов фиксирует формализуемые аспекты таковых и включает их в базу данных. В данном примере видно, что знание распространяется как методами межличностных контактов, так и обезличенно через накопленные и формализованные в базе знаний сведения (подробнее см. п. 3.4).

Методы интерпретации знаний на сегодняшний день развиваются в рамках специальных разделов теорий менеджмента знаний, экспертных оценок и информационных технологий. В рамках предложенных в научной литературе подходов ${ }^{3}$ можно судить о значительном теоретическом и методическом базисе интерпретации и трансфера знаний, обоснованной возможности включения и реализации модуля работы с неформализованными сведениями в синтезируемой

1 Липин Ю. Н. Базы данных и знаний. Управление базами и защита информации: учеб. пособие. Пермь: Изд-во Перм. гос. техн. ун-та, 2008.

${ }^{2}$ Нонака И., Такеучи Х. Компания - создатель знания. Зарождение и развитие инноваций в японских фирмах / пер. с англ. М.: ЗАО «Олимп-Бизнес», 2003.

3 Липин Ю. Н. Указ. соч.; Лунева О. В. Общение // Знание. Понимание. Умение. 2005; Сараев А. Д., Щербина О. А. Системный анализ и современные информационные технологии // Тр. Крымской АН. Симферополь: СОНАТ, 2006. 
модели. В зарубежных компаниях менеджер знаний становится привычным сотрудником с вполне понятным набором задач и компетенций ${ }^{1}$.

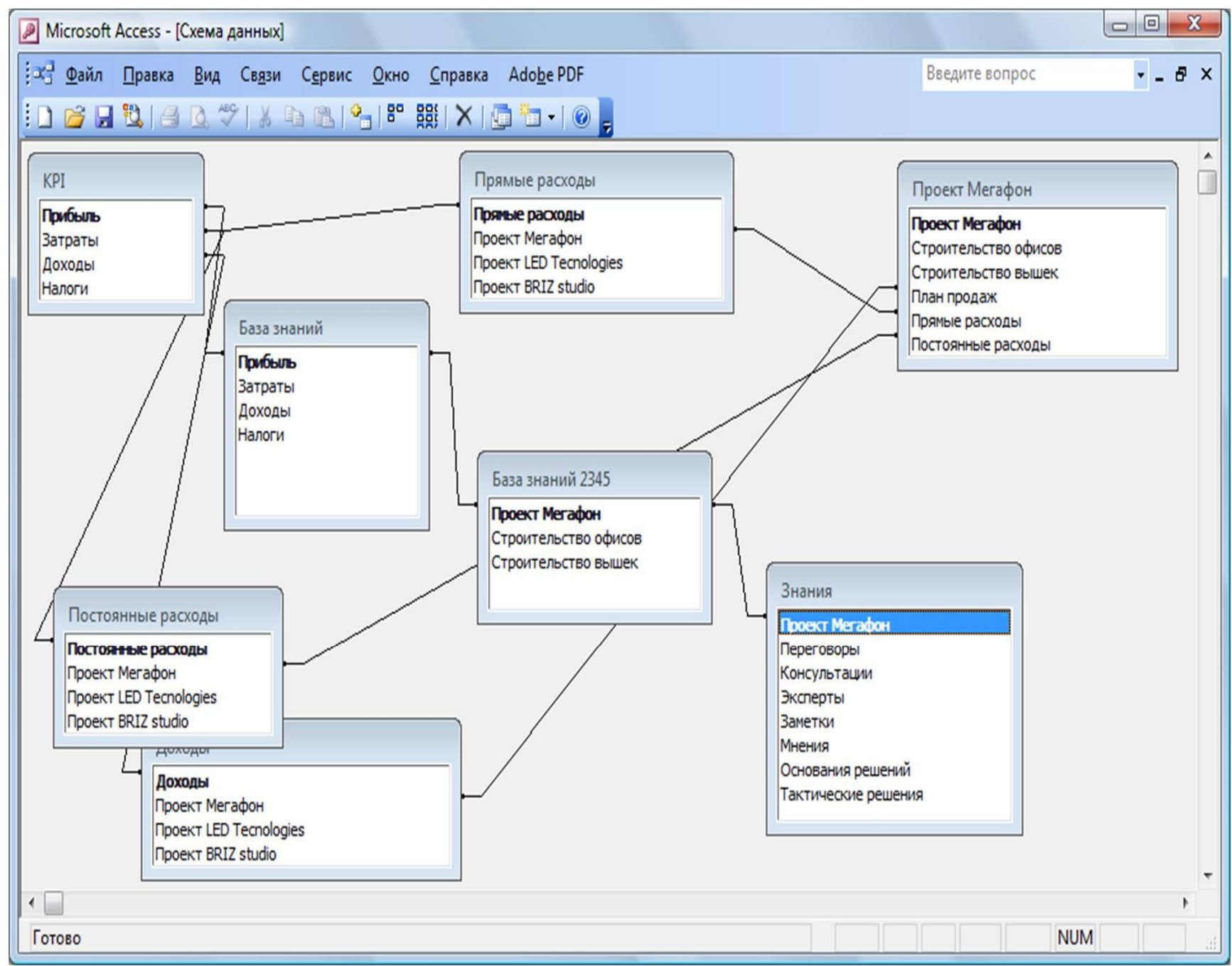

Рис. 2.15. Фрагмент программно-аппаратной интеграции баз данных и знаний $3 \mathrm{AO}$ «Мегастиль» в рамках реализованной сетевой модели информационной инфраструктуры

База знаний понимается как программно-аппаратный комплекс, содержащий формализованную информацию о ситуациях, косвенно выражающих имплицитные (скрытые) навыки, умения, опыт, компетенции персонала субъекта предпринимательства. База знаний в ее фактическом воплощении, формируемая менеджером, может рассматриваться как некий набор кейсов, ситуаций, качественных описаний, примеров управленческих решений, знакомство с которыми помогает субъекту сформировать собственные методы принятия решений. С техническими аспектами и методами организации сведений в базах знаний можно познакомиться в специальной литературе по данному вопросу ${ }^{2}$. В косвенном виде база знаний содержит компетенцию субъектов управления, субъекта предпринимательства в

${ }^{1}$ Weill P, Broadbent M. Leveraging the New Infrastructure: How Market Leaders Capitalize on Information. Boston: Harvard Business School Press, 1998.

2 Дулин С. К., Киселев И. А. Моделирование сходства элементов базы знаний: монография. М., 1994. 
целом. Она ориентирована на обезличенный способ передачи знаний между субъектами. Например, в ЗАО «Мегастиль» база знаний была очень эффективна при передаче знаний сотрудникам региональных подразделений, личностный контакт и передача опыта которым по естественным причинам затруднена.

В отношении базы знаний применяется тот же структурирующий принцип, что и в отношении базы данных - система сбалансированных показателей (KPI). Именно поэтому в программно-аппаратном решении база данных и база знаний могут быть объединены в единое технологическое решение, подобное представленному на рис. 2.15 для предприятия «Мегастиль» (подробнее см. п. 3.4).
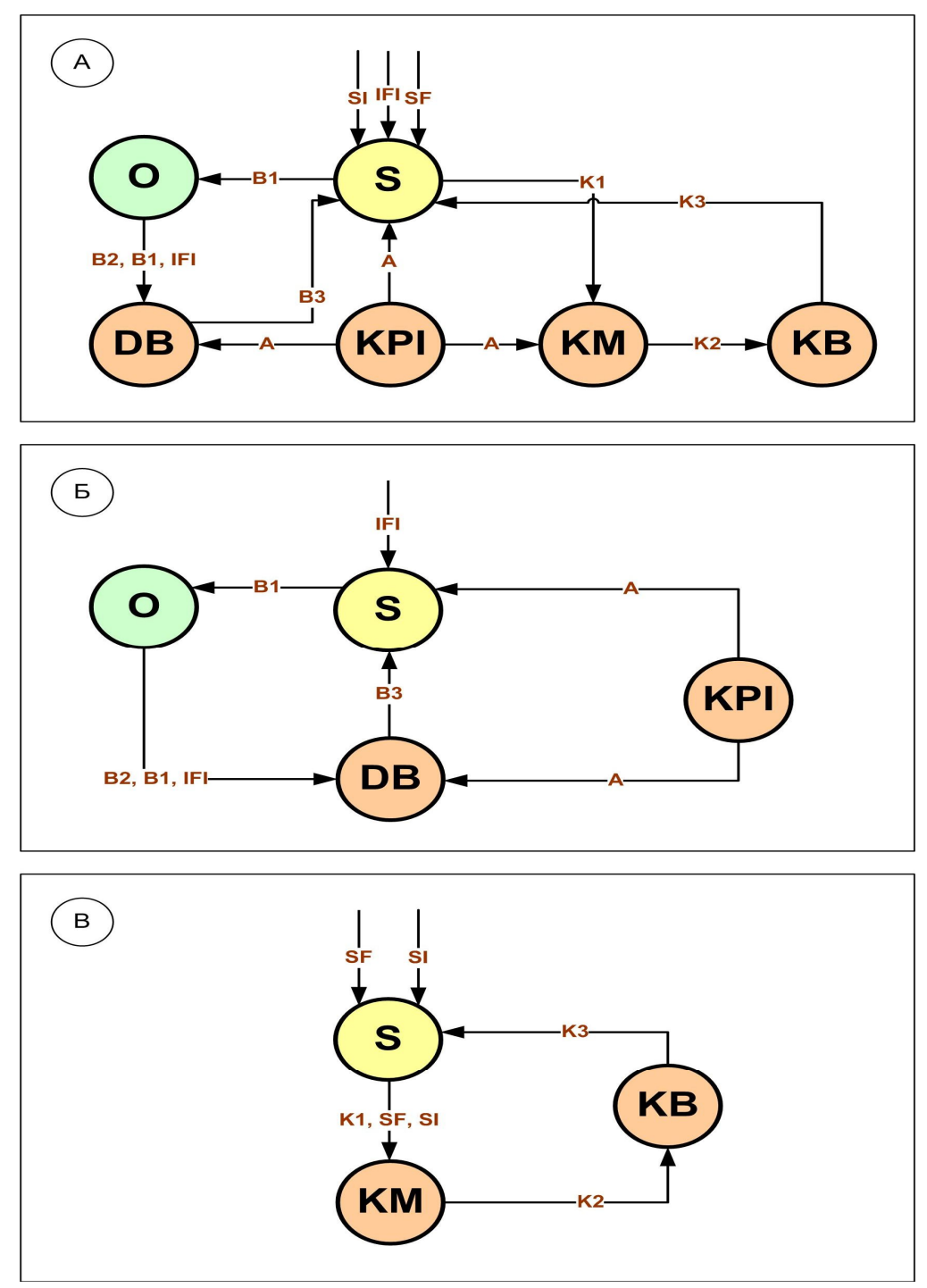

Рис. 2.16. Модель информационной инфраструктуры субъекта предпринимательства (А), контуры формализованных (Б) и неформализованных (В) информационных потоков (обозначения элементов по табл. 2.5 , взаимосвязей - в контексте параграфа)

Итак, представленные элементы и общие свойства модели информационной инфраструктуры позволяют перейти $к$ более строгому описанию ее функционирования. Сетевая диаграмма (Q-схема) модели представлена на рис. 2.16, 
A, включающая отображение формализованного контура (рис. 2.16, Б) и неформализованного (трансфер и обмен знаниями) контура (рис. 2.16, В) информационных потоков.

Описание функционирования информационной инфраструктуры субъекта предпринимательства основано на объяснении содержания еe информационных потоков, взаимосвязей между элементами (узлами) информационной сети.

Первичным информационным потоком, задающим содержание сетевого управленческого взаимодействия, является информация о целевых показателях объектов (О) управления - поток А (см. рис. 2.16), инициируемый и транслируемый элементом целеполагания (KPI). «Система сбалансированных показателей» - это формализованные переменные, выражающие количественные и качественные параметры ожидаемого состояния управляемой системы, структурирующий принцип субъекта предпринимательства сведений и данных информационной инфраструктуры, фильтр пертинентности информационных единиц. Ключевое значение $K P I$ выражается через единый по содержанию поток $(\mathrm{A})$, ориентированный на три элемента: субъекты управления $(\mathrm{S})$, менеджер знаний $(K M)$, база данных $(D B)$. Данные три элемента замыкают на себя, управляют в оперативном контуре (см. рис. 2.16 , Б и В) потоками формализованной и неформализованной информации в инфраструктуре субъекта предпринимательства. Информационное поле подчинено цели управления организацией, содержание потоков носит управленский характер, а система рассматривается как ключевой элемент системы менеджмента. Данный подход в модели выражает преемственность принципов современного менеджмента, экономическое содержание и направленность разработанной модели информационной инфраструктуры.

Модель информационной инфраструктуры содержит два контура: формализованной и неформализованной информации. Разделение обусловлено различиями структурного содержания, методов обработки и накопления информационных единиц в контурах.

Контур формализованной информации (см. рис. 2.16, Б) очевидно может быть представлен как кибернетический, в котором все единицы, переменные имеют количественное выраженное. Субъект (S) в формировании управляющего воздействия руководствуется информацией (поток А) о целевом состоянии объекта (O). Учитывает внешнюю формализованную информацию (IFI, внешняя первичная информация) в формировании управляющего воздействия (-B1). Поток $B$ рассматривается как «прямая связь в контуре управления», выраженная формализованным значением: объем затрат, регламентированный акт изменения свойств объекта и т. п.

Обратная связь объекта управления (В2) носит такой же формализованный характер - возвращает результат изменения целевого фактора: объем продаж, объем затрат, формализованное свойства объекта и т. п. Заметим, что в предложенной модели информационный поток обратной связи возвращается к базе данных, выполняющей «мониторинговую» функцию в кибернетическом контуре. Этим обусловлено накопление в нем параметров исходной цели управления (А), информационных оснований принятия решения (JFI), формализованных управляющих воздействий со стороны субъекта (-B1), результатов цикла управления (-В2) - состояния объекта. Пример содержания информации в контуре формализованных сведений представлен на рис. 2.17. 


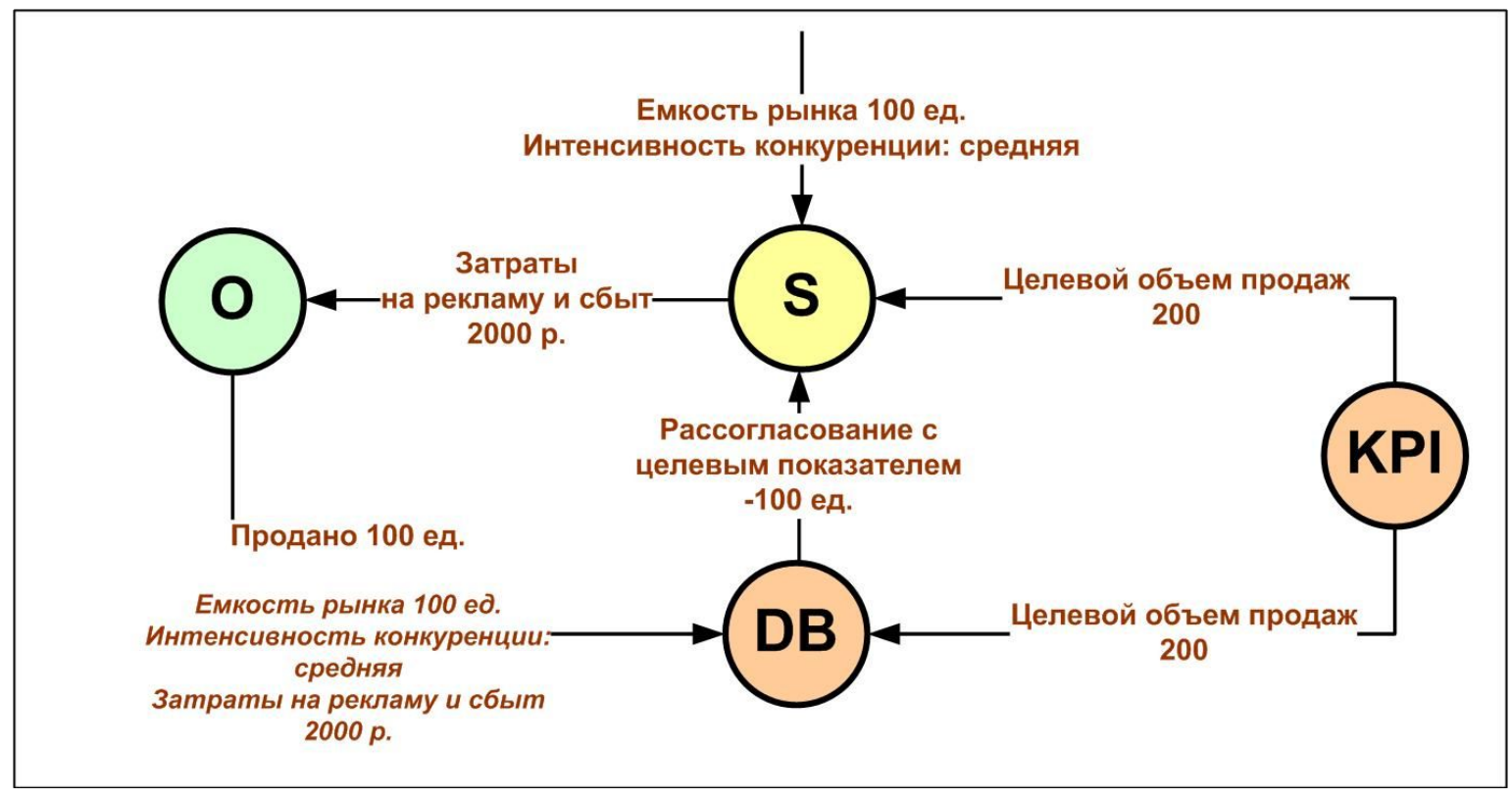

Рис. 2.17. Пример содержания информации в контуре формализованных сведений

База данных выполняет мониторинговую и первичную аналитическую функции контура управления, возвращая субъекту результат управленческого воздействия (поток $B 3$ ). Анализ сведений субъектом, привлечение актуальных потоков внешней первичной информации (IFI) приводит к формированию нового управленческого воздействия, второго цикла. В итоге видим замкнутый контур управления, основанный на формализованных потоках информации.

В обсуждении формализованного контура явно читается информационный пробел. Согласно примеру (см. рис. 2.17) субъект получил информацию о том, что его управляющее воздействие не достигло цели (рассогласование с целевым показателем, поток В3). Допустим, во втором цикле управления он решил руководствоваться линейным принципом (только формализованной информацией) и увеличил объем воздействия (B2 - объем затрат на рекламу и сбыт) в два раза. И во втором цикле опять же не достигает целевого результата. Возникает управленческая дезориентированность (кризис) - непонимание методов, факторов и способов управления. Именно на этом этапе вынужденно возникает обращение к контуру неформализованной информации.

Для формирования управленческого воздействия субъект привлекает неформализованную информацию и обращается к знаниям из трех источников (см. рис. 2.16, В), представленных по степени понижения пертинентности:

1. Сведения в базе знаний (поток $K 3$, см. рис. 2.16, В) в поиске косвенной информации по возникшей управленческой ситуации (примеры управленческой деятельности коллег, описания успешных результатов других организаций и т. п.). Данный источник информации для субъекта является наиболее кратким и эффективным путем поиска ответа, так как информация в базе знаний структурирована элементом целеполагания (KPI). То есть, весь массив информации в базе знаний структурирован по актам управления - субъект выделяет свой тип управленческого решения и обращается к накопленным единицам информации по данному вопросу. 
2. Внутренние прямые личностные коммуникации с другими субъектами управления субъекта предпринимательства (SI, см. рис. 2.16, В). Данный источник обладает высокой эффективностью, так как является прямой передачей знания (опыта, компетенций и интуиции коллег) применительно к конкретной ситуации управления. Но обладает относительно низкой пертинентностью из-за наличия шумов, обусловленных межличностным контактом (личные отношения, отвлеченные рассуждения и т. п.).

3. Внешние прямые личностные коммуникации (SF, см. рис. 2.16, В) со сторонними субъектами (эксперты, консультанты, лица, осведомленные о ситуации управления). Данный источник обладает как низкой пертинентностью (обусловленной все теми же межличностными факторами), так и относительно низкой эффективностью. Обнаруживаемая низкая эффективность обусловлена недостаточным уровнем понимания внутренних факторов субъекта предпринимательства, конкретной управленской ситуации.

Совокупность трех источников неформализованной информации формируется в дополнительное (по отношению к формальным переменным управления) основание управленческого решения. Заметим, что субъект управления в модели является консолидирующим элементов по отношению ко всем типам информационных потоков, фильтром их пертинентности. В данном случае его можно считать рациональным (эффективным) фильтром, поскольку он ориентирован на успешность акта управления.

Далее, если сформированное на основе информационных источников управляющее воздействие (-В1) оказывается успешным (мониторинг потока -В3), менеджер информации (KM) вступает в сотрудничество с субъектом. Целью сотрудничества со стороны менеджера знаний определяется фиксация в базе знаний неформализованной информации (потоки $K 1$, интерпретированные субъектом $S F, S I$ ), определившей успешность управленческого акта для последующего тиражирования знания в виде потока КЗ Менеджер информации старается получить от субъекта как можно больше сведений для размещения в базе знаний (поток $K 2$ ), полученных во внутриорганизационном и внешнем взаимодействиях. Информация, которая была им получена, но не использована в формировании решения, может быть использована другими субъектами при обращении к знаниям. Именно данное действие замыкает контур движения неформализованной информации, накапливая сведения в базе знаний.

Итак, можно видеть, что сетевая модель информационной инфраструктуры выражена как управленская, ориентированная на акты принятия решений взаимосвязанными субъектами субъекта предпринимательства. Выраженность контуров формализованной и неформализованной информации позволяет их регламентировать и мотивировать в фактической социально-экономической системе. Определенность модели, ее соответствие критериям адекватности очевидно и позволяет перейти к вопросу о методах управления информационной инфраструктурой субъекта предпринимательства, целевым количественным показателям ее состояния. 


\section{Глава 3 \\ МЕТОДЫ ФОРМИРОВАНИЯ СИСТЕМЫ СОЗДАНИЯ \\ И ЭФФЕКТИВНОГО УПРАВЛЕНИЯ \\ ОРГАНИЗАЦИОННЫМ ЗНАНИЕМ (ССУОЗ) \\ В ПРЕДПРИНИМАТЕЛЬСКИХ ФОРМИРОВАНИЯХ}

\section{1. ИСПОЛЬЗОВАНИЕ МЕТОДОЛОГИЧЕСКИХ ПРИНЦИПОВ ТЕОРИИ ДЕЯТЕЛЬНОСТИ В ПРОЦЕССЕ СОЗДАНИЯ, НАКОПЛЕНИЯ И ПЕРЕДАЧИ ОРГАНИЗАЦИОННОГО ЗНАНИЯ}

Одной из аксиом науки как некой модели реальности, конкретизируемой в предметных областях любого из научных направлений, право на существование которой не требует построения системы доказательств, является утверждение, что «...методология должна всегда предшествовать отдельным или групповым техническим приемам исследования, т. е. методам исследования. Нельзя логический подход смешивать с инструментами анализа. Методология и методы образуют последовательные ступени экономического анализа, процесса познания хозяйственной жизни общества» ${ }^{1}$. В данном случае взаимодействия субъектов предпринимательства и являются именно той моделью. Именно поэтому изучение проблем взаимодействия субъектов предпринимательства как объекта экономической науки объективно требует выбора некой совокупности методологических принципов или методологии, способной выполнить не только объяснительную, но и предсказательную функцию.

Родоначальником деятельностного подхода, по оценкам исследователей в области научной методологии ${ }^{2}$, является $Г$. Гегель. Проецируя на принцип деятельности всю человеческую историю, он придал ей структурно-развернутое выражение через категории «цели», «средства», «результаты». Как отмечает Э. Г. Юдин, «...такое представление... существенно расширило объяснительные возможности понятия деятельности...», так как позволило, во-первых, «...по-новому очертить контур реальности...», в которой первичным стал не сам факт существования индивидов, а наличие «...глубокой содержательной связи между ними...». Во-вторых, именно деятельность стала рассматриваться как источник и механизм организации такого рода связей в сообществе людей, где индивид предстает как «орган деятельности». В-третьих, структурное расчленение деятельности на цели, средства, результаты дали возможность теоретического объяснения множества явлений в реальной действительности.

Существенный вклад в ее создание внесли такие ученые, как И. В. Блауберг, С. В. Емельянов, Э. Л. Наппельбаум, В. Э. Мильман, Г. П. Щедровицкий, Э. Г. Юдин и

${ }^{1}$ Асаул Н. А. Методические принципы институциональных взаимодействий субъектов рынка как открытых «живых» систем в концепции информационного общества. М.; СПб.: «Вольное экономическое общество России», 2004.

${ }^{2}$ Климов С. М. Интеллектуальные ресурсы общества. СПб.: ИВЭСЭП, Знание, 2002; Щедровичкий $Г$. П. К характеристике наиболее абстрактных направлений методологии структурносистемных исследований // Проблемы исследования систем и структур. М.: АН СССР, 1965.; Юдин Э. Г. Деятельность и системность // Системные исследования: ежегодник. М.: Наука, 1976; Системный подход и принципы деятельности. Методологические проблемы современной науки. М.: Наука, 1978. 
другие ${ }^{1}$. Фундаментально же эта методология опирается на работы А. Н. Леонтьева, Л. С. Выгодского, А. Р. Лурия и других.

Современный этап развития научных исследований характеризуется установлением все более интегрированных связей междисциплинарного характера. Другими словами, отдельные науки все более «проникают» в области исследования смежных наук, используя полученные ими результаты или разработанные ими методы исследований для достижения своих целей.

Таблица 3.1

Фундаментальные положения методологии деятельности

\begin{tabular}{|c|c|}
\hline Положение & Содержание \\
\hline 1. Функция методологии & Обеспечение универсума человеческой деятельности \\
\hline $\begin{array}{l}\text { 2. Продукт реализации } \\
\text { функции методологии }\end{array}$ & $\begin{array}{l}\text { Не собственно знания, а конструкции, проекты, нормы и } \\
\text { методические предписания }\end{array}$ \\
\hline $\begin{array}{l}\text { 3. Критерий оценки } \\
\text { продукта }\end{array}$ & Проверка на реализуемость, а не на истинность \\
\hline $\begin{array}{l}\text { 4. Соотношение науч- } \\
\text { ного знания и продукта }\end{array}$ & Научное знание рефлексивно включено в продукт \\
\hline $\begin{array}{l}\text { 5. Соотношение методо- } \\
\text { логической деятельности и } \\
\text { методологического } \\
\text { мышления }\end{array}$ & $\begin{array}{l}\text { Неразрывность, позволяющая реализовать в единстве } \\
\text { методологическое исследование и познание с продуктом } \\
\text { методологии }\end{array}$ \\
\hline 6. Объект методологии & $\begin{array}{l}\text { Рассматривается как гетерархический (в методологии } \\
\text { деятельности иерархический), представляющий собой } \\
\text { связку двух объектов: внутрь исходного для методологии } \\
\text { объекта деятельности и мышления вставлен другой объект - } \\
\text { объект конкретной деятельности }\end{array}$ \\
\hline $\begin{array}{l}\text { 7. Свойство объекта } \\
\text { методологии }\end{array}$ & $\begin{array}{l}\text { Гетерархическое представление } \\
\text { мультиплицирования }\end{array}$ \\
\hline 8. Связующее звено & $\begin{array}{l}\text { Эту роль выполняют онтологические } \\
\text { методологической деятельности, связывающие } \\
\text { разные онтологические схемы, объясняющие конкретную } \\
\text { деятельность }\end{array}$ \\
\hline
\end{tabular}

Поэтому системное представление методологии взаимодействия субъектов предпринимательства предполагает учет частных методологий, свойственных

${ }^{1}$ Блауберг И. В., Юдин Э. Г. Становление и сущность системного подхода. М.: Наука, 1973; Емельянов С. В., Наппельбаум Э. Л. Основные принципы системного анализа // Проблемы научной организации управления социалистической промышленностью. М.: Экономика, 1974; Системы, целенаправленность, рефлексия // Системные исследования. Методологические проблемы: ежегодник, 1981. М.: Наука, 1981; МильманB.Э. Побудительные тенденции в структуре деятельности // Вопросы психологии. 1982. № 3. Цель как способ проектирования деятельности Системные исследования. Методологические проблемы: ежегодник. 1986. М.: Наука, 1987; Щедровиикий Г. П. К характеристике наиболее абстрактных направлений методологии структурно-системных исследований // Проблемы исследования систем и структур. М.: АН СССР, 1965. Проблемы методологии системного исследования. М.: Знание, 1964; Юдин Э. Г. Деятельность и системность // Системные исследования: ежегодник, 1976. М.: Наука, 1976; Системный подход и принципы деятельности. Методологические проблемы современной науки. М.: Наука, 1978. 
отдельным смежным наукам, таким как менеджмент (управление) и экономическая теория. Но с другой стороны, очевидно, что ограничение только частными методологическими разработками не может дать полного системного представления о методологии. Следовательно, необходимо органично включить в его системное представление методологические составляющие, применимые для всех направлений научно-практической деятельности ${ }^{1}$.

Представленные в табл. 3.1 фундаментальные положения методологии деятельности для своей реализации требуют определения тех методологических принципов, опираясь на которые в дальнейшем исследовании становится возможным рассмотрение связки «объект-предмет» конкретной деятельности, а именно взаимодействия субъектов предпринимательства.

Исследователи в области методологии деятельности подчеркивают, что одним из основополагающих методологических принципов любого научного исследования, посвященного развитию частной методологии, является принцип множественности представлений и знаний, относимых к одному объекту.

Если появление другого философского знания об одном и том же объекте в логике объективно требует ответа на вопрос, какое же из них истинно, то в методологии деятельности аналогичная ситуация не может быть предметом выяснения истины, как не могут быть проверены на верность и истинность совершенно различные знания. Разница рассматривается как объективный момент деятельностной ситуации.

Собственно формирование конкретного представления о связке «объектпредмет» связано с проявлением логики методологической рефлексии. То есть реализация принципа множественности не отделима от следующего методологического принципа методологии деятельности - принциипа рефлексивности. Не называя принципа рефлексивности, Ф. А. Хайек указывает на существенную важность его присутствия в научных исследованиях. «...Большую часть знания дает нам не непосредственный опыт и не наблюдение, а непрерывный процесс «пропускания через себя усваиваемых традиций...». Принцип рефлексивности позволяет и помогает своеобразным образом реконструировать принятый к исследованию объект с учетом множественности представлений о нем. Объект познания методологически преобразуется через призму рефлексивности в предмет познания, который не может быть полностью сведен к объекту, так как является его частью. Движение и развитие объекта обусловливает движение и развитие предмета. Вместе с тем последний развивается с развитием логики рефлексии. Один из авторов методологии деятельности Г. П. Щедровицкий подчеркивает: «Понимание чужой мысли вызывает обычно большие затруднения, буквально мучения стремящегося понять сознания, и создает многочисленные расхождения в субъективных ее истолкованиях» ${ }^{2}$. Это еще раз доказывает необходимость включения в систему таких принципов, как множественность и рефлексивность.

Методологически объект - это направление познавательной активности. «Натуральный», по определению Г. П. Щедровицкого, природный объект не познаваем в широком смысле из-за своей многогранности. Можно только, более

${ }^{1}$ Асаул Н. А. Методические принципы институциональных взаимодействий субъектов рынка как открытых «живых» систем в концепции информационного общества. М.; СПб.: «Вольное экономическое общество России», 2004.

${ }^{2}$ Щедровиикий Г. П. Схема мыследеятельности - системно-структурное строение, смысл и содержание // Системные исследования: ежегодник, 1986. М.: Наука, 1986 
досконально изучив его какую-то сторону, приблизиться в какой-либо мере к ее объективному представлению. Поэтому естественно-научное представление об объекте в рассматриваемой методологии заменяется на деятельностное. «Опираться же такая замена должна на совершенно новую логику мышления, с ее помощью исследователь сможет объединить комплексные структуры знаний в единое целое. А это в свою очередь требует выделения определенной области методологически рефлексивных знаний» ${ }^{1}$.

Понятие деятельности говорит о том (табл. 3.2), что объект -это сложная композиция, включающая как рефлексивные знания о самой методологии, так и знания о собственно объектной деятельности, то есть объект познается как бы в двойственном представлении. Отсюда вытекает необходимость введения принципа двойственности.

Таблица 3.2 .

Признаки деятельности и их содержание

\begin{tabular}{|l|l|l|}
\hline \multicolumn{1}{|c|}{ Признак деятельности } & \multicolumn{1}{|c|}{ Содержание } \\
\hline 1. Объектность & Объектно-ориентированный характер \\
\hline 2. Опосредованность & $\begin{array}{l}\text { Существует только через отношение субъекта и } \\
\text { объекта }\end{array}$ \\
\hline $\begin{array}{l}\text { 3. Единство внутренней и } \\
\text { внешней сторон }\end{array}$ & $\begin{array}{l}\text { Внешние преобразования находят отражение во } \\
\text { внутреннем содержании субъекта и наоборот }\end{array}$ \\
\hline $\begin{array}{l}\text { 4. Определенная иерархическая } \\
\text { структура }\end{array}$ & $\begin{array}{l}\text { Цели деятельности предопределяют результат через } \\
\text { действия }\end{array}$ \\
\hline
\end{tabular}

В соответствии с принципом двойственности методология деятельности есть симбиоз разных типов знаний и соответствующих им типов мышления - новая более сложная структура с более сложными взаимосвязями, построенная на сочетании и соединении естественнонаучных, методологических и практико-методических знаний. Но, несмотря на разнородность знаний, согласно требованиям принципов множественности, рефлексивности и двойственности, она должна быть не только единой, целостной, отражающей объединение методологических представлений, но и целенаправленной, подчиняющейся целям практической деятельности. Последнее обусловлено тем, что собственно создание методологии не может определяться как самоцель, необходимость такого рода исследований, прежде всего, диктуется проблемами научно-теоретического и практического характера. Следовательно, можно сформулировать четвертый методологический принцип - принцип целостности.

Неотъемлемой характеристикой методологии деятельности является динамизм. Изменения в парадигмальных представлениях объективно требуют изменений и в теории, и в методах исследования, и в методических положениях. И, наоборот, неспособность методических рекомендаций дать решение проблемы может повлечь за собой полный пересмотр методологии, вплоть до ее парадигмальных основ. Поэтому можно определить следующий пятый методологический принцип методологии деятельности - принщип взаимообусловленности ${ }^{2}$.

Методология деятельности привлекает все больше внимания как зарубежных

${ }^{1}$ Танеи перемен: новые проблемы самообучающихся организаций / П. М. Сенге и др. М.: ЗАО «Олимп-Бизнес», 2003.

${ }^{2}$ Асаул Н.А. Методические принципы институциональных взаимодействий... 
ученых, так и отечественных ${ }^{1}$. Растущая популярность этой теории объясняется базисным характером методологических принципов.

Термин «взаимодействие субъектов предпринимательства» означает их «взаимное действие» или «обмен действиями». В более сложной форме суть термина сводится к обмену деятельностями между субъектами предпринимательства. Таким образом, рассматривая проблему взаимодействия субъектов предпринимательства в рыночной сети, неизбежно приходим к проблеме связи деятельностей отдельных субъектов предпринимательства. Анализ этой проблемы в контексте деятельности осуществлялся Н. А. Асаулом.

Для деятельности свойственны признаки, которые образуют ткань рыночного взаимодействия ${ }^{2}$.

Рассмотрим содержание табл. 3.2 более подробно. По первому признаку можно сказать, что реальная действительность объективна в широком смысле слова. Ее существование не зависит как от индивидуального сознания, так и от отношения индивида к ней.

Реальность состоит из неких объектов, обладающих природными, социальными, культурными и иного рода свойствами. Деятельность же всегда связана с субъектно-объектными отношениями, то есть объект является неотъемлемой частью деятельности, без объекта деятельности и самой деятельности не может существовать. Следовательно, деятельность всегда носит объектноориентированный характер.

Второй признак - опосредованность деятельности означает существование ее или ее определение через отношение к субъекту и объекту деятельности. Другими словами, свойства деятельности раскрываются только во взаимодействии, только через реальные взаимодействия деятельность может быть тем, что она есть, может быть определена конкретной деятельностью. Взаимоотношения между субъектами в процессе взаимодействия (или обмена деятельностями) опосредуются знаками, символами, артефактами.

По третьему признаку теория деятельности подчеркивает, что деятельность людей является инструментальной. С одной стороны, она выступает как внешний инструмент преобразования окружающей среды, а с другой, - как внутренний инструмент самопреобразования субъекта. Внутренняя деятельность планирует внешнюю; она возникает на основе внешней и через нее реализуется. Разделение труда влечет за собой выделение практической и теоретической форм деятельности. В зависимости от разнообразия потребностей складывается и многообразие конкретных видов деятельности, каждый из которых включает элементы и внешней, и внутренней, и теоретической и практической деятельности. И указанные выше инструменты опосредования деятельности создаются и трансформируются в процессе развития деятельности и, закрепляясь внутренне, образуют определенную культуру. Использование этих инструментов обеспечивает накопление и передачу социального знания в процессе взаимодействия, что влияет на характер поведения субъектов.

Четвертый признак - иерархическая структура деятельности (рис. 3.1). Между

${ }^{1}$ Климов СМ. Интеллектуальные ресурсы общества. СПб.: ИВЭСЭП, Знание, 2002; Модели и методы управления персоналом / под ред. Е. Б. Моргунова. М.: ЗАО «Бизнес-Синтез», 2001; Bellinger G. Managing Individual and Organizational Knowledge. 1997. URL: http: // www.outsights.com $/ \mathrm{kmgmt} / \mathrm{kmgmt} . \mathrm{html}$

2 Лэйхифф Дж. М, Пенроуз Дж. М. Бизнес-коммуникации. Стратегии и навыки / пер. с англ. СПб.: Питер, 2001. 
объектом и потребностью существует связь, носящая мотивационный характер. Если потребность не удовлетворена или удовлетворена не полностью, то степень этого несоответствия стимулирует объект к обусловленной мотивом деятельности (1 уровень). Мотив в свою очередь приводит к предварительной формулировке цели, которая обусловливает планирование конкретных действий (2 уровень). Достижение цели зависит от условий, они же определяют и специфику операций (3 уровень).

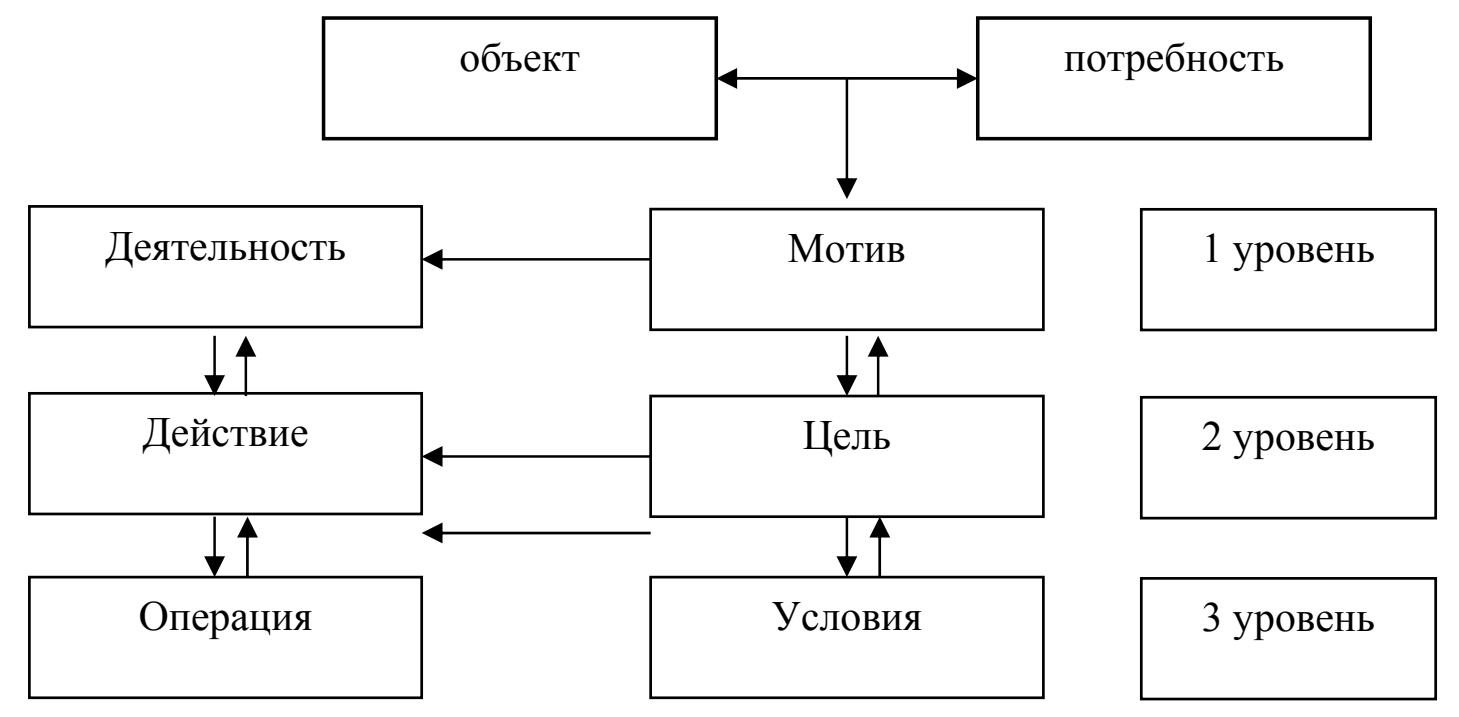

Рис. 3.1. Иерархическая структура деятельности 138

Далее уточнение содержания иерархических уровней деятельности происходит в обратном порядке.

Можно рассмотреть содержание рис. 3.1 с иных позиций. Первичными компонентами деятельности являются действия и операции. Деятельность формируется из целенаправленных действий, которые в своей совокупности обеспечивают реализацию мотива деятельности. Одна и та же деятельность может быть направлена на реализацию различных целей. Действия являются осознанными. Планы действий, используемые на этом уровне, являются осознанными (осознанные знания).

Действия осуществляются через автоматические в интеллектуальном смысле слова операции. Операции не имеют собственных целей, они формируют и корректируют содержание действия в соответствии с конкретной ситуацией, в которой оно осуществляется. Именно в операциях осуществляется так называемое неявное знание.

Представленные на рис. 3.1 компоненты деятельности могут динамически изменяться. Осознание мотивов деятельности трансформирует ее в действие, то есть происходит «проецирование» мотива на цель. Действие, в свою очередь, может преобразовываться в деятельность через интернализацию, то есть переход к новому циклу моделирования действительности с учетом фактических условий и результатов. Аналогичным образом действия могут приобретать статус операций и наоборот.

Важным выводом из анализа рис. 3.1 является не только иерархическая структура деятельности субъектов предпринимательства, но и то, что в ее формировании и преобразовании участвует такая категория, как знание, в данном 
случае присутствующая в явной и неявной формах.

При разработке методики классифицирования деятельности активно использованы положения системомыследеятельностной методологии (СМД). Это объясняется тем, что СМД - единственная методология, занимающаяся исследованием феномена деятельности с предельно общих позиций (а не с частных). СМД зародилась в 50-х гг. ХХ-го столетия. Основоположниками методологии являются А. Зиновьев, Б. Грущин, М. Мамардашвили и Г. Щедровицкий.

Одной из базовых категорий СМД является категория акта деятельности, основные элементы которого схематически представлены на рис. $3.2^{1}$.

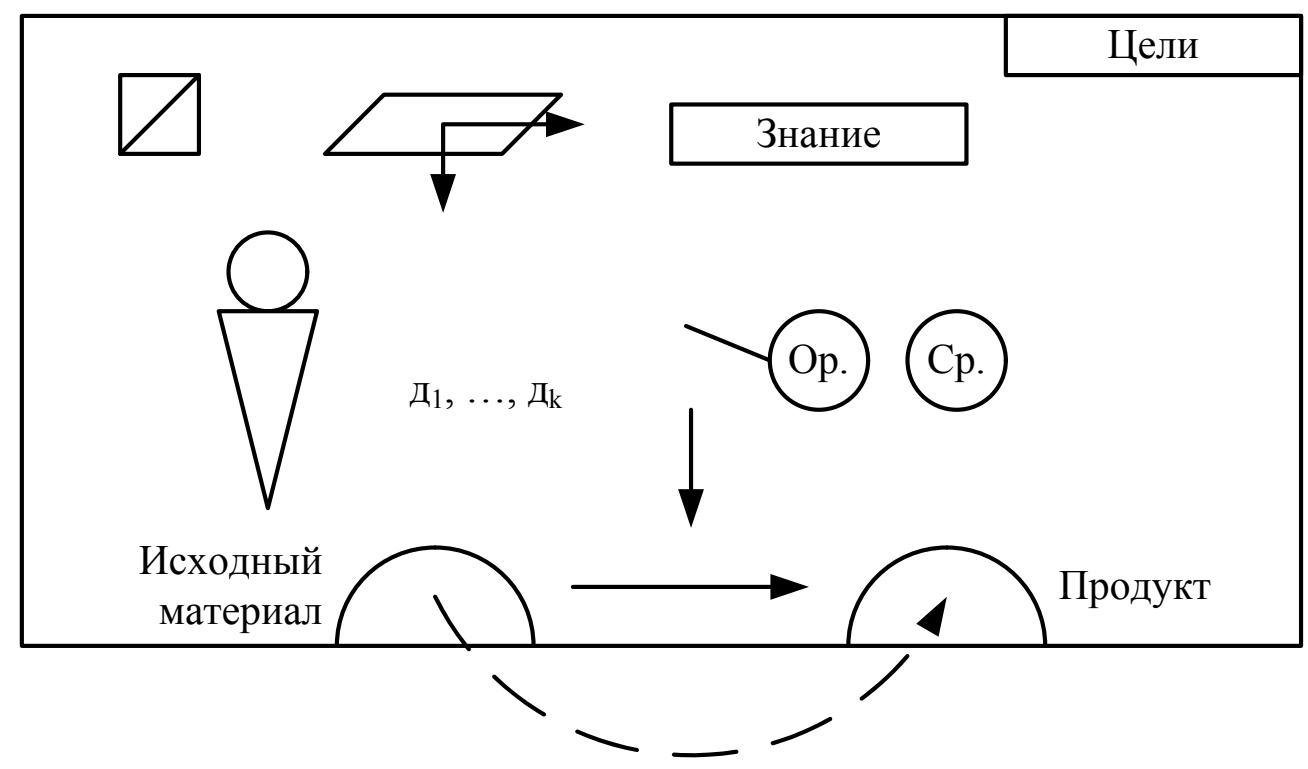

Рисунок 3.2 Схема акта деятельности ${ }^{2}$

Рассмотрим изображенные на рисунке элементы акта деятельности (схематические изображения - слева-направо, сверху-вниз): способности и интериоризированные средства, табло сознания (с определенными интенциями), знания, целевые установки, субъект деятельности, набор действий или операций, используемые орудия и средства, исходный материал, продукт (на выходе акта деятельности). Любая деятельность состоит из множества сложным образом связанных друг с другом элементарных актов деятельности. С точки зрения процесса полный цикл мыследеятельности включает в себя следующие этапы:

коммуникация - обмен информацией в процессе взаимодействия с другим человеком;

замещзение - «опредметизация» объекта мыследействия;

чистое мышиление - мыслительные операции с предметом мышления; выработка концепции (мыслительной конструкции) и работа с ней;

отнесение - отнесение результатов мышления к объекту, разработка плана

${ }^{1}$ Путеводитель по методологии Организации, Руководства и Управления: хрестоматия по работам Г. П. Щедровицкого / сост. А. П. Зинченко. М.: Дело, 2003.

2 . Путеводитель по методологии Организации, Руководства и Управления: Хрестоматия по работам Г.П. Щедровицкого /сост. А.П. Зинченко. М.: Дело, 2003. - 160 с. 
действий на основе мыслительной концепции;

действие - осуществление действий с объектом действия;

рефлексия - чувствительно осознание полученных результатов.

После реализации всех этапов цикл повторяется. Действие -реализация акта деятельности. Когда субъект осуществляет действие, он не противопоставляет себя объекту деятельности, не осмысливает социальную структуру, в которую он включен. В случае, если после реализации действия достигнут необходимого результата, осуществляются следующие акты мыследеятельности (рис. 3.3); если же необходимый результат не достигнут или следующие акты действия требуют определенной мыслительной работы, осуществляются рефлексия и мышление. Если необходимо получение информации от других людей, субъект коммуницирует с ними.

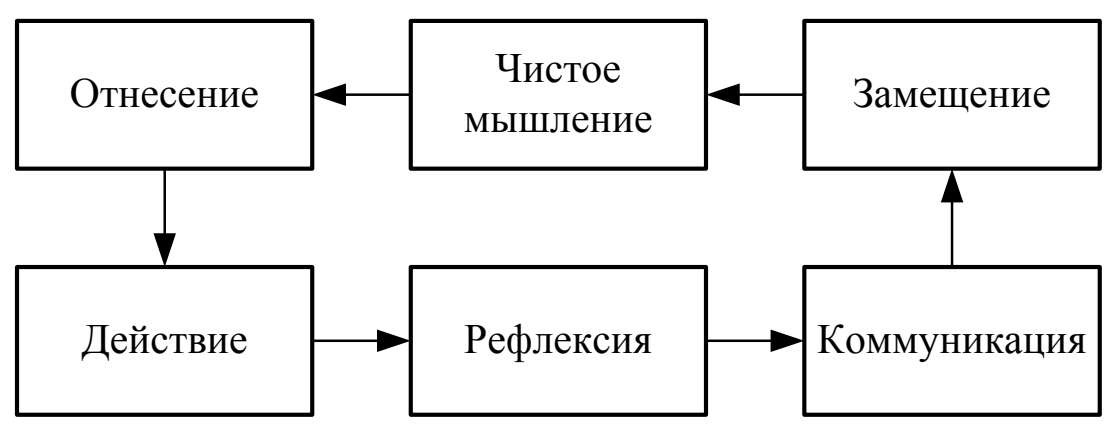

Рис. 3.3. Полный цикл мыследеятельности

Рефлексия- это чувственное, эмоциональное осознание, осмысление ситуации и себя в ней на основе имеющегося опыта (интеллектуальных моделей). Выделяют ретроспективную рефлексию (осмысление прошлого) и перспективную (попытка осмысления будущего). Считается, что благодаря рефлексии субъект накапливает опыт. В результате рефлексии субъект выделяет объект для анализа на одном из следующих этапов.

Мышление - этот этап состоит из идеализации (или замещения), собственно чистого мышления и отнесения (или проектирования). Идеализация - это «опредмечивание» выделенного в результате рефлексии объекта, то есть подбор для объекта определенного схематизма (выбор предмета из предметной области), который выражает связь знаний субъекта с объектом анализа (рис. 3.4).

Считается, что между «миром реальных объектов» и «миром идеальных объектов» находится «мир смыслов (находящихся в потенции)», из которых субъект посредством понимания на основе имеющегося опыта «раскрывает» конкретный смысл (то есть создает на доске или планшете своего сознания предмет для дальнейшей мыслительной работы с ним). Таким образом, задача идеализации создание идеальной знаковой модели реального объекта (предмета анализа).

Чистое мышление. В зависимости от того, какая знаковая форма использовалась для создания модели объекта, в процессе мышления используется тот или иной «язык» для нахождения искомого решения. Язык мышления представляет собой определенный набор правил (логических - математика явления и онтологических - физика явления) действий с предметами, относящимися к 
соответствующему классу. Работа по решению любой задачи состоит в том, чтобы «найти такой язык мышления, используя средства которого, можно ясно увидеть решение». На выходе данного этапа получаем решение, закодированное на соответствующем языке мышления. Для того, чтобы соотнести это решение с реальным объектом, реализуются связи отнесения.

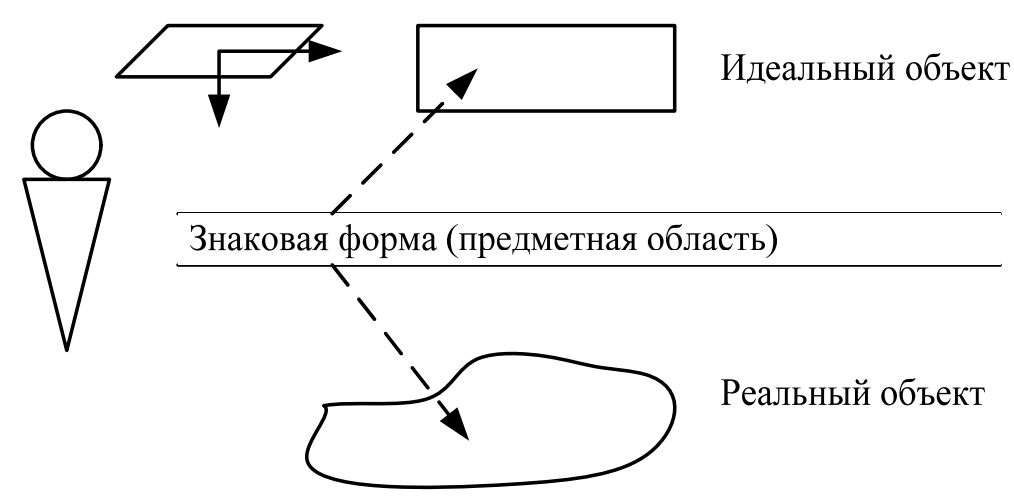

Рисунок 3.4 - Связи замещения и отнесения между предметом и объектом анализа ${ }^{1}$.

Описанная модель мыследеятельности (рис. 3.5) характеризует акт мыследеятельности в своей полной форме, что встречается на практике достаточно редко. Объясняется это широким использованием концепции разделения труда Адама Смита. В современных предпринимательских структурах задачи распределяются таким образом, что субъект вынужден специализироваться на отдельных этапах общего процесса, редуцируя при этом выполнение остальных этапов своего процесса мыследеятельности. Таким образом, модель мыследеятельности изоморфна: весь процесс функционирования предпринимательской структуры можно представить в виде процесса мыследеятельности, а деятельность одних сотрудников -как реализацию отдельных составляющих этой «мыследеятельности» предпринимательского формирования. Это значит, что можно выделить субъектов, специализирующихся на замещении, на чистом мышлении, на коммуникации, на рефлексии и т. д.

Результаты опроса 62-х представителей различных компаний г. Братска, а также результаты теоретического исследования данного вопроса позволяют проследить, как распределяются роли в «мыследеятельности» организации среди её различных подразделений. Это соответствует схеме, представленной на рисунке (естественно, с поправкой на особенности той или иной предпринимательской модели). Список вопросов, задаваемых респондентам, приведен в приложении.

1 . Путеводитель по методологии Организации, Руководства и Управления: Хрестоматия по работам Г.П. Щедровицкого /сост. А.П. Зинченко. М.: Дело, 2003. - 160 с. 


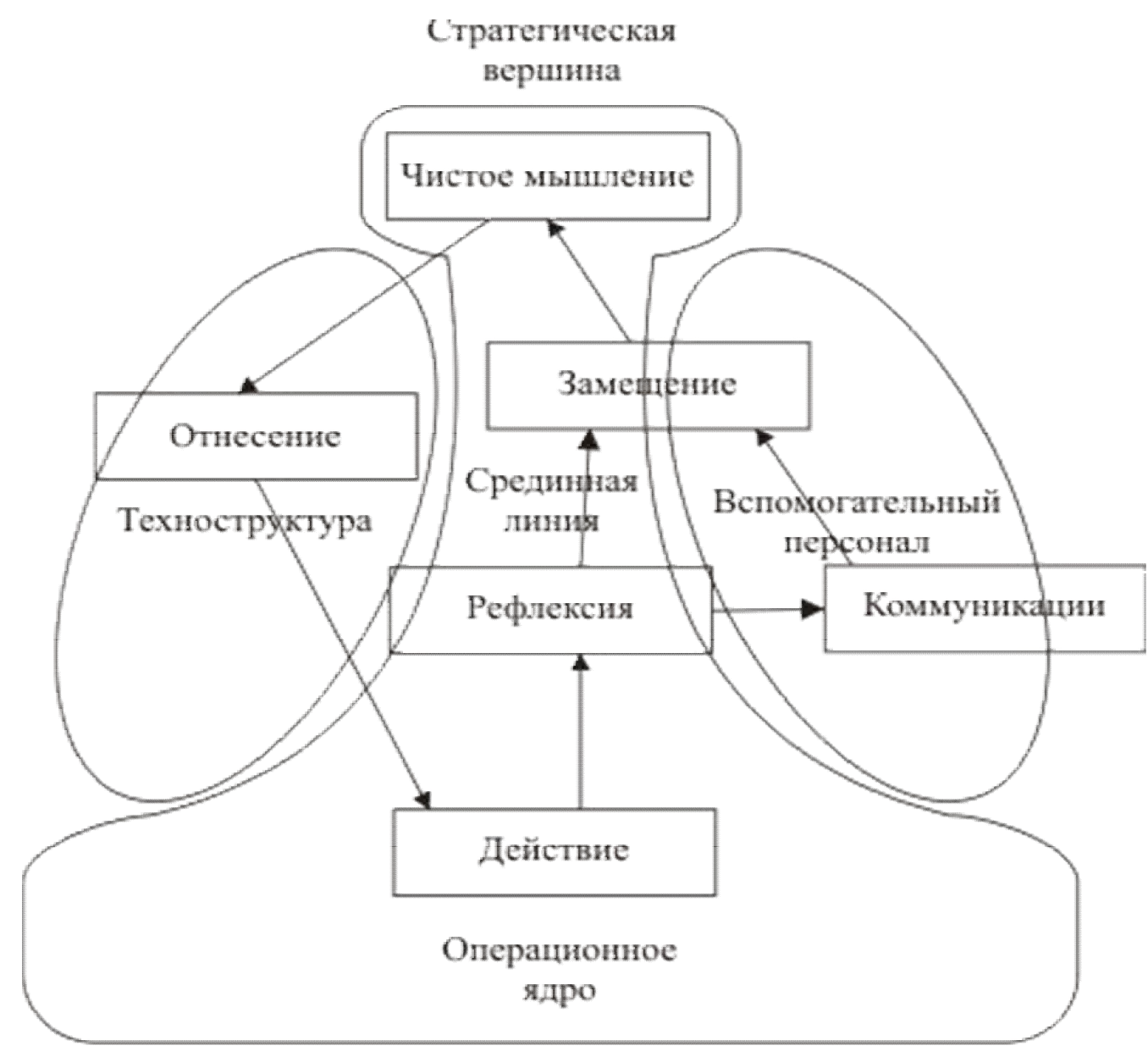

Рис. 3.5. Модель распределения задач мыследеятельности между подразделениями предпринимательской структуры

Список опрашиваемых формировался посредством случайной выборки из перечня организаций города, но в него вошли только те компании, у которых четко прослеживается используемая предпринимательская модель. Данные, представленные в табл. 3.3, характеризуют мыследеятельность механистической бюрократии. В случае анализа компаний с другими предпринимательскими моделями наблюдаются иные зависимости:

1. Инновационная модель, когда из-за отсутствия техноструктуры и срединой линии, рефлексия, замещение, чистое мышление и отнесение сосредоточены в руках стратегической вершины.

2. Профессиональная модель, при которой из-за особой специфики деятельности практически все составляющие мыследеятельности реализуются представителями операционного ядра. Но эти представители обычно разобщены (вследствие высокой специализации и высокого профессионализма сотрудников), поэтому процесс мыследеятельности реализуется фрагментировано.

3. В адхократиях ключевую роль играют рабочие созвездия, состав которых изменяется от проекта к проекту, что влечет за собой динамичное перераспределение задач по реализации отдельных составляющих мыследеятельности компании. 
Роль подразделений организации в общем процессе мыследеятельности (механистическая бюрократия)

\begin{tabular}{|c|c|c|}
\hline $\begin{array}{l}\text { Составляющая } \\
\text { мыследея- } \\
\text { тельности }\end{array}$ & $\begin{array}{l}\text { «Ответственная» } \\
\text { часть организации }\end{array}$ & $\begin{array}{l}\text { Примеры действий, соответствующих } \\
\text { составляющей мыследеятельности }\end{array}$ \\
\hline 1. Действие & Операционное ядро & Исполнение деятельности \\
\hline 2. Рефлексия & \begin{tabular}{|l|} 
Срединная \\
стратегическая \\
вершина
\end{tabular} & $\begin{array}{llr}\text { Контроль над } & \text { исполнением; } & \text { осмысление } \\
\text { достигнутых } & \text { результатов; } & \text { выработка } \\
\text { «текущего» решения проблемы } & \end{array}$ \\
\hline 3. Замещение & $\begin{array}{l}\text { Срединная линия, } \\
\text { вспомогательный } \\
\text { персонал }\end{array}$ & $\begin{array}{l}\text { Определение } \quad \text { характера } \\
\text { «опредметизация» проблемы }\end{array}$ \\
\hline $\begin{array}{l}4 . \quad \text { Чистое } \\
\text { мышление }\end{array}$ & $\begin{array}{l}\text { Используется слабо. } \\
\text { Стратегическая } \\
\text { вершина }\end{array}$ & $\begin{array}{lr}\text { Разработка } & \text { стратегии; } \\
\text { принципиального } & \text { решения } \\
\text { разработка инновационной идеи }\end{array}$ \\
\hline 5. Отнесение & $\begin{array}{l}\text { Техноструктура, } \\
\text { вспомогательный } \\
\text { персонал }\end{array}$ & $\begin{array}{l}\text { Разработка и внедрение регламентов, контроль } \\
\text { соблюдения; разработка программы действий; } \\
\text { планирование реализации нового проекта }\end{array}$ \\
\hline
\end{tabular}

Существуют закономерности, касающиеся деятельности отдельных сотрудников. Во-первых, анализ показывает, что весь процесс мыследеятельности предпринимательской структуры распределяется среди ее сотрудников, каждый из которых имеет один из типов возможных специализаций: три базовых специализации и три дополнительных. Базовые специализации: на действии (преобразовании вещи), на мышлении (преобразование мыслительных конструкций), на коммуникации (обмен информацией). Сотрудник, имеющий одну из этих специализаций, развивает у себя один из типов профессионализма:

технический профессионализм - умение осуществлять преобразования вещей такие требования характерны для исполнителей (операционное ядро);

социальный профессионализм - умение взаимодействовать с людьми требования характерны для должностей, где социальные взаимодействия играют большую роль;

концептуальный профессионализм - умение оперировать ментальными моделями - сложнее других поддается развитию.

Дополнительные специализации - на замещении, на отнесении или на рефлексии - требуют развития всех типов профессионализма, но в разной степени. Данный вывод подтверждается анализом большого количества должностных инструкций действующих организаций.

Во-вторых, на распределение ответственности за реализацию отдельных составляющих процесса мыследеятельности оказывают влияние такие характеристики деятельности, как стабильность содержания выполняемой работы и уровень ее сложности (высокие значения обеих характеристик значительно увеличивают издержки коммуникации и координации, поэтому оптимальным является предоставление сотруднику, действующему в таких условиях, большей степени свободы). В общем случае реализация одной составляющей мыследеятельности предъявляет низкие требования к соответствующему типу 
профессионализма; реализация всех составляющих требует высокого уровня профессионализма.

Отдельного анализа заслуживает влияние формирования системы создания и управления организационными знаниями предпринимательской структуры на уровень ее конкурентоспособности, а также конкурентоспособности системы управления предпринимательской структуры.

Конкурентоспособность - это комплексная характеристика деятельности предпринимательского формирования, связанная как с характеристикой эффективности самой предпринимательской структуры (ресурсно-ориентированный подход), так и с анализом положения (или позиции) предпринимательского формирования во внешней среде (на рынке, так называемый рыночно-ориентированный подход). Конкурентоспособность предпринимательской структуры включает в себя конкурентоспособность ее продукции (услуги), а также включает в себя эффективность практически всех внутренних процессов, так как эти процессы прямо или опосредованно, в большей или меньшей степени отражаются на положении предпринимательской структуры на рынке.

Таким образом, конкурентоспособность - это комплексная относительная характеристика деятельности предпринимательской структуры, отражающая ее способность превосходить своих конкурентов в процессе удовлетворения требований покупателей и клиентов.

Известны следующие методики и подходы для оценки уровня конкурентоспособности предпринимательского формирования ${ }^{1}$ :

сведение конкурентоспособности предпринимательской структуры к конкурентоспособности продукции;

расчет интегральной оценки, учитывающей степень удовлетворения потребностей потребителей, а также уровень эффективности предприятия;

матричные методы оценки конкурентоспособности;

многомерная концепция конкурентоспособности, включающая в себя три группы показателей, измеряющие уровень конкурентного преимущества, адаптивности предпринимательской структуры, а также результаты экономической деятельности;

теория международного разделения труда (в основе конкурентоспособности сравнительные преимущества);

теория равновесия фирмы и рынка и факторов производства;

метод построения многоугольных профилей;

теория эффективной конкуренции.

Теория эффективной конкуренции наиболее подходит к решению задач настоящего исследования, так как обладает комплексностью. Сущность ее в том, что она включает два основных подхода: структурный и функциональный. Структурный подход - это акцентирование внимания исследователя на внешнем аспекте конкурентоспособности, то есть на том, что конкурентоспособность конкретной предпринимательской структуры во многом зависит от рыночных сил конкуренции (здесь исследуются степень концентрации капитала и производства, а также барьеры входа в отрасль). Функциональный подход указывает на активную позицию в повышении уровня конкурентоспособности предпринимательской структуры. Здесь

${ }^{1}$ Оиенка конкурентных позиций субъектов предпринимательской деятельности / А. Н. Асаул и др.; под ред. А. Н. Асаула. СПб. АНО ИПЭВ, 2007.; Катькало В. Организационные факторы конкурентных преимуществ фирм. URL: http://bigc.ru/publications/other/km/ 
предлагается исследовать показатели эффективности производственно-сбытовой деятельности, интенсивность использования основного и оборотного капитала, а также финансовые показатели. Кроме того, некоторыми учеными предлагается дополнить этот список показателями конкурентоспособности продукции.

В практике широко используется показатель уровня конкурентоспособности, рассчитываемый следующим образом:

$$
K_{\text {Total }}=I_{\mathrm{Pr}} \cdot I_{\text {Eff }}
$$

где $K_{\text {Total }}$ - комплексный показатель уровня конкурентоспособности; $I_{\mathrm{Pr}}$ индекс конкурентоспособности продукции; $I_{E f f}$ - индекс относительной эффективности предпринимательской структуры.

Для диверсифицированной предпринимательской структуры индекс конкурентоспособности продукции рассчитывается следующим образом ${ }^{1}$ :

$$
I_{\mathrm{Pr}}=\sum_{i=1}^{m} \beta_{i} \frac{n_{i}}{n_{i \sigma}} \cdot \frac{K_{i}}{K_{i \sigma}} \cdot \frac{3_{i \sigma}}{3_{i}}
$$

где: $m$ - число видов производимого товара;

$n_{i}, n_{i \sigma}$ - количество товара вида, предлагаемого на рынке конкурирующими сторонами;

$\beta_{i}$ - коэффициент значимости $i$-го товара в конкуренции на рынке;

$K_{i}, K_{i \sigma}$ - комплексные показатели качества конкурирующих товаров - данного и базового;

$3_{i \sigma}, 3_{i}$ - совокупные затраты потребителя.

В качестве показателей эффективности предпринимательской структуры могут использоваться рентабельность продукции, уровень производительности труда, фондоотдача и другие показатели:

$$
I_{\ni}=\sum_{j=1}^{k} \gamma_{j} E_{j} / E_{j \sigma}
$$

где: $k$ - количество показателей эффективности;

$\gamma_{j}$ - коэффициент значимости показателя эффективности;

$E_{j}, E_{j \sigma}$ - частные показатели эффективности предпринимательской структуры и ее конкурента.

Под конкурентоспособностью системы управления предпринимательской структурой принято понимать уровень качества принимаемых решений, реализация которых в конечном итоге приводит к определенному уровню

1 Адлер Ю., Черных E. Управление знаниями: новые акценты поиска источников конкурентных преимуществ. URL: http://bigc.ru/publications/other/km/ 
конкурентоспособности продукции и конкурентоспособности предпринимательской структуры на рынке (функциональный подход). Более того, высокий уровень конкурентоспособности системы управления предпринимательского формирования может впоследствии обеспечить перераспределение рыночной власти на рынке (структурный подход).

Формирование в рамках предпринимательской структуры системы создания и управления организационными знаниями упорядочивает работу с информацией и знаниями, обеспечивает быстрый доступ к ключевым знаниям и информации, что приводит к повышению качества принимаемых решений, скорости их принятия, а, значит, увеличивается конкурентоспособность системы управления предпринимательской структурой. Кроме того, упорядочивание информационных потоков и работы со знанием приводит к повышенной мотивации сотрудников и повышению качества исполнения, то есть оказывает не только опосредованное воздействие, но и напрямую повышает конкурентоспособность продукции и предпринимательского формирования.

\section{2. КЛАССИФИКАЦИЯ ПРЕДПРИНИМАТЕЛЬСКИХ МОДЕЛЕЙ ХОЗЯЙСТВОВАНИЯ ДЛЯ ОПРЕДЕЛЕНИЯ ПОДХОДА К СОЗДАНИЮ ССУО3}

Организационная модель хозяйствования - это некий комплексный базовый архетип организационной системы, который формируется под влиянием ситуационных факторов. Наиболее распространенным подходом к классификации и характеристике организационных моделей является структурный подход, который заключается в том, что под организационной моделью понимают тот или иной принципиальный тип организационной структуры (органическая модель, механистическая модель) $)^{1}$. Структура во многом определяет все остальные подсистемы организации, но она не является единственной организационной подсистемой. Есть и другие, не менее важные. В частности, речь идет об операционной подсистеме, культурной подсистеме, финансовой структуре и др. Все указанные подсистемы находятся в тесном взаимодействии друг с другом, которым и определяются значения показателей результативности и эффективности функционирования предприятия.

Для постановки в предпринимательской структуре системы создания и эффективного управления организационными знаниями требуется всесторонний более подробный (нежели структурный) анализ предпринимательской модели хозяйствования. Наиболее подходящим для решения этой задачи инструментом является модель «7S», разработанная Томасом Питерсом и Робертом Уотерманом ${ }^{2}$ (рис. 3.6).

Для того, чтобы выявить объективные зависимости между особенностями

${ }^{1}$ Виханский О.С, Наумов А. И. Менеджмент. М.: Гардарики, 2002.; Мескон М.Х., Альберт М,, Хедоури Ф. Основы менеджмента. М.: Дело, 2002.; О'Шоннесси Дж. Принципы организации управления фирмой. М.: 1999.

${ }^{2}$ Питере Т. Дж., Уотержан-жл. Р. Х. В поисках совершенства: уроки самых успешных компаний Америки. М.: Вильяме, 2005. 
используемой предпринимательской модели хозяйствования и оптимальным подходом к созданию и эффективному управлению организационными знаниями, необходима объемлющая классификация предпринимательских моделей хозяйствования (или, по другому, морфологических моделей, или организационных моделей). Но обзор литературы показывает, что на сегодняшний день в теориях организации и менеджмента разработаны только частные классификации предпринимательских моделей хозяйствования (структурные, операционные и др.). Используя указанную модель «7S», на основе изучения современной научной литературы, нами разработана собственная обобщенная (то есть характеризующая предпринимательскую модель всесторонне) классификация предпринимательских моделей хозяйствования. За основу этой классификации была взята классификация конфигураций Генри Минцберга ${ }^{1}$, которая была значительно дополнена и обобщена. Рассмотрим предложенную классификацию.

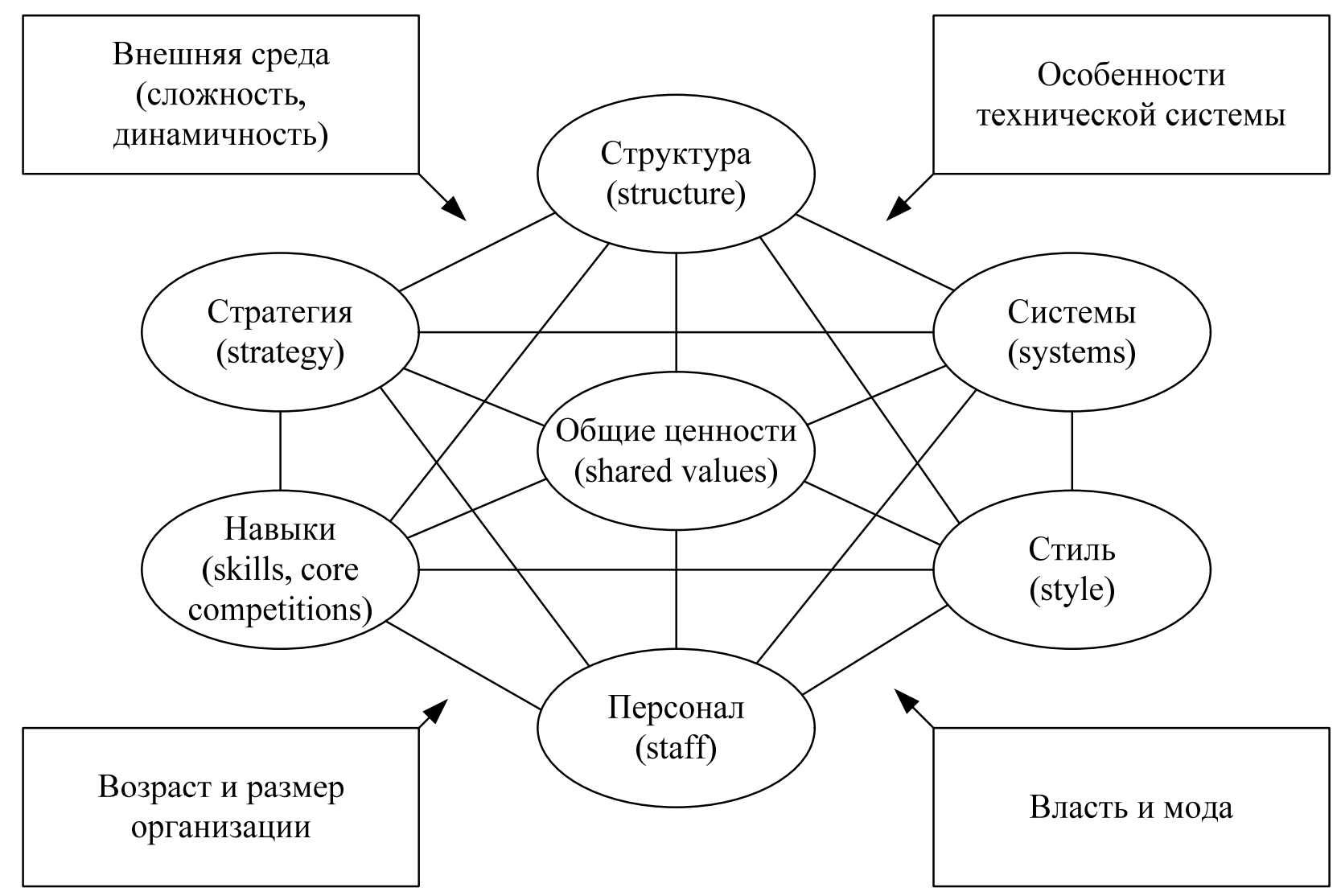

Рис. 3.6. Составляющие организационной модели по Т. Питерсу и Р. Уотерману

Г. Минцберг выделяет пять основных частей организации (рис. 3.7): операционное ядро, стратегическая вершина, срединная линия, техноструктура, аналитики и вспомогательный персонал. Операторы - это люди, выполняющие базовую работу по производству продуктов и предоставлению услуг. Они отвечают за реализацию следующих функций: снабжение основного рабочего потока необходимыми материалами и комплектующими, производство продукции или

${ }^{1}$ Минцберг Г. Структура в кулаке: создание эффективной организации / СПб.: Питер, 2004. 
предоставление услуги, сбыт и непосредственная поддержка основного рабочего потока.

Стратегическая вершина включает всех менеджеров высшего звена, в задачи которых входят прямой контроль, взаимодействие с внешними контрагентами и разработка стратегии развития предпринимательских структур. Срединная линия менеджмент средионным ядром и стратегической вершиной. Задачи срединной линии: участие в вертикальном информационном потоке (обобщение и передача), в принятии решений, распределении ресурсов, в разработке стратегии, взаимодействие с менеджерами других организационных единиц.

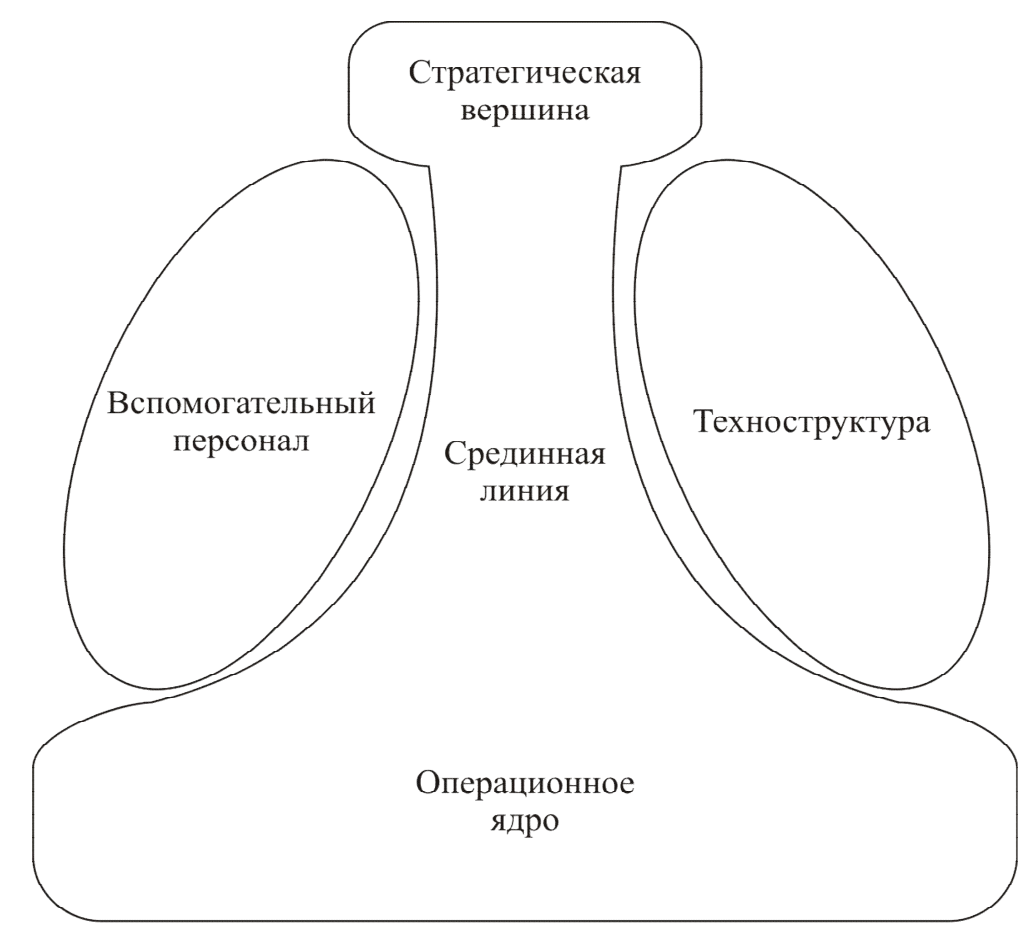

\section{Рисунок 3.7 - Части организации по Г. Минцбергу}

Иногда в составе организационных структур включают подразделение сотрудников-аналитиков. Они также выполняют административные функции, но иного рода (нередко их называют аппаратными или штабными). Аналитики образуют так называемую техноструктуру, расположенную вне иерархии линейных полномочий менеджеров. Получается административное разделение труда - между теми, кто занят в основной деятельности (или контролирует ее выполнение), и теми, кто еe стандартизирует. Задачи аналитиков: стандартизация процесса труда (нормирование труда), стандартизация выпуска (планирование и контроль), стандартизация навыков и квалификации (подбор и подготовка кадров).

Кроме того, структура может включать в свой состав штатные подразделения, занимающиеся «не стандартизацией, а дополнительным обслуживанием самой организации. Их сотрудников называют вспомогательным персоналом, а эту часть организации вспомогательной». Вспомогательная часть организации без техноструктуры в данной ситуации (и при данном уровне развития производства) не сможет обеспечить успешное развитие основного производственного процесса. Наличие же вспомогательных подразделений укрепляет жизнеспособность 
организации, но не являются критическим условием ее выживания. Примеры вспомогательных подразделений - столовая, собственная типография и др.

Координационные механизмы (по Г. Минцбергу) - это механизмы, обеспечивающие эффективное взаимодействие между сотрудниками при реализации процесса труда. Как правило, используются все механизмы координации, но обычно один из них (тот, который в наибольшей степени связан с координацией основного рабочего потока) - основной.

1. Взаимное согласование способствует координации труда благодаря простому процессу неформальных коммуникаций. При взаимном согласовании контроль над процессом труда осуществляется самими работниками. Поскольку здесь имеет место относительно простой механизм координации, взаимное согласование используется простейшими же организациями. Парадоксально, но этот механизм применяется и в более сложных условиях, когда не ясно, что и как следует делать - например, разработка нового технически сложного продукта.

2. Прямой контроль способствует координации, так как ответственность за работу других людей, определение заданий для них и наблюдение за их действиями возлагается на одного человека. По сути, один мозг координирует работу нескольких пар рук.

3. В более крупных организациях часто используют одну из форм стандартизации. Стандартизация означает предварительную спецификацию тех или иных аспектов процесса труда. Выделяют стандартизацию рабочих процессов, стандартизацию выпуска (или результатов труда) и стандартизацию навыков и знаний (квалификации).

Формализация поведения $u$ обучение потенциильных сотрудников. Формализация осуществляется для снижения вариативности поведения работников и увеличения его управляемости; для обеспечения постоянства и непредвзятого отношения к клиентам. Поведение может быть формализовано тремя основными способами:

• по должности, когда специфицируется непосредственно процесс труда (как в должностных инструкциях);

- по рабочему потоку, когда специфицируется содержание труда (как, например, в заказе на печатные работы);

- по правилам, когда разрабатываются общие спецификации, например, разнообразные, регламентирующие все от формы одежды до использования бланков, директивы (в так называемых руководствах по поведению).

Независимо от способа формализации - по должности, по рабочему потоку или по правилам - каждый из них регулирует поведение работника. Как выполнять рабочее задание, определяет человек, разрабатывающий спецификации, как правило, аналитик техноструктуры. Самые узкие из неквалифицированных видов работ одновременно самые простые, однообразные и поэтому в наибольшей степени подвержены формализации.

Обучение - ключевой проектный параметр для любой трудовой деятельности, которую можно назвать профессиональной. Обучаются, как правило, вне организации, в специализированных учреждениях.

Принципь группирования. Группирование по знаниям и навыкам должностные позиции объединяются в одну организационную единицу в соответствии с имеющимися у сотрудников специальными знаниями и навыками. Группирование по рабочим процессам и функциям - в группу входят сотрудники, 
выполняющие один и тот же вид деятельности либо одну и ту же функцию. Группирование по времени выполнения работы - например, посменное деление на группы. Группирование по выпуску - группы формируются по производимым ими продуктам или предоставляемым услугам. Группирование по клиентам группирование в зависимости от типов клиентов организации. Группирование по месту деятельности - формирование групп в соответствии с географией или по конкретному участку проведения операций.

Последние три принципа группирования формируют подразделения в соответствии с конечным результатом деятельности подразделения и носят общее название рыночного группирования. Первые два принципа относятся к функциональному группированию.

Системы планирования $и$ контроля. Выделяют два принципиально разных вида систем планирования и контроля: регулирование общих результатов и регулирование конкретных действий. Поскольку первый затрагивает в основном мониторинг итоговых показателей после их получения, его называют контролем над исполнением; второй, касающийся конкретных действий, - планированием действий.

Если контроль над исполнением - средство исключительно стандартизации выпуска, то планирование действий - поскольку оно определяет конкретные шаги - в некотором смысле напоминает такой параметр дизайна, как формализация поведения. Следовательно, контроль над исполнением используется обычно в рыночно ориентированных организационных единицах, так как результат деятельности такой единицы является цельным. Планирование действий же используется, в основном, в функционально ориентированных единицах, так как позволяет спланировать взаимодействие подразделений, результат деятельности которых не является завершенным (завершенность достигается их взаимодействием друг с другом, например: финансы + производство + сбыт). Планирование в этом случае касается только нерутинных действий, так как рутинные спланированы формализацией поведения.

Инструменты взаимодействия бывают четырех основных типов: связующие должностные позиции - вводятся, когда деятельность двух подразделений требует большого количества контактов, и эти контакты целесообразнее осуществлять, минуя вертикальные каналы взаимодействия. Данная должность не предполагает никакой формальной власти, но занимающий ее сотрудник часто приобретает большое влияние. Формально он может относиться к одному из отделов, но на практике часто взаимодействует с работниками другого отдела;

- специальные группы и постоянные комитеты создаются, когда в организации возникает потребность в периодических (комитеты) или апериодических (специальные группы) совещаниях;

- должность менеджера-интегратора вводится в случае необходимости более тщательной координации деятельности нескольких отделов. Менеджер-интегратор обладает некоторым объемом формальной власти над процессом принятия решений в отделах (правом либо санкционирования готовых решений, либо участия в разработке решений на ранних этапах, либо контроля процесса принятия решений);

- в матричной структуре используется одновременно и функциональный принцип группирования и рыночный. Внедрение этого инструмента взаимодействия требует наиболее глубокой перестройки структуры организации. Здесь нарушается принцип единоначалия -два руководителя делят властные полномочия в какой-то сфере и несут общую ответственность за результаты. Поэтому этим руководителям 
приходится неформально координировать свою деятельность.

Формы децентрализации. Децентрализация - распределение власти в организации. Выделяют два аспекта рассматриваемого понятия: то, куда передается власть, и то, какая власть туда передается:

1, a. Рассредоточение официальной власти вниз по цепочке полномочий. Чем больше власть отделена от стратегической вершины и распределена среди других менеджеров предприятия, тем выше уровень вертикальной децентрализации.

1, б. Горизонтальной децентрализацией называют влияние на процесс принятия решений неруководителей, то есть представителей техноструктуры, вспомогательных отделов или операционного ядра.

2, a. Селективная децентрализация имеет место в том случае, когда права на принятие решений разных типов распределяются по разным частям организации: например, финансовые решения принимаются на стратегическом апексе, маркетинговые решения - во вспомогательных подразделениях, производственные решения - на нижнем уровне срединной линии контролерами первого уровня. В этом случае организация может быть децентрализованной в одних вопросах и централизованной в других.

2, б. Параллельная децентрализация подразумевает распределение прав на принятие решений всех типов в одном месте организационной структуры. Например, финансовые, маркетинговые и производственные решения принимаются в срединной линии менеджерами подразделений. Организация либо централизована, либо децентрализована (во всех вопросах).

Эффективность организационной структуры (по Г. Минцбергу) зависит, с одной стороны, от соответствия значений параметров дизайна ситуационным факторам, с другой, от внутренней согласованности значений этих параметров.

В качестве ситуационных факторов обычно выделяют следующие: возраст и размер организации, характер технической системы, характеристики внешней среды организации и власть. Г. Минцберг разработал совокупность гипотез, отражающих взаимосвязи между значениями проектных параметров и ситуативных факторов ${ }^{1}$ :

чем старше организация, тем более формализовано ее поведение;

структура отражает эпоху возникновения отрасли;

чем крупнее организация, тем сложнее ее структура (т. е. рабочие задачи являются более специализированными, организационные единицы - более дифференцированными, административный компонент - более развитым);

чем крупнее организация, тем больше средний размер ее организационных единиц;

чем крупнее организация, тем сильнее формализовано ее поведение;

чем больше регулируется техническая система, тем сильнее формализована операционная деятельность и бюрократизирована структура операционного ядра;

чем сложнее (труднее для понимания) техническая система, тем более развита неоперационная структура (в частности, многочисленнее и профессиональнее вспомогательный персонал), тем избирательнее децентрализация (по отношению к специалистам персонала) и тем шире использование инструментов взаимодействий (для координации деятельности специалистов);

автоматизация операционного ядра превращает бюрократическую административную структуру в органическую;

чем динамичнее окружение, тем органичнее структура;

\footnotetext{
${ }^{1}$ Минцберг Г. Указ. соч.
} 
чем сложнее внешняя среда, тем более децентрализованной является структура;

чем разнообразнее рынки организации, тем больше она склонна к разделению на рыночно ориентированные организационные единицы (если имеется возможность использования эффекта масштаба);

крайняя враждебность окружения вынуждает любую организацию к временной централизации структуры;

несоразмерности окружения побуждают организацию к избирательной децентрализации в дифференцированные рабочие созвездия;

чем жестче внешний контроль над организацией, тем более централизованной и формализованной является ее структура;

стремление к власти членов организации приводит к излишней централизации структуры;

мода обусловливает принятие структуры своего времени (и своей культуры), иногда даже вразрез с интересами организации.

Для характеристики организационных моделей, кроме классификации организационных конфигураций Г. Минцберга, используем следующие классификации: организационные культуры Ч. Хэн-ди ${ }^{1}$, стили руководства К. Левина $^{2}$, психологические типы ${ }^{3}$, временные ориентации планирования по Р. Акоффу ${ }^{4}$, конкурентных стратегий по М. Портеру 5 .

Рассмотрим кратко основные структурные конфигурации по Г. Минцбергу.

Простая структура. Здесь не развита техноструктура, незначительна численность вспомогательного персонала, слабо выражено разделение труда, незначительна дифференциация организационных единиц, относительно невысокая управленческая иерархия. Формализация поведения незначительна; планирование, обучение и инструменты взаимодействий используются в ограниченных масштабах. Основной координационный механизм - прямой контроль. В частности, права на принятие всех важнейших решений обычно сконцентрированы в руках главного исполнительного директора организации. Ключевая часть организации стратегическая вершина. Часто структура состоит из стратегической вершины (единственного руководителя) и органического операционного ядра, аппаратные специалисты обычно не являются штатными работниками организации. Группирование чаще всего происходит по функциональному принципу. Коммуникации осуществляются неформально. Основные параметры дизайна: централизация, органическая структура. Процесс принятия решений отличается гибкостью, централизация власти позволяет быстро реагировать на любые события во внешней среде. Формулирование стратегии является прерогативой руководителя. Цели организации - это его цели, организационные стратегии - это его видение. Ситуационные факторы, в которых используется такая структура, следующие: молодая малая фирма, простая динамичная внешняя среда, простая нерегулируемая техническая система, потребность во власти руководителя.

Механистическая бюрократия. Деятельность осуществляется в простой и

\footnotetext{
${ }^{1}$ Хэнди Ч. Типы организационных культур // URL: http://bsmei.narod.ru/dp/dp-kult.htm

${ }^{2}$ Классики менеджмента: энциклопедия. СПб.: Питер, 2001

3 Леонард Д., Строе С. Как заставить работать коллективный мозг компании // Управление знаниями. М.: Альпина Бизнес-Букс, 2006.

${ }_{5}^{4}$ Акофф Р. Акофф о менеджменте. СПб: Питер, 2002.

5 Портер М. Конкурентная стратегия: Методика анализа отраслей и конкурентов. М.: Альпина Бизнес-Букс, 2005.
} 
стабильной внешней среде. Чаще всего она встречается в зрелых, достаточно крупных организациях, выполняющих большие объемы требующих повторений и стандартизации операций. Возможность внедрения стандартов предполагает, что эти организации существуют достаточно длительное время. Механистические бюрократии обычно отождествляются с регулируемыми техническими системами, поскольку они программируют работу и, следовательно, таковая поддается формализации. Эти технические системы варьируются от самых простых до умеренно сложных, но не более того.

Деятельность таких организаций носит преимущественно однообразный, простой, повторяющийся характер; как следствие, труд в них в высокой степени стандартизирован. Операционное ядро характеризуется очень четким разделением труда на узко специализированные по вертикали и горизонтали задачи. Ключевым проектным параметром структуры является формализация поведения. Координация осуществляется посредством стандартизации процесса труда, поэтому в операционном ядре могут функционировать очень крупные подразделения. Основные параметры дизайна: формализация поведения, вертикальная и горизонтальная специализации, обычно функциональное группирование, крупные операционные единицы, вертикальная централизация и ограниченная горизонтальная децентрализация, планирование действий.

Ключевое значение в таких организациях приобретает техноструктура, где разрабатываются стандарты. Разнообразные правила и инструкции насквозь пронизывают механистическую бюрократию; формальные коммуникации преобладают на всех ее уровнях; решения принимаются в соответствии с цепочкой полномочий. Процесс формирования стратегии является нисходящим (по линейной иерархии), а самое большое значение придается планированию действий.

Профессиональная бюрократия. Основной координационный механизм стандартизация навыков и знаний (квалификации). Ключевая часть организации операционное ядро. Основные параметры дизайна: специальная подготовка, горизонтальная специализация, вертикальная и горизонтальная децентрализация. Ситуационные факторы: сложная, стабильная внешняя среда; нерегламентированная, не усложненная техническая система; модная.

Деятельность таких организаций стабильна, поэтому для них характерно «предопределенное, или прогнозируемое, в конечном итоге, стандартизированное» поведение. В то же время эта деятельность отличается сложностью и, следовательно, должна контролироваться непосредственно выполняющими ее операторами. Поэтому организация обращается к координационному механизму, который предусматривает одновременно стандартизацию и децентрализацию - а именно, к стандартизации навыков и знаний (квалификации) и связанный с ними параметр - индоктринацию. На работу в организацию принимают соответствующим образом обученных и воспитанных специалистов - профессионалов, - формирующих операционное ядро, отличие которого состоит в том, что его члены в значительной мере самостоятельно контролируют процесс труда. Работа профессиональных операторов в высшей степени специализирована по горизонтали и расширена по вертикали. Контроль над процессом труда означает, что профессионал работает относительно независимо от коллег, но в тесном взаимодействии с клиентами.

В работе профессионалу необходимо решить две задачи:

- классифицировать, или «диагностировать» потребности клиента с учетом данной ситуации, то есть определить необходимость применения той или иной 
стандартной программы;

- применить, или выполнить данную программу.

Структура профессиональной бюрократии является одновременно функциональной и рыночно ориентированной. Еще одна сложная и разветвленная часть организации - вспомогательный персонал, занятый в основном обслуживанием деятельности операционного ядра. Техноструктура и менеджмент срединной линии в профессиональной бюрократии развиты незначительно.

Эта конфигурация возникает там, где в операционном ядре организации преобладают профессионалы, выполняющие трудные для освоения и в то же время четко оговоренные процедуры.

Дивизионалъная форма. Основной координационный механизм стандартизация выпуска. Ключевая часть организации - срединная линия (руководители подразделений). Основные параметры дизайна: рыночное группирование, система контроля над исполнением, ограниченная вертикальная децентрализация.

Подобно профессиональной бюрократии, дивизиональная форма представляет собой не столько интегрированное целое, сколько набор объединенных центральной административной структурой (штаб-квартирой) полуавтономных «организмов» подразделений или дивизионов.

Дивизиональная форма использует в верхней части срединной линии рыночный принцип группирования организационных единиц. Подразделения создаются в соответствии с обслуживаемыми рынками и наделяются всеми необходимыми для их обслуживания операционными функциями. Подобное структурное устройство естественно приводит к ярко выраженной децентрализации, но она существенно ограничена и зачастую сводится к делегированию полномочий нескольких высших менеджеров центра чуть более многочисленным руководителям подразделений. Другими словами, дивизиональная форма предусматривает децентрализацию параллельного, ограниченного вертикального типа.

Штаб-квартира обычно сохраняет за собой прерогативу реализации следующих функций: разработка корпоративной стратегии, распределение финансовых ресурсов, контроль и координация деятельности подразделений в рамках реализации стратегии.

Ситуационные факторы: диверсифицированные рынки; зрелая, крупная организация; властные потребности менеджеров среднего звена; модная.

Адхократия. Основной координационный механизм: взаимное согласование. Ключевая часть организации: вспомогательный персонал (в административной адхократии, в операционной адхократии - наряду с операционным ядром). Основные параметры дизайна: инструменты взаимодействия, органическая структура, избирательная децентрализация, горизонтальная специализация, обучение, функциональное и рыночное группирование одновременно.

Ситуационные факторы: сложная динамичная (иногда неравноправная) внешняя среда; молодость; сложная и часто автоматизированная техническая система; модная.

Адхократия в состоянии объединить специалистов разных профессий в слаженно функционирующие ad hoc (специальные) проектные команды. Инновационная деятельность означает отход от укоренившихся схем, а значит, в деле координации инноваторская организация не может полагаться ни на одну из форм стандартизации. Из всех конфигураций именно адхократия демонстрирует наименьшее «почтение» к классическим принципам менеджмента, и прежде всего к 
единоначалию. Информационные процессы и процессы принятия решений протекают неформально и гибко, что и требуется для эффективного создания инноваций. Кроме того, это предполагает прерывание цепочки властных полномочий в случае необходимости.

По сравнению с простой структурой, адхократия также имеет гибкую структуру, но иного типа, действующую в условиях сложного окружения. Адхократия должна привлекать и наделять полномочиями экспертов - людей, которые приобрели знания и умения благодаря специальному образованию и подготовке. Но в отличие от профессиональных бюрократий для достижения координации адхократия не может опираться на стандартизированные навыки своих специалистов, поскольку стандартизация не способствует инновациям. Если каждый специалист профессиональной бюрократии может работать в одиночку, то специалисты адхократии должны объединяться в многопрофильные команды, каждая из которых формируется для реализации конкретного инновационного проекта. Адхократия использует матричную структуру. Специалисты организации группируются в функциональные единицы и одновременно распределяются на проектные команды для выполнения своих непосредственных обязанностей. Высокая сложность труда также исключает прямой контроль, остается взаимное согласование. Упор на данный механизм координации требует выдвижения на первый план соответствующего параметра дизайна -набора инструментов взаимодействий. Адхократии необходимы менеджеры-интеграторы, отвечающие за связи и взаимодействия, они координирую деятельность внутри и между функциональными единицами и проектными командами. Поэтому в адхократии множество менеджеров: функциональных, ответственных за интеграцию, руководителей проектов. Следовательно, «норма управляемости» в адхократии невелика.

Децентрализация селективная, одновременно горизонтальная и вертикальная. Право принимать решения распределяются между менеджерами и неменеджерами всех уровней иерархии в соответствии с требованиями решения конкретной задачи.

В мировой практике существует целый ряд типологий организационных структур. Проблемам формирования и управления культурой организации посвящена монография проф. А. Н. Асаула ${ }^{1}$. Рассмотрим одну из самых известных - типологий Чарлза Хэнди, где организационные культуры делятся на четыре типа: культура власти, культура роли, культура задачи и культура личности ${ }^{2}$.

Культура личной власти, или Зевса, основывается на владении ресурсами. Организации с такой культурой имеют жесткую структуру, высокую степень централизации, немногочисленные правила и процедуры. Они авторитарны, подавляют инициативу и жестко контролируют работников. Успех предопределяется своевременным выявлением проблем и высокой квалификацией руководителей, позволяющими быстро принимать и реализовывать решения. Такая культура характерна для молодых коммерческих фирм, действующих в условиях жесткой конкуренции. Люди, предпочитающие этот тип культуры склонны к интуитивному и целостному мышлению. Они быстро приходят к решению, проверяют его в уме на пригодность, и если оно их не устраивает, переходят к рассмотрению другого варианта. Последовательный, пошаговый логический анализ не является их епархией и кажется им нудным занятием. В этой культуре прежде всего ценятся контроль за

${ }^{1}$ Культура организации: проблемы формирования и управления / А. Н. Асаул и др. СПб.: Гуманистика, 2006.

${ }^{2}$ Хэнди Ч. Типы организационных культур. URL: http://bsmei.narod.ru/dp/dp-kult.htm 
ресурсами и личная харизма.

Культура роли, или Аполлона, основывается на системе правил и инструкций. Ей присущи четкая специализация участников и распределение их ролей, прав и обязанностей, ответственности, обеспечивающие административный успех. Для нее не характерны гибкость и инновационность. Источником власти в ней является должность. Такая культура свойственна крупным корпорациям и государственным учреждениям. Такой стиль мышления отличается логичностью, последовательностью и аналитичностью. Эффективность в подобных организациях склонны трактовать как упрощение задачи и разбиение ее на простые, но существенные подзадачи.

Поскольку аполлонийцы ценят власть, источником которой является сила положения, то они воспринимают как вознаграждение увеличение своих формальных полномочий, повышение по службе и сопутствующие этому символические атрибуты статуса (кабинет, служебная машина и т. д).

Культура задачи, или Афины, приспособлена к управлению в экстремальных или постоянно меняющихся ситуациях и обеспечивает быстрое решение проблем на основе сотрудничества, коллективного творчества. Основой власти в условиях такой культуры служат профессионализм и обладание информацией. Организация представляет собой сеть взаимосвязанных подразделений-команд, каждое из которых в значительной степени автономно, но несет определенную ответственность в рамках общей стратегии организации.

Эта культура в качестве оснований для власти или влияния признает только опыт, возраст не производит никакого впечатления, также как стаж работы в организации и близость к руководству. Для того чтобы внести вклад в работу своей команды, человеку необходим талант, творческое мышление, свежесть взгляда и интуиция. В этой культуре процветают молодые таланты и творчество является наградой. Молодость, энергия и творчество, которые ассоциируются с Афиной, как нельзя лучше отвечают потребностям культуры задачи.

Афиняне - разрешители проблем. Проблемы с их точки зрения лучше всего решать при соединении творческого мышления с логикой. Кроме того, фундаментальным моментом процесса решения проблем является групповая работа, поскольку несколько умов всегда лучше одного.

Культура личности, или Диониса, связана с эмоциональным началом. Она основывается на творческих ценностях и объединяет людей для достижения их личных целей. Решения здесь принимаются на основе согласия участников, поэтому задачей власти является их координация. Эту культуру обычно предпочитают профессионалы, она позволяет им сохранять свою независимость, личную свободу и подлинность. Они становятся частью организации (такие организации правильней называть ассоциациями), состоящей из их коллег, лишь потому, что это дает им дополнительные возможности, гибкость и поддержку.

Отличительной чертой дионисийцев можно считать их уверенность (неважно обоснованную или нет) в том, что они уже ничему не могут научиться от любого конкретного человека - только на основе опыта.

Классификация стилей руководства Курта Левина ${ }^{1}$ характеризует различные типы взаимоотношений между руководителями и подчиненными. Выделяются следующие стили руководства:

1. Авторитарный стиль руководства - стиль лидера, который имеет тенденцию к централизации власти, диктату в методах работы, единоличному принятию решений

\footnotetext{
${ }^{1}$ Классики менеджмента: энциклопедия. СПб.: Питер, 2001.
} 
и ограничению участия подчиненных в этом процессе.

2. Демократичный стиль - стиль, свойственный лидеру, который имеет тенденцию к вовлечению подчиненных в процесс принятия решений, делегированию полномочий, стимулированию работников к участию в самостоятельном выборе методов работы и целей и использованию обратной связи для обучения подчиненных.

3. Стиль невмешательства - стиль лидера, который предоставляет коллективу полную свободу действий в процессе принятия решений и разрешает совершенно самостоятельно выбирать способ выполненной работы.

В соответствии с концепцией мозгового доминирования Неда Херрманна, мозг человека делится на четыре части, каждая из которых отвечает за свой тип мышления: А - логичность, аналитика, материализм; Б - планирование, организация вещей, внимание к деталям; В - чувства, эмоции, внутреннее мышление и духовная жизнь; Г - целостность, концептуальность мышления, артистичность. В зависимости от опыта у каждого человека складываются предпочтения к какому-то одному стилю мышления, который становится преобладающим. Нед Херрманн разработал методику выявления психологических доминант.

Временные ориентации планирования описаны Расселом Акоффом ${ }^{1}$. Они определяют то, каким способом разрабатывается план, на что ориентируется плановик.

Реактивное планирование - это ориентированное снизу вверх тактическое планирование. Стратегия образуется посредством сложения совокупности независимо принятых решений. Оно начинается в организационных единицах самого низкого уровня с выявления недостатков, угроз, с которыми они сталкиваются. Затем составляется проект работ, включающий установление причин выявленных недостатков и угроз, а также определение способов их устранения или подавления для возвращения системы в первоначальное состояние. Затем на основе анализа затраты-выгоды расставляются приоритеты по отдельным позициям проекта. И наконец, исходя из оценки количества требуемых ресурсов для данных проектных работ, составляется их перечень с учетом приоритетов. Составленный таким образом список проектных заданий представляет собой план данной организационной единицы.

Планы подразделений передаются в организационную единицу следующего, более высокого уровня, где они редактируются, координируются и интегрируются в подготовленный аналогичным образом план. Данный процесс продолжается снизу вверх, пока все планы не соберутся на самом высоком организационном уровне, где они снова редактируются, координируются и интегрируются с проектами высшего уровня. Таким образом будет получен корпоративный план.

Преактивное планирование - это стратегически ориентированное планирование сверху вниз, когда конечные задачи определяются четко и ясно, а тактика оставлена на рассмотрение отдельных организационных единиц. Такое планирование имеет две части: предвидение и подготовку. В процессе предвидения разрабатывается несколько долгосрочных прогнозов. Затем прогнозы и стратегический «чистый лист» спускаются сверху на все более низкие уровни организации. Каждый уровень адаптирует прогноз и результаты анализа к своим специфическим условиям и возможностям и выбирает направления и цели, совместимые с направлениями и целями организации в целом. Затем на основе этих задач и целей в общих чертах формулируются конкретные программы. Совокупность прогностических заявок,

\footnotetext{
${ }^{1}$ Акофф Р. Акофф о менеджменте. СПб: Питер, 2002.
} 
принятых обязательств и программ их выполнения составляет план каждой организационной единицы. Все планы рассматриваются на более высоких уровнях. Далее планы, составленные на разных уровнях, интегрируются в план более высокого уровня, а планы, составленные на одном уровне, координируются друг с другом.

Инактивное планирование. Характерна удовлетворенность настоящим. Считается, что равновесие в положении экономической организации на рынке достигается естественным путем, автоматически. А значит, главным принципом планирования должно быть правило: «Планировать минимум необходимого, чтобы не изменить естественного хода вещей». Предотвращение изменений и сохранение своего «стиля» становится основной целью использующих инактивное планирование организаций. При принятии решений господствуют бюрократизм и волокита. Принятие решений осуществляется в рамках различных, бесконечно заседающих комиссий. Считается основным злом и строго карается нелояльность к организации и ее целям. Предыстория проблемы плановиков не интересует.

В планировании большую часть времени занимают сбор фактов и их первичная обработка. Аналитические отделы бывают чрезвычайно раздуты - нужно постоянно «держать руку на пульсе». Наиболее ценными работниками признаются не те, кто обладает наибольшим опытом, а те, кто умеет схватить суть происходящего, имеет многочисленные связи, то есть так называемые знающие люди ${ }^{1}$.

Интерактивное планирование направлено на установление контроля над будущим. Оно основано на уверенности в том, что будущее организации зависит не только от того, что будет делаться между «сейчас» и «потом», но и в не меньшей степени от того, что уже сделано. Поэтому такой тип планирования состоит из сценария желаемого будущего и выбора или изобретения путей его достижения в максимальной степени близко к задуманному. Р. Акофф описывает пять фаз интерактивного планирования: разработка опорного сценария; разработка идеализированного сценария и сравнение; планирование средств и ресурсов, с использованием которых предполагается устранить разрывы; выполнение и контроль.

Классификация стратегий Майкла Портера ${ }^{2}$ - это классификация способов создания и поддержания конкурентного преимущества на рынке. Существует три типа конкурентных преимуществ -низкие издержки, дифференциация и занятие ниши. Выбор типа конкурентного преимущества осуществляется после обстоятельного анализа рыночной ситуации, включающей в себя анализ конкурентных сил и предпочтений потребителей.

Стратегия низких издержек состоит в максимальном снижении уровня себестоимости производимой продукции. Низкая себестоимость достигается за счет стандартизации товара, достижения эффекта масштаба, тщательного анализа процессов с целью выявления резервов снижения себестоимости и снижения уровня качества продукции до среднего уровня. Эта стратегия реализуется на массовых однородных рынках, где наблюдается высокая ценовая эластичность спроса.

Стратегия дифференциации - это стратегия создания особенного по каким-то характеристикам продукта. В основе дифференциации может лежать высокая надежность продукции, привлекательный дизайн, широкий ассортимент, особенное обслуживание и др.

${ }^{1}$ Асаул А. Н, Абаев Х. С, Гордеев Д. А. Оценка конкурентных позиций субъектов предпринимательской деятельности / под ред. А. Н. Асаула. СПб.: АНО ИПЭВ, 2007.

${ }^{2}$ Портер М. Конкурентная стратегия: методика анализа отраслей и конкурентов. М.: Альпина Бизнес-Букс, 2005. 
Вследствие наличия особенных качеств, выделяющих данный продукт, цена на него обычно выше среднего уровня. Стратегия используется на рынках, где потребители не чувствительны к цене, но восприимчивы к каким-то особенностям продукции.

Нишевая стратегия - это стратегия ухода в нишу. Ниша позволяет обезопасить себя от основных конкурентов компаниям, не обладающим достаточными ресурсами для того, чтобы вести полноценную конкурентную борьбу с лидерами рынка. Стратегия заключается в выделении на рынке небольшой категории потребителей, предъявляющих особые требования к продукции, и в максимально полном удовлетворении этих требований.

Сопоставив между собой и объединив друг с другом все приведенные выше классификации, получим классификацию предпринимательских моделей хозяйствования (табл. 3.4). 
Таблица 3.4.

Расширенная авторская классификация предпринимательских моделей хозяйствования

\begin{tabular}{|c|c|c|c|c|c|}
\hline $\begin{array}{l}\text { Составляющие } \\
\text { модели 7S }\end{array}$ & $\begin{array}{l}\text { Автор классификации, аспекты } \\
\text { составляющей (см. стр. 155) }\end{array}$ & Коммерческая модель & $\begin{array}{l}\text { Функциональная } \\
\text { (бюрократическая) модель }\end{array}$ & $\begin{array}{l}\text { Инновационная } \\
\text { (процессная) модель }\end{array}$ & $\begin{array}{l}\text { Профессиональная } \\
\text { (экспертная) модель }\end{array}$ \\
\hline Структуры & \begin{tabular}{|lll}
$\begin{array}{l}\text { Конфигурация } \\
\text { Минцбергу) }\end{array}$ & (по & Г. \\
\end{tabular} & Простая конфигурация & $\begin{array}{l}\text { Механистическая } \\
\text { бюрократия } \\
\end{array}$ & Адхократии & $\begin{array}{l}\text { Профессиональная } \\
\text { бюрократия }\end{array}$ \\
\hline \multirow[t]{3}{*}{ Стиль } & $\begin{array}{l}\text { Организационная культура (по } \\
\text { Ч. Хэнди }\end{array}$ & Культура власти & Культура роли & Культура задачи & Культура личности \\
\hline & Стиль управления $^{1}$ & Авторитарный & \begin{tabular}{|l|} 
Бюрократический (власть, \\
ограниченная правилами)
\end{tabular} & $\begin{array}{l}\text { Самоуправление } \\
\text { (самоорганизация) }\end{array}$ & Либеральный \\
\hline & Способы принятия решений & $\begin{array}{l}\text { Интуитивное принятие } \\
\text { решений }\end{array}$ & $\begin{array}{l}\text { Формализация процессса } \\
\text { принятия решения }\end{array}$ & «Создание решения» & Опыт \\
\hline Персонал & $\begin{array}{l}\text { Комфортно чувствующий себя } \\
\text { в компании и добивающийся } \\
\text { успеха психологический тип } \\
(\text { по методу психологических } \\
\left.\text { доминант Неда Херрманна }{ }^{2}\right) \\
\end{array}$ & $\begin{array}{l}\text { Оратор, музыкальный, } \\
\text { одухотворенный, эмо- } \\
\text { циональный, обладает } \\
\text { навыками межлич- } \\
\text { ностного общения } \\
\end{array}$ & $\begin{array}{l}\text { Планировщик, } \\
\text { управляемый, } \\
\text { консервативный, } \\
\text { организатор, } \\
\text { исполнительный } \\
\end{array}$ & \begin{tabular}{|l} 
Создатель концепций, \\
умеет обобщать, имеет \\
богатое воображение, \\
цельный, артистичный
\end{tabular} & $\begin{array}{l}\text { Умеет решать проб- } \\
\text { лемы, знает математику, } \\
\text { обладает тех-ническим } \\
\text { складом ума, аналитик, } \\
\text { рациональный }\end{array}$ \\
\hline \multirow[t]{3}{*}{ Стратегия } & $\begin{array}{|lll|}\begin{array}{l}\text { Подходы } \\
\text { стратегии }\end{array} & \text { к } & \text { разработке } \\
\end{array}$ & $\begin{array}{l}\text { Видение } \\
\text { предпринимателя }\end{array}$ & Планирование & $\begin{array}{l}\text { Формирование } \\
\text { процесса }\end{array}$ & $\begin{array}{l}\text { Формирование от } \\
\text { убеждений операторов }\end{array}$ \\
\hline & \begin{tabular}{|lc} 
Временная & ориентация \\
планирования (по Р. Акоффу)
\end{tabular} & $\begin{array}{l}\text { Преактивное } \\
\text { планирование }\end{array}$ & Инактивное планирование & $\begin{array}{l}\text { Интерактивное } \\
\text { планирование }\end{array}$ & $\begin{array}{l}\text { Реактивное планирова- } \\
\text { ние }\end{array}$ \\
\hline & $\begin{array}{l}\text { Содержание стратегий (по } \\
\text { М. Портеру }{ }^{5} \text { ) }\end{array}$ & Нишевые стратегии & $\begin{array}{l}\text { Стратегия } \\
\text { издержек }\end{array}$ & Первопроходец & $\begin{array}{l}\text { Дифференциация } \\
\text { качеству решения }\end{array}$ \\
\hline $\begin{array}{l}\text { Ключевые } \\
\text { компетенции }\end{array}$ & Ядро компетенций & Гибкость & $\begin{array}{l}\text { Экономическая } \\
\text { Эффективность }\end{array}$ & \begin{tabular}{|l} 
Инновации, \\
исследования \\
\end{tabular} & Высокое качество работы \\
\hline Системы & Наиболее значимые подсистемы & Власти & Операционная & Социальная & Информационная \\
\hline Общие ценности & & Общее видение & Стабильность & Поток, обучение & Профессионализм \\
\hline \multicolumn{6}{|c|}{ 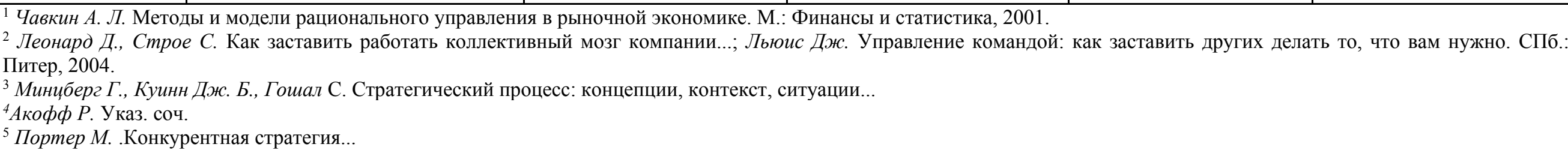 } \\
\hline
\end{tabular}


Для каждой предпринимательской модели хозяйствования характерен свой набор ситуационных факторов (табл. 3.5).

Таблища 3.5

\section{Наборы ситуационных факторов предпринимательских моделей хозяйствования}

\begin{tabular}{|c|c|c|c|c|c|}
\hline $\begin{array}{l}\text { Ситуационные } \\
\text { факторы }\end{array}$ & $\begin{array}{l}\text { Автор } \\
\text { классификации, } \\
\text { аспекты } \\
\text { составляющей }\end{array}$ & $\begin{array}{l}\text { Коммерческая } \\
\text { модель }\end{array}$ & $\begin{array}{l}\text { Функциональная } \\
\text { (бюрократическая) } \\
\text { модель }\end{array}$ & \begin{tabular}{|l} 
Инновационная \\
(процессная) \\
модель
\end{tabular} & $\begin{array}{l}\text { Профессиональна } \\
\text { я (экспертная) } \\
\text { модель }\end{array}$ \\
\hline $\begin{array}{l}\text { Внешняя } \\
\text { среда }\end{array}$ & $\begin{array}{l}\text { Сложность, } \\
\text { динамичность }\end{array}$ & $\begin{array}{l}\text { Простая, } \\
\text { динамичная }\end{array}$ & $\begin{array}{l}\text { Простая, } \\
\text { стабильная }\end{array}$ & $\begin{array}{l}\text { Сложная, } \\
\text { динамичная }\end{array}$ & $\begin{array}{l}\text { Сложная, } \\
\text { стабильная }\end{array}$ \\
\hline $\begin{array}{l}\text { Тип } \\
\text { производствен } \\
\text { ной системы }\end{array}$ & Дж. Вудворд & \begin{tabular}{|l|} 
Единичное \\
производство
\end{tabular} & $\begin{array}{l}\text { Массовое } \\
\text { производство }\end{array}$ & $\begin{array}{l}\text { Уникальный } \\
\text { проект или } \\
\text { непрерывный } \\
\text { поток }\end{array}$ & $\begin{array}{l}\text { Серийное } \\
\text { производств } \\
\text { о }\end{array}$ \\
\hline $\begin{array}{l}\text { Возраст и } \\
\text { размер } \\
\text { организации }\end{array}$ & Г. Минцберг & $\begin{array}{l}\text { Молодая, } \\
\text { небольшая }\end{array}$ & \begin{tabular}{|lr} 
Зрелая, & средних \\
или & крупных \\
размеров &
\end{tabular} & $\begin{array}{l}\text { Молодая, } \\
\text { средних } \\
\text { размеров }\end{array}$ & $\begin{array}{ll}\text { Зрелая, } & \\
\text { средних } \quad \text { или } \\
\text { крупных } \\
\text { размеров }\end{array}$ \\
\hline $\begin{array}{l}\text { Власть } \\
\text { мода }\end{array}$ & Г. Минцберг & $\begin{array}{l}\text { Власть в } \\
\text { руках } \\
\text { руководителя }\end{array}$ & $\begin{array}{l}\text { Ограниченная } \\
\text { горизонтальная } \\
\text { децентрализация }\end{array}$ & $\begin{array}{l}\text { Децентрализац } \\
\text { ия, модная }\end{array}$ & $\begin{array}{l}\text { Децентрализа } \\
\text { ция, модная }\end{array}$ \\
\hline
\end{tabular}

Составляющие классификации - это модели в чистом виде (по аналогии с Пентагоном конфигураций Г. Минцберга). На практике же, вследствие уникальности ситуационных условий, конкретными предпринимательскими структурами используются модели-гибриды, сочетающие в себе свойства нескольких моделей классификации. Представление о зависимостях, лежащих в основе формирования таких гибридных моделей дает Пентагон Г. Минцберга (рис. 3.8).

Обоснованность использованных в качестве базы данной классификации структурных зависимостей, выявленных Г. Минцбергом, не вызывает сомнения результаты его исследования подтверждаются подавляющим большинством специалистов. Для обоснования же предлагаемого расширения указанной классификации был проведен всесторонний анализ деятельности четырех компаний г. Братска, имеющих структуры, максимально соответствующие одному из типов конфигурации Г. Минцберга. Этот анализ подтвердил выдвинутую гипотезу о наличии описанных в этом разделе зависимостей в модели «7S». Анализ заключался в подробном опросе от трех до семи представителей каждой компании. 


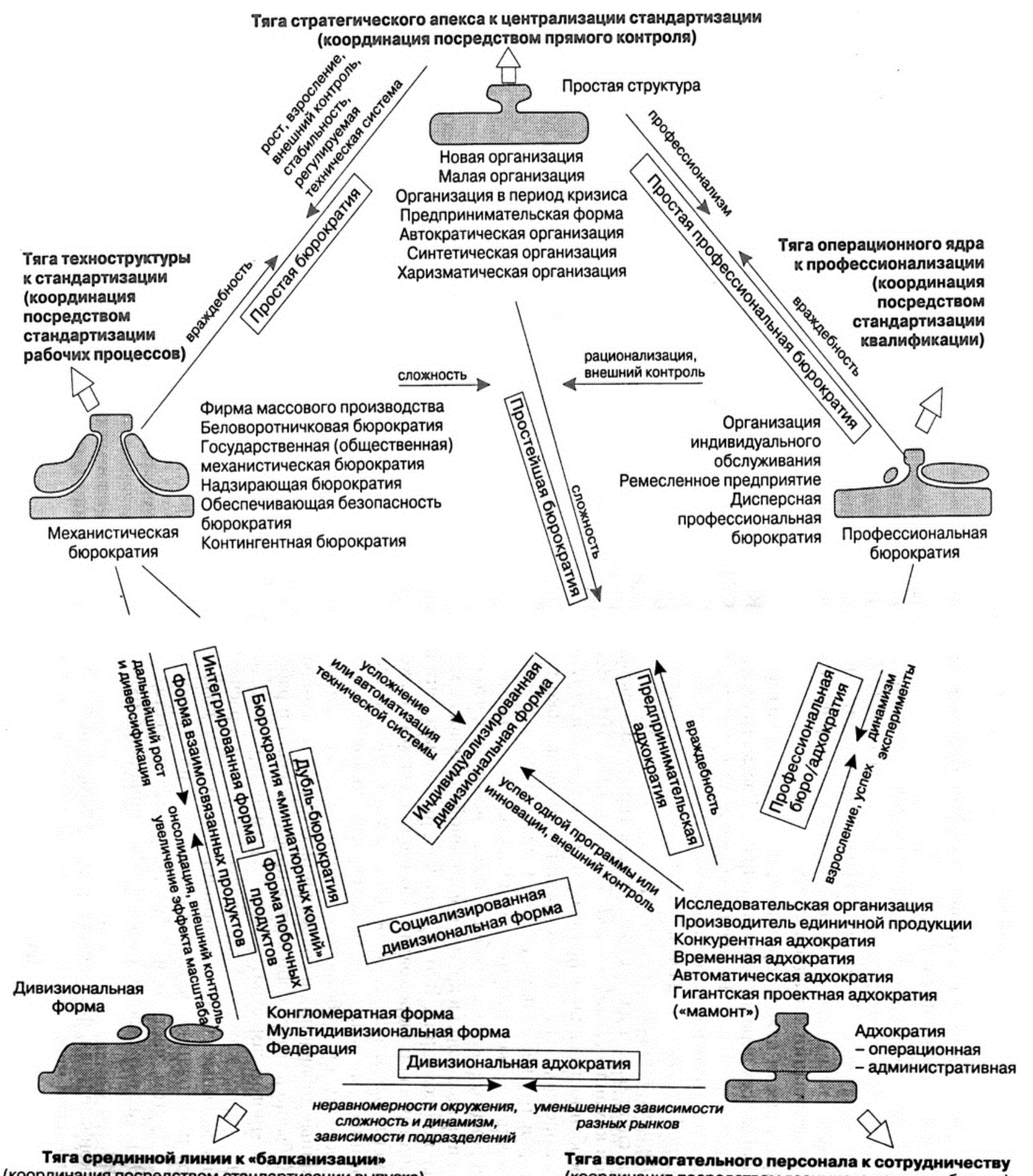
(координация посредством стандартизации выпуска) (координация посредством взаимного приспособления)

Рисунок 3.8. - Пентагон Г. Минцберга ${ }^{1}$

${ }^{1}$ Минцберг Г. Структура в кулаке: создание эффективной организации /Г. Минцберг. СПб.: Питер, 2004. - 512 с 


\section{3. КОНЦЕПЦИЯ ОБУЧАЮЩИХСЯ ОРГАНИЗАЦИЙ - ОСНОВА ДЛЯ ФОРМИРОВАНИЯ ИННОВАЦИОННОГО ПРОЦЕССА, ОБЕСПЕЧИВАЮЩЕГО СОЗДАНИЕ НОВОГО ЗНАНИЯ}

В соответствии с концепцией J. Е. Огг «создание знания включает не только инновации, но и обучение, которое может упрочить и развить подход к повседневной трудовой деятельности» ${ }^{1}$. В соответствии с целевыми задачами настоящего исследования рассмотрим концепцию обучающихся организаций П. М. Сенге во взаимосвязи с психологической концепцией потокового состояния сознания М. Чиксентмихайи.

Концепция П. М. Сенге учитывающая полный спектр всех аспектов стратегии персонализации включает в себя пять взаимопроникающих дисциплин: системное мышление, личное совершенствование, анализ и корректировка интеллектуальных моделей, общее видение и групповое обучение. Охарактеризуем кратко суть каждой из дисциплин.

Системное мышление. Системное мышление означает умение распознавать существующие в той или иной ситуации структуры систем. Структура систем - это совокупность важнейших в данной ситуации факторов, связанных между собой причинными циклами.

В качестве базовых элементов причинных системных структур выделяют петли обратной связи - стабилизирующую и усиливающую - и задержки. Стабилизирующая обратная связь регулирует поведение системы с целью подавления любого отклонения от намеченной траектории движения (от устойчивого состояния). Стабилизирующая обратная связь действует всегда, когда у системы есть ориентир (норматив). Усиливающая же обратная связь приводит к разбалансированию состояния системы, увеличивая отклонения от устойчивого состояния. Термин «задержка» означает разделенность причины и следствия во времени, что происходит довольно часто вследствие объективных системных свойств ${ }^{2}$.

Из перечисленных элементов состоят более сложные системные структуры, которые, по мнению представителей системного подхода, определяют состояние (результативность и эффективность) системы. Наиболее распространенные структуры систем, которые встречаются практически повсеместно, выявлены, классифицированы и названы архетипами. В настоящее время, таковых насчитывается около двенадцати, девять из которых представлены в книге П. М. Сенге ${ }^{3}$ : уравновешивание с задержкой, пределы роста, подмена проблемы, размывание целей, эскалация, деньги к деньгам, трагедия общих ресурсов, неработающее решение, рост и недоинвестирование.

Использование системного подхода в качестве одной из основ обучающейся организации означает обучение сотрудников организации искусству распознавать действующие в ситуации архетипы и использовать принцип рычага, то есть находить такой фактор в структуре системы, небольшое воздействие на который приведет к значительным результатам.

${ }^{1}$ Orr J. E. Sharing Knowledge, Celebrating Identity: Community Memory in a Service Culture // Collective Remembring / Ens. Middleton D., Edwards D. Newbury Park, CA: Sage, 1990.

${ }^{2}$ О'Коннор Дж,, Макдермотт И. Искусство системного мышления: Необходимые знания о системах и творческом подходе к решению проблем. М.: Альпина Бизнес-Букс, 2006.

${ }^{3}$ Сенге П. Пятая дисциплина: искусство и практика самообучающейся организации. М.: ОлимпБизнес, 1999. 
На основании изучения публикаций по системному анализу нами была разработана следующая методика выявления системных архетипов:

1. Перечисление всех связанных напрямую с анализируемой ситуацией подсистем (например, социальная, производственная, маркетинговая и др. подсистемы).

2. Определение контрольных факторов, являющихся индикаторами каждой подсистемы. Речь идет об индикаторах, однозначно характеризующих состояние подсистемы.

3. Выявление взаимосвязей между факторами и схематическое изображение системного архетипа.

Личное совершенствование. «Способность организации обучаться определяется способностями обучаться ее сотрудников». По мнению П. М. Сенге, обучение означает развитие двух умений: способности глубже понимать существующую реальность и способности фокусироваться на желаемом будущем (видение). Разрыв между действительной реальностью и желаемым будущим является источником энергии для действия по устранению разрыва.

Для того чтобы сотрудник мог вглядеться в настоящее и у него могло возникнуть видение, человек должен быть максимально вовлечен в процесс труда. Такая включенность хорошо описывается, на наш взгляд, концепцией потока М. Чиксентмихайи. В соответствии с этой концепцией, поток - это особое состояние сознания, которое возникает, когда такие факторы как мотивация, наличие знаний и навыков и эмоциональное состояние находятся в гармонии друг с другом. Рассмотрим каждый из факторов.

Мотивация - это или внутреннее стремление человека сделать что-то (т.е. сила этого стремления), или внутренняя причина действия. До сих пор в теории менеджмента нет однозначного ответа на вопрос о том, как мотивировать (см., например, классический обзор теорий мотивации ${ }^{1}$. Однако кроме причины действия, большое значение имеют два аспекта: значимость цели и ее ясность, четкое понимание того, какого результата требуется достигнуть. Эта установки имеется в мотивационной теории постановки целей и в концепции М. Чиксентмихайи.

Наличие знаний $и$ навыков означает наличие необходимых знаний об объекте ментального анализа и навыков взаимодействия с этим объектом. Знаний и навыков должно быть достаточно для того, чтобы субъект сумел справиться с поставленной задачей. По сути, наличие необходимых знаний и навыков позволяет субъекту сконцентрироваться на тех или иных аспектах выполнения поставленной задачи. Эти знания и навыки можно условно поделить на 2 части: концептуальные - системное мышление и технические - знания и навыки в области собственной специализации.

Эмоциональное состояние. Все эмоции человека можно поделить на два типа: упадок (грусть, страх, беспокойство, скука) и подъем (радость, счастье, бодрость, открытость). Состояние упадка способствует отказу от активности, состояние подъема способствует активной деятельности субъекта. Эмоциональное состояние человека и уровень его активности, конечно же, связаны между собой, но эта связь обоюдна, что часто упускается из виду (рис. 3.9).

\footnotetext{
${ }^{1}$ Мескон М. Х., Альберт М, Хедоури Ф. Основы менеджмента. М.: Дело, 2002.
} 


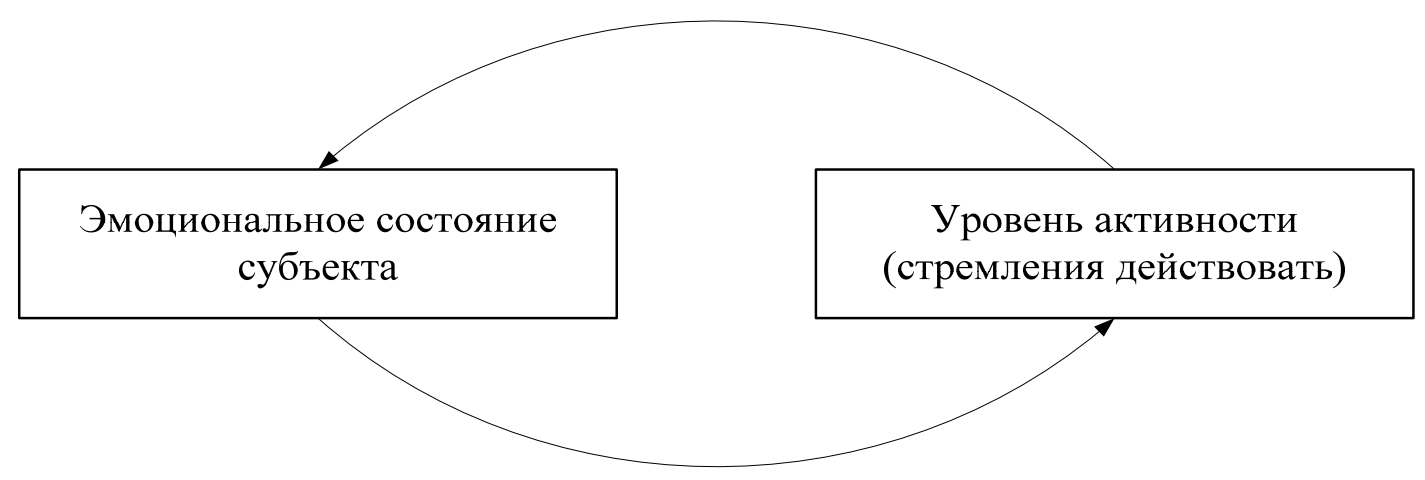

Рис. 3.9. Взаимная обусловленность состояния субъекта и уровня его активности

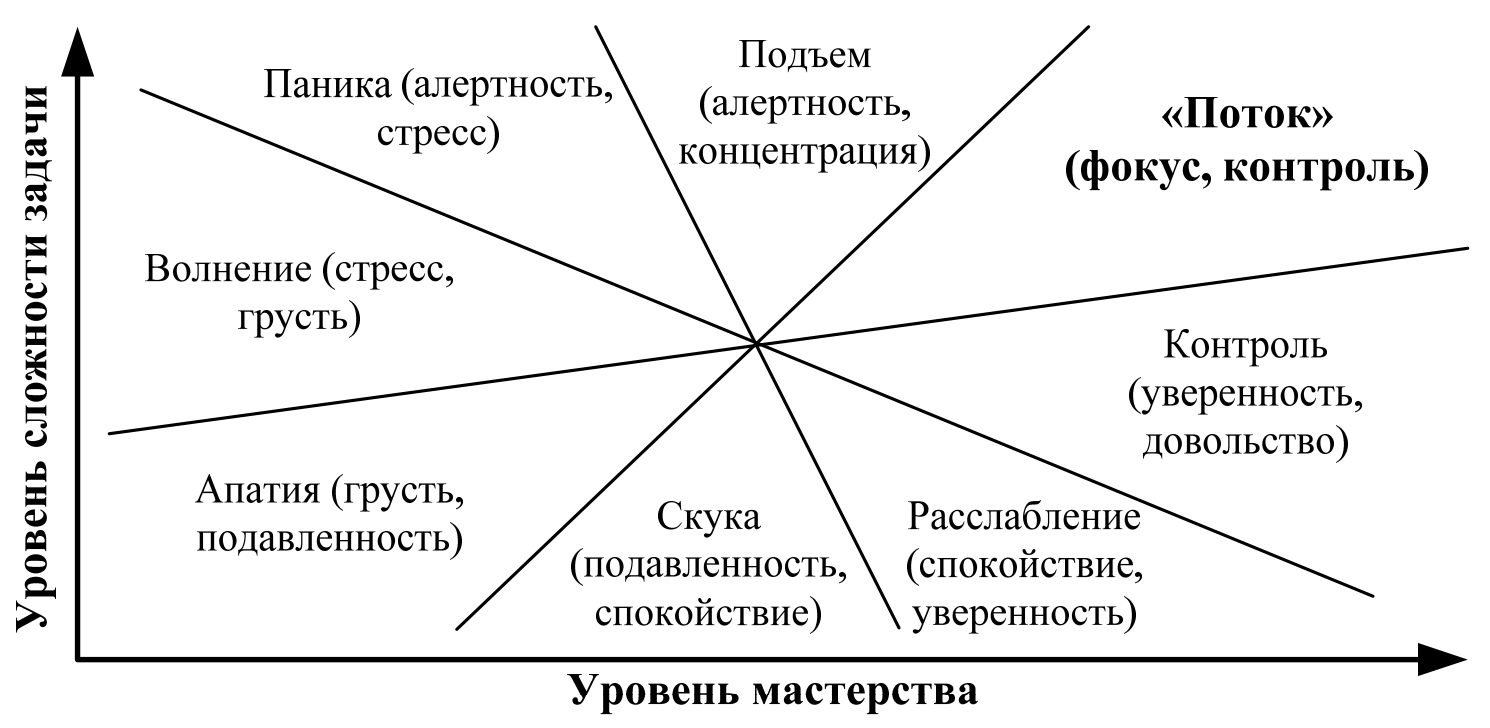

Рис. 3.10. Зависимость между состоянием человека и балансом между сложностью задачи и уровнем мастерства исполнителя по М. Чиксентмихайи

Состояние потока возникает, когда перед человеком поставлена четкая цель, имеются четкие правила осуществления деятельноети, результаты его труда очевидны ему (становятся очевидными сразу) и соблюдается определенный баланс между уровнем сложности задачи и уровнем его мастерства (рис. 3.10), т. е. состояние потока - это наличие некоей внутренней психической негэнтропии (см. рисунок). Кроме того, возникновению потока способствует наличие эмоционального состояния «подъем», но в большинстве случаев это не принципиально (рис. 3.11). В состоянии потока человек полностью сконцентрирован на решаемой задаче, а после ее решения испытывает чувство глубочайшего удовлетворения, полноты жизни. 


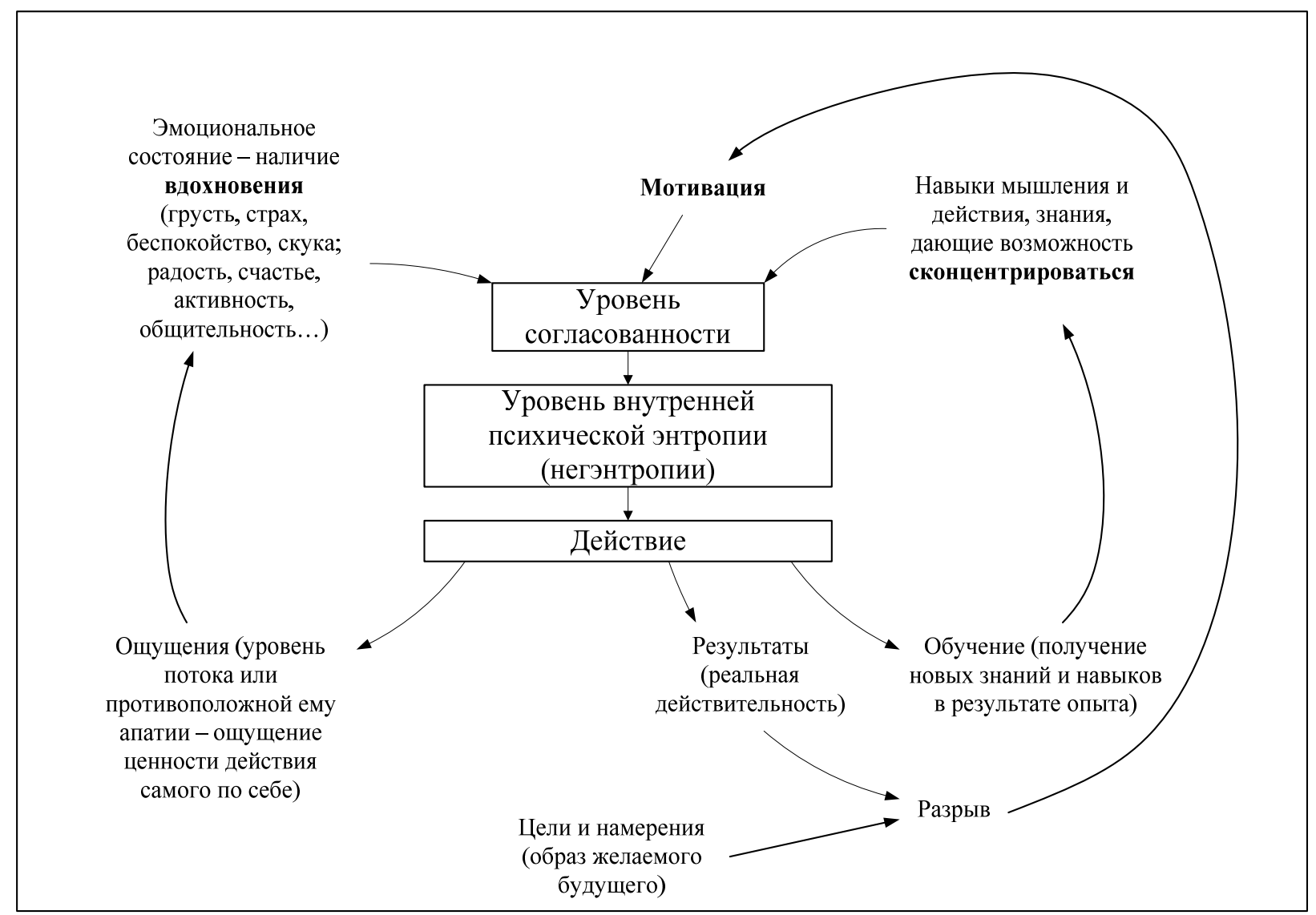

Рисунок 3.11 - Модель деятельности субъекта по М. Чиксентмихайи

Очевидно, переживание потоковых состояний сознания на рабочем месте является мощнейшим мотивационным фактором. Для возникновения этих состояний необходимо выполнение двух условий. С одной стороны, это означает что процесс труда должен быть спроектирован таким образом, чтобы вызывать соответствующий отклик у сотрудника. Вот как наличие этих свойств у процесса труда описывает Фредерик Герцберг: «только от сути работы зависит, сможет ли личность получить такое удовлетворение, которое будет усиливать его желание достигать лучших результатов труда» ${ }^{1}$. Это свойства - разнообразие выполняемой работы, ее значимость (уровень ответственности) и структурированность.

С другой стороны, субъект может самостоятельно изменить отношение к процессу труда. Одно обусловливает другое (рис. 3.12). Возникновению этого особого отношения к процессу труда способствует наличие в организации соответствующей атмосферы (или, другими словами, культуры), поощряющей сотрудников к личному совершенствованию, в процессе которого они совершенствуют процесс труда (что, естественно, приводит к повышению эффективности).

${ }^{1}$ Шелдрейк Дж. Теория менеджмента: от тейлоризма до японизации. СПб.: Питер, 2001. 


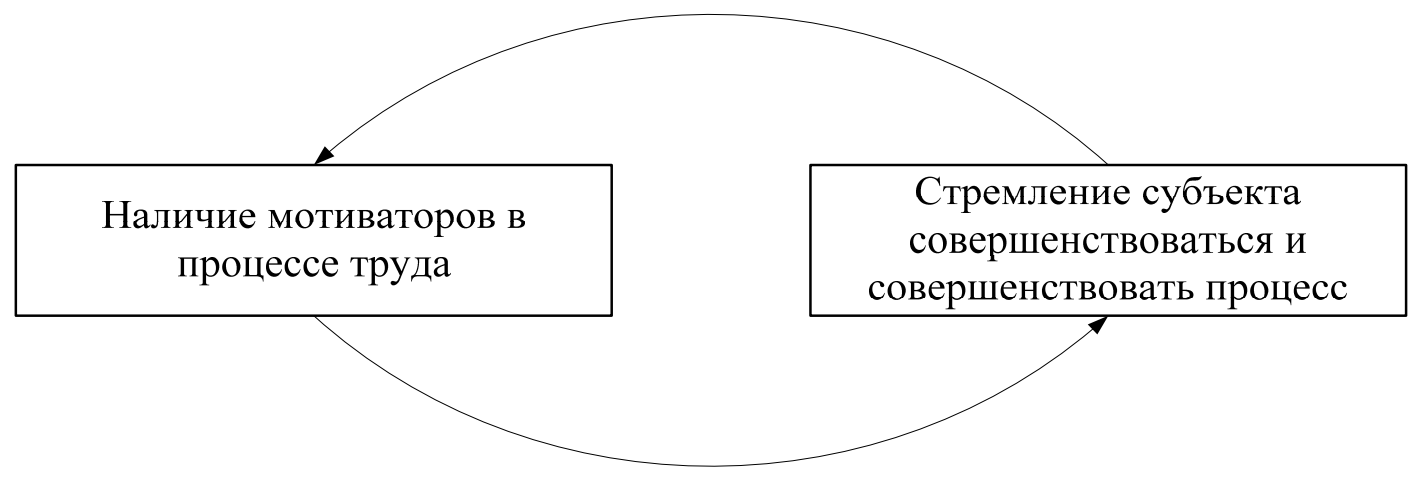

Рис. 3.12. Взаимная обусловленность системы бизнес-процессов и организационной культуры

Таким образом, создаваемая в организации атмосфера должна обладать следующими признаками:

• каждый сотрудник обладает своим собственным видением, мечтой;

- сотрудники обладают искусством системного мышления;

• в организации царят дух пытливости и приверженности истине, дух новаторства;

- открытость во взаимоотношениях;

• руководители - пример неустанного личного совершенствования.

Интеллектуальные или ментальные модели - это глубоко укоренившиеся представления людей о мире. Эти представления оказывают непосредственное влияние на восприятие действительности, а значит, по большей части, определяют поведение субъектов. Интеллектуальные модели могут быть индивидуальными и групповыми. Индивидуальные - это модели, выработанные индивидом самостоятельно; групповые же ментальные модели разделяются группой лиц.

Интеллектуальные модели снижают неопределенность (упрощая реальность) и позволяют повысить эффективность и результативность принимаемых управленческих решений, если они соответствуют действительной реальности. Однако они же превращаются в фактор неэффективности в том случае, когда перестают соответствовать действительности. Последнее рано или поздно происходит вследствие того, что модели остаются неизменными, а окружающая действительность находится в постоянном изменении. Следовательно, требуется постоянный пересмотр и обновление комплекса моделей как индивидуального, так и группового уровней.

И актуальность этой задачи тем выше, чем больше ответственность субъекта, использующего ментальную модель для принятия решения.

Наиболее распространенная проблема, связанная с интеллектуальными моделями, заключается в том, что эти модели вообще не обновляются и не пересматриваются. Со временем это приводит к патологической неприспособленности сотрудников к каким-либо организационным изменениям. Причины этой проблемы - в плохом руководстве, точнее в наличии на предприятии неэффективной и слабой организационной культуры. Культура взаимосвязана с другими организационными подсистемами, такими как операционная система организации, финансовая структура или тип организационной структуры. Эта взаимная обусловленность приводит к существованию нескольких четко различимых организационных типов, которые подробнее исследованы в главе 2 настоящей работы.

Безусловно, интеллектуальные модели оказывают свое влияние и сами находятся 
под влиянием основных факторов возникновения потока - наличие вдохновения, мотивация и уровень использования имеющихся навыков и знаний и стремление их расширять. умений:

Дисциплина интеллектуальных моделей подразумевает развитие следующих

неустанно проверять истинность той или иной действующей модели, т.е. соответствие модели фактам;

распознавать и управлять переходом от наблюдения за происходящим к абстракции (т. е. к возникновению интеллектуальной модели);

быть открытым, т. е. готовность обсуждать собственные интеллектуальные модели с коллегами;

исследование вопроса (т. е. заинтересованности в глубоком понимании сути анализируемого вопроса) и защиту собственной позиции (т. е. готовности отстаивать собственную точку зрения);

различать официальные теории (то, что декларируется) и фактически действующие интеллектуальные модели (то, что в действительности определяет поведение).

Всеобщее видение организации - это представления о будущем, которые разделяются подавляющим большинством сотрудников организации. Всеобщее видение это одна из базовых составляющих теории бизнеса Питера Друкера. Теория бизнеса - это совокупность представлений о внешней среде предприятия (о потребителях и их потребностях), о специфической миссии организации (видение) и об ее стержневых компетенциях. Теория бизнеса подлежит постоянному обновлению.

Всеобщее видение должно разделяться всеми или большинством сотрудников организации. Специалисты выделяют такие типы отношения к общему видению: преданный цели, волонтер, согласен в общем, согласен формально, согласен вынужденно, не согласен, апатичен. Для эффективного укрепления в организации теории бизнеса требуется, чтобы большинство сотрудников организации имели отношение к ней первого или второго типа.

Приобщение к общему видению - это добровольный процесс. Заставить быть преданным чему-то невозможно. Следовательно, и общее видение создается всеми сотрудниками, а не только группой руководителей высшего звена. Иными словами, теория бизнеса рождается в процессе повсеместного свободного и открытого диалога внутри организации. Кто-то (руководитель или исполнитель) может выступать в качестве инициатора новой идеи для видения, затем эта идея обсуждается всеми, модифицируется и в конечном итоге вырабатывается общее видение, которое затем и декларируется.

Дисциплина группового обучения означает постоянное обучение совместному действию. Первый навык группового обучения -это умение сочетать диалог и дискуссию. Диалог - это установка на взаимное обогащение участников точками зрения по существу друг друга. Целью же дискуссии является защита, отстаивание какой-то одной точки зрения в процессе критического обсуждения всех точек зрения. Диалог позволяет выявить всю широту имеющихся точек зрения, а дискуссия - посредством совместного критического анализа выбрать из них лучшую. Эффективное групповое обучение требует именно сочетания этих двух форм взаимодействия.

Второй навык дисциплины - это устранение защитных реакций в процессе группового обучения. Защитная реакция проявляется в том, что субъект не высказывает свою истинную точку зрения на проблему, так как остерегается, что другими людьми будет найдена ошибка в его логике рассуждений. Такая модель поведения формируется в детстве и продолжает укореняться в течение жизни. Задача каждого члена группы 
заключается в том, чтобы осознавать появление собственной защитной реакции. Защитная реакция - это сигнал к тому, чтобы подробно проанализировать логику рассуждений, которые субъект пытается скрыть от внешнего взгляда.

Ценность группового обучения заключается в возникновении череды «ментальных синергетических эффектов», когда каждый член группы обогащается в процессе взаимодействия с другими членами группы, а группа в целом, двигаясь в процессе взаимодействия от совокупности разрозненных идей различных ее членов к качественно новому пониманию ситуации. Для того чтобы групповое обучение могло превратиться в дисциплину организации, необходимо найти способы встраивания его в процесс текущей деятельности организации. Проблема встраивания заключается в радикальности связанных с этим изменений управленческой практики.

Таким образом можно сделать вывод о том, что с психологической (бихевиористской) точки зрения основные положения концепции обучающихся организаций П. М. Сенге направлены на создание внутриорганизационных условий возникновения у членов организации потоковых состояний на рабочем месте, то есть полной вовлеченности в процесс труда.

При формировании ССУОЗ, основанной на стратегии персонализации, рекомендуется использовать следующую последовательность действий ${ }^{1}$.

Подготовка (Knowledge Introduction). Определяются ключевые сотрудники, которые реально заинтересованы в поддержании проекта. Они сформируют сообщество, которое в дальнейшем будет продвигать идеи управления организационными знаниями в предпринимательском формировании.

Диагностирование (Knowledge Audit). Оценка ресурсов информации и знаний и их соответствия реальным потребностям сотрудников. Аудит проводится для того, чтобы определить, соответствуют ли внешние источники информации реальным потребностям, насколько эффективно используются знания сотрудников, как осуществляется управление знаниями о клиентах.

Разработка стратегии и политики управления организационными знаниями (Knowledge Strategy and Policy). Проводится анализ полученных ответов и разрабатываются стратегия и тактика управления организационным знанием в субъекте предпринимательства - сценарий и технологические решения; политика управления организационными знаниями, в которой должны быть определены основные механизмы действия программы: какие именно знания особенно важны для компании, что с ними следует делать, как оценивается эффективность обмена знаниями, каковы новые должностные обязанности сотрудников в отношении управления знаниями и т. д.

Реализаџия (Launch Program). Осуществление намеченных планов: вводится в действие политика управления знаниями, меняется содержание входящих информационных потоков, новости из внешних источников при необходимости могут быть «кастомизированы», то есть организованы таким образом, чтобы их напрямую получали заинтересованные сотрудники, составляются директории (каталоги) всех ресурсов, проводятся обучающие программы, внедряются технологические решения, составляются руководства пользователей на новые источники информации и знаний и т.д.

При реализации стратегии кодификации задачи формирования ССУОЗ сводятся к созданию в компании соответствующей инфраструктуры.

С позиций бизнес-инжиниринга, подразумевающего комплексное использование стратегий управления организационными знаниями обоих типов, при формировании

\footnotetext{
${ }_{1}^{1}$ Мариничева М. Управление знаниями: этапы внедрения. URL: http:// bigc.ru/publications/other/km/
} 
ССУОЗ в предпринимательской структуре необходимо решить следующие задачи ${ }^{1}$ :

Идентификаџия деятельности субъекта предпринимательской деятельности на стратегическом и процессном уровне - построение предпринимательской модели хозяйствования. Решение этой задачи способствует выявлению и формализации исключительно важных «стратегических» и «процедурных» знаний - знаний «зачем», «почему» и «как» реализуется деятельность предпринимательской структуры.

Идентификация «ключевых знаний» - создание в предпринимательской модели хозяйствования компании классификаторов «дерево знаний» и «носители ключевого знания», построение «карты знаний» или проекции «дерева знаний» на БД и сотрудников компании. Первичный аудит знаний - анализ элементов знаний и их основных атрибутов, таких как владелец, носитель, использование и достаточность для выполнения действий (покрытие -coverage), определение дефицита знаний (разрывов - gap).

Выбор стратегии управления организационными знаниями -связь ССУОЗ с базовыми принципами предпринимательской деятельности и общей картой стратегий. Идентификация критических факторов успеха и показателей в области управления организационными знаниями. Эта связь реализуется в проработке 4-й перспективы модели Balanced Score Card (BSC).

Связывание «знаний» с процессами предпринимательской деятельности - проекция применения. Введение функций и разработка процессов создания и эффективного управления организационными знаниями в предпринимательскую модель компании, формирование корпоративных регламентов - то есть постановка регулярной деятельности в этой области.

Создание технологической платформы применения знаний (Портал знаний как часть Корпоративного информационного портала, Smart Workflow System - система управления потоками работ -процессами, предоставляющая доступ к нужному знанию в нужных точках процессов) и других поддерживающих систем Support System.

Развитие внутренней культуры обмена знаниями, генерации и применения знаний. Знание, созданное на одном уровне, должно распространяться по другим уровням предпринимательской структуры. Поскольку требования конкурентного окружения и потребителей постоянно меняется, то и процесс создания организационного знания бесконечный и требует постоянных инноваций.

Для повышения конкурентоспособности предпринимательской структуры необходимо кардинально повысить интеллектуальную емкость управленческих действий, для чего потребуются новые управленческие кадры, системы, методы и технологии, а главное -деловая среда, в которой ценностями станут прозрачные экономические отношения, умение генерировать новые идеи, использовать аналитику, выдвигать и обосновывать интеллектуальные новации. Сделать это непросто, а со стороны и вовсе представляется невозможным. Не случайно для решения подобных задач в крупных компаниях создаются собственные научно-учебные центры - корпоративные университеты. В мире их уже более трех тысяч, и стремительный рост продолжается. Наибольшее число корпоративных университетов в США - порядка двух тысяч с достаточно большим годовым бюджетом (7-20 млн дол.). Начался этот процесс и в России (группа «Северсталь», компания «Сухой», оператор сотовой связи «БиЛайн» и др.).

Существующие корпоративные университеты можно условно разделить на две группы: 1) образовательные, которые занимаются в основном обучением персонала; 2) инновационные, ориентированные, прежде всего, на создание и внедрение нового знания, управление организационными знаниями и их применение при разработке новых

\footnotetext{
${ }^{1}$ Менеджмент знаний. URL: http://big.spb.ru/consulting/ consulting_ projects/km/
} 
продуктов и услуг, обучение персонала под новые задачи.

Большинство действующих корпоративных университетов относятся к первой группе. Конечно, они имеют преимущество перед вузами и бизнес-школами благодаря тому, что подстраивают свою работу под проблемы и задачи конкретной компании с учетом корпоративной специфики ${ }^{1}$.

Таким образом, обучение в корпоративных университетах может приносить конкретные результаты только в том случае если оно будет не типовым, а корпоративным, то есть программы рассчитаны специально на конкретную организацию. При этом обучение должно иметь конкретную цель, которая связана с актуальными для компании проблемами и задачами. Проблемы и задачи организации определяет ее руководитель тренер-консультант может только помочь ему в этом. А вот цели обучения и состав участников определяют тренеры (либо, если речь идет о крупных компаниях, - тренеры совместно с HR-менеджером). И если намеченная программа, а точнее ее содержание, не будет противоречить корпоративной культуре организации, то она продвинется вперед в решении своих актуальных проблем и задач.

В зависимости от темпа, в котором предпринимательская структура работает и развивается, устанавливаются сроки и периодичность обучения. Как показывает практика обучающихся организаций, обучение должно проходить не реже, чем один раз в полгода и не чаще, чем один раз в два месяца. При этом состав участников может меняться: один семинар или тренинг проводится для среднего менеджмента, другой - для менеджеров по продажам, третий - для сервисного отдела, четвертый - для учредителей. Получается своеобразное сопровождение в форме семинаров-практикумов. Можно, конечно, и один семинар провести, но организация имеет склонность к инерции и распаду, это ее особенность. Поэтом разовые вливания влияют только на развитие ситуации в ближайшие месяц-два. Развитием организации необходимо заниматься регулярно, как бы все время толкать ее вперед. Два небольших семинара с перерывом в два-четыре месяца будут эффективнее, чем один большой.

Российским условиям, учитывая уникальность, масштаб и глубину преобразований, больше соответствует модель инновационного корпоративного университета (ИнКУ). Внедрение такой модели (рис. 3.13) значительно сложнее, затратнее, требует качественных изменений в организационной культуре, процессах принятия решений, но и эффект несопоставимо выше.

${ }^{1}$ Гительман Л., Исаев А. Корпоративный университет: технологии работы // Журнал Управление Компанией. 2005. № 7 (50). 


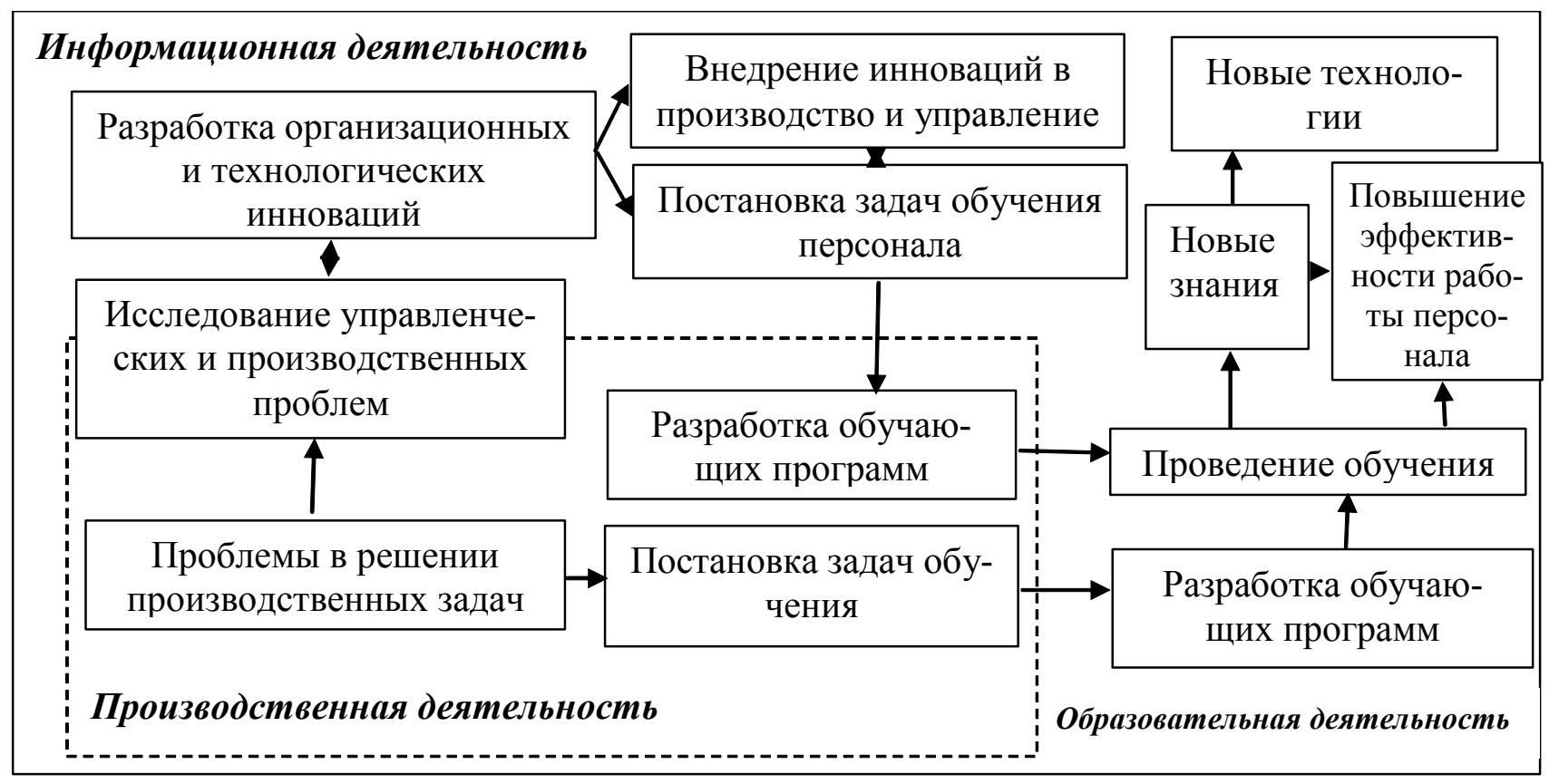

Рис. 3.13. Модель инновационного корпоративного университета

В концепции Л. Гительмана и А. Исаева ИнКУ выделяются следующие элементы: идеология, система целей и задач; условия и этапы создания; технологии; организационная структура ${ }^{1}$.

Идеология ИнКУ заключается в объединении усилий собственника, менеджеров, консультантов по управлению и обучению на основе общей методологии. Авторами разрабатывается такая методология, как интегрированная система консультирования, обучения и преобразующих действий (ИСКО).

Корпоративный университет является той организационной формой, которая обеспечивает своего рода «площадку», инновационную арену. Эта идея в приоритетах задач ИнКУ выражается следующим образом:

- создание стратегии;

- организация инновационного процесса как средства реализации и совершенствования стратегии;

• подбор и обучение персонала для разработки и внедрения инноваций.

Цели и задачи. Главная цель ИнКУ - создание в компании постоянно действующего механизма поддержки инновационной среды. Поэтому основным приоритетом ИнКУ является инновационная деятельность управленческого персонала. Выполняя функцию мозгового центра предпринимательских структур, он занимается научно-прикладными разработками новых видов продукции, совершенствованием управления, производственных технологий, моделей организации новых видов деятельности и в связи с этим -развитием человеческого ресурса (рис. 3.14).

\footnotetext{
${ }^{1}$ Гительжан Л., Исаев А. Указ. соч.
} 


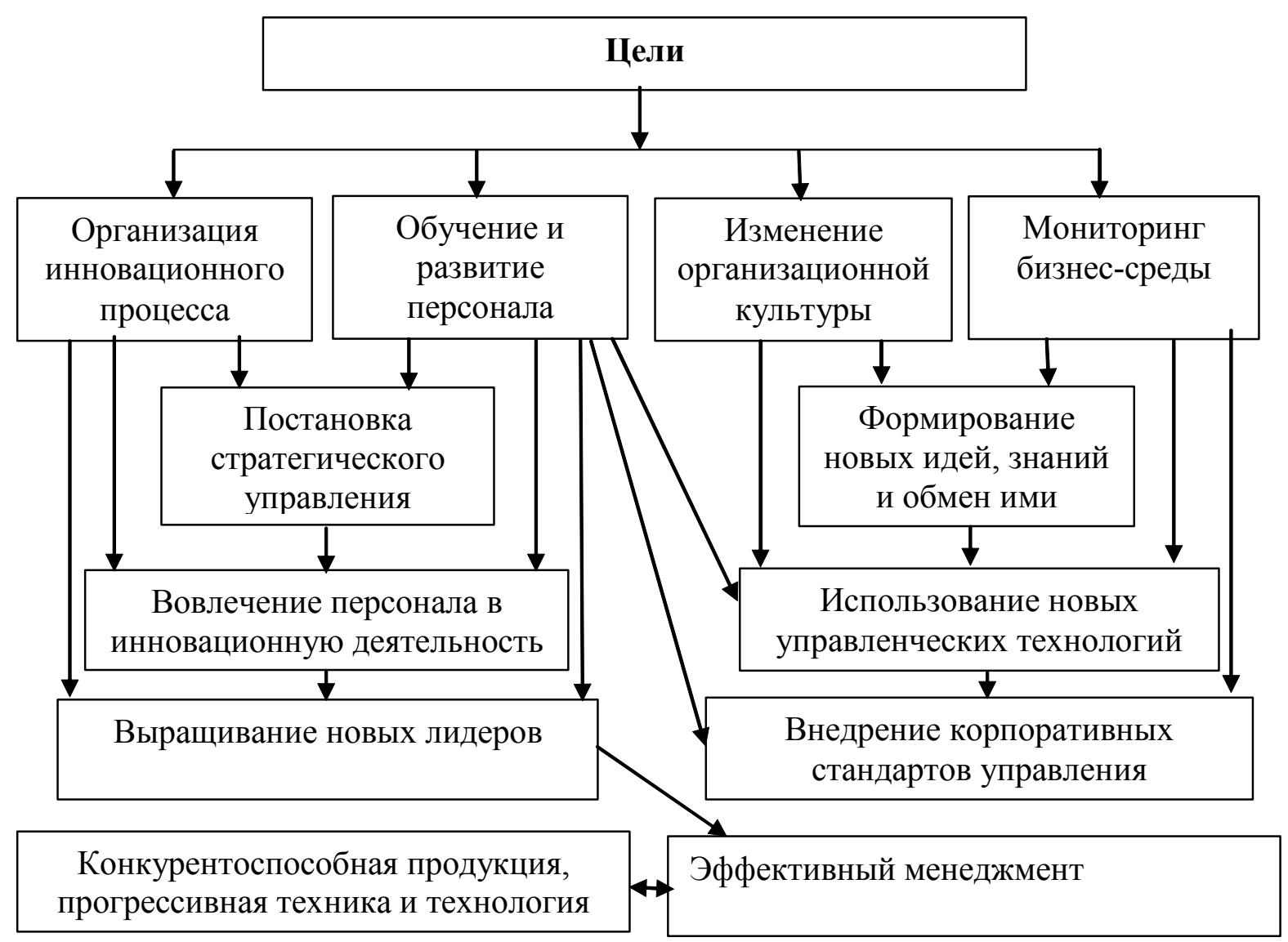

Рисунок 3.14. - Система целей и задач инновационного корпоративного университета

При этом основной акцент делается на совмещение проектирования организационных и технических систем и практического обучения менеджеров и специалистов, которые этим занимаются.

Цели бизнеса определяют задачи инновационной деятельности и приоритеты корпоративного обучения:

- развитие управленческого мышления;

- формирование профессиональных компетенций;

- генерирование новых знаний;

• коррекция организационной культуры компании в соответствии с новой стратегией;

• гибкость и конструктивность ролевого поведения.

Условия и этапь создания. Объективная потребность в корпоративном университете возникает тогда, когда в компании существуют столь серьезные проблемы и реальные трудности в их решении, что руководство не может с ними справиться, используя традиционные методы. Особенно такая потребность ощущается на крупном высокотехнологичном производстве, где постоянно необходимы новые знания, новые образцы сложной продукции, обучение персонала под новые задачи.

Корпоративный университет имеет реальные преимущества перед консалтинговыми фирмами, институтами повышения квалификации и вузами, поскольку:

работает не над типовыми, а над конкретными актуальными проблемами компании; 
подходит к проблемам изнутри и занимается ими постоянно, благодаря чему возникает качественно иной - по сути, генетический - подход, позволяющий рассматривать бизнес-процессы, внешнюю среду, менеджмент в реальной динамике, в развитии;

занимается решением отдельной задачи в комплексе взаимосвязанных вопросов, обеспечивающих перспективу предпринимательских структур в целом;

является объектом и способом инвестирования в развитие интеллектуальной базы конкретной компании и её персонала.

ИнКУ - сложный организм, насыщенный знаниями, технологиями, методиками, и создать его быстро нельзя. Процесс становления ИнКУ состоит из многих этапов, основными из которых являются: подготовительный; внедрения и отладки; совершенствования и развития. На каждом этапе реализуются конкретные задачи, имеющие специфическое содержание и предполагающие определенную последовательность действий.

Для формирования инновационного процесса, являющегося основой создания знания, очень важно, чтобы методы управления инновационным процессом и внутрифирменным обучением было органично встроено в производственный процесс. Безусловно, на конечный результат определяющее значение будет иметь эффективность принимаемых управленческих решений. 


\section{Г л а в а 4 \\ ОРГАНИЗАЦИОННО-ЭКОНОМИЧЕСКИЙ МЕХАНИЗМ \\ ФОРМИРОВАНИЯ ССУОЗ СУБЬЕКТА \\ ПРЕДПРИНИМАТЕЛЬСТВА}

\section{1. ЭФФЕКТИВНОСТЬ УПРАВЛЕНЧЕСКИХ РЕШЕНИЙ И РОЛЬ ИНФОРМАЦИОННОЙ ИНФРАСТРУКТУРЫ В СИСТЕМЕ СОЗДАНИЯ И ЭФФЕКТИВНОГО УПРАВЛЕНИЯ ОРГАНИЗАЦИОННЫМ ЗНАНИЕМ}

Критерием оценки принимаемых управленческих решений является эффективность. Если два образа действий предполагают одинаковые издержки, предпочесть следует тот, который дает наивысшие результаты.

В экономической науке и практике под эффективностью (эффект - лam. effectus исполнение, действие) понимается результативность, интенсивность функционирований системы, уровень результативности в сопоставлении с производственными затратами, степень достижения цели, степень соответствия цели социально-экономическим потребностям фирмы, качество управления и прочее, что свидетельствует о сложности представления данной категории в конкретных показателях, измерениях, оценках ${ }^{1}$.

Эффективность функционирования управления как совокупности управляемой и управляющей систем зависит от оптимальности принятых решений, качества результатов ее деятельности, скорости принятия решений и обмена информацией, скорости и качества реализации управленческих решений и рекомендаций, (то есть в объекте управления), с одной стороны, и использование производственно-технического потенциала в реализации инвестпрограмм (субъект управления) с другой.

Эффективность управленческих решений характеризует качество обменных процессов между организацией и ее внешней средой, так как организация и внешняя среда находятся в процессе постоянного информационного обмена; процессов привлечения ресурсов, их трансформации в готовые продукты, услуги и распределение во внешней среде. Чем выше качество этих процессов, тем выше эффективность управленческих решений.

Современные тенденции глобализации на основе информатизации и информационных технологий способствуют интенсификации конкурентной среды и необходимости формирования стратегических конкурентных преимуществ на основе маркетинговой концепции разработки экономической политики организации. Поэтому под эффективностью системы управления организацией в современных условиях «нестационарной» рыночной экономики понимается рост потенциала организации, рост добавленной стоимости, рост стоимости компании, увеличение доли рынка, увеличение объема продаж, снижение издержек и т. д. Конкретное содержание этой категории зависит от особенностей организации, где оценивается эффективность принимаемой экономической политики, ее целей и технологий достижения целей.

${ }^{1}$ Асаул А. Н. Организация предпринимательской деятельности. СПб.: Питер, 2005; Виханский О. C, Наумов А. И. Менеджмент: учебник. 3-е изд. М.: Гардарика, 1998. 


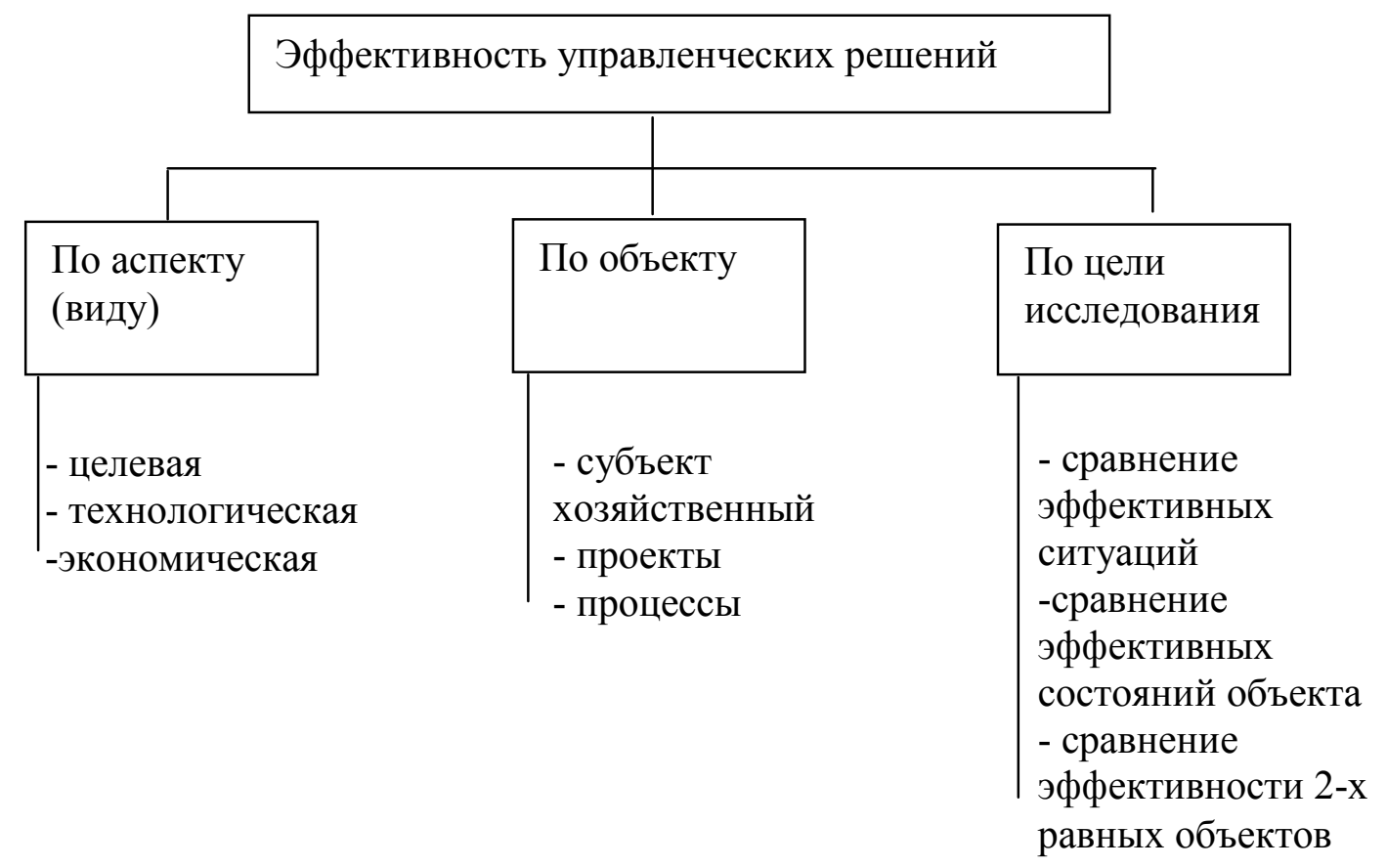

Рис. 4.1. Типология методических подходов к оценке эффективности экономической политики компании

Методологический подход к исследованию какого-либо экономического явления или категории базируется на некоторых принципах, правилах конструирования, присущих данной категории. Так для конкретизации понятия эффективность управленческих решений часто используют три концептуальных подхода к определению эффективности: по виду (аспекту), объекту и цели исследования (рис. 4.1) ${ }^{1}$. По виду (аспекту) обычно различаются целевая (функциональная), технологическая (ресурсная) и экономическая эффективность. Под целевой эффективностью понимается степень соответствия функционирования системы ее целевому назначению, при этом следует учитывать, что эффективность зависит не только от степени достижения целей экономической политики организации как генеральных целей, так и целей ее функциональных составляющих: инновационно-инвестиционной, товарно-ассортиментной, снабженческо-сбытовой, организационно-управленческой, но и от качества самих целей, поскольку поставленные цели могут быть изначально недостижимыми, не соответствовать рыночным реалиям экономики и т. п.

Следует заметить, что целевая (функциональная) эффективность может применяться к так называемым целенаправленным системам, то есть к системам, имеющим признанные обществом цели или функции, к системам, для которых имеет смысл понятия затраты $\longrightarrow$ результаты $\longrightarrow$ цели, так как существует процесс достижения цели в виде получения (генерации) результатов с помощью затрат ресурсов.

Технологическая (ресурсная) эффективность - это степень интенсивности использования ресурсов организации с точки зрения соотношения между объемами, издержками и размерами затраченных ресурсов.

Высокая способность получать и использовать ресурсы важна только в том случае,

${ }^{1}$ Асаул А. Н,, Князь И. П., Коротаева Ю. В. Теория и практика принятия решений по выходу организаций из кризиса / под ред. А. Н. Асаула. СПб.: АНО ИПЭВ, 2007. 
если ресурсы и возможности компании используются для получения результата, соответствующего потребностям внешней среды. Использование ресурсного подхода является более оправданным для компаний на стабильном рынке, он не обеспечивает адекватную оценку при изменении ситуации и нужд потребителей ${ }^{1}$. Для измерения технологической эффективности используется ряд коэффициентов индексов. Технологическая (ресурсная) эффективность характеризует эффективность организационно-управленческих инноваций вне связи с количеством использующихся ресурсов и может изменяться только при изменении технологии бизнес-процессов.

При подходе с учетом внутренних бизнес-процессов эффективность оценивается по экономичности управления и не учитывает изменение состояния внешней среды. Эффективность организационно-управленческой инновации с позиции данного подхода это экономичность цепочки создания ценности для потребителя/клиента. Процессный подход также имеет ограничения своего использования: он не всегда учитывает общий результат деятельности компании, поскольку многие аспекты внешних воздействий и внутренних процессов нельзя представить количественно.

Экономическая эффективность представляет соотношение результатов и затрат. К полученным результатам относят прибыль, добавленную стоимость, объем продаж и т. п., рассчитываемые с учетом складывающихся реальных цен.

Эффективность деятельности предпринимательской структуры - это свойство, связанное с ее способностью в рамках нормативной системы общественных ценностей формулировать и достигать цели в соответствии с предъявляемыми потребностями в виде результатов, соотнесенных с затратами, путем использования соответствующих средств и с учетом факторов-условий ее функционирования ${ }^{2}$.

Второй методологический подход к определению экономической эффективности управленческих решений основывается на понятии эффективности с точки зрения возможных объектов исследования. К объектам эффективности относятся: 1) самостоятельные организации; объединения, ассоциации, сетевые структуры; рынки (совокупность потенциальных и реальных производителей, потребителей товаров и услуг и пр.; 2) проекты (планируемые мероприятия, осуществляемые организацией; 3) процессы (понимаемые как последовательная смена состояний системы).

При любом выборе объекта анализ эффективности опирается на ту же схему, что и в случае целевой эффективности: затраты $>$ результаты $>$ цели (организации). Методологический подход к оценке эффективности объектов, проектов и процессов называется трансакционным (трансакция - акт приобретения некоторого блага (результата) в обмен на деньги (затраты) в дискретном времени.

Третий подход к оценке социально-экономической эффективности управленческих решений (рис. 4.2) основывается на целях исследования эффективности управленческих решений и имеет отличительную особенность от ранее рассмотренных - сравнительный характер. При этом возможны следующие варианты сравнений: целью исследования эффективности является сравнение двух ситуаций (ситуационный, сценарный подходы); целью исследования эффективности является состояние одного и того же объекта в разные периоды времени; целью исследования является состояние двух разных объектов.

К результатам управленческих решений относятся: качество решения, обеспеченность, степень разнообразия, степень соответствия целям критериям

1 Национальный доклад «Организационно-управленческие инновации: развитие экономики, основанной на знаниях» / под ред. С. Е. Литовченко. М.: Ассоциация Менеджеров, 2008.

${ }^{2}$ Модернизация экономики на основе технологических инноваций / А. Н. Асаул и др. СПб: АНО ИПЭВ, 2008. 
требованиям заказчика, а также устойчивость, точность, внутренняя непротиворечивость (согласованность), возможность развития, степень усовершенствования процедуры принятия решения.

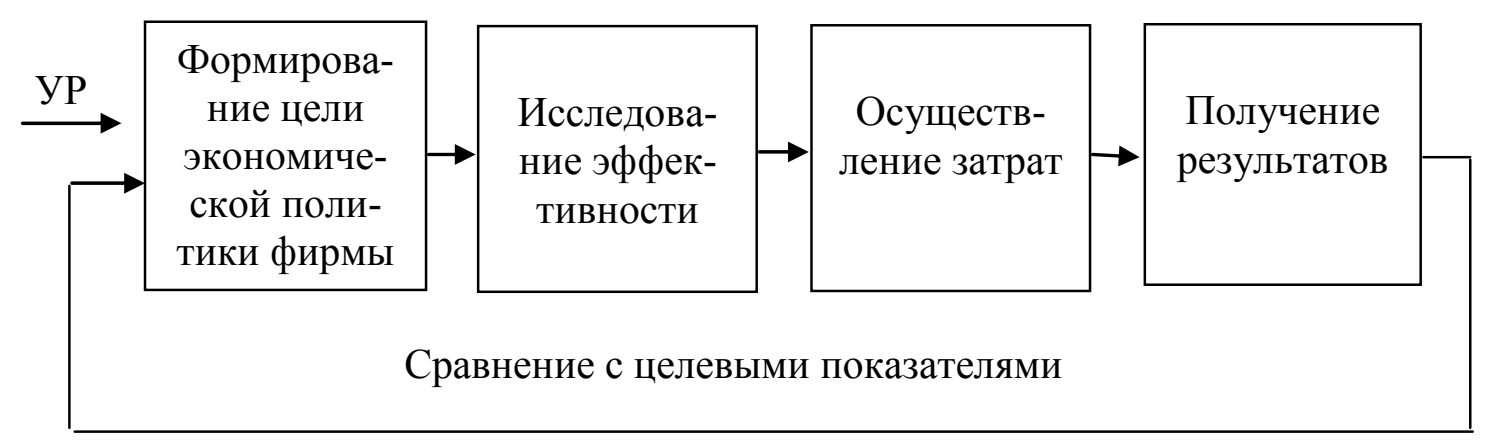

Рис. 4.2. Процесс оценки экономической эффективности управленческих решений

Многообразие факторов результативности инноваций в управлении (табл. 4.1) усложняет механизм оценки результатов организационных изменений, в котором можно выделить три основных блока: измерение результата; оценка показателей эффективности и анализ (интерпретация) полученных оценок.

\section{Факторы результативности организационно-управленческих инноваций}

\begin{tabular}{|c|c|c|}
\hline $\begin{array}{l}\text { Факторы, } \\
\text { новаторство }\end{array}$ & $\begin{array}{l}\text { Факторы, поддерживающие } \\
\text { новаторство }\end{array}$ & $\begin{array}{l}\text { Факторы, } \\
\text { новаторство }\end{array}$ \\
\hline $\begin{array}{l}\text { Недоверие руководителей } \\
\text { к выдвигаемым «снизу» } \\
\text { новым идеям }\end{array}$ & $\begin{array}{lr}\text { Поддержка } & \text { новаторов со } \\
\text { стороны } & \text { высшего } \\
\text { руководства } & \end{array}$ & $\begin{array}{l}\text { Поддержание } \\
\text { работников } \\
\text { учиться и помления } \\
\text { квалификациюстоянать свою } \\
\end{array}$ \\
\hline $\begin{array}{l}\text { Создание } \quad \text { жестких } \\
\text { механизмов контроля за } \\
\text { деятельностью новаторов }\end{array}$ & $\begin{array}{l}\text { Предоставление новаторам } \\
\text { необходимой свободы при } \\
\text { разработке новшеств }\end{array}$ & $\begin{array}{l}\text { Сочетание } \\
\text { образования }\end{array}$ \\
\hline $\begin{array}{l}\text { Вмешательство } \\
\text { несопряженных } \\
\text { структурных } \\
\text { подразделений в оценку } \\
\text { новаторских предложений }\end{array}$ & $\begin{array}{l}\text { Поддержание эффективных } \\
\text { коммуникаций с коллегами, } \\
\text { другими подразделениями и } \\
\text { компаниями }\end{array}$ & 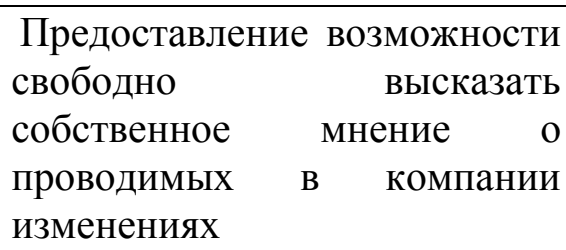 \\
\hline 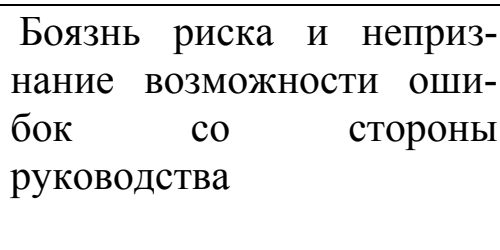 & $\begin{array}{lr}\text { Высокое } & \text { доверие } \\
\text { стороны } & \text { руководства } \\
\text { компании и } & \text { допущение } \\
\text { возможности } & \text { поисковых } \\
\text { ошибок } & \end{array}$ & $\begin{array}{l}\text { Преодоление барьеров и } \\
\text { «размывание границ» между } \\
\text { разными видами работ и } \\
\text { функциональными } \\
\text { обязанностями }\end{array}$ \\
\hline $\begin{array}{l}\text { Незамедлительная крити- } \\
\text { ка и угрозы увольнения в } \\
\text { связи с } \quad \text { допущением } \\
\text { ошибок в } \text { в процессе } \\
\text { новаторской деятельности }\end{array}$ & $\begin{array}{l}\text { Ведение дискуссий и обмен } \\
\text { идеями без страха наказания }\end{array}$ & $\begin{array}{l}\text { Предоставление } \\
\text { содержательной } \\
\text { информация, дамом } \\
\text { негативна }\end{array}$ \\
\hline
\end{tabular}




\begin{tabular}{|c|c|c|}
\hline \begin{tabular}{|llr} 
Строгое & наказание \\
просчеты & в & творческом \\
поиске & &
\end{tabular} & $\begin{array}{l}\text { Отсутствие } \\
\text { наказания за просчого } \\
\text { творческом поиске }\end{array}$ & $\begin{array}{l}\text { Проведение } \\
\text { совещаний рабочих групп }\end{array}$ \\
\hline $\begin{array}{l}\text { Создание стереотипов } \\
\text { мышления в компании }\end{array}$ & $\begin{array}{ccc}\text { Создание } & \text { в } & \text { компании } \\
\text { атмосферы взаимопонимания }\end{array}$ & \begin{tabular}{|lc}
\multicolumn{1}{|c}{ Логичная } & \multicolumn{1}{c}{ аргументация } \\
необходимости & изменений \\
реорганизаций в компании
\end{tabular} \\
\hline $\begin{array}{l}\text { Строгое выполнение сво- } \\
\text { их функциональных обязан- } \\
\text { ностей новатором, полный } \\
\text { запрет на несанкциони- } \\
\text { рованный поиск } \\
\end{array}$ & $\begin{array}{l}\text { Приоритет разнообразия и } \\
\text { творчества над однообразием } \\
\text { и приспособленчеством }\end{array}$ & $\begin{array}{l}\text { Предоставление } \\
\text { условий и режимов труда }\end{array}$ \\
\hline $\begin{array}{l}\text { Тенденции к излишнему } \\
\text { сужению границ предмета } \\
\text { исследования новаторами }\end{array}$ & \begin{tabular}{|c} 
Свободный доступ к \\
дополнительным источникам \\
информации о нововведениях
\end{tabular} & $\begin{array}{l}\text { Использование альтернатив- } \\
\text { ных форм трудового процесса } \\
\text { для новаторов }\end{array}$ \\
\hline $\begin{array}{l}\text { Необходимость множества } \\
\text { согласований по разработке } \\
\text { и внедрению новых идей }\end{array}$ & \begin{tabular}{|cc} 
Уменьшение помех \\
мелочного вмешательства \\
выполнение работ новатором
\end{tabular} & \begin{tabular}{|lrr}
\multicolumn{2}{|c}{ Использование } & различных \\
рычагов & и & стимулов \\
активизации & & новаторской \\
деятельности & \\
\end{tabular} \\
\hline $\begin{array}{l}\text { Постановка задач } \\
\text { новаторам и передача им } \\
\text { информации, } \\
\text { сопровождаемая угрозами } \\
\text { со стороны руководителя }\end{array}$ & \begin{tabular}{|l} 
Повышение \\
восприимчивости \\
менеджмента к новым идеям
\end{tabular} & 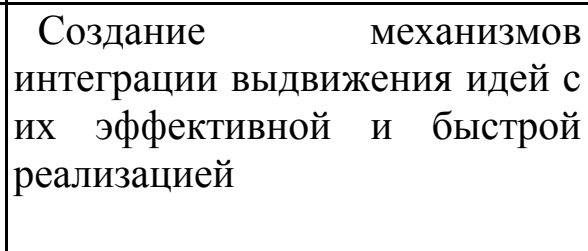 \\
\hline \begin{tabular}{|lr}
\multicolumn{2}{|c}{ Возникновение } \\
шестоящих & руководителей \\
«синдрома & всезнающих \\
экспертов» & \\
\end{tabular} & $\begin{array}{l}\text { Делегирование } \\
\text { самоуправления в творческий } \\
\text { процесс }\end{array}$ & \begin{tabular}{|lr} 
Создание духа предприим- \\
чивости, распространение его \\
на рядовых \\
компании
\end{tabular} \\
\hline $\begin{array}{l}\text { В случае использования } \\
\text { неэффективного нововве- } \\
\text { дения обвинение новатора в } \\
\text { неудаче }\end{array}$ & $\mid$\begin{tabular}{ll}
\multicolumn{2}{|c}{ Признание } \\
вклада $\quad$ позитивного \\
деятельность компании
\end{tabular} & $\begin{array}{l}\text { Обучение } \\
\text { способам } \\
\text { мышления }\end{array}$ \\
\hline \begin{tabular}{|lr} 
Строгая & временная \\
регламентация & выполнения \\
работ новатором
\end{tabular} & \begin{tabular}{|l} 
Выделение \\
дополнительного времени \\
для «вызревания идей»
\end{tabular} & \begin{tabular}{|lr}
\multicolumn{1}{|c}{ Постоянная } & \multicolumn{2}{c}{ поддержка } \\
атмосферы & доверия и \\
восприимчивости к переменам
\end{tabular} \\
\hline \begin{tabular}{|lr} 
Недопущение & к \\
использованию & новатором \\
необходимых & видов \\
ресурсов & \\
\end{tabular} & $\begin{array}{c}\text { Обеспечение } \\
\text { необходимыми ресурсами и } \\
\text { оборудованием }\end{array}$ & $\begin{array}{l}\text { Поощрение } \\
\text { профессий }\end{array}$ \\
\hline
\end{tabular}

Таким образом, оценка эффективности организационно-управленческих инноваций, к которым относится и управление организационным знанием, может включать следующую последовательность действий руководителя компании: компании;

- определить реальные полезные результаты, которые должны быть получены в

- обозначить ограничения - например, интервал времени для получения эффекта от нового знания или объем выделенных ресурсов на внедрение нового знания;

- определить степень соответствия получаемого эффекта от нового знания желаемым значениям;

К затратам управленческих решений относятся информационные затраты, 
временные затраты, технические затраты, трудовые ресурсы и прочие затраты.

Эффективность - это соизмерение ресурсов (затрат), необходимых для достижения результатов. Основными факторами эффективности решений являются три группы факторов: использование ресурсов, фактор времени и целенаправленность управления.

Первый фактор характеризует структуру, качество ресурсов, их экономию в процессах управления и возможность пополнения и накопления. Второй - отражает своевременность решений, экономию времени, использование новых технологий и потенциал персонала, способного решать проблемы достаточно оперативно и профессионально.

Третий фактор отражает реальность и значительность цели, в соответствии с которой и рассматривается результат деятельности менеджера, его стратегия, учет рыночных процессов экономического развития.

Интенсивность представляет собой соизмерение усилий и времени, производительность - результата и времени.

Сравнение фактической отдачи осуществляемого управленческого решения с ожидаемой предполагает эффективность или результативность решения. Выполняя данную работу, необходимо добиваться того, чтобы окончательная формулировка решения отражала механизм измерения его эффективности. Если невозможно определить и измерить эффективность решения, рекомендуется избегать его утверждения, так как, видимо, неверно определены его переменные в процессе анализа проблемы. Решение эффективно, если оно способствует приближению к поставленной цели. В случае же многоцелевой деятельности эффективным можно считать решение, при котором достигается положительный результат и оно превалирует над некоторыми второстепенными целями ${ }^{1}$.

Методы измерения эффективности должны соответствовать целям экономической политики и ее принципам, а также технологиям их осуществления. В настоящее время можно выделить следующие шесть основных методов измерения эффективности управленческих решений.

1. Метод сравнения фактических / нормативньх затрат и результатов основан на сравнении до и после осуществления управленческих технологий.

2.Индексный метод основан на относительных показателях, выражающих отношение уровня показателей до и после осуществления управленческих технологий.

3. Методы оценки инноваџионно-инвестищионных проектов подразумевают, что объектом исследования эффективности являются мероприятия, связанные с внедрением инновационных технологий. При этом «инновационная технология» трактуется достаточно широко - как комплекс нового оборудования, соответственно технологий (в инженерном смысле), организационно-экономических инноваций и т. д., которые в совокупности позволяют произвести принципиально новый продукт либо осуществить выпуск традиционного продукта с меньшими совокупными затратами или с повышением его качества. Не исключает это понятие и получение результатов внеэкономического характера (экологического, социального и т. д.), если применение нового знания в основном (или дополнительно) ориентировано на достижение этих целей.

4. Методы учета рисков.

5. Метод оценки стратегичности (метод паутины).

6. Метод учета конкурентоустойчивости.

Переход к оценке эффективности инноваций во всех перечисленных ситуациях (экономических системах) идентичен: абсолютная эффективность оценивается путем

\footnotetext{
${ }^{1}$ Саиков Н. Я. Практический менеджмент / URL: http://enbv.narod.ru
} 
сопоставления всех связанных с данным вариантом инноваций совокупных результатов и затрат за весь жизненный цикл действия новшеств, а выбор наилучшего из альтернативных вариантов инноваций производится на основе максимизации ожидаемого эффекта (разности оценок совокупных результатов и затрат). Однако конкретные алгоритмы реализации указанных положений, методов расчета сопоставляемых величин результатов и затрат, отражения в них основных влияющих факторов и т. д. могут существенно различаться.

Чтобы иметь возможность эффективно использовать новые организационные знания, менеджмент предпринимательской структуры должен определить критерии, на основании которых отбираются, анализируются и оцениваются новые знания. Такие критерии могут иметь вид экономических расчетов, а также показателей результативности управления. Экономические расчеты управленческого эффекта возможны в том случае, если результат инновации в сфере управления может быть измерен прямым счетом в натуральных или денежных единицах с учетом необходимых или произведенных затрат ресурсов (средств), а также временных ограничений. Вместе с тем, не все результаты управления знанием могут быть измерены прямым счетом. Но управленческий эффект может быть оценен мерой вклада усилий субъекта управления в изменение параметров процессов создания стоимости. Конкуренция объективно вынуждает повышать качество и эффективность управленческого решения. Поэтому в настоящее время наблюдается тенденция увеличения количества учитываемых условий повышения качества и эффективности решений на основе автоматизации системы менеджмента ${ }^{1}$.

Информационные средства, так или иначе связанные с управлением знаниями, принято делить на технологии интеллекта бизнеса (Business intelligence) и технологии управления знаниями (Knowledge management).

Интеллект бизнеса - это знания о бизнесе, добытые с использованием различных аппаратно-программных технологий. Такие технологии дают предприятиям возможность превращать данные в информацию, а затем информацию в знания. Эти технологии предназначены для организации доступа и обработки так называемых структурированных данных, то есть данных, которые можно легко классифицировать по определенным атрибутам - имя, индекс, номер трансакции и т. д. - и упорядочить на этой основе.

Неструктурированные данные обычно хранятся в форме, не позволяющей осуществить простую и логическую классификацию -тексты, контракты, презентации, фотографии, видеоролики и др. Для работы с такими данными предложены различные технологии управления знаниями, которые призваны сделать знания доступными и повторно используемыми в масштабах всей корпорации.

Указанные категории информационных технологий включают следующие инструменты ${ }^{2}$ :

- базы знаний и хранилища данных и знаний;

- оперативная и интеллектуальная обработка данных;

- средства управления документами, контентом и электронной почтой;

- средства управления внешними информационными потоками;

- средства коллективной работы;

• комплексные средства управления знаниями: платформы управления знаниями и корпоративные порталы знаний;

- средства, поддерживающие принятие решений: системы, поддерживающие

1 Асаул А. Н,, Батрак А. В. Корпоративные структуры в региональном инвестиционностроительном комплексе. М.: АСВ; СПб.: СПбГАСУ, 2001.

${ }^{2}$ Управление знаниями в корпорациях / Б. 3. Мильнер и др. М.: Дело, 2006. 
дискуссионные группы, экспертные системы и др.

Базы и хранилища данных, базы знаний. Традиционные средства извлечения информации из баз данных в виде систем оперативной обработки трансакций (online transaction processing - OLTP) создавались для автоматизации рутинных операций: выписки счетов, оформления договоров, проверки состояния склада и т. д. - и предназначались в основном для линейного персонала. Однако для менеджеров и аналитиков актуальна задача более глубокой обработки большего объема данных. Для решения этих задач создаются специализированные среды хранения данных, называемые хранилищами данных (ХД). Они отличаются от традиционных баз данных тем, что проектируются для поддержки процессов принятия решений, а не просто для эффективного сбора и обработки данных. Как правило, хранилище содержит многолетние версии обычной базы данных, физически размещаемые в той же самой базе. В ХД обычно входят следующие виды данных: текущие детальные данные, хронологические (архивные) данные, слабообобщенные данные и метаданные (репозитарий).

Концептуально модель хранилища данных можно представить в виде схемы (рис. $4.3)$.

Данные из различных источников помещаются в хранилище, а их описания - в репозитарий метаданных. Конечный пользователь, используя различные инструменты (средства визуализации, построения отчетов, статистической обработки и т.д.) и содержимое репозитария, анализирует данные в хранилище. Результатом является информация в виде готовых отчетов, найденных скрытых закономерностей, каких-либо прогнозов.

Хранилища данных обеспечивают аналитикам, управленцам и руководителям высшего звена возможность изучать большие объемы взаимосвязанных данных при помощи быстрого интерактивного отображения информации на разных уровнях детализации в соответствии с представлениями пользователя о предметном пространстве.

Для более значительной поддержки процесса принятия решений проектируются базы знаний, включающие в себя знания сотрудников предпринимательских структур. Основная цель такой базы знаний - сохранить созданные сотрудниками ценные знания для последующего их использования.

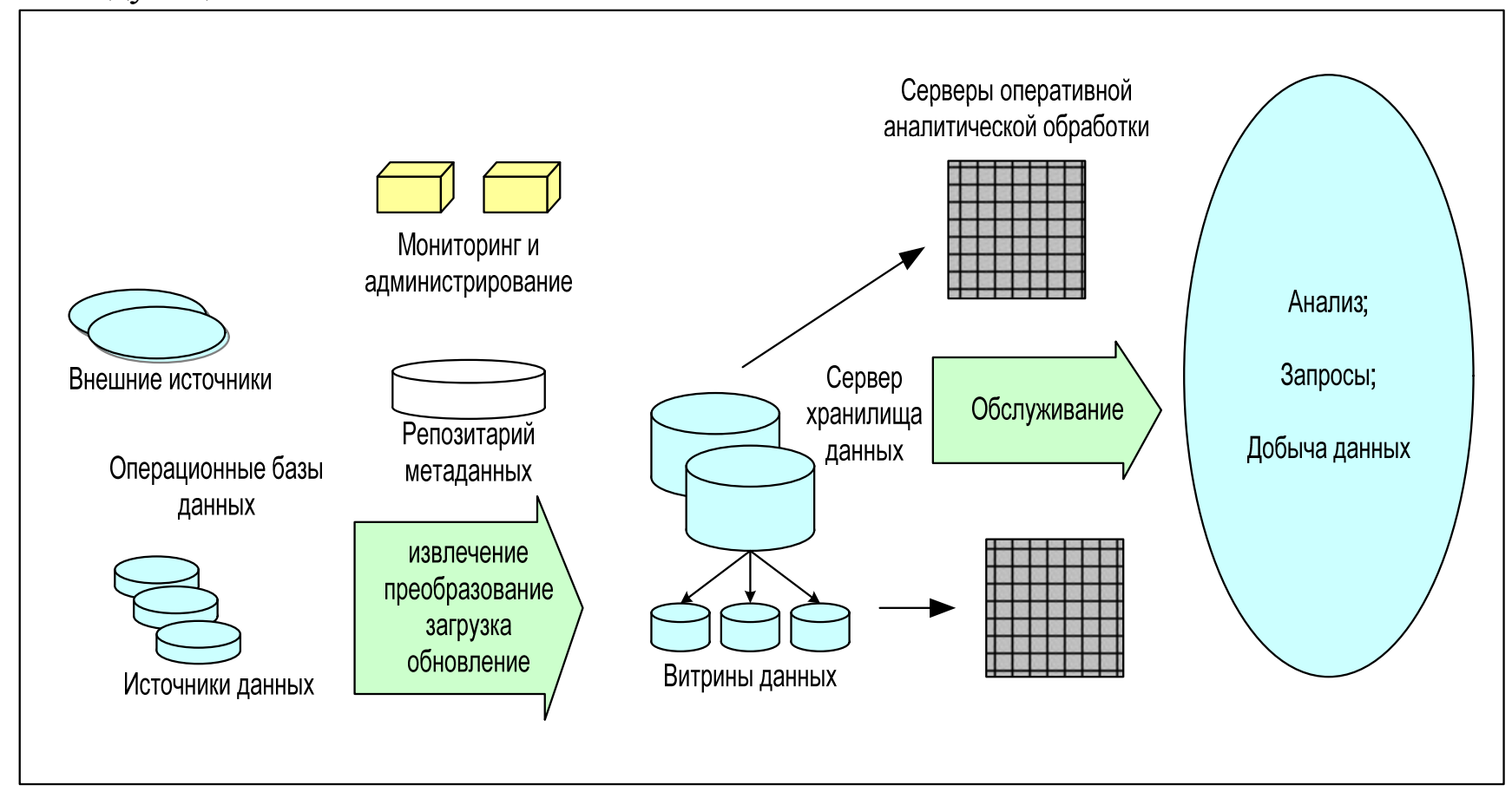

Рис. 4.3. Модель хранилища данных 
Для обеспечения процесса обслуживания применяются стационарные и динамические решения. Стационарные решения связаны с сохранением, наращиванием и обновлением базы знаний. Динамические ориентированы на управление потоками знаний. Здесь можно выделить «навязывание» знаний персоналу под конкретную ситуацию, возникающую у менеджера; «разведку» знаний и их обработку для поддержки будущих решений; обеспечение инициативного доступа персонала к базе знаний; поиск комплекса поддерживающих знаний под конкретное задание («вытягивание» знаний). знания ${ }^{1}$ :

При создании баз знаний могут использоваться следующие методы организации

1. Логическая модель представления знаний - вся информация, необходимая для решения прикладных задач, рассматривается как совокупность фактов и утверждений, которые представляются как формулы в некоторой логике. Знания отображаются совокупностью таких формул, а получение новых знаний сводится к реализации процедур логического вывода. Основным достоинством этого способа организации знаний является то, что разработаны достаточно эффективные процедуры вывода, позволяющие хранить в базе знаний лишь множество аксиом, а все остальные знания получать из них по правилам вывода.

2. Семантическая сеть - информационная модель предметной области, имеющая вид ориентированного графа, вершины которого соответствуют объектам предметной области, а дуги (рёбра) задают отношения между ними. Объектами могут быть понятия, события, свойства, процессы.

В сжатом виде принципы построения баз знаний и управления ими можно представить следующим образом²:

1. Постоянный сбор информации.

2. Обработка помещаемой в базу знаний информации.

3. Постоянное обновление информации и знаний.

4. Использование, желательно повсеместное, информации и знаний базы в практической деятельности (крайне важен баланс между соблюдением третьего и четвертого принципов).

Оперативная аналитическая обработка данных (Online Alanytical Processing OLAP) - это класс программного обеспечения, дающий пользователю возможность в режиме реального времени получать ответы на произвольные аналитические запросы. В основе OLAP лежит понятие многомерного куба данных, в ячейках которого хранятся анализируемые (числовые) данные, например, об объемах продаж. Осями многомерной системы координат служат основные атрибуты анализируемого бизнес-процесса, например названия товаров и месяцев года. В простейшем случае двумерного куба (квадрата) получаем таблицу, показывающую значения уровней продаж по товарам и месяцам. Дальнейшее усложнение модели данных может идти по нескольким направлениям ${ }^{3}$ :

- увеличение числа измерений - данные о продажах не только по месяцам и товарам, но и по регионам (в этом случае куб становится трехмерным);

- усложнение содержимого ячейки - в каждой ячейке содержатся разнообразные данные;

${ }^{1}$ Гаврилова Т. А. Извлечение и структурирование знаний для экономических систем. М., 1992.

${ }^{2}$ Харрингтон Дж,, Воул Ф. Совершенство управления знаниями. М.: РИА «Стандарты и качество», 2008

${ }^{3}$ Мильнер Б. 3. и др. Указ. соч. 
• введение иерархии в пределах одного измерения - например, деление общей выручки на выручку подразделений;

Таким образом, являясь одним из способов добычи и анализа данных, OLAP предоставляет пользователю естественную, интуитивно понятную модель данных.

Интеллектуальный анализ данных (ИАД; Knowledge Discovery in Databases) технология извлечения новых знаний из хранилищ данных путем выявления закономерностей в накопленной информации. Выделяют следующие процессы ИАД:

- поиск зависимостей, состоящий в просмотре базы данных для автоматического выявления зависимостей;

- прогнозирование, предполагающее, что пользователь может предъявить системе записи с незаполненными полями и запросить недостающие значения. Система проанализирует содержимое базы и сделает правдоподобное предсказание относительно этих значений;

- анализ аномалий - процесс поиска нетипичных данных, сильно отклоняющихся от устойчивых зависимостей.

Системы ИАД применяются в научных исследованиях и образовании, в работе правоохранительных органов, производстве, здравоохранении и многих других областях. Особенно широко технология ИАД используется в деловых приложениях.

В основу технологии ИАД положен не один подход, а несколько принципиально различных подходов, причем использование некоторых из них невозможно без специальной подготовки. Выбор подхода нередко требует привлечения специалиста по ИАД.

Получение данных включает итеративно создаваемые модели на основе подготовленного множества данных, а затем применение одной или нескольких моделей. Поскольку создание моделей на больших множествах данных может оказаться весьма дорогостоящим, аналитики часто сначала работают с несколькими выборками множества данных.

Интеллектуальный анализ данных состоит из следующих этапов:

1. Подготовка исходного набора данных.

2. Практически всегда требующаяся дополнительная предобработка данных. Данные могут содержать пропуски, шумы, аномальные значения и т. д., которые требуется исключить. Кроме того, данные могут быть избыточны, недостаточны и т. д. В некоторых задачах требуется дополнить данные некоторой априорной информацией. Они должны быть качественны и корректны с точки зрения используемого метода. Более того, иногда размерность исходного пространства может быть очень большой, и тогда желательно применение специальных алгоритмов понижения размерности.

3. Трансформация, нормализация данных. Этот этап необходим для тех методов, которые требуют, чтобы исходные данные были в каком-то определенном виде.

4. Data Mining. На этом этапе применяются различные алгоритмы для нахождения знаний: нейронные сети, деревья решений, алгоритмы кластеризации и установления ассоциаций и т. д.

5. Постобработка данных. Это интерпретация результатов и применение полученных знаний в бизнес-приложениях.

Data Mining - процесс обнаружения в исходных данных ранее неизвестных, нетривиальных, практически полезных и доступных интерпретации знаний, необходимых для принятия решений в различных сферах человеческой деятельности. Методами Data Mining являются ${ }^{1}$ :

1 Управление знаниями в корпорациях / Б. 3. Мильнер и др.; Харрингтон Дж,, Воул Ф. 
1. Нейронные сети - это большой класс систем, архитектура которых имеет аналогию с построением нервной ткани из нейронов. Нейросетевые технологии предоставляют сегодня широкие возможности для решения задач прогнозирования, обработки сигналов и распознавания образов. По сравнению с традиционными методами математической статистики, классификации и аппроксимации эти технологии обеспечивают достаточно высокое качество решений при меньших затратах. Они позволяют выявлять нелинейные закономерности в сильно зашумленных неоднородных данных, дают хорошие результаты при большом числе входных параметров и обеспечивают адекватные решения при относительно небольших объемах данных.

2. «Деревья решений» - этот метод заключается в создании иерархической структуры классифицирующих правил типа «если... то...» (if - then), имеющую вид дерева. Для принятия решения, к какому классу отнести объект или ситуацию, требуется ответить на вопросы, стоящие в узлах этого дерева, начиная с его корня. Вопросы имеют вид: «Значение параметра $A$ больше Х?» Если ответ положительный, осуществляется переход к правому узлу следующего уровня, если отрицательный - к левому узлу; затем снова следует вопрос, связанный с соответствующим узлом.

3. Индукция правил - этот метод осуществляется путем генерации неполных деревьев решений, а для того чтобы выбрать, какое из них будет применено к входным данным, используются статистические методы.

Типовыми задачами интеллектуального анализа данных являются: прогнозирование, маркетинговый анализ, анализ работы персонала, анализ эффективности продаж, профилирование клиентов, оценка потенциальных клиентов, анализ результатов маркетинговых исследований, анализ работы региональных отделений компании, сравнительный анализ конкурирующих фирм.

Средства управления содержанием предпринимательской структуры (Enterprise Content Management - ECM) возникли в ответ на необходимость работы с неструктурированной информацией, под которой подразумеваются как традиционные офисные документы в формате Word или Excel, PDF, так и множество других типов неструктурированных данных, включая рисунки, чертежи, графики, сканированные изображения и вообще файлы любых форматов, сообщения электронной почты, сводки новостей, видео, Web-страницы и т. п. Очевидно, что в перечисленных типах данных концентрируются знания и опыт организации, и эффективность ее системы управления организационными знаниями, как и вообще успешность бизнеса, зависит от способности с максимальной полнотой использовать эту информацию.

«Управление содержанием организации» - это набор технологий, инструментов и методов, используемых для сбора, накопления, управления, хранения и доставки информации всем потребителям внутри организации. Рассмотрим основные компоненты ЕСМ (по Б. 3. Мильнеру):

1. Системы управления документами контролируют процессы создания, редактирования, публикации и архивирования документов. Их главное назначение обеспечить целостность документов и их четкую классификацию.

Системы управления документами по функциональности наиболее близки к системам управления организационными знаниями: $80 \%$ формализованных знаний компании содержится в документах (в виде текстов, графиков, схем и т. д.), кроме того, многие современные системы управления документами поддерживают процессы преобразования скрытых знаний в явные. Часто в компаниях системы управления организационными знаниями разрабатываются последовательно, начиная с внедрения

Указ. соч. 
системы управления документооборотом.

Документ - основная единица информации, и все существующие системы электронного документооборота (СЭД) посвящены хранению документа, его свойств и истории его жизни, а также, собственно, поддержанию всего жизненного цикла документа. Все СЭД содержат обязательные типовые компоненты: хранилище карточек (атрибутов) документов; хранилище документов; компоненты, осуществляющие бизнес-логику системы.

Основные компоненты, из которых складывается функциональность любой СЭД, следующие: управление документами в хранилище, поиск документов, маршрутизация и контроль исполнения, отчеты, администрирование.

2. Системы управления Web-контентом, как и системы управления документами, охватывают полный спектр работ, характерных для Интернета (создание, редактирование, публикация и архивирование контента), то есть позволяют работать с презентациями, предназначенными для определенных устройств (например, PDA, браузеры, не использующие фреймов, и т. д.), позволяют персонализировать контент для конкретного пользователя, в зависимости от времени и т. д.

3. Управление архивами - управление процессами хранения и удаления документов.

4. Управление цифровыми правами обеспечивает возможность безопасного распространения контента. Соответствующие функции определяют, какие пользователи за пределами корпоративного брандмауэра могут получать доступ к определенному контенту, кто имеет право копировать определенный контент и т. д.

5. Цель сотрудничества в области управления контентом - усовершенствование взаимодействия пользователей в рамках единого процесса. Сюда могут входить функции архивирования чатов, конференций на основе «белых досок» и т. д.

6. Функции ввода изображений необходимы, если изначально информация поступает в бумажной форме. Электронная версия - для ускорения ввода данных или в тех случаях, когда информацию надо сохранить, поскольку она может понадобиться для юридических целей или для взаимодействия с регулирующими органами.

Комплексные средства управления организащионньли знаниями: платформы и корпоративные порталь знаний. При разработке платформы управления организационными знаниями создается единая информационная среда, в рамках которой применяются различные IT-инструменты, описанные выше.

Корпоративный портал - способ собрать на одном экране всю ту информацию, которая необходима сотруднику для исполнения служебных обязанностей. При этом для доступа к ней и составляющим ее подсистемам (информационным, сервисам коллективной работы, почтовым и другим сервисам) достаточно Интернет-браузера. Каждый блок страницы портала представляет собой самостоятельное рабочее поле, на котором отображено текущее состояние того или иного пользовательского приложения, например электронной почты, каталога поступающих материалов из внешних новостных источников, календаря с пометками пользователя, каталога документов, генерируемых внутри организации, окна форума, окна, содержащего документ в обработке, и других компонентов. На страницах портала могут размещаться ссылки на часто используемые приложения и базы данных. Главная страница может быть стандартизированной, но каждый сотрудник имеет возможность самостоятельно настроить интерфейс в соответствии со своими потребностями с учетом прав доступа.

Работать с корпоративным порталом могут не только сотрудники организации, но и внешние контрагенты, получающие защищенный доступ к необходимой информации через Интернет. Корпоративный портал может выполнять функцию шлюза, 
обеспечивающего быстрый доступ ко всем применяемым в компании системам управления знаниями.

Средства организаџии совместной работы позволяют наладить взаимодействие в случаях, не поддающихся строгой формализации. Необходимость такой поддержки возникает в условиях переговорного процесса или работы творческой команды (рабочего созвездия). К программному обеспечению такого класса относятся: чаты, форумы и конференции, программные продукты позволяющие организовать online-конференцию.

\section{2. МЕТОДИЧЕСКИЕ ПОЛОЖЕНИЯ ПО УПРАВЛЕНИЮ ИНФОРМАЦИОННЫМ ПОЛЕМ ОРГАНИЗАЦИИ}

Здесь представлена система целевых показателей управления информационной инфраструктурой организации. Предложена схема оценки эффектов управления, позволяющих судить о рациональности и целесообразности внедрения предложенной модели информационной инфраструктуры с позиций теорий менеджмента и кибернетики.

Управление информационным полем организации, основанным на предложенной модели информационной инфраструктуры, должно опираться на целевые показатели, относительно которых и формируются методы управления. Показателями внешнего управления информационной инфраструктурой могут рассматриваться результаты и эффекты, которые достигаются от ее внедрения и эксплуатации и проявляются на уровне организации, ее процессов и характеристик как целостной социально-экономической системы.

Теория современного менеджмента, впрочем, как вся теория институциональной экономики, на данный момент не имеет четкого экономико-математического аппарата выражения эффективности системы управления организацией. Выдающийся теоретик институциональной теории О. E. Williamson утверждает ${ }^{1}$, что «...не стоит ожидать появления в аппарате теории менеджмента некого комплексного показателя, который бы внес количественную определенность в оценку эффективности управленческой инфраструктуры». Действительно, большинство работ по теории менеджмента предлагает оценку локальных эффектов внедрения или совершенствования системы менеджмента. О. E. Williamson предлагает рассуждения об эффективности системы менеджмента в контексте показателей надежности, интерпретированного качества, трансакционных издержек. Наиболее популярным подходом в настоящее время является показатель сокращения трансакционных издержек, подходы к количественной оценки которых развиты многими исследователями: В. Дементьевым, Я. Кузминовым, С. Малаховым, А. Олейником, Р. Нуриевым, Р. Радаевым, В. Тамбовцевым, А. Шаститко, М. Дженсеном, Р. Джоскоу, У. Меклингом, К. Ме-наром, Дж. Милгромом, Дж. Робертсом, Т. Эггертссоном. В современной теории трансакционных издержек к ним относят ${ }^{2}$ затраты организации, проявленные в прямой или косвенной форме, отнесенные на исследования и поиск информации, заключение сделок, сопровождение технологических процессов и защиту прав собственности.

${ }^{1}$ Williamson $O$. E. The economics of organization: The transaction cost approach//American Journal of Sociology. 1981. Vol. 87 2001.

2 Реym А. Л. Информационная инфраструктура рыночной экономики: теоретический аспект. СПб, 
Вопрос научной детерминированности показателей эффективности управления информационным полем организации пока также остается не решенным. Многие ученые и специалисты ${ }^{1}$ однозначно понимают, что эффекты должны проявляться на уровне организации как системы, ее отдельных составляющих, в отношении которых может быть сформирована или интерпретирована количественная оценка. Именно в этом контексте можно выделить предложенные подходы ${ }^{2}$ :

интерпретированный эффект «структурированности организационной структуры»;

поиск корреляции с формальными экономическими показателями организации как микроэкономической системы;

оценку уровня неопределенности коммуникационных связей, энтропии организации);

оценку трансакционных издержек управления;

количественную интерпретацию эффектов взаимодействия отдельных субъектов управления в информационном поле организации Исследование обозначенных подходов позволило автору сделать три вывода, носящие общенаучный характер:

1. Пока не предложено комплексного научного подхода к оценке эффектов управления информационным полем организации из-за отсутствия общего методологического базиса интерпретации количественных результатов внедрения системы менеджмента.

2. Предлагаемые методы отражают концепцию, модель или парадигму управления информационным полем организации, разработанную автором.

3. Целевые показатели управления носят локальный характер, то есть представлены как эффекты. Многие авторы выбирают наиболее значимый в рамках модели фактор, имеющий количественную интерпретацию, и используют его как показатель эффекта управления информационным полем.

Опираясь на представленные выводы, автор настоящей исследовательской работы решил сформировать и обосновать набор целевых показателей, отвечающих сформированным парадигме и модели управления информационной инфраструктурой организации. Очевидно, что факторами (инструментами) управления являются административная регламентированность и экономическая мотивированность взаимоотношений субъектов, предопределенных схемой взаимосвязей информационной инфраструктуры организации (механизмы реализации рассмотрены в п. 3.4). А задачи управления определяются аналогично целевой функции и принципам синтеза концепции информационной инфраструктуры (см. гл. 1).

Предлагаемые целевые показатели в управлении:

1. Снизить трансакционные издержки субъектов, организации на поиск информации в процессе подготовки управленческих решений.

2. Сократить расходы организации на приобретение внешней первичной (формализованные отчеты, исследования) и вторичной информации (консультанты, эксперты).

${ }^{1}$ Колмогоров А. Н. Три подхода к определению понятия «Количество информации» // Новое в жизни, науке, технике. Сер. «Математика, кибернетика». 1991. № 1; Копайгородский А. Н. Методы, модели и программные средства построения информационной инфраструктуры исследований в энергетике: автореф. ... дис. канд. техн. наук: 05.13.18. Иркутск, 2008.

${ }^{2}$ Orlikowski W. J., Robey D. Information Technology and the Structuring of the Organizations. Information Systems Research. Vol. 2. N 2. 1999; Weill P., Broadbent M. Leveraging the New Infrastructure: How Market Leaders Capitalize on Information. Boston: Harvard Business School Press, 1998; Ларичев О. И., Петровский А. $B$. Системы поддержки принятия решений. Современное состояние и перспективы их развития // Итоги науки и техники. Сер. Техническая кибернетика. Т. 21. М.: ВИНИТИ, 1987. 
3. Повысить пертинентность (управленческую чистоту) внутренней формализованной информации (база данных).

4. Увеличить качество управленческой информации за счет накопления и тиражирования знаний (неформализованной информации), основанной на внутреннем опыте, компетенции, интуиции.

Автором предлагается в качестве целевых показателей управления выбрать эффекты, которые находят свое отражение на уровне показателей организации или элементов ее информационной инфраструктуры. Исследование возможных эффектов внедрения предложенной модели (рис. 4.4), анализ возможных показателей количественной интерпретации и апробация (модели и ее эффектов) в предприятии $3 \mathrm{AO}$ «Мегастиль» (2007-2008 гг.) позволили предложить следующую структуру целевых показателей управления информационной инфраструктурой организации (табл. 4.2).

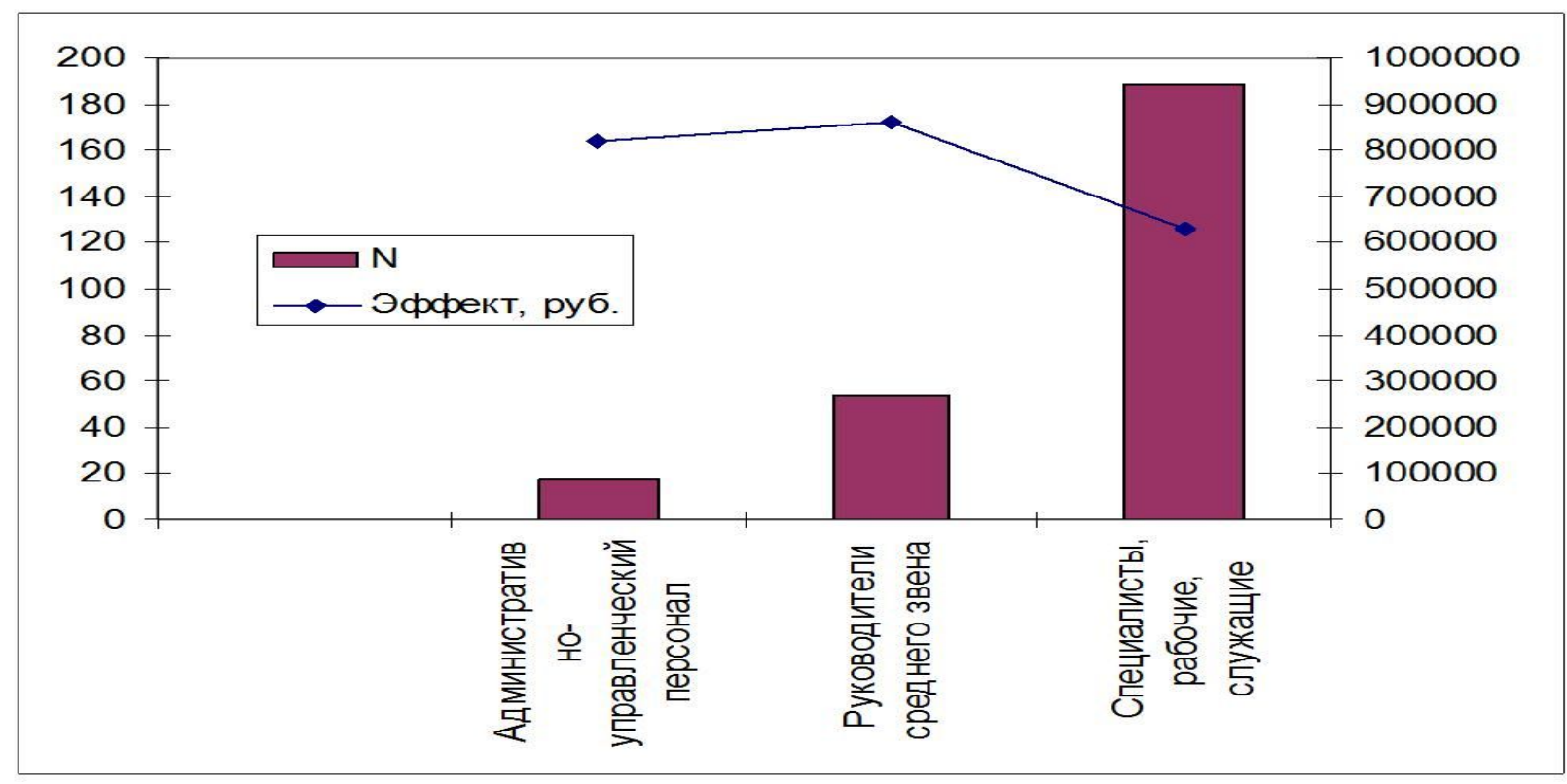

Рис. 4.4. Структура эффекта трансакционных издержек по группам специалистов организации «Мегастиль» по данным табл. 4.3

Обозначения переменных в нижеприводимых формулах количественной оценки и функциональной взаимосвязи представлены в табл. 4.2.

В 2007 г. на предприятии «Мегастиль» (производство электротехнической продукции, строительство и отделочные работы, дизайн) автор проводил комплекс консалтинговых работ, связанных с постановкой управленческого учета, системы сбалансированных показателей и организацией информационной инфраструктуры. Ситуация организации в 2007 г. была принята как стартовая -«как есть», все изменения в структуру менеджмента (в том числе в информационную инфраструктуру) были внесены в декабря 2007 -февраля 2008 г. Изменения информационного поля и системы менеджмента были произведены в соответствии с теоретической моделью, представленной в п. 3.1. Значимых изменений объемов продаж и других факторов революционного изменения объема и содержания хозяйственной и управленческой деятельности в организации в указанный период не наблюдалось. Замеры показателей организации и информационной инфраструктуры на декабрь 2007 г. и по результатам изменений в феврале 2008 г. 
составили базу для количественной оценки эффектов, демонстрируемой в настоящем параграфе как апробация.

Таблищза 4.2

Структура целевых показателей, эффектов управления информационной инфраструктурой организации

\begin{tabular}{|c|c|c|}
\hline \multirow{2}{*}{\multicolumn{3}{|c|}{$\begin{array}{lc}\text { Эффект } & \text { Содержание } \\
\text { 1. Комлексные эффекты организации } E I\end{array}$}} \\
\hline & & \\
\hline $\begin{array}{l}\text { 1.1. Эффект трансакции- } \\
\text { онных издержек, руб. }\end{array}$ & \multirow[t]{4}{*}{$\begin{array}{l}\text { Сокращение времени на поиск информации в } \\
\text { процессе подготовки управленческих решений } \\
\text { субъектами. }\end{array}$} & $T C$ \\
\hline \begin{tabular}{|l} 
Административно- \\
управленческий персонал
\end{tabular} & & $T C^{A}$ \\
\hline $\begin{array}{l}\text { Руководители среднего } \\
\text { звена }\end{array}$ & & $T C^{M}$ \\
\hline $\begin{array}{l}\text { Специалисты, рабочие, } \\
\text { служащие }\end{array}$ & & $T C^{E}$ \\
\hline \begin{tabular}{|l}
1.2. \\
эффект внешней первичной \\
информации
\end{tabular} & $\begin{array}{cccc}\text { Снижение затрат на } & \text { приобретение } \\
\text { формализованной } & \text { информации: } & \text { сведений } \\
\text { данных, исследований, отраслевых обзоров и т. п. }\end{array}$ & $C T^{P}$ \\
\hline \multicolumn{3}{|c|}{ 2. Эффекты контура формализованной управленческой информации $E^{\phi}$} \\
\hline \begin{tabular}{|cr}
2.1. & Пертинентность \\
внешней & первичной \\
информации, $\%$
\end{tabular} & $\begin{array}{l}\text { Сокращение объема информационных единиц } \\
\text { внешней первичной информации, накопленной в } \\
\text { базе данных }\end{array}$ & $P$ \\
\hline \multicolumn{3}{|c|}{$\begin{array}{l}\text { 3. Эффекты контура неформализованной управленческой информации (внедрения } \\
\text { системы менеджмента знаний) } E^{\text {нф}}\end{array}$} \\
\hline $\begin{array}{l}\text { 3.1. Эффект базы знаний, } \\
\text { \% }\end{array}$ & $\begin{array}{l}\text { Объем востребованных субъектом управления } \\
\text { информационных единиц по отношению к } \\
\text { емкости базы }\end{array}$ & $K B$ \\
\hline $\begin{array}{l}3.2 . \quad \text { Экономический } \\
\text { эффект внешней вторичной } \\
\text { информации, руб. }\end{array}$ & $\begin{array}{l}\text { Сокращение объема затрат на приобретение } \\
\text { неформализованной } \\
\text { консультантов, экспертов }\end{array}$ & $C T^{S}$ \\
\hline
\end{tabular}

Для измерения трансакционных расходов (их изменений за период 2007-2008 гг.) на предприятии «Мегастиль» было введено таймирование рабочего времени административно-управленческого персонала и самооценка (экспертный метод) для руководителей среднего звена и специалистов. Таймирование и самооценка производились два раза: до и после внедрения модели информационной инфраструктуры.

Результаты экспертизы и таймирования сопоставились со средней стоимостью рабочего времени специалистов соответствующей группы при расчете эффекта (см. табл. 4.2). В итоге был получен эффект от внедрения модели информационной инфраструктуры, оцениваемый как сокращение затрат рабочего времени на поиск информации при формировании управленческих решений сотрудниками организации. Логика расчета эффекта влияния на трансакционные расходы организации представлена в табл. 4.3. Эффект снижения трансакционных расходов организации «Мегастиль» за 2008 г. теоретически оценивается в размере 2315206 руб. 
Оценка эффекта трансакционных издержек при внедрении модели управления информационной инфраструктурой в организации «Мегастиль» в 2008 году

\begin{tabular}{|c|c|c|c|c|c|c|}
\hline \multirow[t]{2}{*}{ Категория субъектов управления } & \multirow[t]{2}{*}{$\mathrm{N}$} & \multicolumn{3}{|c|}{ T, час. } & \multirow{2}{*}{$\begin{array}{l}\text { Сp. } \\
\text { Руб. }\end{array}$} & \multirow{2}{*}{$\begin{array}{l}\text { Эффект, } \\
\text { руб. }\end{array}$} \\
\hline & & 2007 & 2008 & $07-08$ & & \\
\hline $\begin{array}{l}\text { Административно-управленческий } \\
\text { персонал }\end{array}$ & 18 & 345,6 & 268,8 & 76,8 & 593,75 & 820800 \\
\hline Руководители среднего звена & 54 & & & 56,8 & 281,25 & 862650 \\
\hline Специалисты, рабочие, служащие & 189 & & & 22,1 & 151,25 & 631756 \\
\hline Итого & & & & & & 2315206 \\
\hline
\end{tabular}

Интересен промежуточный вывод такого исследования, демонстрируемый на диаграмме (см. рис. 4.4). При сравнительно малой численности административноуправленческого состава и руководителей среднего звена организации (27 \% численности) их доля его в снижении расходов составляет 72 \%. К аналогичным выводам пришел и Д. В. Гуртов $^{1}$, рассматривающий информационную инфраструктуру как систему, ориентированную только на административный персонал организации.

Вторым показателем комплексной оценки эффекта управления информационной инфраструктурой автор предлагает ввести «экономический эффект внешней первичной информации» $\left(C T^{P}\right.$, см. табл. 4.2). Эффект имеет абсолютное выражение снижения затрат на приобретение (покупку) информации, сведений и данных, исследований, отраслевых обзоров и т. П., то есть информации определенной как формализованная внешняя первичная. Эффект достигается упорядоченностью внутренней формализованной вторичной информации в базе данных (элемент KPI), наличием поля взаимодействия и сети личных связей с субъектами управления (обмен знаниями), отсутствием дублирования закупок информации. Сетевой, прозрачный обмен информацией в организации увеличивает доступность ее для всех субъектов сети, формирует альтернативность использования информационных источников - замена внешних источников на внутренние, более пертинентные.

Эффект трансакционных расходов на поиск информации и эффект внешней первичной информации имеют одинаковое выражение - экономическое (финансовые единицы), а их сумма может быть интерпретирована как эффект управления информационной инфраструктурой (EI, см. табл. 4.2.):

$$
\mathrm{EI}=\mathrm{TC}+\mathrm{CT}^{\mathrm{P}}
$$

Функционирование модели информационной инфраструктуры реализуется на двух контурах: формализованном, управленческой информации, и неформализованном, обмена и накопления знаний. Каждый из контуров также может быть охарактеризован по проявляемым в нем эффектам. Более того, достижение показателя управления (EI) не очевидно в рамках факторов его образования, не наблюдается выраженной зависимости, так как имитационная модель определена (п. 3.2) как качественная, не параметризированная. Тем не менее, можно судить о наличии эффектов в обозначенных контурах, до определенной степени объясняющих генезис комплексного результата управления информационной инфраструктурой. Обнаружение вторичных эффектов, выявляемых в рамках контуров, также служит подтверждением положения о том, что

\footnotetext{
${ }^{1}$ Гуртов Д. В. Информационная инфраструктура: монография. М.: Изд-во РАГС, 2006.
} 
комплексный эффект достигнут именно за счет управления информационной инфраструктурой, а не вызван другими, побочными эффектами функционирования социально-экономического объединения (революционными и эволюционными эндогенными и экзогенными причинами).

Структура предложенных вторичных эффектов обусловлена свойствами модели управления, составом модуля структурирования и управления, функцией включенных в него элементов.

Эффекты контура формализованной управленческой информации ( $E^{\phi}$, табл. 4.2, рис. $4.5)$ ориентированы на достижение пертинентности внешней первичной информации.

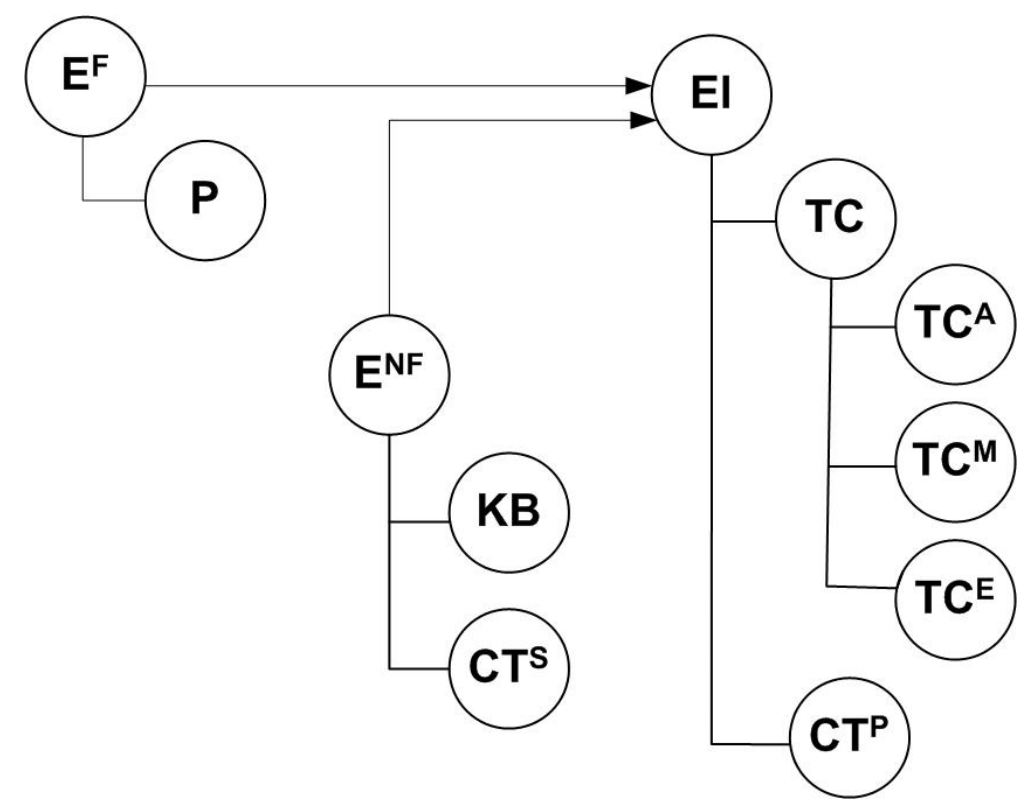

Рис. 4.5. - Структура взаимосвязи эффектов управления информационной инфраструктурой организации. Обозначения согл. табл. 4.2..

Эффект пертинентности (Р) оценивается по абсолютному выражению (сокращения) объема информационных единиц внешней первичной информации, накопленной в базе данных. Достижение эффекта реализуется управленческой деятельностью, основанной на системе сбалансированных показателей. Снижение объема свидетельствует о наличии фильтра (KPI) по отношению к внешним сетевым источникам формализованной информации, регулирующего критерия накопления внешних сведений в базе данных организации. Описанные в п. 3.3 модели информационной инфраструктуры, в том числе и прототипная «сбалансированная», считают данный фактор определяющим, характеризующим эффективность «информационной воронки». Пертинентность формализованной информации как достигнутый в результате управления информационной инфраструктурой эффект может быть оценена в абсолютном или относительном выражении:

$$
\begin{aligned}
& P=\mathrm{DB}^{\mathrm{t}+1}-\mathrm{DB}^{\mathrm{t}} \\
& \mathrm{P}=\frac{\mathrm{DB}^{\mathrm{t}+1}-\mathrm{DB}^{\mathrm{t}}}{\mathrm{DB} \mathrm{t}^{\mathrm{t}}} \times 100
\end{aligned}
$$


где $D B^{f}$ - количество учетных записей в базе данных на период измерения.

База данных - формальный электронный источник данных, поэтому оценка численности ее записей, относящихся к внешним первичным потокам (IFI), вполне может быть реализована в любой организации. В организациях, где хранение внешней первичной информации основано на бумажном документообороте, как минимум, есть электронная база данных учета единиц хранения. Поэтому списание в архив (уничтожение) бумажных единиц находит свое отражение в электронной базе и служит оценке пертинентности. Результаты расчета эффекта пертинентности информации (как и других, далее рассматриваемых показателей управления) для организации «Мегастиль» сведены в табл. 4.4). Эффект повышения пертинентности (сокращения объема) внешних первичных информационных потоков составил 12,7 \%.

Таблица 4.4

Мониторинг эффекта базы знаний предприятия «Мегастиль» в 2008 г. (обозначения по формуле (4.3))

\begin{tabular}{|c|c|c|c|c|c|c|}
\hline \multirow[t]{3}{*}{ Месяц } & \multirow[t]{3}{*}{$K \boldsymbol{K}$} & \multicolumn{5}{|c|}{$K B, \%$} \\
\hline & & \multicolumn{3}{|c|}{ По типу } & \multicolumn{2}{|c|}{ По категориям } \\
\hline & & $\begin{array}{l}\text { Электрон- } \\
\text { ный }\end{array}$ & Бумажный & АУП & PC3 & СПЦ \\
\hline 1 & 175 & 2,0 & 1,4 & 4,8 & 3,3 & 0,2 \\
\hline 2 & 267 & 3,5 & 2,3 & 5,6 & 4,5 & 0,6 \\
\hline 3 & 456 & 4,3 & 2,4 & 8,9 & 4,5 & 0,8 \\
\hline 4 & 678 & 4,6 & 4,5 & 9,3 & 4,9 & 1,2 \\
\hline 5 & 784 & 5,6 & 5,6 & 10,4 & 7,4 & 3,4 \\
\hline 6 & 987 & 12,2 & 5,6 & 11,6 & 8,9 & 5,7 \\
\hline 7 & 1876 & 22,5 & 7,2 & 11,9 & 12,9 & 8,7 \\
\hline 8 & 1933 & 25,6 & 6,7 & 12,6 & 28,0 & 7,8 \\
\hline 9 & 3455 & 34,7 & 8,9 & 17,9 & 27,9 & 8,3 \\
\hline 10 & 4425 & 37,0 & 8,4 & 29,5 & 34,5 & 9,5 \\
\hline 11 & 6576 & 49,0 & 10,1 & 37,5 & 37,5 & 8,7 \\
\hline 12 & 6988 & 54,0 & 9,4 & 45,5 & 45,6 & 11,3 \\
\hline
\end{tabular}

Эффекты контура неформализованной управленческой информации $\left(\mathrm{E}^{\mathrm{H \Phi}}\right)$ обусловлены внедрением, эксплуатацией и управлением системой менеджмента знаний организации. Управление неформализованной информацией нацелено на повышение роли прямого (личного) и опосредованного (база знаний) обмена опытом, компетенциями сотрудников в контурах управления организации. Реализация управления знаниями не может быть оценена на прямую, во-первых, в силу скрытости (имплицитности) механизмов обмена знаниями в организации от наблюдения исследователем, во-вторых, в силу качественного характера результатов такого взаимодействия. Именно поэтому нами предлагается интерпретация результатов управления неформализованными потоками информации через косвенные эффекты. В качестве таковых предлагаются синтезированные показатели: эффект базы знаний (KB) и экономический эффект внешней вторичной информации (CT $T^{S}$ см. табл. 4.2) и количественную интерпретацию для «Мегастиль» (см. табл. 4.4). 
Эффект базы знаний (KB) интерпретируется как объем востребованных субъектом управления информационных единиц по отношению к емкости базы. Логика показателя отражает интерес субъектов управления к сведениям базы знаний, внутренней вторичной информации, сформированной и интерпретированной менеджером знаний. Мониторинг показателя основан на оценке соотношения числа обращений к информационным единицам базы знаний (KR) по отношению к емкости базы знаний $(K U)$, приходящиеся на одного субъекта управления $(S N)$ организации:

$$
\mathrm{KB}^{\mathrm{t}}=\frac{\sum_{\mathrm{t}} \mathrm{KR}}{\left(\sum_{\mathrm{t}} \mathrm{KU}\right) \times S N_{t}}
$$

Показатель демонстрирует, какую часть базы знаний использует усредненный субъект управления. В организации «Мегастиль» база знаний носит смешанный характер по типу носителей информацией (бумажная документация и электронная, компьютерная). Мониторинг обращений к базе в 2008 г. велся дифференцированно по категориям субъектов управления (административно-управленческий персонал, руководители среднего звена и специалисты), его результаты представлены в табл. 4.4 и на рис 4.6.

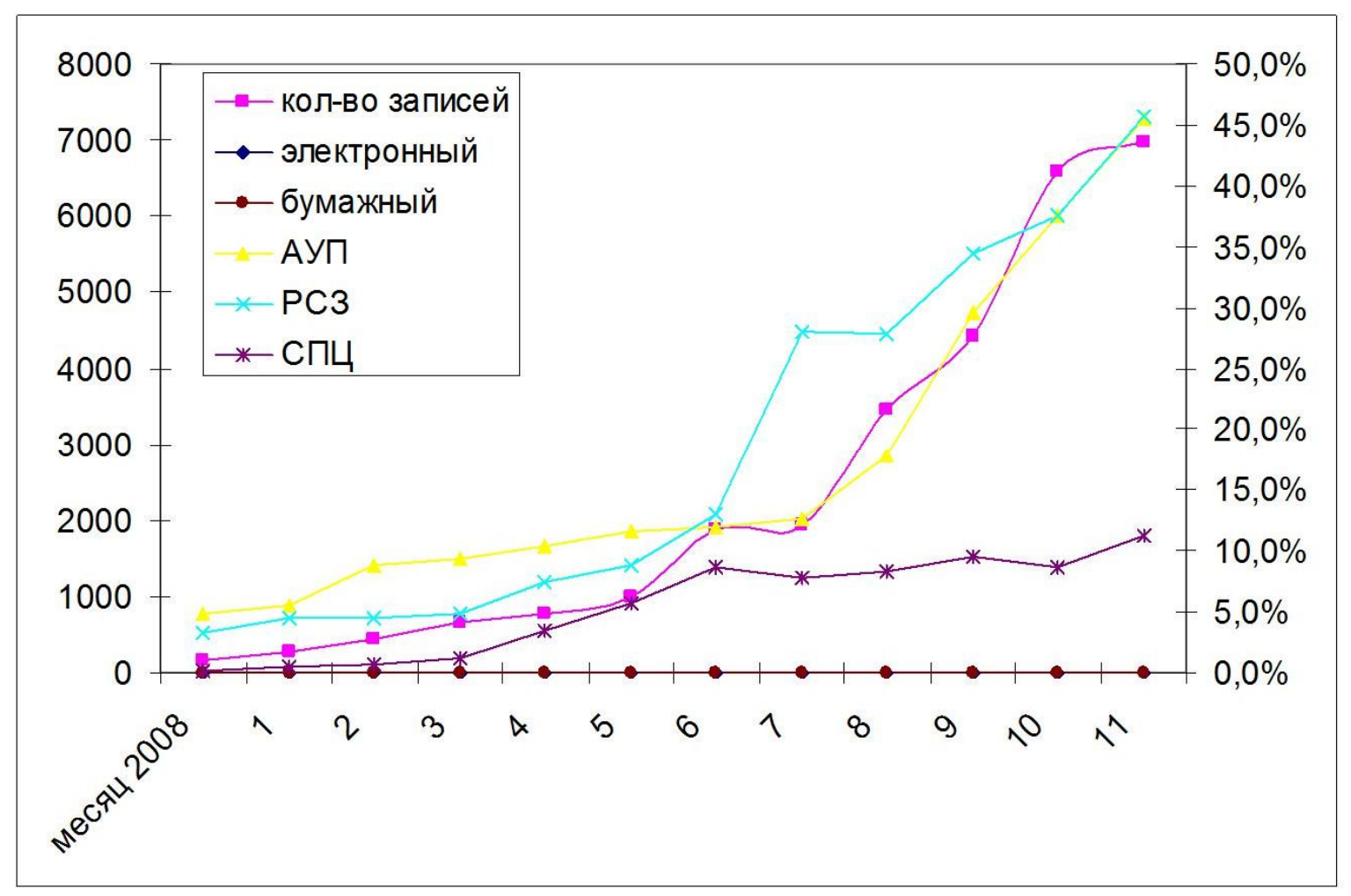

Рис. 4.6. — Мониторинг эффекта базы знаний предприятия «Мегастиль» в 2008 г.

Наблюдения и анализ показателя эффекта базы знаний в рамках заявленной детализации позволили сделать ряд важных научных выводов (очевидных при анализе данных:

1. Субъекты управления выступают и источниками сведений для базы знаний, и 
пользователями (потребителями формализованных знаний).

2. Увеличение емкости базы знаний напрямую связано с осознанием субъектами управления ее полезности в процессах принятия решений.

3. Востребованность сведений из базы знаний пропорциональна ее емкости, то есть чем больше записей, тем больше востребованность.

4. Сведения базы знаний, формализованные в электронном виде, значительно более востребованы, чем информация на бумажном носителе.

5. Управленческий персонал и руководители среднего звена являются основными потребителями и поставщиками информации базы знаний.

Данные выводы во многом совпадают с общетеоретическими представлениями менеджмента знаний. Контур неформализованной информации, контур управления знаниями, применительно к предприятию «Мегастиль», выполняет функцию, заложенную в него и определенную свойствами синтезированной сетевой модели информационной инфраструктуры. А показатель, несмотря на его внутреннюю (замкнутую на динамику) структуру и относительную форму интерпретации, удовлетворяет требованиям наблюдения эффекта управления информационной инфраструктурой. И, следовательно, может быть использован в системе управления организацией.

Второй из эффектов контура неформализованной информации носит более очевидный характер из-за его экономического содержания. Экономический эффект внешней вторичной информации $\left(C T^{S}\right)$ интерпретируется как сокращение объема затрат на приобретение услуг консультантов, экспертов. Действительно, внутри-организационное знание, личный и опосредованный обмен опытом и компетенциями должны существенно снизить интерес субъектов управления к технологически сложному и весьма затратному пути приобретения информации от внешних консультантов и экспертов. Сторонние субъекты могут предложить «совет», «знание принципов», «знание ситуации» с неопределенным качеством сведений, которые субъекту еще требуется переработать, интерпретировать в управленческое решение. «Коллеги», субъекты управления организации, могут иметь готовое решение для конкретной управленческой ситуации субъекта, что и определяет ценность прямого личностного контакта. В организации «Мегастиль» можно наблюдать проявление обмена знаниями (см. табл. 4.4 и рис. 4.6), что позволяет принять полученный для организации экономический эффект внешней вторичной информации как результат управления контуром неформализованной информации, управления информационной инфраструктурой. По отношению к 2007 г. эффект составил 93617 руб., 22,8 \% в годовом выражении.

Итак, сформулированные эффекты управления информационной инфраструктурой продемонстрированы на примере организации «Мегастиль» и могут быть представлены в сводной табл. 4.5.

Таблица 4.5

Эффекты модели управления информационной организации «Мегастиль» в 2008 г. (по отношению к 2007 г.)

инфраструктурой

\begin{tabular}{|l|l|}
\hline \multicolumn{1}{|c|}{ Эффект } & Значение \\
\hline Эффект трансакционных издержек, руб. & 2315206 \\
\hline Экономический эффект внешней первичной информации, руб. & 75300 \\
\hline Пертинентность внешней первичной информации, ед. & 43556 \\
\hline Эффект базы знаний (средний электронный), \% & 54,0 \\
\hline Экономический эффект внешней вторичной информации, руб. & 93617 \\
\hline
\end{tabular}


Эффекты управления информационной инфраструктурой, способы и методы их интерпретации могут рассматриваться как целевые показатели при интеграции сетевой модели в конкретную организацию. Заметим, что структура показателей не обусловлена экономическим типом организации, что позволяет использовать их для коммерческих, некоммерческих, государственных и других форм социально-экономических объединений.

Предложенная структура эффектов и целевых показателей управления информационной инфраструктурой организации развивает представления о методах воплощения синтезированной сетевой модели в систему менеджмента организации. Следует выделить ряд существенных научных положений, сформированных в контексте исследования целевых показателей:

1. Первичным показателем, комплексным эффектом управления информационной инфраструктурой организации определяется эффект трансакционных издержек (издержек на поиск информации).

2. При сравнительно малой численности административно-управленческого состава и руководителей среднего звена организации их доля его в снижении трансакционных расходов при внедрении моделей управления информационной инфраструктурой доминирующая (правило Парето 20:80).

3. Структура предложенных вторичных эффектов обусловлена свойствами модели управления, составом модуля структурирования и управления, функцией включенных в него элементов.

\section{3. ЭКОНОМИЧЕСКАЯ ЭФФЕКТИВНОСТЬ ИНФОРМАЦИОННОЙ ПРЕДПРИНИМАТЕЛЬСТВА ИНФРАСТРУКТУРОЙ}

УПРАВЛЕНИЯ СУБЪЕКТА

Внедрение предложенной концепции информационной инфраструктуры существенно сказывается на всех хозяйственных и управленческих процессах субъекта предпринимательства, меняет парадигму управления, корпоративную и организационную культуру взаимоотношений в субъекте предпринимательства, то есть может рассматриваться как значимая процессная новация в отношении субъекта предпринимательства, инновация системы менеджмента. Инновационный характер изменений проявляется в переходе от линейной схемы управления (и соответствующих информационных потоков) к сетевой. Увеличивается значимость горизонтальных потоков взаимодействия, регламентируется контур неформализованной информации, процесса обмена знаниями, происходит формализация и накопление сведений в базу знаний, появляется новый субъект взаимодействия - «менеджер знаний». В конечном итоге в субъекте предпринимательства формируется информационная инфраструктура: сетевое информационное поле, дающее новую структурную форму управленческих механизмов. Рассмотренные эффекты информационной инфраструктуры очевидны как результат усилий по ее внедрению и эксплуатации. Ряд эффектов имеет экономическое содержание, главным образом выражается через трансакционные издержки субъекта предпринимательства (расходы на исследования и поиск информации). Предложенные экономический результат управления информационной инфраструктурой и 
инновационный характер процесса ее внедрения позволяют рассуждать о процессе их реализации в организации как инвестиционном, то есть управление информационной инфраструктурой имеет выраженное экономическое содержание, инвестиционную составляющую. Значит возможна оценка эффективности инвестиций в формирование и управление информационным полем субъекта предпринимательства, позволяющая судить об экономической рациональности предложенной модели управления сетевой информационной инфраструктурой.

Предложенный инвестиционный характер оценки экономических результатов внедрения и эксплуатации информационной инфраструктуры предопределен задачей оценки эффективности реализации разработанной сетевой модели (см. п. 3.3). Для отражения эффективности, инвестиционной привлекательности, рациональности внедрения информационной инфраструктуры в конечном итоге вполне достаточно интерпретации результатов через показатель «окупаемости инвестиций». Показательно/ (return on investment -окупаемость инвестиций), так же известен как ЛОЛ (rate of return отношение среднего увеличения прибыли к объёму инвестиций). Показатель рассматривается как отношение экономического результата к затратам в рамках инвестиционного процесса, то есть является одной из форм выражения рентабельности инвестиций.

Применительно к процессу управления информационной инфраструктурой можно выделить соотношение экономического результата внедрения и соответствующих инвестиций, затрат. Под экономическим результатом понимается комплексный эффект, проявляемый субъектом предпринимательства при управлении информационной инфраструктурой (табл. 4.6). А затраты на достижение эффекта, согласно логике показателя ROI, могут быть выделены как сумма инвестиционных и эксплуатационных издержек информационной инфраструктуры. Соответственно, применительно к инновационному процессу реализации сетевой модели информационной инфраструктуры эффективность инвестиций на заданном временном промежутке может быть выражена следующей экономико-математической зависимостью:

$$
E=\frac{Q}{C^{i n v}+C^{\text {exe }}}
$$

Где Е - эффективность внедрения и эксплуатации информационной инфраструктуры субъекта предпринимательства на заданном временном промежутке, эффективность инвестиций в информационную инфраструктуру; $Q-$ комплексный экономический эффект, проявляемый субъектом предпринимательства при управлении информационной инфраструктурой; $\mathrm{C}^{\mathrm{INV}}$ - инвестиционные затраты (стартовые, разовые) на запуск и внедрение информационной инфраструктуры; С Ексл - эксплуатационные затраты на управление информационной инфраструктурой субъекта предпринимательства.

Экономические эффекты информационной инфраструктуры являются частью комплексных и вторичных, косвенных эффектов, проявляемых в процессе управления (см. табл. 4.6). Вполне обоснованно можно выделить эффекты, обладающие экономическим содержанием (интерпретированные в финансовом выражении) и рассматривать их как выделенную совокупность переменных. Это оправдано самой логикой построения эффектов управления (логической связанностью при дифференцированном характере интерпретации предложенной структуры эффектов. 
Структура экономических эффектов

управления

информационной инфраструктурой субъекта предпринимательства

\begin{tabular}{|c|c|c|}
\hline Эффект & Содержание & Обозначе \\
\hline $\begin{array}{l}\text { Эффект трансак- } \\
\text { ционных издержек }\end{array}$ & $\begin{array}{l}\text { Сокращение времени } \\
\begin{array}{l}\text { процессе подготовки } \\
\text { субъектами }\end{array}\end{array}$ & $T C$ \\
\hline $\begin{array}{l}\text { Экономический } \\
\text { эффект внешней } \\
\text { первичной } \\
\text { информации }\end{array}$ & $\begin{array}{l}\text { Снижение затрат на } 1 \text { приобретение } \\
\text { формализованной информации, сведений и данных, } \\
\text { исследований, отраслевых обзоров и т. п. }\end{array}$ & $C T^{P}$ \\
\hline $\begin{array}{l}\text { Экономический } \\
\text { эффект внешней } \\
\text { вторичной } \\
\text { информации }\end{array}$ & 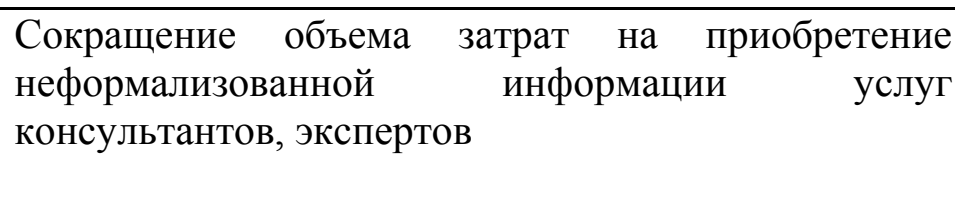 & CTS \\
\hline
\end{tabular}

Итак, экономический результат управления информационной инфраструктурой выражается как сокращение трансакционных издержек и прямых затрат на приобретение внешней первичной (формализованной) и вторичной (неформализованной) информации. Экономический эффект (4.4) раскрывается в следующем уравнении:

$$
Q=T C+C T^{P}+C T^{S}
$$

Предложенная форма исчисления может трактоваться как прямой экономический эффект внедрения информационной инфраструктуры в субъект предпринимательства. Его оценка для предприятия «Мегастиль», рассматриваемого как пример внедрения и апробации научных и прикладных результатов диссертационного исследования, представлена в табл. 4.7. Отчетливо видно, что 93 \% экономического результата приходится на трансакционные расходы и 7 \% на прямые закупки информации. Это, как это уже ранее обсуждалось, является следствием перехода на сетевую горизонтальную форму взаимоотношений субъектов управления в информационном поле субъекта предпринимательства. Впрочем, автором допускается ситуация (внедрения на другом предприятии), когда пропорция между транзакционными расходами и прямыми издержками на приобретение информации будет отличаться. Например, в обсуждении модели с представителями финансовой и банковской сфер (семинар «Современные методы и модели информационных технологий в системе предпринимательства», 23-24 февраля 2009 г.) они выразили свой интерес скорее к сокращению прямых расходов на приобретение первичной и вторичной информации, чем к эффекту снижения трансакционных расходов (которые, по их мнению, минимизированы системой регламентов внутренних бизнес процессов). 
Экономический эффект управления информационной инфраструктурой субъекта предпринимательства «Мегастиль» в 2008 г.

\begin{tabular}{|l|l|l|}
\hline Эффект & Значение, руб. & $\begin{array}{l}\text { Распределе } \\
\text { шхе }\end{array}$ \\
\hline Эффект трансакционных издержек & 2315206 & 93 \\
\hline $\begin{array}{l}\text { Экономический эффект внешней первичной } \\
\text { информации }\end{array}$ & 75300 & 3 \\
\hline $\begin{array}{l}\text { Экономический эффект внешней вторичной } \\
\text { информации }\end{array}$ & 93617 & 4 \\
\hline Итого: экономический эффект управления & 2484123 & $\mathbf{1 0 0}$ \\
\hline
\end{tabular}

Структуру инвестиционных расходов можно разделить с точки зрения их временного распределения на постоянную (стартовую) величину и переменную - пропорциональную продолжительности эксплуатационного периода. Для удобства представления и в соответствии с принятыми методологическими представлениями ${ }^{1}$ стартовые, постоянные расходы именуются инвестиционными $\left(\mathrm{C}^{\text {инв }}\right)$, а переменные расходы в последующих

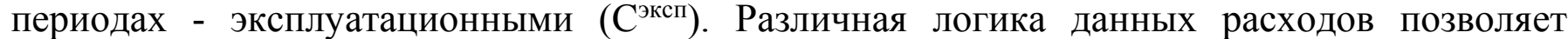
рассматривать их дифференцированно, хотя во многом (как это будет видно в дальнейшем изложении) их структура сходна.

Итак, инвестиционные расходы (Cин) предопределены в своей структуре задачей внедрения, интеграции сетевой модели информационной инфраструктуры в организацию. В соответствии с логикой модели имеем три интеграционных процесса:

1)обучение и адаптация менеджеров (субъектов управления) к новой, инновационной модели сетевых взаимоотношений (регламентированных взаимодействий в рамках системы сбалансированных показателей; работы с формализованной базой данных; регламентами внутреннего взаимодействия при принятии решений; регламентом взаимоотношений с менеджером знаний; новыми регламентами распределения рабочего времени; порядком работы и возможностями базы знаний субъекта предпринимательства);

2) интеграция менеджера знаний в организацию (знакомство с организацией, сотрудниками, целями и задачами подразделений, сущностью управленских взаимодействий, объектами управления и т. п.);

3) разработка и внедрение программно-аппаратных комплексов поддержки контуров движения формализованной и неформализованной информации (базы знаний и базы данных). В настоящее время существует вполне сформировавшийся рынок программного обеспечения для постановки баз данных и баз знаний в субъект предпринимательства. Так что вопрос сводится к выбору, покупке и адаптации персонала организации к новому программному обеспечению.

Необходимо отметить, что в систему инвестиционных затрат не включаются издержки на постановку в субъекте предпринимательской деятельности системы сбалансированных показателей - они отнесены на менеджмент субъекта предпринимательства в целом. Внедрение предложенной модели предопределяет условие принятия системы сбалансированных показателей как инструмента менеджмента

${ }^{1}$ Голъдштейн Г. Я. Стратегический инновационный менеджмент - системный фактор глобальной конкуренции // Тр. конф. «Системный анализ в проектировании и управлении». СПб ГТУ, 2001. 
организации вне зависимости от ориентированности на структурирование информационного поля субъекта предпринимательства. Наличие системы KPI в менеджменте субъекта предпринимательства скорее является условием успешности реализации предложенной сетевой модели управления информационной инфраструктурой.

Приведенные три интеграционные процесса могут быть интерпретированы как три вида расходов в инвестиционном процессе:

1)расход рабочего времени менеджеров (субъектов управления) на адаптацию в рамках модели информационной инфраструктуры. Можно учесть только затраченное оплаченное рабочее время сотрудников без альтернативной возможности использования рабочего времени (принимаем это как ограничения экономической модели);

2) оплата рабочего времени менеджера знаний на знакомство с организацией, если данный специалист является новой штатной единицей субъекта предпринимательства. Вполне удачным решением могло бы стать внедрение опытного сотрудника субъекта предпринимательства на данную должность после соответствующей переподготовки (образования). Впрочем, в этом случае будет иметь место альтернативная форма расходов на обучение (переподготовку) по специальности «менеджмент знаний»;

3) затраты на приобретение и интеграцию программно-аппаратных комплексов баз данных и баз знаний.

Приведенные три группы расходов могут быть представлены как составляющие инвестиций в реализацию модели информационной инфраструктуры в организацию. Раскрывая методы и переменные учета инвестиционных расходов, их можно представить в виде следующего экономико-математического выражения:

$$
C^{i n v}=\left(\sum_{i=1}^{n} S T_{i} \times C p_{i} \times S N_{i}\right)+S K M \times C p_{i}+C D B+C K M
$$

где $S T_{t}$ - нормативное время на обучение, интеграцию рабочего места и координационные взаимоотношения единичного субъекта управления (в рамках выделенных категорий г) в информационную инфраструктуру, ч; $C p_{t}$ - средняя норма оплаты труда субъекта управления субъекта предпринимательства (в рамках выделенных категорий г), руб.; $S N_{t}$ - число субъектов управления в субъекта предпринимательства (в рамках выделенных категорий $i)$; $S K M$-время на интеграцию специалиста «менеджер информации» в организацию (знакомство с организацией, сотрудниками, целями и задачами подразделений, сущностью управленских взаимодействий, объектами управления и т. п.), ч; $C D B$ - затраты на программно-аппаратную интеграцию, адаптацию (компьютеры, программное обеспечение, затраты на ИТ сопровождение) базы данных в информационную инфраструктуру, руб.; CKM - затраты на разработку и внедрение программно-аппаратной (компьютеры, программное обеспечение, затраты на ИТ сопровождение) составляющей базы знаний, руб.

Эксплуатационные расходы управления информационной инфраструктурой отражают четыре аналогичные (инвестиционному) процесса, отчетливо проявляемые как взаимодействие элементов системы:

1)процесс личного обмена знаниями между субъектами управления (горизонтальные сетевые взаимодействия);

2)процесс взаимодействия между субъектами управления и менеджером знаний для формализации опыта и компетенций, перенесения их в базу знаний субъекта предпринимательства; 
3)работу менеджера знаний по интерпретации и накоплению в базе знании неформализованной информации;

4) процесс поддержания в технически исправном состоянии программно-аппаратных комплексов баз данных и баз знаний.

Четыре процесса выражаются через три группы расходов, дифференцированных по внутренним принципам наблюдения переменных:

1) расходы рабочего времени менеджеров субъекта предпринимательства;

2) годовой бюджет содержания менеджера знаний в штате организации; знаний.

3) эксплуатационные затраты программно-аппаратного комплекса баз данных и

Выделенные три группы расходов могут быть представлены как составляющие эксплуатационных издержек информационной инфраструктуры субъекта предпринимательства в экономико-математической форме

$$
C^{e x e}=\left(\sum_{i=1}^{n}\left[S E_{i}+S X_{i}\right] \times C p_{i} \times S N_{i}\right)+S K M^{G}+C D B^{G}+C K M^{G}
$$

где $S X_{t}$ - рабочее время единичного субъекта управления (в рамках выделенных категорий г), затраченное на внутренние консультации с сотрудниками субъекта предпринимательства (обмен знаниями), ч; $S E_{t}$ - рабочее время единичного субъекта управления (в рамках выделенных категорий г), затраченное на работу с менеджером информации по формализации знаний (занесение в базу знаний), ч; $S K M^{G}$ - годовой бюджет содержания менеджера знаний (включая оплату рабочего времени, налоги, премии, социальные выплаты и содержание рабочего места), руб.; $C D B^{G}$ - годовые затраты на эксплуатацию программно-аппаратного комплекса базы данных, руб.; $C K M^{G}$ - годовые затраты на эксплуатацию программно-аппаратного комплекса базы знаний, руб.

Итак, раскрыты принципы исчисления экономических результатов, трактуемых как экономическая выгода (прибыль) информационной инфраструктуры, инвестиционных и эксплуатационных расходов на ее внедрение и содержание. Полную формулу эффективности реализации модели информационной инфраструктуры субъекта предпринимательства можно выразить следующим образом

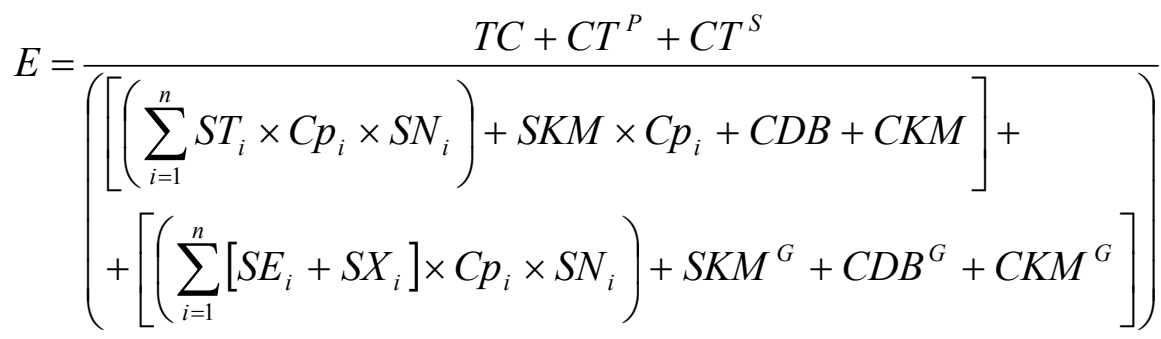

Поскольку в предложенной модели инвестиционный и эксплуатационный периоды рассматриваются как единый временной лаг затрат, возможно преобразование знаменателя к трем группам издержек: 


$$
E=\frac{T C+C T^{P}+C T^{S}}{\left[\begin{array}{l}
\left(\sum_{i=1}^{n}\left[S E_{i}+S X_{i}+S T_{i}\right] \times C p_{i} \times S N_{i}\right)+\left(S K M \times C p_{i}+S K M^{G}\right)+ \\
+\left(C D B+C K M+C D B^{G}+C K M^{G}\right)
\end{array}\right]}
$$

Первая группа выражает экономику затраченного времени менеджеров на обучение, адаптацию, сетевое взаимодействие и работу с менеджером знаний $\left(\sum_{i=1}^{n}\left[S E_{i}+S X_{i}+S T_{i}\right] \times C p_{i} \times S N_{i}\right) \quad$ за наблюдаемый период внедрения и эксплуатации информационной инфраструктуры организации. Вторая группа в аналогичном периоде оценивает издержки на включение менеджера знаний в организацию $\left(S K M C p i+S K M^{G}\right)$. И третья группа рассматривает совокупность расходов на приобретение и эксплуатацию программных комплексов баз знаний и данных $\left(C D B+C K M+C D B^{G}+C K M^{G}\right)$.

Выделение трех групп расходов и принципов их исчисления определяет корректность источников и способов получения информации об их количественном значении:

расходы и сокращения рабочего времени определяются либо выборочным таймированием рабочего времени, либо экспертной самооценкой;

прямые расходы на приобретение внешней информации, расходы на приобретение и эксплуатацию программно-аппаратных комплексов по первичной бухгалтерской документации субъекта предпринимательства;

численность и стоимость рабочего времени субъектов управления и менеджера информации - по штатным расписаниям подразделений организации.

Опираясь на модель оценки эффективности инвестиции в информационную инфраструктуру (4.8), вышеприведенные источники и способы получения исходной информации, выполнен апостериорный внедрению и первому году эксплуатации расчет для предприятия «Мегастиль». Апостериорность выражалась в том, что эффективность рассчитывалась по самому факту возникновения затрат. Предварительное планирование было затруднено, поскольку некоторые виды затрат были обнаружены только в процессе внедрения и эксплуатации информационной инфраструктуры, апробации модели. Бюджет внедрения и эксплуатации сетевой модели управления информационной инфраструктурой субъекта предпринимательства «Мегастиль» в 2008 г., представлен в табл. 4.8.

Анализ бюджета позволяет сформулировать определяющие научные выводы:

1.Эффективность инвестиций по данным апробации имеет положительный результат - 112 \%, что подтверждает корректность научного и прикладного результата экономическую рациональность сформированной модели управления информационной инфраструктуры субъекта предпринимательства.

2. Окупаемость инвестиций составляет менее одного года, что является вполне корректным и успешным показателем для процессных новаций организаций.

3. Все показатели и переменные, включенные в экономико-математическое выражение, имеют корректную интерпретацию и могут наблюдаться, фиксироваться и количественно интерпретироваться в рамках хозяйственной деятельности и учетной политики субъекта предпринимательства. 


\section{Таблица 4.8}

Бюджет (руб.) внедрения и эксплуатации сетевой модели управления информационной инфраструктурой субъекта предпринимательства «Мегастиль» в 2008 $\Gamma$.

\begin{tabular}{|c|c|c|}
\hline Показатель & $\begin{array}{l}\text { Значение, } \\
\text { руб. }\end{array}$ & $\begin{array}{l}\text { Структура, } \\
\text { распределе } \\
\text { ние затрат, } \\
\text { \% }\end{array}$ \\
\hline $\begin{array}{l}\text { Эффективность инвестиций в информационную } \\
\text { инфраструктуру }\end{array}$ & $112 \%$ & \\
\hline Экономический эффект управления & 2484123,0 & \\
\hline Итого годовых затрат на внедрение и управление & 2218132,4 & 100,0 \\
\hline Инвестиционные затраты CINV & 913688,8 & 41,2 \\
\hline $\begin{array}{l}\text { Административно-управленческий аппарат, всего затрат } \\
\text { на внедрение }\end{array}$ & 347343,8 & 15,7 \\
\hline$S T !$ & 32,5 & \\
\hline$C p$, & 593,8 & \\
\hline SN, & 18,0 & \\
\hline Руководители среднего звена, всего затрат на внедрение & 340200,0 & 15,3 \\
\hline$S T_{t}$ & 22,4 & \\
\hline$C_{P i}$ & 281,3 & \\
\hline$S N f$ & 54,0 & \\
\hline Специалисты, всего затрат на внедрение & 114345,0 & 5,2 \\
\hline$S T$, & 4,0 & \\
\hline$C_{P i}$ & 151,3 & \\
\hline$S N_{i}$ & 189,0 & \\
\hline Затраты на интеграцию менеджера знаний & 39000,0 & 1,8 \\
\hline SKM & 120,0 & \\
\hline$C p$, & 325,0 & \\
\hline Затраты на создание программно-аппаратного комплекса & 72800,0 & 3,3 \\
\hline$C D B$ & 27800,0 & 1,3 \\
\hline$c \kappa M$ & 45000,0 & 2,0 \\
\hline Эксплуатационные затраты CEXE & 1304443,6 & 58,8 \\
\hline $\begin{array}{l}\text { Административно-управленческий аппарат, всего затрат } \\
\text { при эксплуатации }\end{array}$ & 375131,3 & 16,9 \\
\hline$s x_{t}$ & 19,5 & \\
\hline$S E f$ & 15,6 & \\
\hline $\begin{array}{l}\text { Руководители среднего звена, всего затрат при } \\
\text { эксплуатации }\end{array}$ & 217350,0 & 9,8 \\
\hline$S X$ & 17,1 & \\
\hline$S E_{t}$ & 17,4 & \\
\hline Специалисты, всего затрат при эксплуатации & 202962,4 & 9,2 \\
\hline$S X_{t}$ & 5,6 & \\
\hline$S E_{t}$ & 1,5 & \\
\hline$S K M^{G}$ & 468000,0 & 21,1 \\
\hline $\begin{array}{l}\text { Затраты на эксплуатацию программно-аппаратного } \\
\text { комплекса }\end{array}$ & 41000,0 & 1,8 \\
\hline
\end{tabular}




\begin{tabular}{|l|l|l|}
\hline$C D B^{G}$ & 17600,0 & 0,8 \\
\hline$C K M^{G}$ & 23400,0 & 1,1 \\
\hline
\end{tabular}

4. Предложенная экономико-математическая логика выражения эффективности информационной инфраструктуры имеет корректную форму с точки зрения детализации включенных переменных - обнаруживаются существенные статьи расходов (процент распределения в табл. 4.8), являющихся ключевыми в формировании бюджета.

Для развития представлений об инновационном характере внедрения информационной инфраструктуры предлагается укрупненный график движения денежных средств (кэшфло) (табл. 4.9, рис. 4.7), выражающий динамику инвестиционного потока и экономического результата (эффекта).

Таблицза 4.9

Распределение во времени эффектов и затрат на управление информационной инфраструктурой организации «Мегастиль» в 2007-2008 гг., руб.

\begin{tabular}{|l|l|l|l|l|}
\hline Время & Эффект & $\begin{array}{l}\text { Инвестиционные } \\
\text { затраты }\end{array}$ & $\begin{array}{l}\text { Эксплуатацион- } \\
\text { ные затраты }\end{array}$ & Всего затрат \\
\hline 11.2007 & & 82232,0 & & 82232,0 \\
\hline 12.2007 & & 155327,1 & & 155327,1 \\
\hline 01.2008 & & 254005,5 & & 254005,5 \\
\hline 02.2008 & & 305172,0 & & 305172,0 \\
\hline 03.2008 & & 112383,7 & 27393,3 & 139777,0 \\
\hline 04.2008 & & & 28697,8 & 28697,8 \\
\hline 05.2008 & 49682,5 & & 35220,0 & 35220,0 \\
\hline 06.2008 & 106817,3 & & 41742,2 & 41742,2 \\
\hline 07.2008 & 134142,6 & & 70440,0 & 70440,0 \\
\hline 08.2008 & 156499,7 & & 96528,8 & 96528,8 \\
\hline 09.2008 & 181341,0 & & 116095,5 & 116095,5 \\
\hline 10.2008 & 248412,3 & & 193057,7 & 193057,7 \\
\hline 11.2008 & 298094,8 & & 223059,9 & 223059,9 \\
\hline 12.2008 & 459562,8 & & 215233,2 & 215233,2 \\
\hline 01.2009 & 844601,8 & & 256975,4 & 256975,4 \\
\hline Итого & 2484123,0 & 913688,75 & 1304443,6 & 2218132,4 \\
\hline
\end{tabular}

Демонстрируемое распределение соответствует классическому представлению об инновационно-инвестиционной деятельности, в частности динамическим циклам распределения инвестиционных затрат и экономических результатов. Можно наблюдать факторы инновационного цикла ${ }^{1}$ : задержку эффекта и его экспоненциальный рост; увеличение эксплуатационных затрат в процессе эксплуатации и т. п. Именно эти наблюдения подтверждают справедливость предложенного подхода к оценке эффективности внедрения информационной инфраструктуры в рамках инвестиционного менеджмента.

\footnotetext{
${ }^{1}$ Гольдштейн Г. Я. Указ. соч.
} 


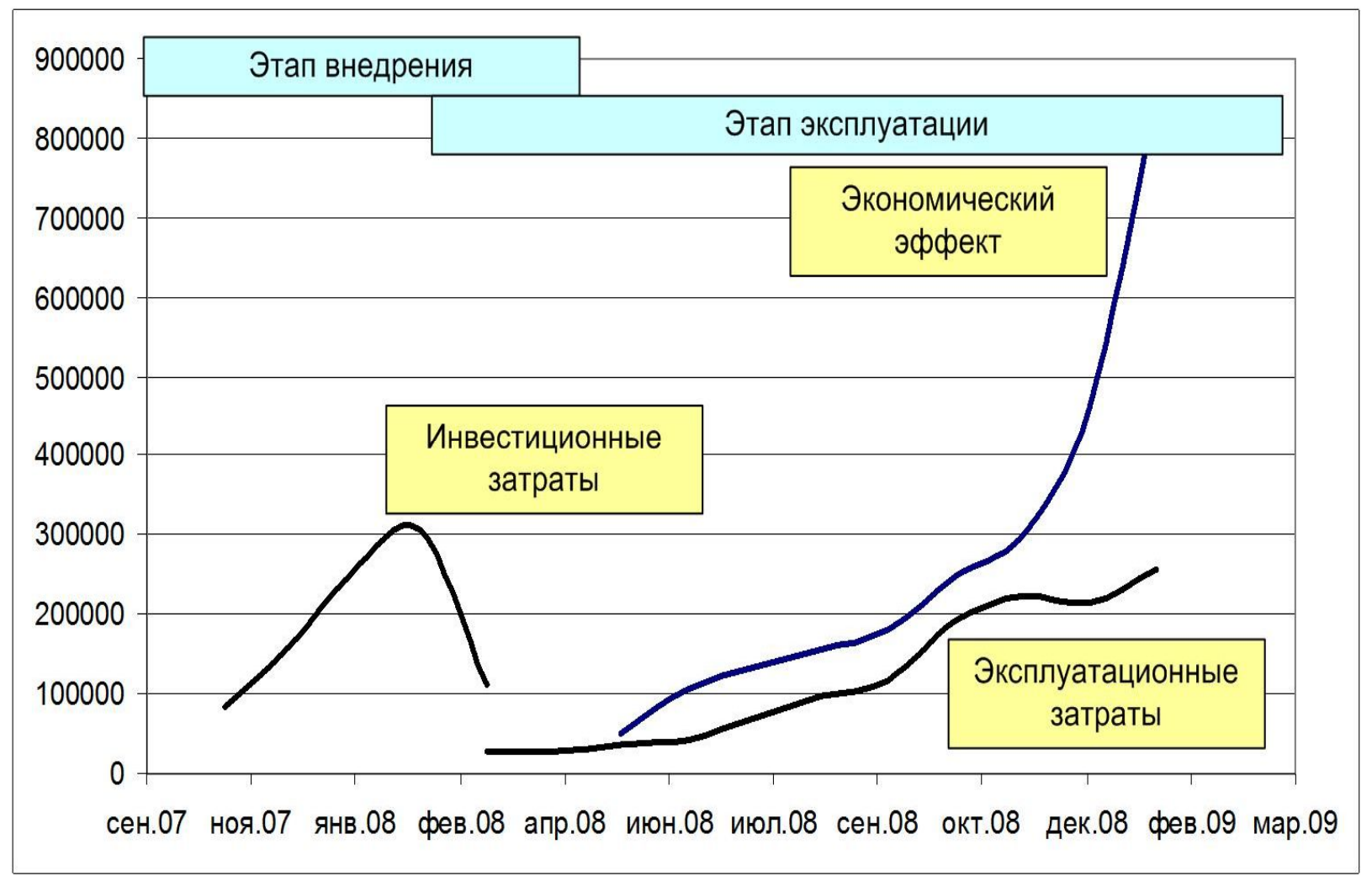

Рис. 4.7. Распределение во времени эффектов и затрат (руб.) на управление

информационной инфраструктурой субъекта предпринимательства «Мегастиль» в 2007-2008 гг. (по данным табл. 4.9)

Итак, сформирован экономико-математический базис оценки эффективности внедрения и эксплуатации информационной инфраструктуры как концепции структурирования, управления информационным пространством социальноэкономических систем. В результате апробации подтверждена экономическая целесообразность построения информационной инфраструктуры в соответствии с предложенной сетевой моделью.

\section{4. АЛГОРИТМ ФОРМИРОВАНИЯ ИНФОРМАЦИОННОЙ ИНФРАСТРУКТУРЫ}

Здесь предложен метод построения информационной инфраструктуры субъекта предпринимательской деятельности, выраженный как совокупность ключевых факторов ее реализации. Алгоритм выражает организационно-экономические принципы структурирования информационного поля системы менеджмента организации.

В данном исследовании обосновано, что наиболее актуальной концепцией онтологического структурирования информационного поля субъекта предпринимательской деятельности, отвечающей современным представлениям теорий менеджмента, организации и кибернетики, является парадигма «информационной 
инфраструктуры». Разработанная модель информационной инфраструктуры названа сетевой, что выражает предложенный принцип ее построения: управленческую сеть, взаимосвязь субъектов и объектов организации в процессах подготовки и оценки эффективности решений. Модель отличается от аналогов и прототипов содержанием научной концепции. Данный подход является новой научной точкой зрения на вопрос моделирования информационной инфраструктуры субъекта предпринимательства. Именно поэтому предложенную модель управления информационной инфраструктурой следует понимать и принимать к внедрению, в первую очередь, как совокупность взглядов, парадигму развития управленческих механизмов организации. Концептуальный характер модели обусловливает содержание методов и алгоритма внедрения модели в рамках конкретных организаций. А нацеленность предложенной модели на совершенствование системы менеджмента субъекта предпринимательства подразумевает интегративный характер изменений системы управления и информационного поля.

Представление алгоритма внедрения как некой последовательности взаимосвязанных операций в рамках предложенной модели вряд ли возможно. Во-первых, реструктуризация информационного поля происходит в субъекте предпринимательства, ведущем хозяйственную деятельность (которая не может быть «остановлена для перестройки»). Во-вторых, система менеджмента любой организации - это сложившийся «кооперативный» механизм, имеющий собственную индивидуальную структуру ценностей, идей, мотиваций, сформированных профессиональных и личностных взаимоотношений, совокупность того, что в теории современного менеджмента называют корпоративной или организационной культурой субъекта предпринимательства. И, втретьих, с объективной инертностью любой социально-экономической системы, выражающейся в отторжении любых новшеств, посягающих на сложившийся порядок вещей и ценностей (организационную культуру). Данные рассуждения не новы при постановке задачи внедрения. Любая задача, связанная с совершенствованием системы менеджмента, сталкивается с подобными ограничениями. Теория менеджмента и субъекта предпринимательства сформировали специальную предметную область, названную теорией организационных изменений, исследующую подходы и закономерности принятия и адаптации новшеств в социально-экономических системах. Большинство новых подходов в области менеджмента субъекта предпринимательства скорее могут предложить принципы внедрения, чем алгоритмические итерационные последовательности. Тем не менее, в процессе апробации модели пришлось столкнуться с некоторыми закономерностями, которые можно выделить, как определяющие последовательность интеграции информационной инфраструктуры в хозяйственную и управленческую деятельность организации.

Процесс внедрения сетевой модели управления информационной инфраструктуры, ее алгоритм (рис. 4.8), можно представить как совокупность «центров кристаллизации». Центрами кристаллизации называем выделенные критические области процесса внедрения, адаптации и принятия новой схемы взаимодействия в системе менеджмента. Критичность выражается в том, что данные элементы несут основную функциональную нагрузку в информационной инфраструктуре, их отсутствие или слабая выраженность ведут к редуцированию заявленных преимуществ сетевой модели.

Итак, первым центром кристаллизации системы менеджмента субъекта предпринимательской деятельности является «постановка системы сбалансированных показателей» (KPI). Включение системы KPI в сетевую модель продиктовано не только используемым прототипом (сбалансированная модель J. Pironti, но и самой логикой современного менеджмента субъекта предпринимательской деятельности, стремлением 
субъектов управления прийти к количественной интерпретации стратегических и оперативных целей. Н.-Г. Ольве и Ж. Ро по сути рассматривают KPI как научно новый принцип управления.

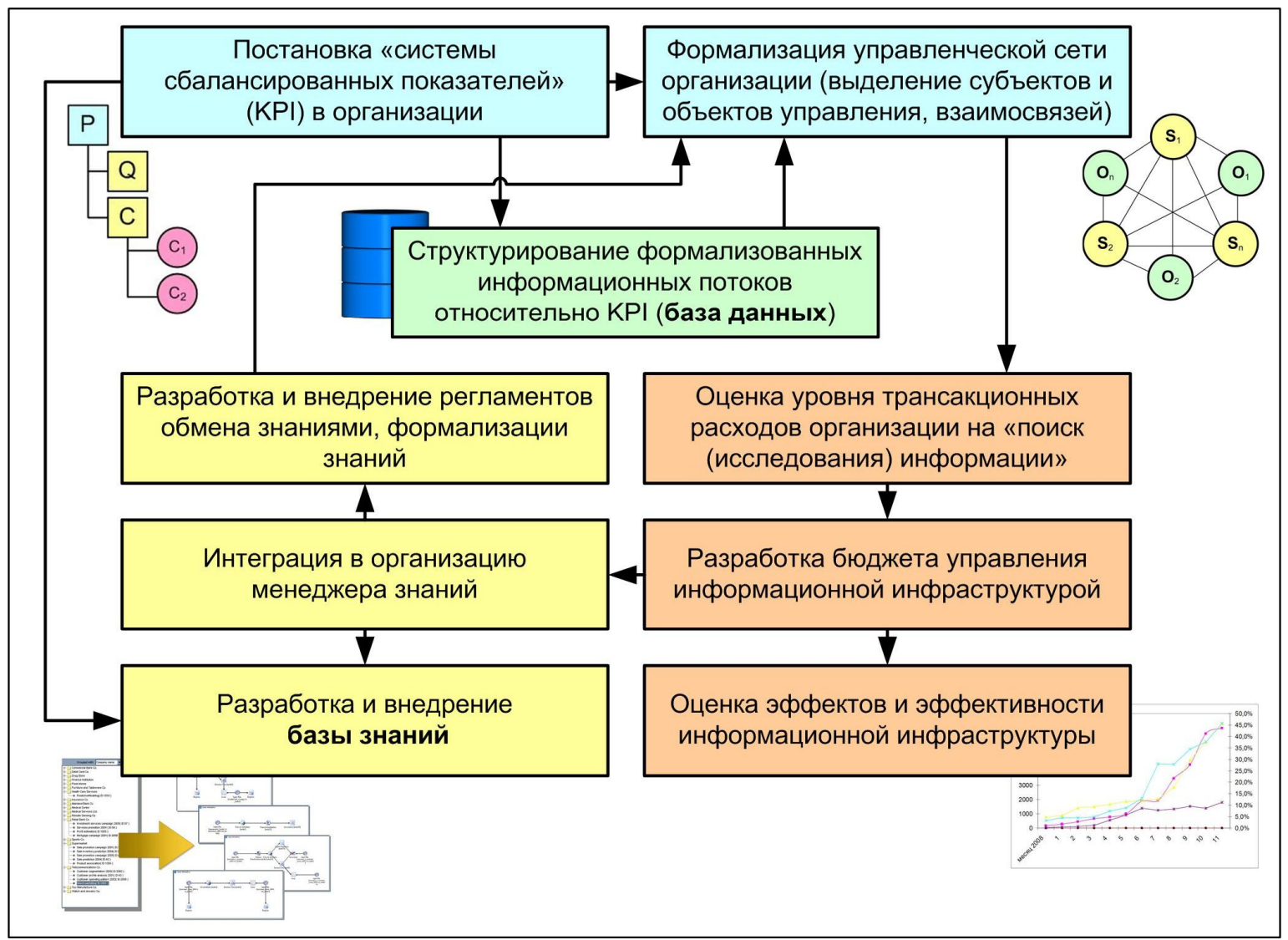

Рис. 4.8. Алгоритм формирования информационной инфраструктуры субъекта предпринимательской деятельности

«Основной принцип $K P I$, который во многом стал причиной высокой эффективности этой технологии управления - управлять можно только тем, что можно измерить. Иначе говоря, цели можно достигнуть только в том случае, если существуют поддающиеся числовому измерению показатели, говорящие управленцу, что именно нужно делать и правильно ли с точки зрения достижения цели он делает то, что делает» ${ }^{1}$.

KPI - это структурирующий принцип всех аспектов системы менеджмента: целевого состояния объектов управления, задач субъектов управления, классификационный принцип субъекта предпринимательской деятельности информационных потоков, в конечном итоге. Система сбалансированных показателей принята в модели как механизм, позволяющий повысить пертинентность управленческой информации, секвестировать паразитные и дублирующие сведения, сократить избыточный приток информации из внешних сетей. Именно поэтому внедрениеКPI в систему менеджмента организации является первичным условием, задачей на пути внедрения концепции информационной инфраструктуры.

Таблица 4.10

${ }^{1}$ Кабаков В. С, Шатрова Е. В. Стратегия предпринимательства: учеб. пособие. СПб., 1996. 
Фрагмент сетевой диаграммы «субъект-объект» субъекта предпринимательской деятельности «Мегастиль» (2007 г.), структурированной в системе сбалансированных показателей (KPI)

\begin{tabular}{|c|c|c|}
\hline KPI & \multicolumn{2}{|c|}{ Объект управления } \\
\hline $\begin{array}{l}\text { Субъекты } \\
\text { управления }\end{array}$ & $\begin{array}{ll}\text { [Оj] } & \text { Светильники } \\
\text { светодиодные } & \end{array}$ & [О $\left.{ }_{2}\right]$ Проекты освещения объекта \\
\hline $\begin{array}{ll}\text { [Sj] } & \text { Менеджер } \\
\text { продаж } & \end{array}$ & $\begin{array}{l}\text { Объем продаж } 10000 \text { ед. в } \\
\text { год }\end{array}$ & $\begin{array}{l}\text { Продать не менее } 70 \text { \% клиентам } \\
\text { услугу проектирования }\end{array}$ \\
\hline $\begin{array}{l}\left.\text { [S } \mathrm{S}_{2}\right] \text { Менеджер по } \\
\text { логистике }\end{array}$ & $\begin{array}{l}\text { Снижение себестоимости } \\
\text { комплектующих на } 9,3 \%\end{array}$ & \\
\hline $\begin{array}{l}\left.\mathrm{S}_{3}\right] \text { Коммерческий } \\
\text { директор }\end{array}$ & 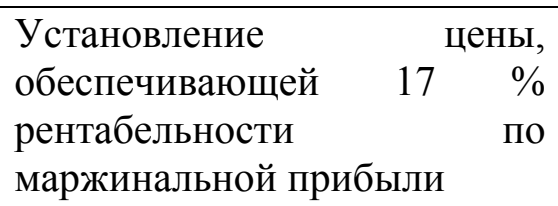 & $\begin{array}{l}\text { Увеличить объем продаж } \\
\text { дополнительных услугу в } \\
\text { проектировании на } 20 \%\end{array}$ \\
\hline $\begin{array}{ll}\left.\mathrm{S}_{4}\right] & \text { Главный } \\
\text { технолог } & \end{array}$ & 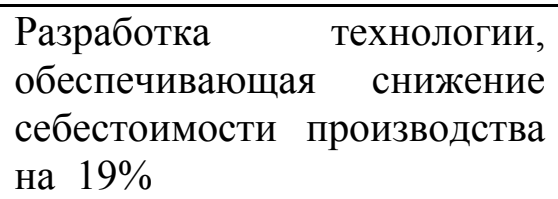 & $\begin{array}{l}\text { Сократить время проектирования } \\
\text { не менее чем на } 22 \% \text { и объем } \\
\text { аутсорсинга на } 45 \%\end{array}$ \\
\hline
\end{tabular}

Второй аспект внедрения - формализация управленческой сети субъекта предпринимательской деятельности. Формализация состоит в выделении и описании субъектов и объектов управления и системы их взаимосвязи. Как и постановку системы $K P I$, данный этап нельзя в чистом виде отнести к задачам формирования информационной инфраструктуры. Организация, стремящаяся к совершенствованию системы менеджмента, должна добиваться прозрачности и однозначности в распределении управленческих функций. Инструментом формализации может служить сетевая диаграмма ${ }^{1}$, выражающая взаимосвязи типа «субъект-объект», «субъект-субъект». При внедрении моделей, основанных на принципе KPI, характер взаимосвязи в диаграмме описывается количественным значением (табл. 4.10). Сетевая диаграмма «субъект-объект» отражает основные управленческие потоки субъекта предпринимательской деятельности, формализованные информационные единицы кибернетического типа (прямая и обратная связь контура управления). А сетевая диаграмма типа «субъект-субъект» выражает совокупность информационных оснований, формализованных и неформализованных информационных единиц, используемых в процессе подготовки решения.

Итог формализации должен иметь однозначную и прозрачную схему управленческой информации субъекта предпринимательской деятельности, количественную выраженность целевого состояния объектов управления.

Третьим элементом определяется приведение программно-аппаратного комплекса, баз данных в соответствие двум ранее обозначенным составляющим: системе

\footnotetext{
${ }^{1}$ Методические рекомендации по оценке эффективности инвестиционных едакция). Офиц. издание. М.: Экономика, 2000 (Утверждены: Министерством экономики РФ, Министерством финансов РФ, Государственным комитетом РФ по строительной, архитектурной и жилищной политике. № ВК 477 от 21.06.1999 г.).
} 
сбалансированных показателей как таксономического признака классификации информации и выраженным целевым состояниям объектов управления, управленческих потоков, отраженных в сетевых диаграммах. Данная задача является академической для методов информационных технологий. Построение базы данных в определенных условиях определяет ее статус как центра формализованной информации (внутренней и внешней). Информация, не содержащаяся в базе данных (или базе знаний), является паразитной. Категорически рассуждая, что если одномоментно удалить всю информацию со всех компьютеров организации и оставить только сервер, содержащий в электронном виде базу данных (и базу знаний), хозяйственным и управленческим процессам не должно быть нанесено ущерба. Внедрение базы данных должно рассматриваться не как система накопления сведений, а как элемент кибернетического контура управления в информационной инфраструктуре.

Четвертылм элементом определяется оценка уровня трансакционных расходов организации в издержках на поиск (исследования) информации. Подобная оценка является определяющей для выявления целесообразности совершенствования механизмов управления информационным полем субъекта предпринимательской деятельности, показателем, изменение которого рассматривается как эффективность внедрения информационной инфраструктуры (п. 4.1). По опыту замеров для ряда организаций она составляет 12-42 \% рабочего времени сотрудников, составляя 5,2-32 \% в общих затратах, что соответствует оценкам других исследователей ${ }^{1}$. Существенность данной величины делает ее серьезным основанием для совершенствования механизмов информационного взаимодействия в системе менеджмента. Оценка трансакционных расходов основана на мониторинге времени, затрачиваемом менеджерами на поиск и первичную обработку информации. Процесс мониторинга может носить сторонний характер: методы выборочного таймирования рабочего времени сотрудников ${ }^{2}$ или может строиться на менее точных, но более простых методах экспертной самооценки сотрудников субъекта предпринимательской деятельности. Например, в субъекте предпринимательской деятельности «Мега-стиль», где модель проходила апробацию, административноуправленческий аппарат компании наблюдался выборочным таймированием рабочего времени, а сотрудники среднего звена и специалисты опрашивались на основе анкеты, фрагмент которой представлен на рис. 4.9.

Пятым элементом внедрения является построение (планирование) бюджета внедрения и эксплуатации информационной инфрструктуры. Опорной точкой бюджетирования является ситуационный показатель трансакционных расходов субъекта предпринимательской деятельности (определенный выше), изменение которого (в меньшую сторону) может рассматриваться как цель внедрения модели. В п. 3.3 был рассмотрен комплекс эффектов, но как показывает опыт внедрения (п. 4.1), доминантным результатом структурирования информационного поля субъекта предпринимательской деятельности все-таки является величина трансакционных расходов - более 80 \% в итоговом показателе экономического эффекта. Можно задаться в расчете плановым снижением величины трансакционных расходов на поиск информации (см. табл. 4.8), но предсказать (в первом цикле внедрения) величину экономических эффектов в виде снижения расходов на внешнюю (формализованную и неформализованную) информацию затруднительно. Понимая линейность связи между величиной трансакционных расходов и

${ }^{1}$ Исследование факторов развития бизнеса в Российской Федерации: науч.- исследоват. отчет по данным опроса участников промышленных выставок. СПб.: НИУ ВНИЦ, 2000, 2008.

2 Свадьбина T. В. Коммуникации в организациях: учеб.-методич. пособие. Н. Новгород: Нижегородский регион, ин-т управления и экономики АПК, 1998. 
рабочим временем в планировании, можно исходить и из обратного -нормативно заданного времени на поиск и обработку информации.

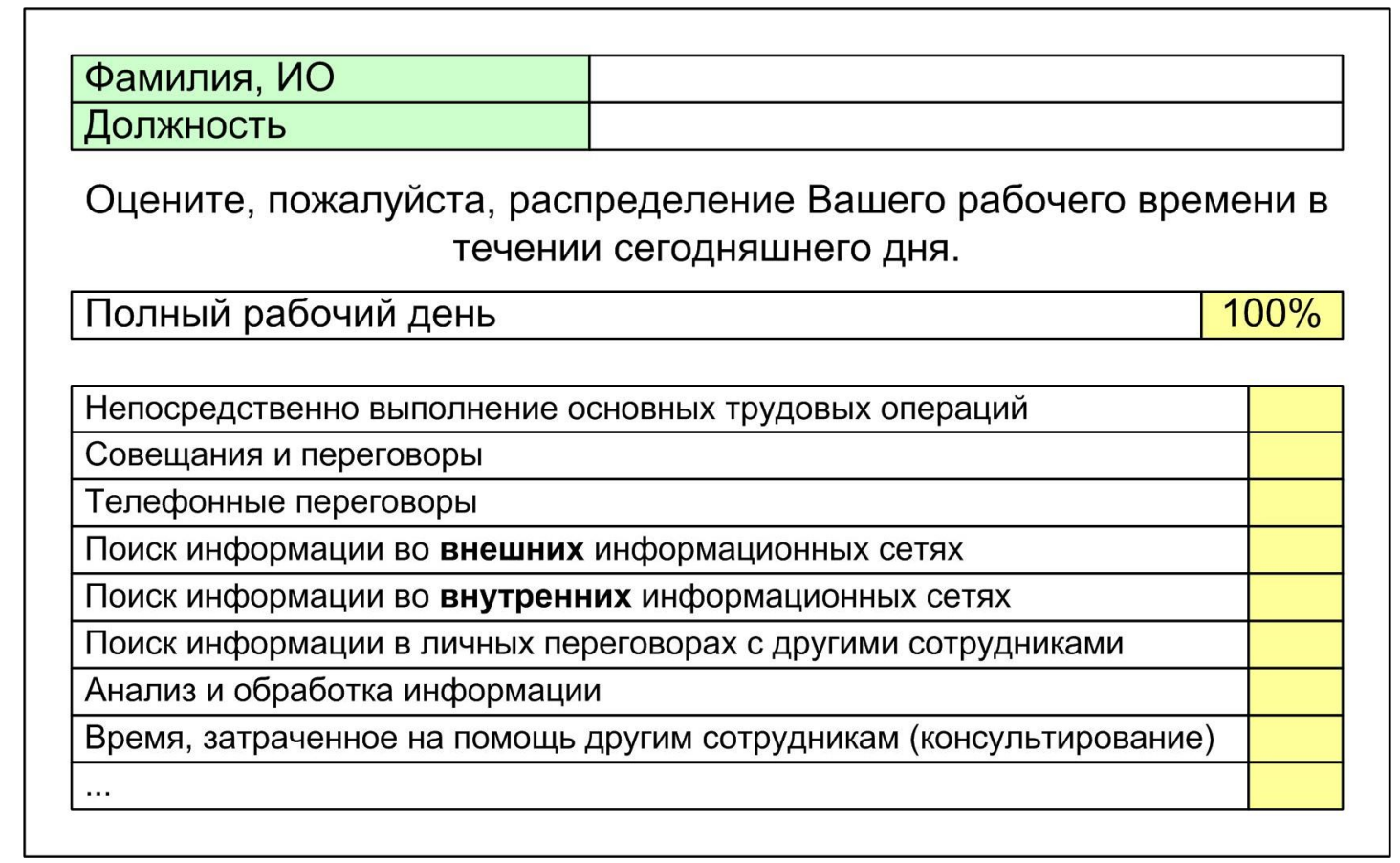

Рис. 4.9. Фрагмент самооценки расходов рабочего времени сотрудников среднего звена и специалистов «Мегастиль» в процессе мониторинга трансакционных расходов

Шестым элементом, очевидно, является интеграция менеджера знаний в структуру субъекта предпринимательской деятельности. Менеджер знаний является еще одним центром кристаллизации в модели информационной инфраструктуры, понимаемой как информационное пространство формирования и оценки управленских решений. Центром кристаллизации контура неформализованной информации, системы обмена знаниями в управленческой сети, механизмом формализации и накопления сведений в базе данных. Формально задача менеджера знаний сводится к формированию контура знаний в субъекте предпринимательской деятельности, поэтому функции его можно определить следующим образом:

1) формирование концепции знания для конкретного субъекта предпринимательской деятельности (что является знанием, каким целям служит, каким образом формализуется и т.п.);

2) обучение и пропаганда знания, обмен знаниями в организации;

3) разработка регламентов обмена знаниями в личных контактах в управленской сети и комплекс управленческих действий, направленных на контроль их исполнения;

4) разработка регламентов взаимодействия с субъектами управления (менеджерами) для формализации их опыта, компетенций и занесения в базу знания и контроль их исполнения;

5) проектирование структуры, содержания и программно-аппаратного решения базы знаний, участие в ее приобретении (покупка программного обеспечение) и внедрении;

6) формализация знания в информационные единицы для накопления в базе знаний;

7) обеспечение доступа субъектов управления к базе знаний, соответствующее обучение.

Оценка эффективности деятельности менеджера знаний может быть основана на трех объективных количественных показателях: рост числа профессиональных внутренних 
консультаций (мониторинг по таймированию или самооценке, рис. 4.9); количество сформированных записей в базе знаний; объем востребованных записей субъектами управления из базы. Заметим, что последний показатель включен в структуру эффектов управления информационной инфраструктурой (п. 3.3). Итак, с одной стороны, видны ключевой характер позиции менеджера знаний в модели информационной инфраструктуры, выраженная зависимость реализации контура знаний (неформализованной информации) от его компетенции и эффективности работы. С другой, существует определенная трудность поиска специалистов в данной области - предметная сфера, «менеджмент знаний» только формируется в последние пять лет. Именно это может стать главной трудностью на пути реализации данного фактора информационной инфраструктуры.

Cедымым фактором внедрения следует принять процесс разработки и внедрения регламентов обмена знаниями в управленческой сети и формализации знаний (трансляции опыта для интерпретации менеджером знаний в базу знаний). Несмотря на простоту декларации, при внедрении данного требования алгоритма может возникнуть (обязательно возникнет) объективная трудность. Субъекты управления не имеют естественного, выраженного желания «передавать» свои опыт и компетенцию как по причине внутренней конкуренции за рабочие места, так и по причине «потери рабочего времени на непроизводительные операции» (формулировка по опыту апробации). Разрешить данную трудность силами, компетенцией и авторитетом одного менеджера знаний невозможно. Необходимо влияние на процесс со стороны руководства компании, влияние, подкрепленное соответствующей сформированной мотивацией. По опыту решения подобной задачи в «Мегастиль» автор предлагает совокупность инструментов решения данной задачи:

1) прямые административные инструменты - требования и контроль исполнения регламентов со стороны руководства субъекта предпринимательской деятельности;

2) создание прямой финансовой заинтересованности в обмене знаниями премирование за потраченное время на консультации коллег и наполнение базы знаний. Фонд премирования передается менеджеру знаний, что повышает его управленческий статус в компании;

3) корпоративные тренинги, нацеленные на изменение корпоративной культуры «кооперативной», в которой существует моральное поощрение процесса передачи знаний;

4) система «стажерства» и «шефства» со стороны более опытных сотрудников по отношению к менее опытным и компетентным (вне зависимости от системы подчиненности).

Конечно, выбор данных инструментов во многом зависит от корпоративной культуры, но последовательное применение их должно привести к изменению корпоративной культуры, формированию контура знаний в управленческой сети субъекта предпринимательской деятельности.

Bосbмым элементом алгоритма внедрения является формирование базы знаний. Мета-функция базы знания в системе информационной инфраструктуры может быть выражена следующим определением: «семантическая модель, описывающая предметную область и позволяющая отвечать на такие вопросы из этой предметной области, ответы на которые в явном виде не присутствуют в базе» ${ }^{11}$. Действительно, роль базы знаний в информационной инфраструктуре определяется ее посредническим характером в неличных контактах в контуре неформализованной информации, возможностью передачи

${ }^{1}$ Андрейчиков А. В., Егорова И. Е,, Декатов Д. Е. Экспертные системы. Базы знаний. Инженерия знаний: учеб. пособие. Волгоград: Политехник, 2007. 
имплицитных (скрытых) сведений, опыта, компетенции, проявленной в решениях интуиции. Процесс внедрения базы знаний следует акцентировать не столько на ее разработке и наполнении менеджером знаний (это его задачи и функция), сколько на ее востребованности со стороны субъектов управления. Люди не любят осваивать что-то новое - именно эта инертность на первых этапах внедрения будет снижать ее востребованность. Необходимо разъяснение «нужности и полезности» базы, «пользы», которую она может принести в конкретной операционной деятельности субъекта управления. Опыт апробации показал, что востребованность сведений базы очень тесно связана с ее наполнением. Сначала менеджер обращается к базе знаний, чтобы посмотреть «как занесли его информацию», а уже после интересуется остальными записями. Другая трудность заключается в том, что базы знаний не содержат прямого ответа на вопрос о конкретном управленческом решении. Необходимо обучение и опыт, позволяющие субъектам управления интерпретировать содержащиеся в ней сведения в конкретный «совет по формированию решения». В решении данной задачи опять же полезными могут оказаться тренинги, ориентированные на развитие семантических навыков менеджеров, вырабатывающих навыки абстрагирования, построения аналогий.

Девятылм аспектом является постановка мониторинга эффектов и эффективности информационной инфраструктуры. Действительно, без понимания текущей ситуации трудно корректировать процесс внедрения информационной инфраструктуры. Например, предложенная в табл. 4.4 статистика экономических показателей инновационного процесса внедрения информационной инфраструктуры позволяет оценить этап внедрения, необходимость акцентов на ключевых факторах. В конкретной компании допускается введение других показателей (не предусмотренных в п. 3.3 эффектов), характеризующих состояние информационной инфраструктуры, процесса ее внедрения, обусловленных спецификой системы менеджмента.

Очень важно, чтобы показатели эффектов и эффективности внедрения информационной инфраструктуры доводились до всех сотрудников организации. Этим достигается повышение значимости менеджера знаний (что естественно увеличивает его эффективность), развивается понимание необходимости и целесообразности введенных регламентов, баз знаний, складывающейся новой информационной инфраструктуры и организационной культуры.

Итак, выделенные девять аспектов внедрения могут рассматриваться как ключевые факторы становления информационной инфраструктуры субъекта предпринимательской деятельности, построенной в соответствии с парадигмой управленческой сети. 


\section{ПРИЛОЖЕНИЯ}

\section{МЕТОДИЧЕСКИЙ ИНСТРУМЕНТАРИЙ ИССЛЕДОВАНИЯ ПРЕДПРИНИМАТЕЛЬСКОЙ МОДЕЛИ ХОЗЯЙСТВОВАНИЯ}

Для изучения характерных черт чистых предпринимательских моделей выбрано четыре коммерческих организации города Братска, для каждой из которых можно было утверждать, что структурная конфигурация организации может рассматриваться как одна из конфигураций из классификации Г. Минцберга. Этот вывод сделан на основе, анализа основных параметров проектирования организационных структур. Изучены остальные характерные черты предпринимательских моделей хозяйствования, такие как культура, персонал, стратегия и др. и сделан анализ их сочетания друг с другом в моделях различных компаний. Используемые для этого методические инструменты приведены в табл. А.1.

Таблица А.1.

Методический инструментарий исследования морфологии предпринимательской модели хозяйствования.

\begin{tabular}{|c|c|}
\hline Характерная черта модели бизнеса & Методический инструментарий \\
\hline Структурная конфигурация & $\begin{array}{l}\text { Анализ параметров дизайна - механизма координации, наиболее } \\
\text { значимая часть организации, принципы группирования, типы } \\
\text { децентрализации, степень формализации поведения }\end{array}$ \\
\hline $\begin{array}{l}\text { Организационная культура по } \\
\text { классификации Ч. Хэнди }\end{array}$ & Опрос - см. приложение В. \\
\hline $\begin{array}{l}\text { Стиль управления по классификации } \\
\text { К. Левина, стиль принятия } \\
\text { управленческих решений, общие ценности } \\
\text { на предприятии, значимость культуры }\end{array}$ & $\begin{array}{l}\text { Интервьюирование сотрудников; вопросы открытого типа, } \\
\text { например, «охарактеризуйте, пожалуйста, то, как принимаются } \\
\text { управленческие решения в вашей организации». }\end{array}$ \\
\hline $\begin{array}{l}\text { Психологический тип успешного на } \\
\text { предприятии сотрудника }\end{array}$ & Опрос по методике Майерс-Бриггс - см. приложение Б \\
\hline $\begin{array}{l}\text { Содержание стратегий и } \\
\text { стратегический процесс, временная } \\
\text { ориентация при планировании }\end{array}$ & Интервьюирование руководителей высшего звена \\
\hline $\begin{array}{c}\text { Наиболее значимые подсистемы } \\
\text { предприятия и ключевые компетенции }\end{array}$ & $\begin{array}{l}\text { Интервьюирование руководителей, изучение предприятия в } \\
\text { целом }\end{array}$ \\
\hline
\end{tabular}

Полученные результаты подтвердили правомерность расширенной классификации предпринимательской модели хозяйствования. 
Приложение Б

\section{СТАНДАРТНЫЙ ПЕРЕЧЕНЬ ВОПРОСОВ ДЛЯ ОПРЕДЕЛЕНИЯ ПСИХОЛОГИЧЕСКИХ ТИПОВ МАЙЕРС-БРИГГС СОТРУДНИКОВ ОТДЕЛА ${ }^{1}$}

Респондентам предлагалось выбрать подходящий вариант и посчитать количество баллов в каждой части.

Таблица Б.1.

Перечень вопросов для определения психологических типов

Часть 1. Экстраверсия-Интроверсия

\begin{tabular}{|c|c|}
\hline Экстраверт & Интроверт \\
\hline \multicolumn{2}{|c|}{ В гостях вы с большим удовольствием общаетесь: } \\
\hline со всеми присутствующими 1 & только с теми, кого хорошо знаете 2 \\
\hline \multicolumn{2}{|c|}{ Вам более свойственно: } \\
\hline демонстрировать свои чувства 1 & свои настоящие чувства скрывать - 2 \\
\hline \multicolumn{2}{|c|}{ В гостях на празднике: } \\
\hline вам всегда хорошо 2 & иногда скучаете 1 \\
\hline \multicolumn{2}{|c|}{ Когда предстоит встреча с незнакомыми людьми, вы это воспринимаете: } \\
\hline $\begin{array}{c}\text { как приятное или по крайней мере не обременительное } \\
1\end{array}$ & как что-то, требующее достаточно много усилий 1 \\
\hline \multicolumn{2}{|l|}{ Bac: } \\
\hline легко познать 1 & трудно познать 2 \\
\hline \multicolumn{2}{|c|}{ Среди своих вы тот, кто: } \\
\hline всегда в курсе всех дел 2 & новости узнает последним 1 \\
\hline \multicolumn{2}{|c|}{ В неприятных ситуациях вы обычно стараетесь: } \\
\hline все обратить в шутку 1 & $\begin{array}{c}\text { на следующий день думаете о том, что } \\
\text { следовало сказать } 2\end{array}$ \\
\hline \multicolumn{2}{|c|}{ По своей натуре вы: } \\
\hline общительный 2 & скорее тихий и сдержанный 2 \\
\hline \multicolumn{2}{|c|}{ В дружбе вы ищете: } \\
\hline $\begin{array}{c}\text { контакта с большим количеством разных } \\
\text { людей } 2\end{array}$ & глубокой связи с узким кругом людей 1 \\
\hline \multicolumn{2}{|c|}{ Про себя могли бы сказать, что: } \\
\hline воодушевляетесь скорее большинства людей 1 & $\begin{array}{c}\text { являетесь менее впечатлительным, чем } \\
\text { большинство } 1\end{array}$ \\
\hline \multicolumn{2}{|c|}{ Способны ли вы, если нужно: } \\
\hline $\begin{array}{c}\text { беседовать почти с каждым так долго, как это } \\
\text { нужно, без особых трудностей } 2\end{array}$ & $\begin{array}{c}\text { находите темы для разговора только с } \\
\text { определенными людьми или в определенных } \\
\text { условиях } 2\end{array}$ \\
\hline \multicolumn{2}{|c|}{ Среди своих близких вы: } \\
\hline $\begin{array}{c}\text { один из тех, кто что-то новое пробует первым } \\
-0\end{array}$ & включаетесь одним из последних 2 \\
\hline \multicolumn{2}{|c|}{ Какую роль предпочитаете для себя на празднике: } \\
\hline помочь раскручивать его ход 1 & $\begin{array}{c}\text { оставляете всех общаться на свой собственный } \\
\text { лад } 2\end{array}$ \\
\hline \multicolumn{2}{|c|}{ О ваших интересах новые знакомые получают представление: } \\
\hline скоро 1 & $\begin{array}{c}\text { только после того, как вы этих людей по- } \\
\text { настоящему узнаете } 1\end{array}$ \\
\hline \multicolumn{2}{|c|}{ В большой группе чаще всего: } \\
\hline вы кого-то кому-то представляете 2 & вас кто-то другим представляет 2 \\
\hline
\end{tabular}

${ }^{1}$ Коллисон К. Учитесь летать: практ. уроки по упр. знаниями от лучших научающихся орг. /К. Коллисон, Дж. Парселл. - М.: Ин-т комплекс. стратег. исслед., 2006.- 283 с. 


\begin{tabular}{|c|c|}
\hline $\begin{array}{c}\text { знают, что вы думаете про большинство вещей } \\
1\end{array}$ & $\begin{array}{c}\text { знают лишь то, что вы им по каким-то } \\
\text { причинам сообщили } 1\end{array}$ \\
\hline Какое слово в каждой из этих пар больше соответствует вашему духовному складу: \\
\hline праздник 1 & театр - 0 \\
\hline разговорчивый 2 & сдержанный 1 \\
\hline отважный 1 & хладнокровный 2 \\
\hline разговаривать - 0 & писать 1 \\
\hline оживленный 1 & спокойный 1 \\
\hline общительность 1 & замкнутость 1 \\
\hline
\end{tabular}

Часть 2. Сенсорика-Интуиция

\begin{tabular}{|c|c|}
\hline Сенсорный тип & Интуитивный тип \\
\hline \multicolumn{2}{|c|}{ С кем легче общаетесь? } \\
\hline с реалистами 1 & с людьми, не лишенными фантазии 2 \\
\hline \multicolumn{2}{|c|}{ Когда делаете то, что делают многие, вам более приятно: } \\
\hline действовать уже известными способами 1 & искать свои собственные методы 1 \\
\hline \multicolumn{2}{|c|}{ В художественной литературе предпочитаете: } \\
\hline $\begin{array}{c}\text { чтобы автор высказывал бы близкие вам } \\
\text { мысли } 1\end{array}$ & $\begin{array}{c}\text { вас удовлетворяют и непривычные, } \\
\text { оригинальные способы самовыражения - }\end{array}$ \\
\hline \multicolumn{2}{|c|}{ Какими людьми вы больше восхищаетесь? } \\
\hline $\begin{array}{c}\text { теми, кто так приспосабливается, что } \\
\text { становится незаметным } 1\end{array}$ & \begin{tabular}{|c} 
настолько оригинальными и \\
индивидуальными, что это бросается в глаза и \\
беспокоит их самих 2
\end{tabular} \\
\hline \multicolumn{2}{|c|}{ Что вас больше раздражает? } \\
\hline необычные теории 1 & люди, которые их не любят 1 \\
\hline \multicolumn{2}{|c|}{ Вам больше нравится: } \\
\hline традиционным способом делать добро 2 & $\begin{array}{c}\text { анализировать, нет ли еще каких-то ошибок и } \\
\text { нерешенных проблем - }\end{array}$ \\
\hline \multicolumn{2}{|c|}{ Что для человека является большей похвалой? } \\
\hline сказать, что он имеет здравый смысл 1 & сказать, что способен фантазировать 2 \\
\hline \multicolumn{2}{|c|}{ Будучи учителем, вы предпочли бы читать: } \\
\hline курс о конкретных вещах 2 & теоретический курс 2 \\
\hline \multicolumn{2}{|c|}{ Что более важно: } \\
\hline разобраться в фактическом положении 1 & увидеть возможности, которые таит ситуация - \\
\hline \multicolumn{2}{|c|}{ Кем приятнее слыть: } \\
\hline практичным человеком 2 & находчивым и изобретательным 2 \\
\hline \multicolumn{2}{|c|}{ Какого человека хотите иметь в друзьях: } \\
\hline того, кто обеими ногами стоит на земле 2 & постоянно появляется с новыми идеями 1 \\
\hline \multicolumn{2}{|c|}{ Какой жизненный стиль предпочитаете для себя: } \\
\hline общепринятый 1 & оригинальный \\
\hline \multicolumn{2}{|c|}{ Какое слово в каждой из этих пар больше соответствует вашему духовному складу: } \\
\hline реалист 2 & мечтатель - \\
\hline практика 1 & теория 2 \\
\hline строительство 2 & изобретение 1 \\
\hline правило 2 & концепция 1 \\
\hline завершенность 1 & эскиз - \\
\hline рассудительный 2 & удивительный - \\
\hline факты 2 & идеи 1 \\
\hline конкретный 1 & абстрактный 2 \\
\hline сделать 2 & изобрести - \\
\hline фундамент & шпиль 2 \\
\hline
\end{tabular}




\begin{tabular}{|c|c|}
\hline опыт & теории 2 \\
\hline конкретный признак 1 & символ - \\
\hline буквальный 1 & иносказательный 1 \\
\hline принимать 1 & изменять - \\
\hline
\end{tabular}

\section{Часть 3. Этика - Логика}

\begin{tabular}{|c|c|}
\hline \multicolumn{2}{|r|}{ Логика } \\
\hline Этический тип & Логический тип \\
\hline \multicolumn{2}{|c|}{ Что вы больше учитываете: } \\
\hline чувства других людей & или их права 2 \\
\hline \multicolumn{2}{|c|}{ У вас склонность: } \\
\hline эмоции оценивать выше, чем логику 2 & логику ценить больше, чем чувства 2 \\
\hline \multicolumn{2}{|c|}{ Что для вас является большим комплиментом: } \\
\hline это человек с настоящими чувствами 1 & он всегда благоразумен 2 \\
\hline \multicolumn{2}{|c|}{ Что является большей ошибкой: } \\
\hline быть недостаточно теплым - & проявлять слишком много теплоты 1 \\
\hline \multicolumn{2}{|c|}{ Какого руководителя вы предпочитаете: } \\
\hline всегда любезного 1 & всегда точного - \\
\hline \multicolumn{2}{|c|}{ Что происходит чаще: } \\
\hline $\begin{array}{c}\text { вы позволяете своему разуму идти за } \\
\text { чувствами } 1\end{array}$ & вашими чувствами руководит разум 1 \\
\hline \multicolumn{2}{|c|}{ Что является большим недостатком: } \\
\hline быть несопереживающим 1 & быть неблагоразумным - \\
\hline \multicolumn{2}{|c|}{ Какое слово в каждой из этих пар больше соответствует вашему духовному складу: } \\
\hline участливый - & решительный 2 \\
\hline симпатизировать 2 & анализировать 1 \\
\hline удача 1 & преимущество 1 \\
\hline некритичный 1 & критичный 1 \\
\hline трогательный 2 & убедительный 2 \\
\hline кроткий - & упорный 2 \\
\hline простить - & вытерпеть молча 2 \\
\hline кто сказал 1 & что сказал 1 \\
\hline преданный 1 & решительный 1 \\
\hline сочувствующий 1 & предусмотрительный 2 \\
\hline пощада 2 & справедливость 2 \\
\hline доверчивый - & осторожный 2 \\
\hline нежный 1 & непоколебимый 2 \\
\hline переживать 2 & думать 2 \\
\hline миротворец - & судья 2 \\
\hline согласиться - & спорить - \\
\hline
\end{tabular}

Часть 4. Рациональность - Иррациональность

\begin{tabular}{|c|c|}
\hline Рациональный тип & Иррациональный тип \\
\hline Когда вам приходится придерживаться почасового плана: \\
\hline это вам помогает 2 & это вас стесняет 2 \\
\hline Если вас в субботу утром спросить, что вы делаете в этот день: \\
\hline ответите на это достаточно точно 1 & перечислите в два раза больше возможного \\
& или задумаетесь 1 \\
\hline Свои дела вы улаживаете так, чтобы: \\
\hline не отложить на последнюю минуту 1 & охотнее всего в последнюю минуту 1 \\
\hline \multicolumn{2}{|c|}{ К чему вам труднее привыкнуть: } \\
\hline
\end{tabular}




\begin{tabular}{|c|c|}
\hline к постоянным переменам 1 & к рутине 1 \\
\hline \multicolumn{2}{|c|}{ Что вам приятнее: } \\
\hline события своей жизни планировать заранее 2 & $\begin{array}{c}\text { оставаться свободным от обязательств и } \\
\text { делать то, что предлагает случай } 1\end{array}$ \\
\hline \multicolumn{2}{|c|}{ Когда приходится начинать работу, с которой нужно справиться за неделю, вы: } \\
\hline $\begin{array}{c}\text { начинаете с того, что устанавливаете } \\
\text { отдельные этапы работы и порядок их } \\
\text { выполнения } 2\end{array}$ & бросаетесь в дело просто так 1 \\
\hline \multicolumn{2}{|c|}{ Более дельным вы оказываетесь: } \\
\hline $\begin{array}{c}\text { подчиняясь добросовестно разработанному } \\
\text { плану } 1\end{array}$ & столкнувшись с неожиданностью 2 \\
\hline \multicolumn{2}{|c|}{ Постоянный режим дня для вас: } \\
\hline удобный способ исполнения дел - & $\begin{array}{c}\text { тягостен и обременителен, даже когда } \\
\text { необходим } 2\end{array}$ \\
\hline \multicolumn{2}{|c|}{ Когда собираетесь в однодневную вылазку, вам приятнее: } \\
\hline спланировать, что и когда нужно делать 2 & ехать прямо так 2 \\
\hline \multicolumn{2}{|c|}{ Идея о том, чтобы составить список дел, которые следует выполнить в выходные: } \\
\hline может вам понравиться 1 & $\begin{array}{c}\text { не воодушевит или будет даже по-настоящему } \\
\text { удручать } 1\end{array}$ \\
\hline \multicolumn{2}{|c|}{ Свою ежедневную работу организуете так: } \\
\hline что никакой диктат не будет мешать 1 & работу под диктат вы ненавидите 1 \\
\hline \multicolumn{2}{|c|}{ Какое слово из каждой пары вам более привлекательно: } \\
\hline систематический 2 & спонтанный 2 \\
\hline планомерный 2 & непланомерный 2 \\
\hline решение 1 & импульс 2 \\
\hline пунктуальный 1 & безмятежный 1 \\
\hline аккуратность 2 & непринужденность 1 \\
\hline осторожность - & быстрота 1 \\
\hline систематичность 2 & случайность 2 \\
\hline \multicolumn{2}{|c|}{ В рутине повседневности вы находите: } \\
\hline спокойствие 1 & скуку - \\
\hline \multicolumn{2}{|c|}{ Если вам придется заняться каким-то непривычным делом, вы: } \\
\hline подготовитесь еще до того, как начинать 2 & нужное найдете в процессе самой работы 2 \\
\hline \multicolumn{2}{|c|}{ При исполнении любой работы больше надежд возлагаете : } \\
\hline на своевременное начало - & $\begin{array}{c}\text { на порыв, который вас в конце концов все } \\
\text { равно охватит } 1\end{array}$ \\
\hline \multicolumn{2}{|c|}{ Если задолго до начала срока становится известным, что конкретное в какое-то время вам придется делать: } \\
\hline $\begin{array}{c}\text { вам это приятно, так как дает возможность } \\
\text { планирования } 1\end{array}$ & $\begin{array}{c}\text { немного неприятно, как будто вы уже чем-то } \\
\text { связаны } 1\end{array}$ \\
\hline \multicolumn{2}{|c|}{ Если вас вдруг осенит какую-то мелочь купить или сделать: } \\
\hline обычно сразу записываете, чтобы не забыть 1 & позже об этом чаще всего забываете 1 \\
\hline
\end{tabular}




\section{СПИСОК ВОПРОСОВ, ИСПОЛЬЗОВАВШИЙСЯ ДЛЯ ОПРЕДЕЛЕНИЯ ТИПА КУЛЬТУРЫ ${ }^{1}$.}

Сотрудникам предлагалось выбрать подходящий вариант для действительного состояния дел в отделе и для желаемого. Ключ интерпретации ответов: 1) культура власти; 2) культура роли; 3) культура задачи; 4) культура личности.

Таблица В.1

Перечень вопросов для определения типа организационной культуры

\begin{tabular}{|c|c|c|}
\hline Вопрос & $\begin{array}{c}\text { Действитель } \\
\text { ное }\end{array}$ & $\begin{array}{c}\text { Желаемо } \\
\text { e }\end{array}$ \\
\hline 1 & 2 & 3 \\
\hline $\begin{array}{l}\text { 1. Если между сотрудниками вашей организации появятся разногласия, то: } \\
\text { 1) начнется дискуссия, в которой победит тот, кто лучше подготовлен } \\
\text { 2) стороны попросят своего шефа разобраться в их конфликте и принять решение } \\
3 \text { ) они совместно решат, что лучше для организации, и поступят соответственно } \\
\text { 4) они обсудят свои разногласия, после чего каждый поступит так, как сочтет } \\
\text { нужным }\end{array}$ & & \\
\hline $\begin{array}{l}\text { 2. } \text { Если наша организация может извлечь выгоду из определенной ситуации, но } \\
\text { нужно пойти на риск и временно отменить некоторые правила и инструкции, то: } \\
\text { 1) все решит руководство, которое и объяснит людям, что нужно сделать } \\
\text { 2) } \\
\text { мы сделаем так, только если это будет разумно и не нарушит никаких правил } \\
\text { чсе, кто имеет к этому отношение, немедленно приступят к сбору информации, } \\
\text { 4) обонять, насколько выполнима задача, и, если она выполнима мы это сделаем } \\
\text { в конце концов, никто не будет возражать, чтобы задание выполнил кто-то еще }\end{array}$ & & \\
\hline $\begin{array}{l}\text { 3. В вашей организации люди стараются работать хорошо, потому что: } \\
\text { 1) мы можем достичь чего-то, только если все будем упорно работать, а кроме } \\
\text { того, в противном случае нам придется иметь дело с боссом } \\
\text { 2) от нас ожидают, чтобы мы постоянно работали и чтобы наша работа была } \\
\text { эффективной } \\
\text { 3) задание должно быть выполнено, и мы все за это отвечаем } \\
\text { 4) задание нам интересно и стало частью нашей жизни }\end{array}$ & & \\
\hline
\end{tabular}

Продолжение табл.В.1.

\begin{tabular}{|c|c|c|}
\hline 1 & 2 & 3 \\
\hline $\begin{array}{l}4 . \text { Если кто-либо в вашей организации поссорится с шефом, то: } \\
\text { 1) он попытается навязать шефу свое мнение, но потерпит неудачу } \\
\text { 2) у нас имеется стандартная процедура, которую можно использовать, чтобы } \\
\text { прийти к решению, обязательному для обеих сторон } \\
\text { 3) все зависит от того, насколько это важно для работы; если нет, то это } \\
\text { неинтересно; если да, то коллеги проследят за тем, чтобы стороны помирились } \\
5 \text {. коллеги поговорят с ним (с ней) и помогут ему (ей) решить эту проблему, а } \\
\text { если это не сработает, то стороны продолжат конфликтовать и будут старатья } \\
\text { не общаться друг с другом (или человек начнет искать себе другую работу) }\end{array}$ & & \\
\hline $\begin{array}{l}\text { 6. Если кому-либо в вашей организации не нравится полученное задание, то } \\
\text { обычно он: } \\
\text { 1) просит повышения } \\
\text { 2) просит его заменить или говорит с начальником отдела персонала } \\
\text { 3) делает то, что требуется } \\
\text { 4) делает что-то другое или ищет другую работу }\end{array}$ & & \\
\hline $\begin{array}{l}\text { 7. Если по достижении определенной цели кто-то из вашей организации } \\
\text { лишится каких-то прав или еще как-то пострадает, то: } \\
\text { 1) все зависит от занимаемого служащим положения - с высокопоставленными } \\
\text { и влиятельными сотрудниками такого обычно не случается; как правило, это } \\
\text { происходит с мелкими сошками }\end{array}$ & & \\
\hline
\end{tabular}

$$
1 \text { Ку знецова Л.А. Раз работка управленческого }
$$

p е ше ния : у ч е б. по с о би е.- Челябинск : Челябинский государственный университет, 2001. - С. 61-65 


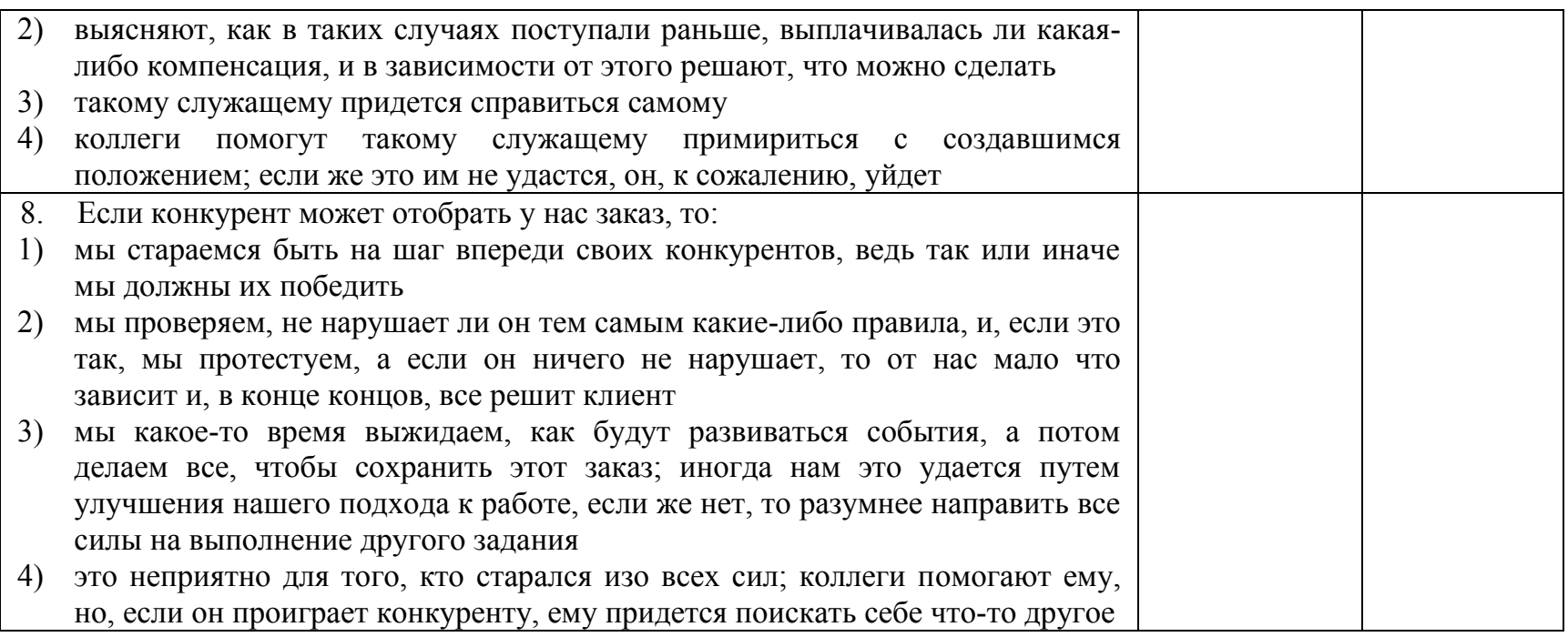

Продолжение табл. В.1.

\begin{tabular}{|c|c|c|}
\hline 1 & 2 & 3 \\
\hline $\begin{array}{l}\text { 9. Если кто-то не сможет больше справляться со своими обязанностями, то: } \\
\text { 1) он окопается, попытается укрепить свое положение и будет отбиваться } \\
\text { 2) его переведут или повысят } \\
\text { 3) задание получит кто-то другой, а этот служащий будет по возможности } \\
\text { делать что-то еще } \\
\text { 10. коллеги примирятся с создавшимся положением и помогут этому } \\
\text { служащему сделать то же самое }\end{array}$ & & \\
\hline $\begin{array}{l}\text { 11. Если ведущий сотрудник организации внезапно уходит с работы и } \\
\text { приходится искать ему замену, то: } \\
\text { 1) руководство назначает того, кого сочтет способным и компетентным } \\
\text { 2) обычно на его место назначают его заместителя, который работал здесь } \\
\text { дольше всех, хорошо себя зарекомендовал и у которого подходящее } \\
\text { образование } \\
\text { 3) ищут кого-то, кто справится с этими обязанностями и не развалит всю } \\
\text { работу } \\
\text { 4) коллеги выбирают того, у кого есть соответствующая квалификация, кто } \\
\text { может быть лидером и кому доверяют служащие }\end{array}$ & & \\
\hline $\begin{array}{l}\text { 12. Если возникнет необходимость изменения условий работы (например, } \\
\text { предложат работать в другое время), то: } \\
\text { 1) все зависит от того, что решит управляющий; если он сочтет это изменение } \\
\text { вредным, то будет ему сопротивляться; если полезным, то разрешит его } \\
\text { осуществить (в разумных пределах) } \\
\text { 2) проведут консультации; вероятно, создадут комитет, который выдвинет свое } \\
\text { предложение } \\
\text { 3) мы определим, как это изменение скажется на работе; если оно не повредит } \\
\text { делу, мы его осуществим и постараемся вместе решить возникшие проблемы } \\
\text { 4) все зависит от того, выиграют ли служащие от этого изменения; кто-то } \\
\text { выиграет и поддержит это решение, кто-то - нет }\end{array}$ & & \\
\hline
\end{tabular}


Приложение Г.

\section{ФОРМИРОВАНИЕ ССУОЗ КАК ИНСТРУМЕНТ ПОВЫШЕНИЯ КОНКУРЕНТОСПОСОБНОСТИ СТРУКТУРЫ УПРАВЛЕНИЯ БРАТСКИМ АЛЮМИНИЕВЫМ ЗАВОДОМ}

Братский алюминиевый завод (БрАЗ) - это одна из крупнейших мировых компаний по производству алюминия, основанная в 1966-м году. БрАЗ входит в состав Объединенной компании «Российский алюминий» (UC Rusal), которая является лидером алюминиевой отрасли. Продукция холдинга экспортируется клиентам в 70 странах мира. На долю компании приходится 12,5\% мирового рынка алюминия и 16\% глинозема. Выручка «РУСАЛа» в 2006м году составила \$8,18 млрд. (в 2005 году - \$6,1 млрд.). Чистая прибыль в 2004 году составила $\$ 1,06$ млрд. В 2005 году компания произвела 3,9 млн. тонн глинозема и 2,7 млн. тонн алюминия. РУСАЛ владеет 98,6\% акций БрАЗа.

БрАЗ выпускает следующие виды продукции:

- $\quad$ алюминий высокой чистоты в чушках марок А995-А95;

- $\quad$ алюминий технической чистоты в чушках (слитках);

- слитки алюминиевые и алюминиевые сплавы: слитки плоские для проката из алюминия технической чистоты, алюминиевых сплавов марок АМг2 и АМг3.

Братский алюминиевый завод производит, в настоящее время, около $30 \%$ российского и $4 \%$ мирового алюминия. В 2008-м году компанией было выпущено 1 млн. тонн алюминия. За все время работы БрАЗа на его мощностях получено свыше 30 млн. тонн алюминия. Завод сертифицирован на соответствие стандартам ISO 9001, ISO 14001, OHSAS 18001. На заводе работает около 5000 человек. БрАЗ расположен вблизи Братской ГЭС и потребляет около $75 \%$ всей производимой станцией электроэнергии. Свыше 90\% продукции завода идет на экспорт, основными странами-экспортерами продукции БрАЗа являются Великобритания, Япония, США и Италия. На внутрироссийском рынке реализуется менее $10 \%$ выпускаемого на заводе алюминия. Основными российским потребителями являются ВАЗ, ГАЗ, металлургические комбинаты в Липецке, Магнитогорске, Ступино, Красноярске и на Урале.

Завод работает по технологии Содерберга. В 2001 году БрАЗ перешел на технологию "полусухого" анода в качестве промежуточного этапа. С 2005 года все 25 корпусов электролиза БрАЗа работают на более эффективной и экологически чистой технологии "сухого" анода. Благодаря реализации экологических программ с 2000 года объемы выбросов на БрАЗе удалось сократить на 27\%. Ежегодно на экологические проекты расходуется в среднем около 200 млн. рублей. На БрАЗе ведутся работы по минимизации отходов производства, большая их часть вновь вовлекается в производство. Сейчас на предприятии перерабатывается более $60 \%$ всех отходов.

В настоящее время реализуется проект крупной модернизации завода. Инвестиции первого этапа (завершится в 2011 году) - около 350 млн. долл., В 16 корпусах планируется установить 64 новых электролизера, что позволит увеличить выпуск алюминия более чем на 100 тыс. т. В результате модернизации все электролизеры будут оснащены системами автоматической подачи глинозема. Кроме этого, в компании будут установлены 24 сухие газоочистные установки, которые обеспечивают максимальный технически достижимый уровень улавливания фторидов. Ожидается снижение валовых выбросов загрязняющих веществ на 40\%. На втором этапе планируется усовершенствование конструкции электролизеров и переход от технологии «сухого» анода на технологию «коллоидного» анода.

Для выявления типа используемой предпринимательской модели хозяйствования мы провели всесторонний анализ объекта исследования по всем составляющим предпринимательской модели бизнеса. 


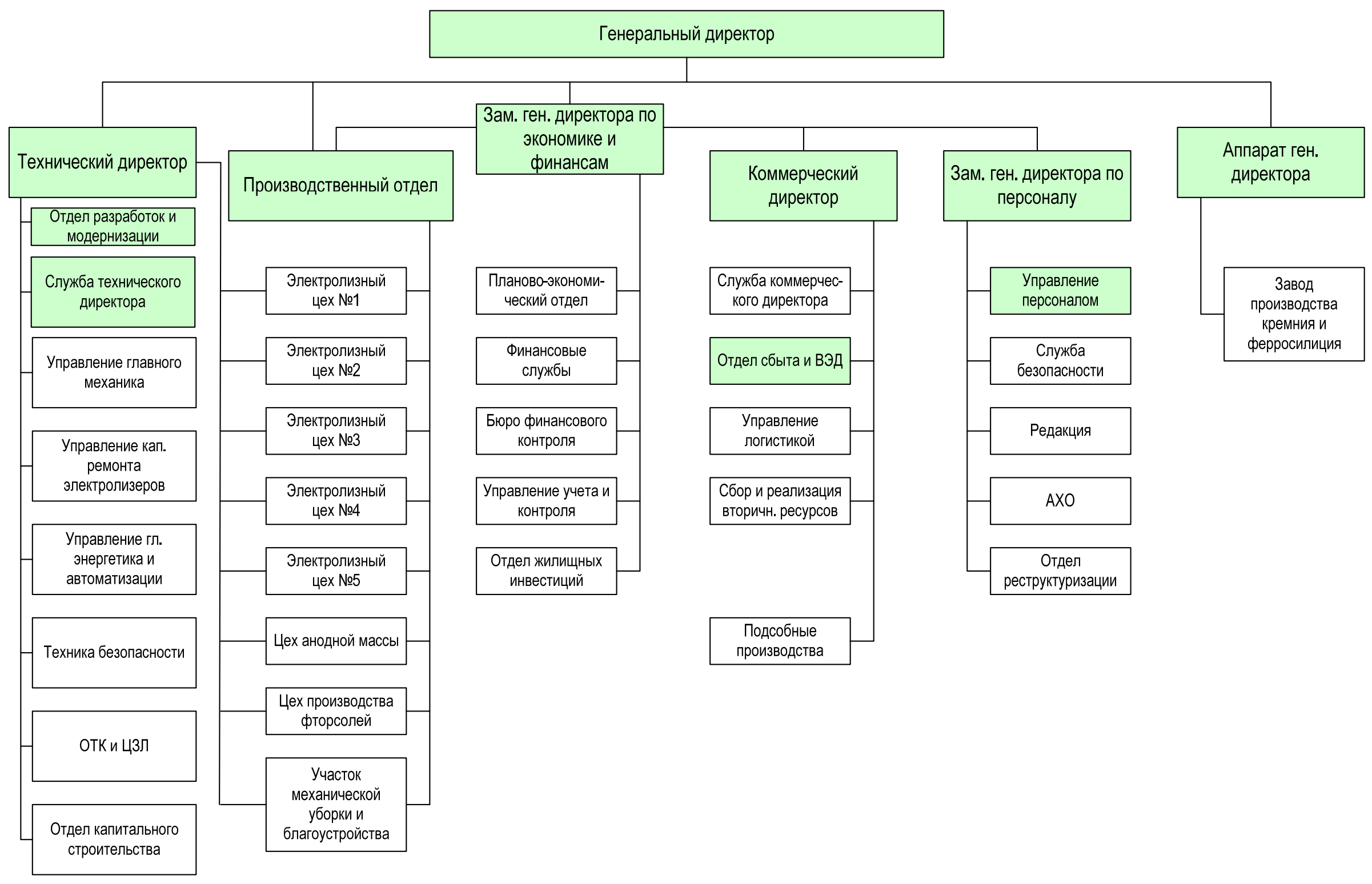

Рисунок Г.1. - Организационная структура Братского алюминиевого завода 
При исследовании морфологии предпринимательства для анализа каждой составляющей модели мы использовали соответствующую методику диагностирования, которая указана ниже, вместе со сделанными нами выводами:

- Стратегия БрАЗ (результаты интервьюирования руководителей высшего звена). Общая стратегия стратегия роста; рыночная стратегия - стратегия лидерства по издержкам; конкурентная - защита лидирующей позиции наряду с ограниченным наступлением; стратегия внутреннего развития - модернизация производства (повышение производительности, снижение объемов вредных выбросов). Стратегия разрабатывается высшим руководством, после чего детализируется аналитиками и спускается до нижних уровней организационной иерархии.

- Ключевые компетенции (то же) - низкий уровень издержек за счет эффекта масштаба.

- Структура (анализ должностных инструкций и положений об отделах, опрос отдельных сотрудников): механизм координации - стандартизация процесса, децентрализация - ограниченная вертикальная, принцип группирования большинства подразделений - функциональный, механизмы взаимодействия - менеджерыинтеграторы и специальные группы и комитеты. Таким образом, конфигурация по классификации Г. Минцберга механистическая бюрократия. Основные подразделения компании представлены на рисунке Г.1.

- Система бизнес-процессов (изучение построенной карты бизнес-процессов, обработка экспертных мнений). Разработанная карта бизнес-процессов позволила определить основные процессы, реализуемые в компании, а также их владельцев. На основании обработки экспертных суждений (полученных посредством опроса по методу Дельфи) методом анализа иерархий был составлен рейтинг бизнес-процессов - по их вкладу в конечный результат.

Это позволило определить перечень подразделений, создание ССУОЗ в которых является особенно актуальным (табл. Г.1.). В табл. 2. представлена содержательная характеристика основных функций, реализуемых каждым из ключевых подразделений.

Таблица Г.1. - Рейтинг подразделений БрАЗа по их вкладу в конечный результат (с точки зрения создания и эффективного управления организационными знаниями, с учетом частоты реализации того или иного процесса; составлен на основе опроса экспертов)

\begin{tabular}{|c|c|c|}
\hline Бизнес-процесс & Владелец процесса & Группа рейтинга \\
\hline Разработка стратегии & Директорат & \multirow{5}{*}{$\begin{array}{l}\text { Категория А - максимальный } \\
\text { вклад в конечный результат } \\
\text { (весовые коэффициенты в } \\
\text { сумме составляют 0,67) }\end{array}$} \\
\hline Стандартизация процесса труда & Отдел технического директора & \\
\hline $\begin{array}{l}\text { Модернизация оборудования и } \\
\text { перепроектирование } \\
\text { операционного процесса }\end{array}$ & Отдел разработок и модернизации & \\
\hline Развитие сети деловых контактов & Отдел сбыта и ВЭД & \\
\hline $\begin{array}{l}\text { Контроль за реализацией } \\
\text { операционного процесса }\end{array}$ & Производственный отдел & \\
\hline $\begin{array}{l}\text { Реализация операционного } \\
\text { процесса }\end{array}$ & Производственные подразделения & \multirow{6}{*}{$\begin{array}{l}\text { Категория В - средний вклад } \\
\text { в конечный результат } \\
\text { (весовые коэффициенты в } \\
\text { сумме составляют 0,23) }\end{array}$} \\
\hline $\begin{array}{l}\text { Контроль за соблюдением } \\
\text { стандартов процессов труда }\end{array}$ & Отдел технического контроля & \\
\hline $\begin{array}{l}\text { Контроль качества сырья и } \\
\text { сплавов }\end{array}$ & Центральная заводская лаборатория & \\
\hline $\begin{array}{l}\text { Обеспечение бесперебойного } \\
\text { функционирования } \\
\text { энергетического хозяйства }\end{array}$ & Управление энергетики и автоматизации & \\
\hline $\begin{array}{l}\text { Стимулирование персонала, } \\
\text { планирование карьеры }\end{array}$ & Отдел управления персоналом & \\
\hline $\begin{array}{l}\text { Обеспечение бесперебойности } \\
\text { работы оборудования }\end{array}$ & Управление главного механика & \\
\hline $\begin{array}{l}\text { Контроль за соблюдением техники } \\
\text { безопасности }\end{array}$ & Отдел техники безопасности & \multirow{6}{*}{$\begin{array}{l}\text { Категория. С - } \\
\text { незначительный вклад в } \\
\text { конечный результат (весовые } \\
\text { коэффициенты в сумме } \\
\text { составляют 0,10) }\end{array}$} \\
\hline $\begin{array}{l}\text { Планирование закупок и др. } \\
\text { транспортных потоков }\end{array}$ & Отдел логистики & \\
\hline Ремонт электролизеров & Управление ремонта электролизеров & \\
\hline $\begin{array}{l}\text { Функционирование финансово- } \\
\text { экономической системы }\end{array}$ & $\begin{array}{l}\text { Службы директора по экономике и } \\
\text { финансам }\end{array}$ & \\
\hline $\begin{array}{l}\text { Планирование капитального } \\
\text { строительства }\end{array}$ & Отдел капитального строительства & \\
\hline $\begin{array}{l}\text { Планирование и реализация } \\
\text { изменений в организационной }\end{array}$ & Отдел реструктуризации & \\
\hline
\end{tabular}


Распределение ролей по реализации элементов процесса мыследеятельности между ключевыми подразделениями

\begin{tabular}{|l|c|c|}
\hline \multicolumn{1}{|c|}{ Подразделение } & Часть структурной конфигурации & $\begin{array}{c}\text { Реализуемый элемент процесса } \\
\text { мыследеятельности }\end{array}$ \\
\hline Директорат & стратегическая вершина & рефлексия, мышление \\
\hline $\begin{array}{l}\text { Отдел техничес-кого } \\
\text { директора }\end{array}$ & техноструктура & ресение \\
\hline $\begin{array}{l}\text { Производственный } \\
\text { отдел }\end{array}$ & срединная линия \\
\hline $\begin{array}{l}\text { Отдел разработокение и } \\
\text { модернизации }\end{array}$ & $\begin{array}{c}\text { вспомогательное } \\
\text { Отдел сбыта и ВЭД }\end{array}$ & подразделение/техноструктура \\
\hline
\end{tabular}

Ключевые подразделения относятся к следующим частям структуры компании и реализуют следующие элементы процесса мыследеятельности. Для исследования социально-психологического типа сотрудников указанных подразделений мы использовали опросник Майерс-Бриггс (список заданных вопросов - в приложении А). Получен следующий результат. В директорате и отделе технического директора преобладают личности типа ENTJ (экстраверты, интуитивные, мыслительные, рациональные); в отделе сбыта и ВЭД - личности типа ESTP (экстраверты, сенсорные, мыслительные, иррациональные); в отделе управления персоналом - личности типа ISFP (интроверты, сенсорные, чувствующие, иррациональные).

- Типы культуры также определялись индивидуально для каждого выбранного подразделения. Выяснилось (список вопросов - в приложении), что в директорате действительной культурой является культура роли, а желаемой - культура задачи; в отделах технического директора и сбыта и ВЭД - желаемая и действительная культуры совпадают - культура роли; в отделе же управления персоналом действительной является культура задачи, а желаемой - культура личности.

Проведенный анализ морфологии предпринимательской деятельности Братского алюминиевого завода свидетельствует о соответствии предпринимательской модели хозяйствования его ситуационным факторам и позволяет перейти к проектированию системы создания и эффективного управления организационными знаниями компании и разработанные на этой основе методы проектирования ССУОЗ направленной на повышение конкурентоспособности структур управления БрАЗом.

Рассмотрим, как распределяются роли по реализации отдельных элементов процесса мыследеятельности БрАЗа среди различных его подразделений. Стратегическая вершина (директорат) реализует «чистое мышление», разрабатывая стратегию развития завода (которая не подразумевает серьезных изменений предпринимательской модели хозяйствования; по большей части, периодически происходит небольшая коррекция заданного ранее курса развития; основной приоритет в этой стратегии - крупный проект модернизации заводского оборудования). Существующая производственная система исправно функционирует благодаря постоянной работе отдела технического директора, разрабатывающего весь комплекс регламентов производственного процесса, т.е. это подразделение отвечает за «замещение». За реализацию этого же элемента отвечает планово-экономический отдел, планируя рутинную деятельность завода, а также реализацию специальных проектов.

Элемент «действие» выполняется сотрудниками производственных подразделений, чье поведение достаточно жестко регламентируется стандартами процесса и контролируется менеджерами срединной линии (числятся в производственном отделе). Вследствие такого сильного ограничения свободы возможность оказывать влияние своей деятельностью на конечный результат практически отсутствует. Элементы «рефлексия», «коммуникация» и «отнесение» реализуются менеджерами срединных и низовых звеньев. «Рефлексия» подразумевает контроль и осмысление в непредвиденных ситуациях. Если менеджер имеет возможность самостоятельно принять решение - он его принимает и реализует, внося, таким образом, тактические коррективы в производственный процесс; если же возможность принять решение самостоятельно отсутствует, менеджер собирает информацию о ситуации («коммуникация»), определяет субъекта, способного разрешить проблемную ситуацию (обычно это представитель стратегической вершины, после принятия решения которого начинается процесс замещения, т.е. конкретизации его «абстрактного» решения с учетом нюансов практической реализации, затем оно реализуется и т.д.) и передает ему всю информацию о ситуации.

Реализации различных элементов полного цикла мыследеятельности способствуют в той или иной мере многочисленные вспомогательные подразделения. В некоторых случаях, эти подразделения настолько самостоятельны, что их процесс мыследеятельности очень часто связан с общекорпоративным. Все это говорит о том, что отношения внутри этих подразделений неконкурентные, но между подразделениями отношения вполне конкурентные.

Для определения существующих проблем в сфере создания и эффективного управления организационными знаниями и движения информации мы провели подробное интервьюирование представителей каждого ключевого подразделения. Была выявлена следующая проблематика. 
1. Сдержанность при обмене информацией и знаниями. Эта проблема характерна для всех исследуемых подразделений, но особенно это касается директорат и отдела разработок. Межличностные взаимоотношения достаточно враждебны, стиль руководства таков, что возникает показательная конкуренция между различными сотрудниками. Это препятствует обмену знаниями и информацией, т.к. каждый сотрудник считает, что, скрывая их, он укрепляет свою значимость.

2. Дублирование информационных потоков, независимый сбор одной и той же информации различными подразделения и даже представителями одного и того же подразделения (директорат). Информационные потоки не структурированы, информация «живет своей жизнью». Из-за этого возникают слишком большие затраты времени на сбор информации. Часто сотрудники не знают, к кому можно обратиться за релевантной информацией или знаниями (особенно это касается отдела управления персоналом, т.к. представители этого подразделения по большей части плохо знакомы с технологией производственного процесса).

3. Не сохраняется опыт решения проблем. Процесс решения проблем характеризуется бессистемностью, спонтанностью, откладываниями и затягиванием сроков. Проблема особенно актуальна для менеджеров срединной линии и аналитиков (отдел технического директора).

4. Слабая организационная культура: общий дух безынициативности и чрезмерный функционализм (выражается в отсутствии толерантности и объективного отношения к представителям других функциональных подразделений), безынициативность при реализации организационных изменений, частые затягивания проектов (производственный отдел). Причем касается это тех подразделений, которые в первую очередь должны проявлять инициативу - отдел разработок и директорат.

Очевидно, что охарактеризованные проблемы являются системными и охватывают всю подсистему создания и эффективного управления организационными знаниями и информационными потоками. Это, безусловно отражается не только на эффективности функционирования подразделений завода, но их конкурентоспособности. Нами разработан план мероприятий по развитию ССУОЗ завода, направленной на повышение конкурентных возможностей системы управления предполагающую реализацию 2-х основных этапов. Первый этап реализован, в настоящее время (октябрь 2009 года) начинается реализация второго этапа. На первом этапе была сформирована ССУОЗ завода в ключевых подразделениях. Для формирования системы использовался, в основном, инструментарий персонализации. Предполагается, что на втором этапе представители ключевых подразделений разработают и реализуют проект формирования ССУОЗ большинства оставшихся подразделений (вклад которых в общий результат деятельности значительный).

Ниже представлено описание основных элементов первого этапа программы по формированию ССУОЗ.

1. Для координации реализации программы в организационную структуру введена позиция менеджера отвечающего за создание и эффективное управление организационными знаниями.

2. Усилена организационная культура (см.\$4.4) посредством проведения соответствующих тренингов. Вся программа тренингов была рассчитана на 1,5 месяца и реализовалась в 2 этапа. Программа мероприятий включала в себя 8 часов лекционных занятий, посвященных основам системного мышления и вопросам формирования сильной корпоративной культуры и духа открытости (на первом этапе). Кроме того, программа предполагала прохождение каждым сотрудником двух наборов интенсивных тренингов по 16 часов каждый. На первом этапе работники формировали навыки открытого взаимодействия в процессе совместного решения проблем, устраняли блоки, препятствующие ведению конструктивного диалога в процессе совместного разрешения проблемных ситуаций. Группы были сформированы таким образом, чтобы вместе занимались люди, чаще всего взаимодействующие друг с другом в процессе работы. Вторая часть программы (реализована после трехнедельного перерыва) была направлена на закрепление выработанных навыков и индивидуальное решение проблем в этой области. Между первой и второй частью программы проводились индивидуальные консультации. Группа преподавателей - 4 тренера из привлеченного консалтингового центра и 2 психолога. Обучение прошли 47 сотрудников административно-управленческого персонала. Бюджет программы составил 430 тыс. рублей.

3. Изменен стиль управления директора завода - осуществлен переход к демократичному стилю. Разработана и реализована индивидуальная программа обучения директора завода (теоретическая подготовка и решение деловых кейсов). Работал 1 коучер совместно с менеджером завода по созданию и эффективному управлению организационными знаниями. Длительность программы - 1,5 месяца, бюджет - 30 тыс. рублей.

4. Разработана карта знаний, справочник экспертов, документально зафиксированы и доведены до сведения инженерно-технических работников задействованных на первом этапе подразделений завода, основные направления информационных потоков. Программа включала в себя следующие работы:

- предварительный сбор сведений посредством анкетирования;

- обработка результатов, разработка детальной анкеты;

- обработка, выделение основных очагов создания знаний, инновационной активности, информационных потоков, определение критериев присвоения сотруднику статуса эксперта;

- разработка и утверждение комплекта документации;

- $\quad$ назначение ответственных за обновление документов.

5. Актуализация системы регламентов, т.е. более четкое распределение полномочий и ответственности. Анализ показывает, что структура управления компанией в целом позволяет достигнуть поставленных целей; проблема состоит не в типе структуры, а в том, как она воплощается в жизнь: ответственность была распылена, отсутствовала дисциплина. В связи с этим была переработана система должностных инструкций, положений об отделах; введена система штрафов 
за нарушение трудовой дисциплины. Кроме того, потребовалась разработка более эффективной системы стимулирования персонала. За решение этих задач отвечал отдел управления персоналом.

Как указывалось ранее, в $\S 2.2$, формирование ССУОЗ оказывает непосредственное воздействие на конкурентоспособность продукции. Эти положения схематически представлены на рис. Г.2.

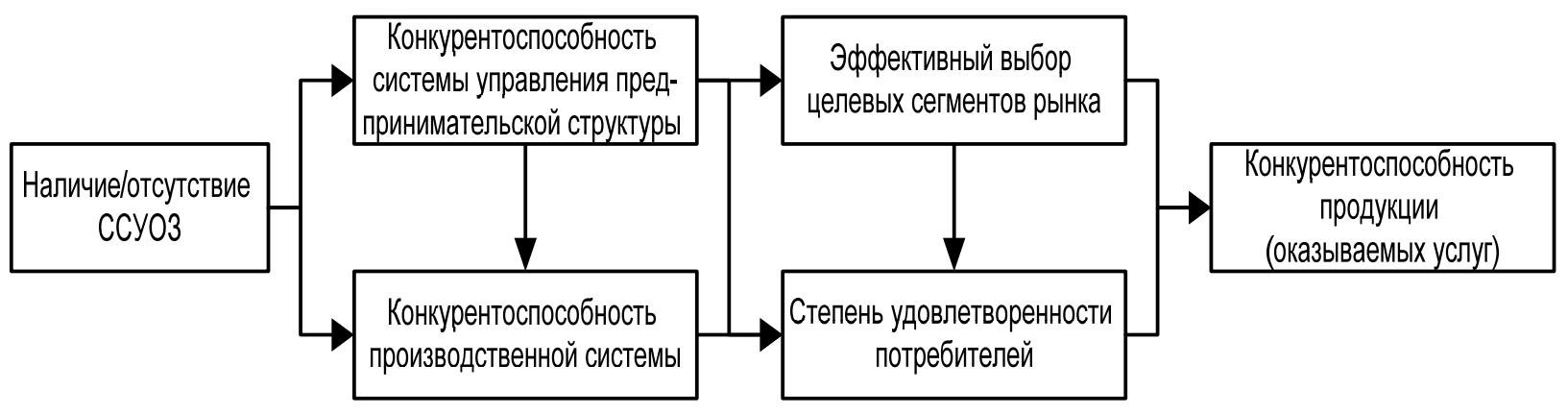

Рисунок Г.2.- Влияние наличия или отсутствия ССУОЗ на конкурентоспособность продукции

Вследствие отсутствия информации о конкурентах, при изучении влияния формирования ССУОЗ БрАЗа на конкурентоспособность системы управления компанией мы ограничились анализом динамики показателей конкурентоспособности системы управления (которая достаточно иллюстрирует влияние наличия или отсутствия ССУОЗ на конкурентоспособность системы управления предпринимательского формирования) в сравнении с эталонными значениями.

В начале реализации программы, нами совместно с представителем руководства завода был определен перечень показателей, каждый из которых мог бы отражать снижение конкурентоспособности системы управления БрАЗом из-за наличия соответствующих проблем в сфере создания и управления знаниями и движения информации. После этого, используя метод Дельфи, получены экспертные суждения об относительной значимости каждого из показателей, которые нормализованы с использованием метода анализа иерархий Т.Саати. Результаты этой работы представлены в табл. Г.3.

После определения относительной значимости показателей конкурентоспособности системы управления компанией, экспертам предложено определить эталонные значения. Для определения влияния сформированной ССУОЗ на конкурентоспособность системы управления БрАЗом были проведены измерения фактических значений показателей до реализации программы по формированию ССУОЗ и после (табл. 4.).

Таблица Г.3. - Показатели конкурентоспособности системы управления БрАЗом

\begin{tabular}{|c|c|c|}
\hline Наименование & Описание & $\begin{array}{c}\text { Относительная } \\
\text { значимость }\end{array}$ \\
\hline $\begin{array}{l}\text { 1. Месячные средние затраты времени на } \\
\text { поиск информации, минут }\end{array}$ & $\begin{array}{c}\text { месячные затраты времени на сбор и поиск } \\
\text { информации }\end{array}$ & 0,322 \\
\hline $\begin{array}{l}\text { 2. Месячные затраты времени на } \\
\text { деструктивные конфликты, минут }\end{array}$ & $\begin{array}{c}\text { учитывались только значительные конфликты, } \\
\text { которые задерживали работу }\end{array}$ & 0,281 \\
\hline $\begin{array}{l}\text { 3. Эффективность взаимодействия (оценка } \\
\text { в баллах) }\end{array}$ & $\begin{array}{l}\text { средняя субъективная оценка, } 19 \text { экспертов, } \\
\text { которые опрашивались по отдельности }\end{array}$ & 0,160 \\
\hline $\begin{array}{l}\text { 4. Количество предложенных } \\
\text { сотрудниками новых идей (за месяц) }\end{array}$ & $\begin{array}{c}\text { учитывались только значимые идеи, которые могли } \\
\text { привести к повышению эффективности } \\
\text { функционирования завода } \\
\end{array}$ & 0,144 \\
\hline $\begin{array}{l}\text { 5. Средняя оценка эффективности стиля } \\
\text { руководства директора подчиненными } \\
\text { (оценка в баллах) }\end{array}$ & $\begin{array}{c}\text { анонимный опрос (с согласия директора) } \\
8 \text { сотрудников, непосредственно } \\
\text { взаимодействующих в работе с директором }\end{array}$ & 0,093 \\
\hline
\end{tabular}

Таблица Г.4.- Эталонные и фактические значения показателей конкурентоспособности системы управления БрАЗом

\begin{tabular}{|l|c|c|c|}
\hline \multicolumn{1}{|c|}{ Наименование } & $\begin{array}{c}\text { Фактическое } \\
\text { значение до } \\
\text { формирования } \\
\text { ССУОЗ (апрель } \\
\text { 2008) }\end{array}$ & $\begin{array}{c}\text { Фактическое } \\
\text { значение после } \\
\text { формирования } \\
\text { ССУО3 } \\
\text { (март 2009) }\end{array}$ & $\begin{array}{c}\text { Эталонное } \\
\text { значение }\end{array}$ \\
\hline $\begin{array}{l}\text { 1. Месячные средние затраты времени на поиск } \\
\text { информации, минут }\end{array}$ & $120-180$ & $50-60$ & $<30$ \\
\hline $\begin{array}{l}\text { 2. Месячные затраты времени на деструктивные } \\
\text { конфликты, минут }\end{array}$ & 350 & 120 & $<60$ \\
\hline 3. Эффективность взаимодействия (оценка в баллах) & 2,7 & 3,1 & 5 \\
\hline 4. Количество предложенных сотрудниками новых & 3 & 29 & $>80$ \\
\hline
\end{tabular}


Из таблицы Г.4 очевидна положительная динамика всех анализируемых показателей конкурентоспособности системы управления БрАЗом. Рассчитаем комплексный показатель конкурентоспособности системы управления компанией по формуле:

$$
I_{c y}=\sum_{j=1}^{k} \gamma_{j} E_{j} / E_{j э m}^{u p}+\sum_{j=1}^{k} \gamma_{j} E_{j э m}^{\text {down }} / E_{j}
$$

где: $k$ - количество показателей эффективности;

$\gamma_{j}$ - коэффициент значимости показателя эффективности;

$E_{j}, E_{j э m}$ - частные показатели эффективности системы управления, фактическое и эталонное значения.

Фактическое значение индекса конкурентоспособности системы управления до формирования ССУОЗ на БрАЗе составляло:

$$
I_{c y}^{2008}=0,322 \cdot \frac{30}{150}+0,281 \cdot \frac{60}{350}+0,160 \cdot \frac{2,7}{5}+0,144 \cdot \frac{3}{80}+0,093 \cdot \frac{2,2}{5}=0.245
$$

Фактическое значение индекса конкурентоспособности системы управления после формирования ССУОЗ на БрАЗе составляло:

$$
I_{c y}^{2009}=0,322 \cdot \frac{30}{55}+0,281 \cdot \frac{60}{120}+0,160 \cdot \frac{3,1}{5}+0,144 \cdot \frac{29}{80}+0,093 \cdot \frac{3,3}{5}=0.529
$$

Таким образом, проведенный анализ показывает рост конкурентоспособности системы управления Братским алюминиевым заводом вследствие формирования на заводе ССУОЗ. Количественный расчет подтверждается и отзывами опрашиваемых сотрудников. Вероятно, самое главное, чего удалось достигнуть - это значительный рост конкурентных возможностей структурных подразделений за счёт сплоченности коллективов подразделений и развитии конкурентных отношений между подразделениями БрАЗа. 